EDITORIAL

Sarah Moura

HANS JONAS E A FRAGILIDADE DE DEUS: O ELEMENTO TEOLÓGICO DA RESPONSABILIDADE ÉTICA ANTROPOCÓSMICA

Alexandre Marques Cabral

LIBERDADE NOS NÍVEIS PRIMITIVOS DA VIDA NA FILOSOFIA DE HANS JONAS

Bruno Henrique do Rosario Xavier

MAQUINISMO E FILOSOFIA: O NASCIMENTO DA QUESTÃO DA TÉCNICA

Eduardo Ramalho Rotstein

PRINCÍPIO RESPONSABILIDADE E POLÍTICA DO DECRESCIMENTO: APROXIMAÇÕES E CONVERGÊNCIAS

Eleandro de Souza Cabral;

Mario Sergio Cunha Alencastro

SER COMO FIM IMANENTE: A ÉTICA DA RESPONSABILIDADE DE HANS JONAS

Gabriel Prado Rodrigues

SOBRE A CONSISTÊNCIA INTERNA DA ÉTICA DE HANS JONAS

Guilherme T. M. Schettini

CAMINHOS E DESCAMINHOS ENTRE O PRINCÍPIO DA RESPONSABILIDADE E O ÜBERMENSCH

José Jaime da Silva

TÉCNICA E NIILISMO: A URGÊNCIA DE UMA NOVA ÉTICA EM HANS JONAS

José Carlos Moreira

MATÉRIA E ESPÍRITO NA COSMOLOGIA JONASIANA

Lilian S. Godoy Fonseca 
OS CAMINHOS CRUZADOS ENTRE ÉTICA E METAFÍSICA NO CONCEITO DE RESPONSABILIDADE

Luciano Gomes Brazil

POSSÍVEL CONTRIBUIÇÃO DA PRAXIS AO DESAFIO DA ECOLOGIA

Maria do Carmo Bettencourt de Faria

MORTE CEREBRAL E O ENIGMA DA MORTE

Maria Luiza de Castilho Anciens

O PRINCÍPIO RESPONSABILIDADE E A ENGENHARIA GENÉTICA

Marijane Lisboa

SOBRE A NECESSIDADE DE UMA NOVA FILOSOFIA DA NATUREZA: APROXIMAÇÕES ENTRE FRANCK TINLAND E HANS JONAS

Sarah Moura

A LIBERDADE À LUZ DO PRINCÍPIO VIDA DE HANS JONAS

Sylvia Valéria Pinheiro

O GNOSTICISMO ANTIGO E O EXISTENCIALISMO CONTEMPORÂNEO: DUAS VERSÕES DO NIILISMO SEGUNDO HANS JONAS

Thiago Vasconcelos

HANS JONAS - CLONAGEM REPRODUTIVA HUMANA E CUIDADO CRIATIVO

Wendell E. S. Lopes 


\section{EDITORIAL}

Alegria e satisfação são os sentimentos que acompanham a edição deste número especial dos Cadernos Cajuinas sobre Hans Jonas! Estão aqui reunidos textos de conferências e comunicações proferidas no II Seminário Hans Jonas da UFRJ, realizado há exatos dois meses, no período de 7 a 9 de dezembro de 2016.

Este encontro congregou renomados professores brasileiros e estrangeiros, e estudantes de pós-graduação e graduação de oito estados brasileiros - Rio de Janeiro, São Paulo, Minas Gerais, Paraná, Goiás, Mato Grosso, Sergipe e Piauí. A participação do Professor Eric Pommier - Doutor em Filosofia pela Sorbonne, Professor na PUC de Santiago do Chile - e do Professor Roberto Tibaldeo Franzini - Doutor pela Universidade de Turim (Itália), realizando pós-doutoramento na Universidade Católica de Louvain (Bélgica) deu o caráter internacional ao evento. Infelizmente, por questões de direitos autorais, não foi possível publicar aqui as suas conferências.

As pesquisas apresentadas e as discussões realizadas neste seminário abarcaram as temáticas da filosofia jonasiana da gnose à bioética, com reflexões sobre: a ontologia da vida; os fundamentos e a consistência lógica de sua ética; a necessidade de uma profunda análise crítica da utopia do progresso, exaltada desde o século XVII, e da dinâmica tecnocientífica e consumista que hoje rege; a necessidade de uma nova filosofia da natureza e a importância da imagem do ser humano a ela integrada.

Ainda foram abordadas aproximações, corroborações e críticas ao pensamento de Hans Jonas com idéias de filósofos consagrados, como Aristóteles, Spinoza, Hobbes e Kant, bem como de pensadores contemporâneos como Hannah Arendt, Paul Ricoeur, Franck Tinland, Alasdair MacIntyre e Serge Latouche.

Em relação às questões bioéticas, tão intrinsecamente ligadas à hegemonia da tecnociência e à cultura do consumo, foram debatidos temas da engenharia genética, com ênfase no problema dos alimentos transgênicos, e da morte.

Além de ter sido um enorme prazer, foi também uma grande honra ter participado da organização deste encontro tão profícuo e marcado por um clima fraterno, e que concretiza suas contribuições na publicação deste número especial.

É preciso registrar minha profunda gratidão aos colegas do Grupo de Trabalho Hans Jonas da ANPOF, ao Programa de Pós-Graduação em Filosofia da UFRJ, à comissão organizadora do seminário, e em especial a João Farias - editor-chefe dos Cadernos Cajuina - e ao Professor Olinto Pegoraro, do Programa de Pós-Graduação em Bioética, por suas inúmeras e preciosas contribuições para esta realização. 
Que as sementes aqui plantadas encontrem solo fértil para germinar e florescer em pensamentos que, como os de Hans Jonas, nos ajudem a enfrentar eticamente os graves desafios de nosso tempo.

\section{Sarah Moura}

Doutoranda e Mestra em Filosofia pela UFRJ

Graduada em Medicina e Filosofia pela UFRJ

\section{COMITÊ CIENTÍFICO}

Olinto Pegoraro - PPGBios/UERJ

Ricardo Jardim - Prof. Titular Fil. Cont./UFRJ

Fernando Fragoso - PPGF/UFRJ

Sarah Moura - Doutoranda PPGF/UFRJ

Michelle Bobsin - Doutoranda PUC-Rio 


\title{
HANS JONAS E A FRAGILIDADE DE DEUS: O ELEMENTO TEOLÓGICO DA RESPONSABILIDADE ÉTICA ANTROPOCÓSMICA
}

Hans Jonas and The Fragility of God: The Theological Element in The Anthropocosmic Ethical Responsibility

\author{
Alexandre Marques Cabral \\ Doutor em Filosofia pela UERJ e \\ em Teologia pela PUC-RJ \\ Professor Adjunto do Departamento de Filosofia da UERJ \\ e do Instituto Federal Colégio Pedro II
}

RESUMO: O presente trabalho tem como objetivo central caracterizar a ideia de responsabilidade ecoteológica como sentido ético da obra jonasiana. Para tanto, é preciso, antes de tudo, assinalar o horizonte hermenêutico da ética de Jonas. Tal horizonte, como entendemos, não é outro senão aquele que emerge da ruptura radical com os dualismos metafísicos da tradição filosófica. Como se pode perceber, Jonas rompe com os dualismos metafísicos por meio de uma crítica radical da cosmovisão gnóstica de mundo, cosmovisão essa que, segundo ele, se reatualiza no pensamento moderno, seja em Pascal ou mesmo em Heidegger e Sartre. Após sua crítica ao gnosticismo, entendido como um modo específico de compreensão de mundo, Jonas interessa-se por promover uma filosofia da biologia que permita a realização de uma virada ética de seu pensamento. Nesse sentido, por causa de sua relação com o pensamento biológico, a ética jonasiana repensa a ética de modo cosmocêntrico, ressignificando a responsabilidade humana para além das relações interpessoais e da promoção de deveres que não se interessam pelo futuro da natureza como um todo. Justamente esse caráter cosmocêntrico da responsabilidade humana descerra o horizonte de inteligibilidade da questão de Deus. Conivente com sua crítica ao gnosticismo, o pensamento teológico jonasiano inscreve Deus no destino do impulso evolutivo da natureza. Por esse motivo, Deus se faz finito em cada ser natural e, no homem, experimenta o caráter decisivo da liberdade humana, estando susceptível ao bem e ao mal morais. Ora, a imanentização de Deus no curso evolutivo do cosmos passa a responsabilizar a liberdade humana pelo destino de Deus, que se decide no interior do curso da natureza. Isso funda, consequentemente, uma responsabilidade ecoteológica, critério de avaliação da eticidade dos comportamentos humanos.

PALAVRAS-CHAVE: Responsabilidade; ecoteologia; gnosticismo Deus. 


\section{INTRODUÇÃO}

O pensamento jonasiano tem uma complexidade peculiar. Afeito ao diálogo com a biologia, não se furta a pensar a técnica, a ciência moderna e, sobretudo, a ética no mundo atual. Contudo, engana-se quem pensa que Jonas está tão-somente interessado em produzir uma releitura peculiar daquilo que muitos acreditam ser os "tratados" ou "disciplinas" tradicionais da filosofia, ainda que Jonas também percorra o caminho da metafísica e da ontologia. O interesse inicial da démarche jonasiana pelo gnosticismo e, sobretudo, pela leitura existencial desse pensamento mítico-religioso que ele mesmo considerou "nebuloso, mitológico e tosco - estranho até mesmo para o seu tempo, e nunca acolhido na respeitável sociedade filosófica" (JONAS, 2004, p. 233) não assinala simplesmente um gosto exótico ou o desejo de produzir uma antifilosofia, mas deixa transparecer algumas questões decisivas para a compreensão do desdobramento de sua obra. A primeira dessas questões refere-se ao lugar do mito na criação do pensamento filosófico. Jonas não deixará de valorizar o mito e, mais que isso, fará dele uma estratégia metodológica importante para desenvolver o que poder-se-ia considerar como sua teologia. Essa, contudo, além de operacionalizar uma sólida narrativa mitopoética, aparecerá como horizonte de significatividade de suas preocupações éticas. Apesar disso, engana-se quem pensa ser Jonas um neognóstico, adjetivo que poder-se-ia utilizar para caracterizar o "espírito" da modernidade e seu caráter essencialmente niilista, segundo sua análise (Cf. Ibidem, p. p. 235-252). Antes disso, o pensamento teológico de Jonas estrutura-se, como veremos, por meio da assunção da crise dos binarismos metafísicos e das metanarrativas que lhe serviram, por muito tempo, de suposto teórico. Se Nietzsche afirma que "Deus está morto! Deus continua morto! E nós o matamos!” (NIETZSCHE, 2002, \ 125, p. 148), inscrevendo o deicídio no curso do desdobramento da história moderna ocidental à qual todos pertencemos, isso quer dizer que os referentes metaempíricos que tradicionalmente sustentaram as múltiplas experiências ocidentais esvaíram-se (Cf. CABRAL, 2014, \1-5). Essa impossibilidade de submeter o temporal ao eterno (ou vice-versa), o imanente ao transcendente (ou vice-versa), o plural ao uno (ou vice-versa), a matéria ao espírito (ou vice-versa), dentre outras dicotomias e sistemas interpretativos binários, de algum modo acaba atravessando o pensamento jonasiano, que rejeita peremptoriamente os dualismos metafísicos em geral. Por isso, todo pensamento teológico de Jonas distingue-se radicalmente de qualquer narrativa gnóstica.

A segunda questão que se torna visível por meio do interesse jonasiano pela narrativa mitopoética e por meio da rejeição dos dualismos gnóstico-metafísicos é o caráter judaico de sua obra. Por judaísmo, a semelhança de Lévinas, não entendemos um tipo específico de cultura, 
estruturado por um conjunto de normas religiosas e morais, alicerçadas em uma compreensão teológica monoteísta. Antes disso, como assinalou muito bem Lévinas, o judaísmo caracteriza-se por nutrir-se de uma relação com a divindade que somente ganha significatividade por meio da experiência ética. Isso quer dizer que o sentido do termo "Deus" só aparece por meio da virada ética das relações humanas. Como diz Lévinas: "Que a relação com o divino atravesse [no judaísmo] a relação com os homens e coincida com a justiça social, eis é o que define todo espírito da Bíblia judaica. Moisés e os profetas não se preocupam com a imortalidade da alma, mas com o pobre, a viúva, o órfão e o estrangeiro” (LÉVINAS, 1963, p. 36). Daí a afirmação: “ $A$ relação ética aparecerá no judaísmo como uma relação excepcional: nela, o contato com um ser exterior, no lugar de comprometer a soberania humana, a institui e a investe” (Ibidem, p. 31). É na virada ética que o judaísmo conquista sua especificidade e a relação com Deus ganha sua significatividade. Se para Lévinas a ética diz respeito à absoluta responsabilidade humana por outrem, em Jonas, a alteridade em jogo na ética é mais extensa: comporta todo e qualquer ente. É possível, nesse sentido, afirmar que Jonas dilata o conceito de alteridade e o compreende em toda parte daquilo que a teologia judaico-cristã-muçulmana chama de criação. Justamente nessa responsabilidade omniabarcante Jonas encontra o índice de significatividade de seu pensamento teológico. Sua narrativa mitopoética depende justamente dessa virada ética do pensamento judaico.

O intuito principal do presente trabalho não é outro senão caracterizar a especificidade da divindade pensada por Jonas em seu pensamento mitopoético, além de mostrar como o modo de ser dessa divindade onera radicalmente a responsabilidade humana, dela exigindo, concomitantemente, respostas éticas à totalidade dos entes, ao futuro da totalidade e ao ser de Deus. Para darmos conta desses propósitos, iremos seguir o seguinte percurso: 1. Da crítica ao dualismo gnóstico à responsabilidade ética; 2. Remitologização teológica, vulnerabilidade de Deus e responsabilidade hiperbólica; e 3. Considerações finais.

\section{DA CRÍTICA AO DUALISMO GNÓSTICO À RESPONSABILIDADE ÉTICA}

A crítica jonasiana do dualismo gnóstico(em verdade, como veremos, são dualismos, no plural)não se desenvolve plenamente em sua famosa tese doutoral orientada pelo teólogo protestante Rudolf Bultmann e acompanhada diretamente por Heidegger, A gnose e o espírito da antiguidade tardia. Ela aparece mais claramente no conhecido texto "Gnose, existencialismo e niilismo", publicado posteriormente em O princípio vida. Dito sucintamente, o objetivo desse texto paradigmático é o de ensaiar uma abordagem interpretativa da modernidade e de seu caráter 
niilista como uma retomada do logos interno animador e estruturador do gnosticismo. Ora, o que ele chama no título do ensaio e em seu desenvolvimento de "existencialismo" acaba se identificando com a expressão filosófica contemporânea que torna perceptível o caráter neognóstico da modernidade. Jonas pretende, portanto, realizar uma "leitura 'gnóstica' do existencialismo" (JONAS, 2004, p. 234), invertendo o que fizera em sua tese doutoral, a saber, uma leitura existencialista do gnosticismo. Se o que ele entende por existencialismo - que chega a abarcar Heidegger e Sartre, mas cujo caráter niilista encontra-se anteriormente em Pascal e Nietzsche - serviu de princípio hermenêutico do gnosticismo, então, se for possível utilizar o gnosticismo como princípio interpretativo do pensamento existencialista, tal compatibilidade deixa ver certa identificação por essência. "Noutras palavras, as funções interpretativas se invertem e tornam-se recíprocas [na relação entre gnosticismo e existencialismo] - a fechadura se transforma em chave, e a chave em fechadura" (Idem). Interessa-nos, aqui, tão-somente o modo como Jonas entende o caráter essencial do gnosticismo e como dois dualismos acabam são essenciais a ele. Como, então Jonas caracteriza o gnosticismo? Uma passagem de "Gnose, existencialismo e niilismo" ajuda-nos a responder essa questão:

O traço comum que importa realçar é o clima radicalmente dualista em que se baseia a atitude gnóstica como um todo, e que perpassa unificadamente suas diferentes manifestações, mais ou menos sistemáticas. As doutrinas dualistas se articulam sobre esta base primordialmente humana, e apaixonadamente vivida, de uma experiência do eu e do mundo. Existe o dualismo entre ser humano e mundo, e paralelamente a este o dualismo entre mundo e Deus. Trata-se de um dualismo não de grandezas complementares, mas sim de grandezas contrárias. E é um só, pois o dualismo entre ser humano e mundo repete no plano da experiência o dualismo entre mundo e Deus, dele se derivando como seu fundamento teórico; isto para não dizermos, inversamente, que a doutrina transcendente do dualismo mundo-Deus procede da experiência imanente da divisão homem-mundo, como sua base de experiência. (...) Em seu aspecto teológico esta doutrina afirma que o divino é estranho ao mundo e não tem nenhuma parte no universo físico; que o verdadeiro Deus, absolutamente transmundano, não é nem revelado pelo mundo nem por ele apontado, sendo por isso o desconhecido, o totalmente outro, que não pode ser reconhecido por nenhuma analogia mundana. Correspondendo a isto, o aspecto cosmológico da doutrina diz que o mundo é alheio a Deus, o alheio por excelência; que ele não é criação da divindade mas sim de um princípio inferior, cuja lei realiza. (Ibidem, p. 239)

Como fica claro no texto acima, para Jonas, o que se entende por cosmovisão dualista gnóstica (Cf. CULDAUT, 1996), em verdade, deve ser pensado pluralmente. Há o dualismo entre o eu e o mundo e o dualismo entre Deus e mundo. Ambos se referem diretamente à experiência vivida do eu e do mundo. Contudo, o dualismo eu-mundo é compreendido como derivado do dualismo Deus-mundo. Tais dualismos não são complementares, pois mundo/Deus e eu/mundo são grandezas contrárias. A presença de um dos termos exclui a possibilidade de integração do outro. Ora, no que tange à relação Deus-mundo, se ambos os termos são grandezas contrárias, o mundo jamais pode ser entendido como partícipe de Deus. Isso impede que se pense em relações 
analógicas que permitam falar de Deus, a partir das perfeições ontológicas que estruturam o mundo. Daí a conclusão de que Deus é alheio, o totalmente outro, o que não toma parte no mundo. Por isso a afirmação de Jonas em A religião gnóstica: “o 'estranho', em termos absolutos, é a totalidade transcendente, o 'mais além' é um eminente atributo de Deus". (JONAS, 2000, p. 85). Deus é, portanto, Deus absconditus. A divindade que se relaciona com o mundo não pode ser o totalmente outro, mas um princípio divino mau, inferior ou cego, muitas vezes representado pela tradição gnóstica como um Deus menor ou então como o Deus judaico criador do mundo (Gn 1), ou seja, a divindade criadora não é a divindade suprema. Disso decorre o fato de o mundo estar sempre sob o "império do demiurgo" (BAZÁN, 1978, p. 45) e não de Deus mesmo, independentemente da imagem que se faça desse demiurgo. Daí ser possível concluir: o Deus criador não liberta, encarcera (Cf. CABRAL, 2015).

O Deus que se esconde do mundo só pode relacionar-se salvificamente com o ser humano, se algo no ser humano não se imiscuir com o mundo, uma vez que este é um obstáculo, como vimos, para a experiência do Deus supremo. A condição de possibilidade da relação entre ser humano e Deus está em uma antropologia peculiar, de estrutura triádica. Se o platonismo de modo geral compreende o ser humano como corpo e alma e entende, no mais das vezes, essa relação de modo contrastivo e conflitivo, nas tradições gnósticas, na maior parte das vezes, o ser humano é compreendido como dotado de corpo, alma e espírito, o que forma a tipologia existencial do homem somático, homem anímico e homem pneumático, homem espiritual ou homem interior. Corpo e alma não levam o ser humano para além do espaço e do tempo, não emancipam o ser humano da volatilidade do devir das coisas exteriores. Homens somáticos e anímicos são sempre escravos da exterioridade; são escravos da divindade demiúrgica. Eles necessitam de emancipação e essa libertação, que se identifica coma experiência da gnose, só pode ser alcançada pela interioridade, que nada mais é que a vida do homem pneumático, ou seja, a vida segundo o espírito (Cf. Ibidem, p. 52-55; JONAS, 2004, p. 238-242). A lei emancipadora não pode vir do mundo, nem do corpo que com ele se relaciona, tampouco da alma, cuja atividade está ainda submetida ao horizonte mundano. A libertação vem de fora e atua naquilo que está escondido no ser humano, a interioridade humana. Deus absconditus e bomo absconditus se pertencem. Seu casamento depende de um afastamento do corpo, da alma e do mundo.

Se os pares eu-mundo e Deus-mundo são considerados dualismos de grandez̧as contrárias, as relações corpo-alma-mundo e Deus-espírito podem ser consideradas dualismos de grandezas complementares ou de correlação. Levando em conta que o conceito gnóstico de espírito assinala a ipseidade mais própria do ser humano, então deve-se dizer que somente fora do mundo, o ser humano vem a ser plenamente quem ele é. O tornar-se si mesmo pressupõe necessariamente um 
evidente acosmismo, ou seja, ser salvo é ser liberto do mundo. Justamente essa relação entre conquista de si e afastamento do mundo, que caracteriza essencialmente o gnosticismo, retorna sob novas roupagens na modernidade. Em verdade, a modernidade é caracterizada por aquilo que Jonas chamou de "niilismo cósmico" (Cf. JONAS, 2004, p. 238). Trata-se do esvaziamento do mundo como habitat essencial da ipseidade humana, índice sem o qual o ser humano não poderia vir a ser efetivamente quem ele é. Se o logos cósmico fora entre os estoicos, por exemplo, signo de harmonia, a modernidade o transformou em "destino cósmico escravizador" (Ibidem, p. 240). Os exemplos de Jonas não são aleatórios. Uma primeira caracterização do acosmismo moderno e de seu caráter niilista foi realizada por meio da referência aos pensamentos de Pascal e Nietzsche. Retomando em síntese os argumentos que expusemos alhures (Cf. CABRAL, 2015), Pascal afirma ser o coração o "lugar" em que o ser humano, por meio da fé, relacionar-se-ia com a transcendência absoluta de Deus, divindade essa que, ainda que pensada sob os moldes da ortodoxia católica, não toma parte com o mundo, uma vez ser este, enquanto coisa extensa (res extensa), somente fonte de medo, já que no mundo experimentamos a indiferença do universo e nossa total vulnerabilidade diante dele. Dito de outro modo: "A extrema contingência de nossa existência no todo priva do sentido do ser humano este todo como possível sistema de referência para a compreensão de nós mesmos" (JONAS, 2004, p. 236). Por outro lado, o famoso fragmento póstumo de Nietzsche que diz "O niilismo está à porta: de onde nos vem esse mais sinistro de todos os hóspedes?” (NF/FP 2 [127]) assinala que o niilismo, por ter entrado em nossa "casa", já retirou de nós a antiga familiaridade com o mundo, transformando-nos em estrangeiro na própria pátria. $\mathrm{O}$ acosmismo acaba, portanto, se identificando com a experiência de niilismo: nada no mundo é dotado de plena significatividade, o que nos impele a ir para além do mundo na esperança de sermos nós mesmos. Sem entrar em seus pormenores, deve-se observar que essa "lógica" niilista do acosmismo moderno, segundo Jonas, encontra nos "existencialismos" uma voz privilegiada.

Para se compreender a crítica de Jonas ao dualismo gnóstico e a todo niilismo que lhe é inerente, uma excelente porta de entrada é a constatação jonasiana de que a tradição ocidental construiu-se sobre um esquecimento peculiar: o esquecimento da vida em sua unidade e multiformidade constitutivas. No lugar do esquecimento do ser heideggeriano (Cf. HEIDEGGER, 2006, \1), Jonas interessa-se pelo esquecimento da vida. Como Jonas mostra em O princípio vida, as culturas antigas são pan-vitalistas. Isso aparece tanto no animismo, quanto no hilozoísmo. "A 'alma' ocupava o todo da realidade, e ela se encontrava a si própria em toda parte. A matéria 'pura', isto é, matéria 'morta', não fora ainda descoberta - já que esta suposição, hoje tão familiar a todos, nada possui de evidente" (JONAS, 2004, p. 17). Somente séculos depois, já 
em meio à civilização ocidental, a humanidade inverteu o pan-vitalismo transformando-o em pantanatologismo. Esse se caracteriza por compreender a morte como elemento comum e essencial ao ser. A matéria passa a ser vista sobretudo como matéria morta e a vida torna-se, em verdade, uma exceção e não mais a regra. Somente esta pré-compreensão ontológica permitiu supor que a matéria é regulada por um conjunto de forças cegas, sem destino, reguladas pelas leis de conservação. Ao rechaçar essa construção teórica (com fortes implicações ético-políticas), Jonas entende ser necessário ater-se à recuperação de certa compreensão ontológica pan-vitalista. Daí a tarefa de pensar a "vida material, portanto [o] corpo vivo, em suma, [o] ser orgânico" (Ibidem, p. 34). A discussão com a biologia é, portanto, inevitável, ainda que Jonas não pretenda reduzir a filosofia a um simples arremedo biologicista. Consequentemente, é no conceito filosófico de vida que Jonas pretende superar os binarismos da tradição e abandonar de vez o neognosticismo niilista que ainda ronda nossa cultura. O que então Jonas entende por vida? Qual sua importância para sua filosofia? Como esse conceito possibilita fundamentar a responsabilidade ética?

O conceito jonasiano de vida é claramente analógico e orientado por certa compreensão evolucionista. O que interessa a Jonas é, basicamente, entender como a matéria, que a modernidade entendeu como morta, é capaz de vida e como essa manifesta-se pluralmente, dando margem sobretudo à vida humana. Evolutivamente, a vida se manifesta em um sentido ascendente, onde as formas primitivas abrem espaço para formas mais complexas, em que aparecem as sensações, a imaginação, a vontade, a memória, o pensamento etc. Ora, isso não significa que os seres vivos primitivos sejam vistos meramente como incapazes de ter perfeições mais complexas como as que se manifestam nos demais seres vivos. Antes, Jonas entende a vida primitiva como já dotada de uma série de aspectos que se tornam mais evidentes nas vidas mais evoluídas. Ele destaca a liberdade como característica desde sempre presente na vida orgânica. Ela aparece nos seres vivos primitivos por meio do metabolismo. "Trata-se de um conceito ontológico descritivo que num primeiro momento pode referir-se a meros fatos corpóreos" (JONAS, 1998, p. 17). Com a liberdade inscrita na vida, acontece a "irrupção do ser no espaço ilimitado das possibilidades" (Idem). Vida e possibilidade criativa (inventividade da própria vida) se conjugam e se determinam mutuamente. Daí a estratégia de Jonas de pensar a liberdade como fio condutor para se compreender a polimorfia da vida. Essa relação entre liberdade e possibilidades vitais assinala o caráter de risco presente em todo vivente. Não é necessário que toda iniciativa da vida obtenha êxito, pois é sempre possível a falência de seus projetos e empreendimentos. Por isso, toda vida orgânica experimenta de modos distintos a tensão entre ser e não-ser, tensão essa ausente dos seres inorgânicos. Nesse caso, todo ser orgânico existe em relação aos seres inorgânicos, porém sem se identificar com eles - "a substância vivente se 
separou da integração geral das coisas na totalidade da natureza, de modo que ficou diante do mundo introduzindo, assim, a tensão entre 'ser e não ser' na segurança anterior indiferente da posse da existência" (Ibidem, p. 18). Isso equivale a dizer que a irrupção da vida é concomitante à introdução do fenômeno da finitude, ou seja, da morte. Daí a equação: ser vivo $=$ ser mortal. Desse modo, a vida é marcada radicalmente por vulnerabilidade.

Se Jonas considera a liberdade "um conceito-guia capaz de orientar-nos na tarefa de interpretar a vida" (Ibidem, p. 106), então é ela que concentra em si os caracteres ontológicos essenciais na constituição dos seres vivos. Nesse caso, liberdade, como elemento ontológico essencial, não se identifica com livre-arbítrio ou mesmo com a autoafirmação da vontade de um ser racional. Antes disso, a liberdade assinala a relação dialética de todo ser vivo com o meio em que vive. Por um lado, o ser vivo metabolicamente modifica o meio; por outro, tal tarefa criativa aparece como uma necessidade, pois sem ela a vida não acontece. Daí a relação dialética entre liberdade e necessidade (Ibidem, p. 107), sem a qual nenhum ser orgânico desdobra seu ser. Concomitantemente, a vida só é possível se estiver aberta ao meio ambiente. Ser-no-mundo é o caráter de todo vivente e não somente da condição existencial do ser humano (Cf. HEIDEGGER, 2006, \ 15-18), o que abre o campo para sua vulnerabilidade, ao mesmo tempo que o obriga a transformar criativamente o meio em que vive. Ora, tal vulnerabilidade, que se dá na relação umbilical com o mundo, não é abstrata, mas individualizada. Isso porque só existe vida na individualidade de cada vivente. Dessa forma, a relação do vivente com o mundo não pode ser de subsunção, seja de si, seja do mundo. Antes, o vivente, por ser "individualidade autocentrada, existindo para si e em oposição a todo resto do mundo, com um limite essencial entre o dentro e o fora" (JONAS, 2004, p. 101), relaciona-se com o mundo agonisticamente, por meio de uma multiplicidade de trocas. Disso surge a característica de todo vivente: ser autoafirmador. Ele afirma a si mesmo por meio de uma relação de apropriação seletiva dos diversos elementos do mundo. Somente assim a ipseidade (mesmidade) do vivente se forma. Não se trata, é claro, de uma identidade substancialmente fundada, mas de uma identidade "que se faz de momento a momento, que sempre de novo se afirma forçando as forças igualizadoras da mesmidade física, encontra[r]-se em uma tensão essencial com o todo das coisas" (Ibidem, p. 106). Daí a temporalidade insuprimível da vida. Ora, disso é possível se destacar o fato de o vivente necessitar sempre do meio, para afirmar a cada vez a si mesmo; contudo, essa afirmação se estrutura por meio de uma relação agonística de apropriação e seletividade com o meio. Somente nessa relação de tensão dialética se explica como a vida desdobra-se entre o ser e o não-ser e necessita transcender os múltiplos elementos do mundo e as formas de si já configuradas, para a 
cada vez (re) criar a sua ipseidade. Vida, transcendência, agonística, temporalidade, finitude e mundo se interpenetram essencialmente.

Com o aparecimento do espírito (humano) no seio da vida, a liberdade assume novos contornos. O ser humano produz um sistema teleológico para organizar, legitimar suas ações e consumar sua vontade. Não somente isso. O ser humano consegue agir em consonância com certo conhecimento dos efeitos de suas ações. Isso porque a liberdade humana ou a liberdade "transanimal” (JONAS, 2010, p. 30) permite-o transcender a situação e "estabelecer metas transcendentes" (Idem). Na liberdade humana, há também a possibilidade de o eu fazer de si seu próprio tema. Justamente esse movimento reflexivo transforma a subjetividade do eu em objeto de avaliação axiológica: o eu "torna-se sujeito ao julgamento da consciência moral" (Ibidem, p.32). Por meio dessa relação reflexiva de cunho ético, o eu cuida de realizar, nas múltiplas relações com os seres mundanos, os valores que determinam sua interioridade. Ora, como o espírito humano é irredutível às situações em que ele se determina, os valores éticos podem assumir caráter infinito ou absoluto, fundando a insuprimível diferenciação entre bem e mal. É claro que muitas vezes o mal disfarça-se de bem e as boas ações transformam-se em máscaras para atualização de força destruidora do mal. Isso, contudo, não retira do ser humano a responsabilidade pelos efeitos de sua ação e pelos seres que compõem o meio onde ele mesmo vive e sem os quais ele não pode afirmar seu ser. Eis, portanto, a copertinência de ontologia da vida e responsabilidade ética. Ora, à luz do que fora dito, deve-se dizer: se a responsabilidade ética está fundada na estrutura ontológica da vida; se a vida humana depende de sua relação com o mundo; se uma das condições da vida é a temporalidade, então, não é possível pensar a responsabilidade ética à luz de valores trans-históricos de caráter metafísico. Isso porque, como disse Ricoeur, “o objeto ou, melhor dizendo, o correspondente da responsabilidade é o perecível enquanto tal" (RICOEUR, 1996, p. 230). Por isso, a responsabilidade ética deve se fundar na universalidade da vulnerabilidade dos seres e na necessidade de afirmar a perpetuação da multiplicidade de modos de a vida se manifestar, para que as condições propicias para a vida tenham futuro e a vida como tal siga adiante. Disso decorre as três formulações do imperativo ético jonasiano, em O princípio responsabilidade, que tornam visível a responsabilidade humana pela vulnerabilidade dos seres e pelo futuro da vida:

\footnotetext{
"Age de modo a que os efeitos da tua ação sejam compatíveis com a permanência de uma autêntica vida humana sobre a Terra'; ou, expresso negativamente: 'Age de modo a que os efeitos da tua ação não sejam destrutivos para a possibilidade de uma tal vida' (...) 'Não ponhas em perigo as condições necessárias para a conservação indefinida da humanidade sobre a Terra' (...) 'Inclui na tua escolha presente a futura integridade do homem como um dos objetos do teu querer"' (JONAS, 2006, p. 47-48).
} 


\section{REMITOLOGIZAÇÃO TEOLÓGICA, VULNERABILIDADE DE DEUS E RESPONSABILIDADE HIPERBÓLICA}

A ressignificação do conceito de vida e a transformação deste em mobilizador do pensamento ético permitiu a Jonas desconstruir a força normativa dos dualismos gnósticos e, com esses, também os dualismos metafísicos em geral. Isso lhe permitiu encerrar na ética o sentido último da filosofia. Contudo, sua ética não se reduz ao âmbito intersubjetivo, mas antropocósmico. Ela não está baseada na reciprocidade dos comportamentos éticos. Antes, levando em conta uma terminologia pertencente ao léxico filosófico de Lévinas, a ética jonasiana está preocupada com a relação assimétrica com as alteridades humanas e não humanas. Deve-se responder pelo futuro de todos os viventes, ainda que esses não respondam pelo meu futuro. Como poderia esperar que uma barata responda por mim do mesmo modo como eu devo responder pelo seu futuro? Isso permite-nos falar em assimetria ética no interior da responsabilidade humana. Ora, se a significatividade última do pensamento jonasiano está na ética; se os imperativos éticos jonasianos só podem ser realizados por meio de um diálogo criativo com as situações dos viventes em geral e com todos os demais seres que garantem a perpetuação da vida na Terra, então a racionalidade ética pensada por Jonas é também marcadamente criativa. Mais ainda. Se Jonas não se orienta por instâncias ontológicas metaempíricas para fundamentar seu pensamento, então é possível dizer que sua ética se perfaz por meio da assunção da crise dos binarismos metafísicos da tradição. Justamente isso permite superar a clássica dicotomia entre mito e lógos, sempre repressora do logos apofântico, objetivante ou demonstrativo em detrimento do mito, esse pseudossaber inerente a seres humanos racionalmente involuídos. Ao contrário de seu mestre Rudolf Bultmann, que operacionalizou o procedimento desmitologizador como meio para descrição das modulações existenciais subjacentes às narrativas bíblicas (Cf. BULTMANN, 1999, p. 95), Jonas utiliza narrativas mitopoéticas para dar conta de novas possibilidades positivas ou afirmativas de significação de seu projeto ético. Melhor dizendo: as narrativas mitopoéticas permitem a Jonas, semelhantemente a Platão, admitir e pensar a partir da "esfera mais além do cognoscível" (JONAS, 1998, p. 198). O poder especulativo dessa instância transracionaldilata o sentido ético do pensamento judaico. Nesse tipo de narrativa inscreve-se a questão de Deus. Como, então Jonas compreende o conceito de Deus? Como a remitologização do pensamento filosófico pode favorecer a ética jonasiana? Qual a relação entre Deus e ética?

Jonas compreende o problema de Deus a partir do terror da Shoá. Por conseguinte, Deus e o genocídio promovido pelos holocaustos da Segunda Guerra Mundial formam uma relação 
que não somente permite ressignificar o problema do mal, como sobretudo confrontar as teodiceias da tradição judaico-cristã, exigindo delas uma profunda transformação discursiva. Isso aparece paradigmaticamente no texto $O$ conceito de Deus após Auschwitr. Esse texto, além de reposicionar a questão da divindade a partir dos terrores dos campos de concentração, permitenos compreender por que razão a questão da divindade leva Jonas afirmar eticamente a necessidade de respondermos pela multiplicidade de alteridades que compõem o tecido da vida na Terra. Como, então a divindade é pensada por Jonas à luz de Auschwitz? Como já deve ter ficado claro, não se trata de mais uma narrativa teológica fundamentada metafisicamente, com a pretensão de dizer o que é Deus nele mesmo. Lembrando o que fora dito, trata-se de uma narrativa mítica com o propósito de elevar o pensamento a um âmbito de inteligibilidade mais originário que aquele das simples explicações lógico-analíticas. Para entendermos a compreensão jonasiana de Deus, vejamos sucintamente os contornos mais significativos desse conceito, à luz do ensaio O conceito de Deus após Auschwitz:

Segundo o mito criado por Jonas, Deus criou o mundo e inseriu-se totalmente na criação, passando a viver segundo suas [da criação] possibilidades e limites. Nos seres inorgânicos, Deus encontrou certas possibilidades de afirmação de si que não encontrou nos vegetais. $\mathrm{O}$ mesmo aconteceu nos animais e, por fim, na condição humana. Deus se fez sujeito ao devir criatural, ou seja, Deus tornou-se vulnerável ao devir. Como Jonas mesmo afirma: "para que possa existir o mundo, Deus renuncia a seu próprio ser; despoja-se de sua divindade para tornar a recebê-la da odisseia do tempo, carregada com a colheita ocasional de experiências temporais imprevisíveis, sublimada ou talvez também desfigurada por elas." Não só isso. "Nesse abandono de si mesmo da integridade divina a favor do devir incondicional não se pode supor nenhum outro saber prévio salvo o que se refere às possibilidades que o ser cósmico oferece devido às suas próprias condições: precisamente a estas condições entregou Deus sua causa quando se alienou a favor do mundo" (JONAS, 1998, p. 199). Em meio ao devir do espírito humano, Deus encontrou-se à mercê das vicissitudes de sua liberdade e, por isso, suas transformações passaram a relacionar-se com os efeitos dos atos humanos. Por isso, a afirmação de Jonas afirma em "Imortalidade e existência atual", texto presente em O princípio vida: "O surgimento do ser humano significa o surgir de conhecimento e de liberdade, e com esse duplo fio extremamente cortante a inocência do mero sujeito de uma vida que se autoplenifica cede lugar à tarefa da responsabilidade situada sob a disjunção do bem e do mal." Daí a conclusão: "Pela primeira vez a realização da causa divina está, de agora em diante, confiada à chance e ao risco dessa dimensão, sem êxito oscilando na balança" (JONAS, 2010, p. 266-267). Se o ser humano decide moralmente seu destino, então, na realidade humana, o ser de Deus é decidido moralmente, o que equivale a dizer que Deus 
assume o risco dos efeitos dos comportamentos éticos dos seres humanos. Ele sofre o bem e mal na "pele". Ora, os atos humanos incidem em Deus não pelo que o ser humano realiza com a transcendência divina, mas por meio do modo como moralmente o ser humano responde pelos viventes. Isso possibilita-nos dizer que o ser de Deus é essencialmente atingido pelos atos morais do ser humano. Vejamos a passagem completa em que Jonas descreve o seu mito da criação, segundo aparece em $O$ conceito de Deus após Auschwitz:

No princípio, por uma escolha desconhecida, o fundo divino do ser decidiu entregar-se à aventura e à infinita diversidade do devir. E o fez totalmente. Ao integrar-se na aventura do espaço e do tempo, a divindade não reteve nada dela mesma; não permaneceu nenhuma parte inacessível e imune dela para dirigir, corrigir e finalmente garantir a partir de fora a sinuosa formação de seu destino no mundo do criado. O espírito defende esta imanência incondicional. Seu valor ou seu desespero, e em todo caso sua radical sinceridade, o obrigam a levar a sério nosso ser-no-mundo, quer dizer, a entender o mundo como abandonado a si mesmo, suas leis como fechadas a qualquer intromissão e o rigor de nossa pertença a ele como não atenuado por uma providência extramundana. Isto mesmo afirma nosso mito do ser-no-mundo de Deus. Mas, não no sentido de uma imanência panteísta, porque se Deus e o mundo são simplesmente idênticos, o mundo representa em todo momento e em qualquer estado sua plenitude, e Deus não pode nem deve ganhar. Melhor, para que possa existir o mundo, Deus renuncia a seu próprio ser; despoja-se de sua divindade para tornar a recebê-la da odisséia do tempo, carregada com a colheita ocasional de experiências temporais imprevisíveis, sublimada ou talvez também desfigurada por elas. Neste abandono de si mesmo da integridade divina a favor do devir incondicional não se pode supor nenhum outro saber prévio salvo o que se refere às possibilidades que o ser cósmico oferece devido a suas próprias condições: precisamente a estas condições entregou Deus sua causa quando se alienou a favor do mundo." (JONAS, 1998, p. 199)

Desse mito da criação segundo o qual Deus se inscreve totalmente (sem sobras) na criação (Deus é ser-no-mundo, e não somente o ser-aíheideggeriano) e assume as possibilidades fornecidas pela finitude de cada ser criado, surgem novos e importantes atributos divinos, que Jonas resume em três, a saber: a) a passibilidade divina - Deus é sofredor -; b) mutabilidade divinaDeus está em devir -; e c) não indiferença divina - Deus preocupa-se consigo e com a criação. Deus é sofredor, em um duplo sentido. Primeiramente, ele sofre as transformações do curso da criação. Aqui, mais que em qualquer outro lugar, Jonas está levando adiante uma forte tendência do pensamento judaico contemporâneo em desconstruir a apatia divina, tal como as narrativas metafísicas quase sempre entenderam. Que bastem aqui dois exemplos. O primeiro se refere ao já clássico Abraham Heschel.Em sua obra Os profetas, Heschel assinalou a não indiferença do Deus de Israel, ou seja, afirmou o caráter teopática da experiência judaica de Deus. Trata-se do pathos divino, que segundo sua análise do profeta Isaías, nada tem a ver com um "páthos como emoção", mas refere-se "a um páthos em ação" (HESHEL, s/d, p 164). Justamente esse páthos em ação se 
traduz em aflição e intervenção divinas. Como afirmou o teólogo protestante Jürgen Moltmann, ao interpretar o pensamento de Heschel: "[O páthos de Deus] Não tem nada que ver com emoções humanas irracionais, como o desejo, a raiva, a ansiedade, a inveja, ou a simpatia, mas descreve a maneira com a qual Deus é afetado pelos eventos, ações humanas e sofrimento na história" (MOLTMANN, 2014, p. 344). Em segundo lugar, Deus sofre as consequências dos atos morais humanos, inclusivo os maus atos, que produzem dor. "Se o que disse tem sentido, este sentido é que a relação de Deus com o mundo inclui um sofrimento desde o momento da criação" (JONAS, 1998, p. 203). Trata-se da teopatia: o ser de Deus é afetado radicalmente pela criação. Isso só se explica porque Deus é suscetível ao devir da criação. Em outros termos: Jonas retira de Deus a imutabilidade que a metafísica tradicional concebera como um de seus principais atributos. Por isso, ele não somente sofre o devir das criaturas, como também está em devir Deus vem a ser quem ele é por meio do devir criatural. Nas suas palavras: "[Deus é] afetado pelo que acontece no mundo, e 'afetado' significa 'alterado', transformado em seu estado” (Ibidem, p. 204). Essa teopatia, essa afecção divina, que transforma Deus em um ente em devir, traz à baila o cuidado divino pela criação, não no sentido de que Deus intervém na criação, mas no sentido de que ele preocupa-se com ela e consigo, pois depende do curso da criação para dela receber as possibilidades de apropriar-se de si mesmo. Jonas chega a dizer: "também [ele] é um Deus ameaçado, um Deus com um risco próprio" (Ibidem, p. 205). É o risco que faz de Deus um ente preocupado - seja consigo, seja com a criação. Ora, se o grande risco divino está na moralidade humana, então, por causa da liberdade do espírito, Deus depende do ser humano. Essa razão por que Jonas, em Matéria, espírito e criação, cita um belíssimo texto/oração da judia Etty Hillesum, morta em Auschwitz, em 1943.

Irei a qualquer canto desta terra, aonde Deus me enviar, e estou disposta a testemunhar em qualquer situação e até a morte, [...] que não é de Deus a culpa por tudo ter sobrevindo assim, mas nossa.

[...] E se Deus não mais me ajudar, então devo ajudar a Deus [...] esforçar-me-ei sempre em ajudar a Deus o quanto me for possível [...]

Eu quero ajudá-lo, Deus, a não me abandonar, embora não possa garantir mais nada daqui para frente. Apenas uma coisa está se tornando cada vez mais clara para mim: que o Senhor não pode nos ajudar, mas nós é que devemos ajudar o Senhor a nos ajudar e, desta forma nos ajudamos, por fim, a nós mesmos.

Eis a única coisa que importa: salvar em nós próprios algo de ti, Deus [...] Sim, meu Deus! Não há mesmo o que quer que seja que o Senhor possa fazer a respeito de nossa situação [...] Não peço justificação alguma de ti; será o Senhor que mais tarde nos exigirá justificações. E a cada batida de meu coração tornase mais claro que o Senhor não nos pode ajudar, mas nós é que temos que ajudar o Senhor, e assim defender sua morada em nós até o fim. (JONAS, 2010 b, p. 67-68) 
Se respondemos pelo ser divino em cada comportamento ético, então nossa responsabilidade é absoluta exatamente pelo fato de que respondemos pelo eterno em cada ato temporal. Mais que isso. Respondemos pelo futuro de Deus, ao respondermos pelo futuro da criação. Fica claro então o caráter escatológico da ética jonasiana. O ser humano é responsável, simultaneamente, pelo futuro do criador e da criatura, onde ele mesmo se inclui. Dito de modo mais claro ainda: agir moralmente é ser responsável pelo futuro dos vivente e pelo futuro de Deus. Isso desconstrói a velha teodiceia segundo a qual Deus não criou o mal, mas esse nasceu do mau uso do livre arbítrio, possibilitado pela condição ontológica da finitude humana. Agora, o problema do mal encontra outro destino: Deus não é princípio explicativo do mal. Ele é sofredor dos males. Seu sofrimento interpela-nos. Suas dores exigem de nós novas respostas. Responder pelo futuro da criação é responder pela libertação ou opressão do destino de Deus. Por isso, somente esse Deus absolutamente vulnerável e frágil transforma a teologia em responsabilidade ética com a totalidade da criação. Em outros termos: se outrora lançávamos mão da onipotência divina para lidarmos com os impasses da criação, agora, devemos responder pela fragilidade divina, mediante plena responsabilidade pelo curso da criação. O problema da alteridade (de Deus e das demais criaturas) tem agora caráter ecoteológico. Talvez, somente uma ética ecoteológica que afirme a fragilidade de Deus permita resistir à violência sistematizada aos sistemas de vida da Terra.

\section{CONSIDERAÇÕES FINAIS}

A estratégia jonasiana de construção de uma sólida narrativa mitopoética acerca da absoluta fragilidade de Deus não serviu para legitimar qualquer tipo de irracionalismo, mas tãosomente para produzir a máxima potencialização da responsabilidade ética com a totalidade da vida. Trata-se de um elemento teológico importante para o fortalecimento da racionalidade ética. O mito, portanto, não é, nesse caso, signo de insuficiência de racionalidade. Antes, o mito jonasiano possibilita, a um só tempo, ressignificar a discursividade religiosa no tempo da crise das metanarrativas metafísicas, inserir Deus no âmbito do destino do mundo e afirmar o sentido ético do pensamento filosófico como tal. Talvez seja possível ver aí a intercessão da racionalidade judaica na filosofia e a possibilidade de interpenetração de dois regimes discursivos, que não necessariamente se excluem. Exatamente isso livro Jonas do caráter antropocêntrico da ética moderna e o libertou dos dualismos de caráter gnóstico, que em verdade desvinculam radicalmente o ser humano da totalidade mundana. Ainda que a teologia jonasiana seja a teologia da imanentização radical de Deus, é na responsabilidade ética que a transcendência divina aflora e Deus apropria-se cada vez mais de si mesmo em seu destino antropocósmico. Por isso, um Deus 
que se inscreve na natureza, sem ter ele mesmo a mesma dignidade ontológica da natureza, produz um reencantamento do horizonte ético e transforma o ser humano em ser essencialmente messiânico. Somente a fragilidade de Deus faz traz ao ser humano a sua vocação messiânica. 


\section{REFERÊNCIAS}

BAZÁN, Francisco García. Aspectos incomuns do sagrado. São Paulo: Paulus, 2005.

Gnosis: laesenciadel dualismo gnostico. Buenos Aires: Castañeda, 1978.

BIBLIA DE JERUSALEM. São Paulo: Paulus, 2002.

BRILL, E.J. (Org.) The NagHammadi Library in English. Leiden: The Netherlands, 1996.

BULTMANN, Rudolf. Teologia do Novo Testamento. Santo André: Academia Cristã, 2008.

Le christianisme primitif dans le cadre des religions antiques. Paris: Petite

Bibliotèque Payot, 1969.

Demitologização: Coletânea de ensaios. São Leopoldo: Sinodal, 1999.

CABRAL, Alexandre Marques. Niilismo e hierofania: uma abordagem a partir do confornto entre Nietzsche, Heidegger e a tradição cristã. Vol. 1. Nietzsche, cristianismo e o Deus não-cristão. Rio de Janeiro: Mauad X/Faperj, 2014.

.Hans Jonas, gnosticismo e a questão de Deus: entre redenção da natureza e compromisso ético”. Revista Numen. v 18, n 1, (2015)

CHURTON, Tobias. Los gnósticos: latradición oculta. Madrid: Edaf, 1988.

CULDAUT, Francine. El nascimientodel Cristianismo y el gnosticismo: propuestas. Madrid: Akal, 1996.

FIORILlO, Marília. O Deus exilado: uma breve história de uma heresia. Rio de Janeiro: Civilização Brasileira, 2008.

HEIDEGGER, Martin. Marcas do caminho. Petrópolis: Vozes, 2008. . SeinundZeit. Tübingen: Max Niemeyer, 2006.

HESCHEL, Abraham. Los profetas: elhombre y suvocación. Buenus Aires: Paidos, s/d.

JONAS, Hans. O princípio vida. Petrópolis: Vozes, 2004.

. Matéria, espírito e criação. Petrópolis: Vozes, 2010.

Pensar sobre Dios y otrosensayos. Barcelona: Herder, 1998. 
La religión gnóstica: El mensajedelDiosExtraño y loscomienzosdel cristianismo. Madrid: Siruela, 2000.

. O princípio responsabilidade. Rio de Janeiro: Contraponto, 2006.

$\begin{array}{lllcr}\text { GnosisundspätantikerGeist. } & \text { I: } & \text { Die } & \text { mythologischeGnosis } & \text { MIT } \\ \text { einerEinleitungzurGeschichteundMithologie } & \text { der } & \text { Forschung. } & \text { Göttingen }\end{array}$ :Vandenhoeck\&Ruprecht, 1964.

LÉVINAS, Emmanuel. DifficileLiberté: EssaissurleJudaisme. Paris: Albin Michel, 1963.

MOLTMANN, Jürgen. O Deus crucificado. Santo André: Academia Cristã, 2014.

NIETZSCHE, Friedrich. SämtlicheWerke. KritischeStudienausgabe. Edição organizada por Giorgio Colli e MazzinoMontinari. 15 Vols. Berlim: Walter de Gruyter, 1967-1978. A gaia ciência. Trad. de Paulo César de Souza. São Paulo: Companhia das Letras, 2002.

PASCAL, Blaise. Pensamentos. São Paulo: Martins Fontes, 2005.

PUECH, Henri Charles. Enquête de la Gnose. Paris: Gallimard, 1978. Vol. I: La Gnose et letemps.

RICOEUR, Paul. A região dos filósofos. São Paulo: Loyola, 1996.

SCHOLEM, Gershon. Conceptos básicos del judaísmo: Dios, Creación, Revelación, Tradición, Salvación. Madrid: Trotta, 2008.

A mística judaica. São Paulo: Perspectiva, 1972. 


\section{LIBERDADE NOS NÍVEIS PRIMITIVOS DA VIDA NA FILOSOFIA DE HANS JONAS}

Liberty in the primitive levels of life in the philosophy of Hans Jonas

Bruno Henrique do Rosario Xavier.

Graduando em Filosofia - PUC Paraná.

Orientador: Dr. Anor Sganzerla - PUC Paraná

RESUMO: O tema central desse trabalho é a filosofia do organismo de Hans Jonas. Desse modo, o objetivo da presente pesquisa consiste em analisar a liberdade dialética nos organismos que sobrevivem graças à capacidade metabólica, segundo o sistema filosófico jonasiano. A metodologia utilizada foi a analítica sintética em que se percorreu as principais obras de Jonas sobre o tema, sobretudo, sua obra O princípio vida e de comentadores que auxiliaram no desenvolvimento do trabalho. Com o resultado da pesquisa constatamos que a liberdade já pode ser encontrada nos primeiros estágios de vida, mas de modo diferente daquele que se expressa nos seres humanos. Partindo do darwinismo, Jonas compreende que os estágios de liberdade vão se construindo de liberdade inferior à liberdade superior, camada sobre camada, em um sentido de evolução. É nesse sentido que Jonas afirma que o metabolismo é o elemento pelo qual o ser se distingue da mera materialidade sem objetivo, ao mesmo tempo que abre a possibilidade para a existência da subjetividade na matéria, colocando o ser orgânico na polarização entre o si mesmo e o mundo. Para manter seu ser, a vida precisa realizar seu fazer. Aqui é exposto o caráter precário da liberdade, pois na medida em que o orgânico escolhe a vida, ele precisa, necessariamente, o fazer, pois deixar de fazer significa morrer. É pela transcendência, pelo ter o mundo, que a vida orgânica afirma sua liberdade, que nesse contexto, tem predominância sobre a necessidade.

PALAVRAS-CHAVE: Liberdade dialética; Vida; Ontologia. 


\section{INTRODUÇÃO}

Esta pesquisa objetiva analisar os aspectos subjetivos do ser orgânico oriundos de sua soberana primazia no reino da matéria, a saber, do metabolismo. Sendo assim, o trabalho analisa o entendimento jonasiano da atividade metabolizante e quais os caracteres interiores que ela traz em si para a vida orgânica. Para tal fim utilizamos a leitura de textos filosóficos, em que percorremos as obras dos autores, com ênfase em O princípio vida, e em diversas obras de comentadores da área.

Para que a compreensão do tema ocorra de forma mais satisfatória possível, dividimos o presente trabalho em três seções principais: identidade e liberdade: uma análise do que aparece objetivamente do ser vivo a partir da leitura filosófica de Jonas do sistema metabólico, no qual analisaremos o fundamento da liberdade no sistema filosófico de Hans Jonas a partir do metabolismo; interioridade, teleologia, e transcendências do organismo primitivo: uma análise dos aspectos subjetivos da vida, em que analisaremos as consequências do pensamento anterior, isto é, a interioridade, e em que medida ela contribui para a compreensão da liberdade; e liberdade dialética, no qual compreenderemos como é possível falar de liberdade em um mundo marcado pela necessidade.

Se analisarmos, como Jonas fez, que herdamos da Modernidade uma ontologia da morte na qual todos os seres vivos foram submetidos aos princípios da res extensa, logo perceberemos que a reflexão sobre a ontologia da vida é de extrema importância devido às complicações que essa postura teórica trouxe para o campo ético. Ao remover da vida seu caractere de dignidade, o discurso do monismo materialista promoveu uma espécie de justificação de todo tratamento dos seres viventes (em especial da extra-humana) com um status ontológico como qualquer outro. Aliás, conceituar um termo como "vida" se tornara uma tarefa difícil em nosso tempo, e isso graças à definição que em geral adotamos de "matéria". Para o período moderno e o pensamento que se seguiu dele, a vida nada mais é do que um processo puramente mecânico de permutação material sem objetivos ou finalidades próprias. O problema, no entanto, é que essa concepção de vida não é suficiente para explicar a vida em sua totalidade uma vez que ela ignora os aspectos subjetivos da vida em nome de uma verdade objetiva. É por este motivo que precisamos alterar nossa concepção de vida e atribuir às demais espécies do planeta um processo que vai muito além

\footnotetext{
${ }^{1}$ O princípio vida tem duas principais edições: originalmente publicado em $1966 \mathrm{em}$ inglês sob o título de The Phenomenon of Life. Toward a Philosophical Biology, e posteriormente com o título de Organismus und Freibeit - Aufsätre zu einer philosophischen Biologie no idioma alemão (VIANA, 2014, p.393). Chamamos atenção para essas duas versões, pois ela se faz relevante para a presente pesquisa. No prefácio de 1972 desse mesmo livro, Jonas nos relata (2004, p.9) que o quarto capítulo não fora publicado na edição inglesa. Ora, fizemos tal distinção, pois a tradução na qual recorremos é a da versão alemã de 1973 e apenas ela traz em sua configuração o capítulo barmonia, equilibrio e devir conceito de sistema e sua aplicaśão ao terreno da vida, seção importante para o desenvolvimento da nossa pesquisa. Desse modo, devemos lembrar ao estudarmos o conceito de sistema na filosofia jonasiana a partir de O princípio vida estamos nos referindo à segunda edição da obra.
} 
da mecanicidade dos encadeamentos químicos que o constitui. Desse modo, estudaremos nesta pesquisa o conceito de vida orgânica para Jonas e suas implicações, tais como o conceito de identidade, e de liberdade aplicada ao organismo. Ora, de acordo com Jonas (2004, p.14), o estudo da liberdade é importante pois ela é o fio de Ariadne para interpretação daquilo que entendemos por vida. Assim, compreendemos que liberdade está intimamente conectada à vida, e a compreensão de uma nos ajuda na compreensão da outra. Nesse sentido, a pergunta que expressa a problemática que buscamos resolver é: como podemos diferenciar esses organismos da mera materialidade do mundo físico no sentido de podermos atribuir a uma classe de sistemas uma característica como a liberdade?

Antes de prosseguirmos com nossa pesquisa, precisamos ter claro em mente desde já o que Jonas entende por liberdade, ou nos espantaremos com a afirmação de que um ser apenas dotado com o metabolismo é já dotado de liberdade. Desse modo, quando, no decorrer do presente artigo, utilizamos o termo "vida", temos em mente um processo pelo qual um aglomerado de corpos materiais se distingue do reino da matéria pura através do metabolismo (JONAS, 2004, p.107), ou seja, a absorção de nutrientes do meio e a descarga de algum material para o mundo.

\section{UMA ANÁlISE DO QUE APARECE OBJETIVAMENTE DO SER VIVO A PARTIR DA LEITURA FILOSÓFICA DE JONAS DO SISTEMA METABÓLICO}

No prefácio da obra O princípio vida, Jonas afirma que “já o metabolismo, a camada básica de toda existência orgânica, permite que a liberdade seja reconhecida - ou que ele é efetivamente a primeira forma de liberdade" (JONAS, 2004, p.13). Isso implica que toda vida, isto é, um organismo possuidor de metabolismo, é um ser que carrega em si a forma mais primitiva de liberdade (que tem seu ápice no ser humano).

Mas o que exatamente Jonas tem em mente quando ele utiliza o termo "metabolismo" como definição do ser vivente? O termo alemão metabolismo é designado por Stoffweschsel e tem o significado de troca de matéria (COMÍN, 2005, p.44). Porém, esse conceito de metabolismo, quando tomado isoladamente não é o suficiente para definir o que é vida, e nos leva a dois problemas: a) se tomamos a definição de ser orgânico vivo pelo único critério do metabolismo, isto é, a capacidade de um agregado de matéria de absorver e ejetar substâncias fundamentais para seu funcionamento, podemos (e devemos) atribuir vida à máquina que absorve combustível e expele algum material que não lhe é mais necessário; b) além disso, o fato da vida orgânica estar com sua materialidade em constante transformação devido sua necessidade de nutrição, levaria a 
absurda afirmação de que em dois cortes temporais o organismo seria outro, não mantendo sua identidade como algo fixo. Os dois problemas, porém, não se encontram juntos, mas o segundo decorre da solução do primeiro.

Quando compreendemos troca de matéria com o meio, a analogia da máquina torna-se inevitável: afinal de contas, em que medida seria o ser orgânico diferente de um maquinário submetido à necessidade de absorver e expelir materiais?

A analogia da máquina, para Jonas (2004, p.98), não se sustenta como verdadeira, já que no caso do equipamento sem vida a identidade material é sempre a mesma, ou seja, o "metabolismo" (nesse caso, o "motor") não está envolvido na mudança de si mesmo no processo de troca de matéria com o mundo. Isso faz, segundo Jonas, a máquina se diferenciar do organismo, pois a primeira tem um sistema autoidêntico interno, já a segunda uma identidade material que está em constante mudança.

Além disso, devemos levar em conta também que a máquina não precisa de uma autocontinuidade, uma vez que podemos desligar o motor e voltar a ligá-lo quando nos aprouver, que a equipamento continuará funcionando. Quando desativamos o maquinário por um período de tempo, sua permanência material no espaço e tempo permite que ele seja idêntico em todos os momentos (salvo se ocorrer uma intervenção externa à máquina que a altere de alguma forma), nos permitindo assim definir sua identidade como a "lógica do vazio A=A" (JONAS, 2004, 104). Do ponto de vista do que é material, átomos, cadeiras, espelhos, etc., mantém sua identidade apenas pelo "estar aî" (JONAS, 2009, p.268). Assim, se olharmos um agregado de substâncias mais complexas, como uma bactéria através de um olhar analítico, veríamos que o organismo tem os mesmos traços gerais que as outras matérias (JONAS, 2012b, p.14). Isto quer dizer que somos levados a concluir erroneamente que um ser orgânico e uma gota de água adquirem o mesmo valor ontológico. Em outras palavras, a existência atual dos objetos não depende de nada além do que eles são agora, ou seja, da identidade material, e não precisam de autoafirmação a todo momento (JONAS, 2009, p.268).

Sistema aberto e sistema fechado ${ }^{2}$, eis os conceitos fundamentais para compreender como Jonas distingue o ser vivo, dotado de liberdade, da mera matéria morta. Enquanto o primeiro é marcado pela alteração do seu constituinte material, o segundo tem sua identidade definida por

\footnotetext{
2 Atribuir aos seres vivos a reflexão na qual eles são tomados como sistemas aparece primeiramente na Teoria Geral dos Sistemas de Ludwig von Bertalanffy, a qual Jonas menciona em seu O princípio vida, e a partir da qual funda sua ontologia do organismo. Devemos lembrar aqui que há diferenças fundamentais entre as duas teorias, como a mais crucial delas: "Diferentemente de Bertalanffy, Jonas insiste no fato de que o significado formal do organismo - que é sua característica ontológica particular - não pode ser completamente explanada pelas fórmulas matemáticaquantitativas de um de um sistema” (TIBALDEO, 2015, p.20, tradução nossa). Como já exposto na introdução, este importante conceito da filosofia do organismo jonasiana não está presente na edição The Phenomenon of Life, mas apenas na versão alemã de 1973.
} 
sua materialidade, por seu estar aí. Mas antes de nos aprofundarmos nessa distinção, precisamos antes de mais nada, compreender o que Jonas entende por sistema.

O objetivo de Jonas ao trabalhar o conceito de sistema em sua ontologia da vida é resolver o problema deixado pelo monismo materialista, a saber, a diferença entre material vivo e material morto. Em outros termos: como explicar a existência de uma unidade que se destaca da matéria que é em si mesma destituída de interesse como uma forma de ser que tem em si uma finalidade intrínseca? Jonas consegue encontrar essa diferenciação identificando um comportamento diferente do sistema do corpo vivo do que nos sistemas do restante da matéria.

O filósofo define um sistema da seguinte maneira: "Quais são as características gerais de um sistema? 'Sistema' significa a união de um sistema de coisas, uma combinação (um sistema é uma unidade de uma pluralidade)" (JONAS, 2012a, p.201, tradução nossa). Isso quer dizer, de acordo com Jonas (2004, p.76), que o conceito de conjunto determina o sentido de sistema e pressupõe uma pluralidade que esteve junta pela relação do conjunto, e que não pode existir de outra maneira que não seja por esta relação. É nesse sentido que Viana afirma que para Jonas “o organismo vivo é entendido como um sistema cujas partes são organizadas por um princípio elevado” (VIANA, 2014, p.394). Mas definição ainda não nos é suficiente para compreender como o conceito de sistema pode dar unidade ao conceito de vida. Para o entendermos melhor, de acordo com Jonas, precisamos analisar os critérios adotados para a definição dessa unidade. As regras precisam ser definidas uma vez que o princípio da semelhança pode ser usado de acordo com a vontade do indivíduo que está observando o sistema, já “os princípios do fundamento ou das condições, obriga que o pensamento assuma certos compromissos" (JONAS, 2004, p.76). Seguindo essa perspectiva Jonas argumenta que em uma poça de água as diversas gotas deixam de existir como uma pluralidade para se tornarem uma unidade (a própria poça de água). No entanto, a gota ainda é um sistema formado pelas moléculas, pois ela comporta um número finito de moléculas com a característica de gota. Isso implica que não pode existir um sistema infinito, mas também tampouco pode existir um sistema extremamente simples. Em suma, "o sistema é um meio termo entre o absolutamente uno e o infinitamente plural" (JONAS, 2004, p.77), o que permite nos dizer (pela finitude do sistema) que ainda existe um fora que distingue o sistema do restante do mundo ${ }^{3}$. No entanto, segundo Jonas (2004, p.76), para o ser, esta condição precisa significar que ele está conectado a si mesmo, ou seja, ele forma uma união de dependências, e quando alcança esta ligação, ele é um todo, e não apenas uma multiplicidade.

\footnotetext{
${ }^{3}$ Nesse sentido, o universo é um sistema na medida em que as forças que o constitui atuam em um campo finito de ordenação (JONAS, 2004, p.76). Nessa perspectiva, para Jonas (2012b, p.201), o sistema solar seria um sistema enquanto o Sol mantiver os corpos que o circundam unidos, de maneira que o movimento dos corpos dependa do movimento de outros.
} 
Isso implicaria que da mera existência desse sistema já resultaria na conservação e na permanência do equilíbrio dessa organização sistêmica.

A dinâmica do equilíbrio e desequilíbrio nos leva ao conceito de devir, pois "a ocasião para o novo está presente na mesma medida em que o desequilíbrio, e que o aproveitar desta ocasião, isto é, o efetivo devir de algo novo, nasce unicamente do dinamismo do desequilíbrio" (JONAS, 2004, p.79). É justamente a oscilação permanente e irregular que permite que o sistema funcione.

O dinamismo do desequilíbrio impele o conjunto dos corpos ao movimento. Mas que é um movimento na teoria dos sistemas jonasiana? Ora, movimento é o retornar periodicamente de estados idênticos. Jonas afirma que o período é o tempo próprio do sistema. Segue-se disso que só pode existir história enquanto este processo de equilíbrio e desequilíbrio estiver ocorrendo. Ou seja, quando o sistema está se construindo ou se desfazendo, ele permanece em movimento, mas enquanto o sistema é sempre constante, não é dotado de história, de modo que "os aspectos da harmonia e da historicidade se excluem mutuamente" (JONAS, 2004, p.79). Um conceito de sistema sem historicidade só poderia ser aplicado em um conjunto perfeitamente harmônico, o que pode ser apenas uma aparência do referencial humano ${ }^{4}$, ou seja, como se alguns movimentos fossem imperceptíveis, mas, no entanto, existentes, quebrando assim a harmonia perfeita do sistema. No entanto, nesse caso devemos buscar um ponto mais abaixo do sistema nãoharmônico em que nos permita apontá-lo como uma unidade apesar de sua movimentação, de modificação inerente a si. Ora, do constante equilíbrio e desequilíbrio que garantem a unidade do sistema e sua permanência como idêntico a si mesmo na multiplicidade espacial, podemos afirmar que voltada ao campo dos seres vivos, a dinâmica incerta tem uma singularidade, pois para a vida o constante decaimento do sistema representa a dimensão finita de si mesma, ou seja, a própria morte (JONAS, 2004, p.82).

É, portanto, no decaimento que Jonas identifica o ponto que permite notar que mesmo através do movimento há uma unidade no sistema orgânico que mantém o ser vivo como uma identidade diferençável de outros seres do mundo. É por isso que ao falar do sistema aberto do organismo Jonas afirma que o manter de um sistema orgânico é:

Um meio termo entre o devir e o perecer, entre o ser e o não ser. Um meiotermo, porém, não no sentido indiferente de ele simplesmente se encontrar entre duas coisas, e sim no sentido crítico de manter o equilíbrio, de que pelo fato de existir ele detém a queda mas que no próprio exercício de sua função

\footnotetext{
4 Ainda tomando o exemplo do sistema solar, podemos compreendê-lo como um sistema com historicidade na medida mesma medida em que os corpos celestes descrevem uma espiral em direção ao sol, deixando assim o sistema sempre em decaimento, ao contrário do sistema harmônico no qual os planetas descreveriam trajetos perfeitos e inconstantes ao redor da estrela solar.
} 
repetidora, ele não pode deixar de ir caindo, já que só pela queda pode conseguir os meios termos para detê-la, tendo a cada movimento representar o 'meio' em um ponto mais rio abaixo (JONAS, 2004, p.82).

Dentro dessa perspectiva, cada um dos momentos do ser vivo acrescenta-lhe algo sempre novo, o que não acontece no fora do âmbito dos seres metabólicos, pois eles são sempre definidos por seus elementos simultâneos fazendo que seus estados sejam a expressão contínua de uma multiplicidade espacial que é definida de uma vez por todas (JONAS, 2004, p.81). É nesse sentido que Jonas afirma que o conceito de equilíbrio é como um correspondente moderno do conceito de harmonia da antiguidade. Ou seja, o sistema, justamente pelo fato de existir, detém em si sua própria queda. Por esse motivo no campo da vida esse aspecto do sistema tem um caráter particularmente adequado, uma vez que o vivente é sempre obrigado a sucumbir, e é a cada momento empurrado para a morte (JONAS, 2004, p.82).

A vida, isto é, um sistema aberto:

Diferentemente do sistema fechado da mecânica clássica, [...] não é expressão de um equilíbrio existente, mas sim o constante estabelecimento e restabelecimento do equilíbrio. O fato de o restabelecimento ser necessário está ligado à própria abertura, por exemplo, no caso do metabolismo, à perturbação do equilíbrio pela sua carência que ocorre naturalmente [...]. O tipo de periodicidade que ocorre aqui já não é o de um ciclo de estados equivalentes, mas sim o oscilar entre o ser e o não-ser, um equilíbrio móvel de devir e perecer, e neste sentido um acontecer autêntico (JONAS, 2004, p.85, grifo nosso).

Chegamos aqui aos fundamentos da teoria jonasiana que nos permitirá encontrar traços no organismo primitivo, pois é a partir dessa oscilação entre ser e não-ser que será possível estabelecer a intencionalidade (portanto, liberdade) orgânica. Ora, é devido ao estado dinâmico da metabolização do sistema que o organismo altera substancialmente a si mesmo. Para que o sistema funcione, seu desequilíbrio (falta de nutrientes) precisa rapidamente ser "restaurado" ao estado de equilíbrio "original”, o que leva o ser orgânico a buscar no mundo a matéria necessária para sua sobrevivência.

Esse fato de mutação de si do ser vivo exige que a identidade não possa ser mais encontrada na matéria uma vez que ela é mera transitoriedade e está sujeita às mudanças constantes. O processo pelo qual organismo tem sua identidade não depositada na materialidade é chamado por Jonas de "revolução ontológica" (JONAS, 2004, p.104). Nessa perspectiva, Moura 2015, p.582) afirma que a identidade de si mesmo é um caráter ontológico que se mantém operante ante a modificação da matéria, fazendo a liberdade manifesta surgir como forma independente do reino material. Percebemos desse modo como Jonas resolve o problema da identidade, visto que a matéria transicional é sempre o pano de fundo no qual o organismo 
constitui a si mesmo. Em outras palavras, é a unidade do sistema que permite identificar um organismo como um "si mesmo". Do conceito de "si mesmo" da existência orgânica podemos identificar que a identidade da vida nos aparece em dois horizontes: "um interno - o tempo como a fase seguinte de sua existência para a qual se dirige; e um externo - o espaço - como lugar do outro, do mundo, igualmente presente e da qual depende a continuidade de seu ser" (MOURA, 2015, p.583, grifo nosso). É a identidade interna do organismo abre a dimensão da interioridade, e é aí que se encontra a intencionalidade orgânica.

\section{INTERIORIDADE, TELEOLOGIA, E TRANSCENDÊNCIA DO ORGANISMO PRIMITIVO}

Como observamos na seção anterior, Jonas aponta para a existência da interioridade orgânica, que é uma expressão individual do isolamento do organismo em relação ao mundo, e tem sua manifestação mais acentuada nos processos de transcendências temporal e espacial. Essa identidade do organismo, tida como a identidade ontológica, tem seu ápice na dimensão da interioridade. Assim sendo, todo organismo dotado de metabolismo tem interioridade ou subjetividade, que inclui os encontros que ocorrem dentro da mesmidade sentida, ainda que essa sensação seja fraca (JONAS, 2004, p.109). Por este motivo o estudo da teoria sistêmica aplicada ao organismo é de vital importância para compreendermos o conceito de vida nas considerações de Jonas, pois apesar de ser objetivamente observada, das consequências dela o filósofo alemão retira os aspectos sentidos do próprio corpo vivo e assim chega ao conceito de subjetividade.

Utilizamos acima o termo "subjetividade", porém, há um ponto importante a ser lembrado a essa altura: de acordo com Lopes (2010, p.59-60), quando Jonas utiliza a palavra "subjetividade", ele não se refere à uma subjetividade mental, mas em uma espécie de gradação de subjetivos configurada de uma maneira que se uma subjetividade mental tiver que descer alguns níveis na gradação, chegará um momento em que não será possível encontrar um sujeito. Isso não quer dizer, no entanto, que não exista intencionalidade ou interioridade nessa subjetividade, ainda que não esteja mais dentro do campo mental. A esse aspecto gradativo da subjetividade, Jonas dá o nome de transcendência imanente, que é uma espécie de "espírito invisível" presente em todos seres vivos, e apesar de ser "invisível", é o que mais se vê, pois corresponde ao "eu” da liberdade (OLIVEIRA, 2015, p.45).

Para esclarecer ainda mais esse termo, se faz necessário diferenciarmos dois termos aqui: ipseidade e psique. De acordo com Jonas (2006, p.139), enquanto a psique está presente no organismo desde sua camada mais básica até as existências elevadas, a ipseidade é encontrada em 
seres ainda não conscientes, mas que estão mais "evoluídos" no processo de gradação da subjetiva. Assim sendo, nos dizeres de Lopes, a psique para Jonas "encontra expressão em qualquer forma de impulso como tal, e a outra [ipseidade] se refere ela sim à esfera propriamente da individualidade, onde então já se pode falar de um sujeito” (LOPES, 2010, p.60). É papel da psique e não da ipseidade carregar a interioridade orgânica. Nesse contexto, "o que Jonas compreende como 'subjetividade em estado latente' poderia ser traduzido em 'subjetividade ainda exteriorizada', isto é, uma estrutura finalista ainda não consciente, como acontecerá no espírito humano" (VIANA, 2015, p.572).

Para não pensarmos que o termo subjetividade tem uma relação direta com o que comumente entendemos por ter uma subjetividade, precisamos levar em conta que a esfera subjetiva em Jonas está além da existência cerebral ou neuronal e vai dos mais elevados graus da vida até os primitivos estágios dos organismos através do que Jonas chama de "salto qualitativo" (JONAS, 2010, p.32). Mais ainda, Jonas (2010, p.19) chega a dizer que a subjetividade é um fato empírico (o aparecimento da vida a partir de arranjos químicos-morfológicos da matéria), porém não o é o horizonte interno que se abre a partir daí.

Em suma, o ser vivente parte da troca química de matéria com seu entorno e com isso define os limites espaciais da sua identidade, mas ao fazê-lo, o organismo abre em si a camada subjetiva da vida. Nesse sentido, a identidade orgânica junto com o metabolismo é responsável por trazer à luz a dimensão subjetiva do ser vivente.

\subsection{INTERIORIDADE ORGÂNICA}

Partindo do conceito de interioridade orgânica, percebemos que "por estar aberta para fora, a identidade interior é o polo subjetivo da comunicação com o mundo" (MOURA, 2015, p.579). A abertura do organismo para o mundo, isto é, sua transcendência para buscar fora de si a matéria necessária para a autoconservação, é ela toda a iniciação da identidade ontológica, que é, por sua vez, o início do subjetivo no ser orgânico, isto é, da interioridade teleológica. Em suma, a independência da forma em relação à matéria (primeira expressão da liberdade orgânica), já forma a possibilidade de interioridade, e a interioridade se efetiva no real ato de transcender no espaço e no tempo. Mas o que é essa interioridade? Vejamos a definição de Jonas:

Quer chamemos esta interioridade de sensação, sensibilidade e resposta à estímulos, busca ou tendência - em certo grau (mesmo infinitesimal) de percepção sensitiva ela obriga o interesse absoluto do organismo em sua própria existência e sua preservação - isto é, ela é "egocêntrica" -, ao mesmo tempo que supera o fosso qualitativo em relação ao resto das coisas através de 
modos de relação eletiva, que com sua peculiaridade e urgência substituem para o organismo o lugar da integração geral das coisas materiais em sua vizinhança física (JONAS, 2004, p.109).

Isso quer dizer que a existência orgânica em sua dimensão de interioridade, através da atividade metabólica, expressa seu interesse pela vida a partir da intencionalidade. Ou, como nos mostra Moura 2015, p.579), não pode existir organismo sem interioridade, nem interioridade sem teleologia, de modo que interioridade e teleologia estão intimamente conectadas. Para Jonas (2004, p.109) o horizonte aberto do organismo significa afetabilidade e espontaneidade, de modo que ao se expor ao exterior, o organismo chega ao exterior, pois é assim, isto é, sendo sensitiva, que a vida é ativa. Segundo Weber (2002, p.189), a própria afetabilidade, na filosofia do organismo de Jonas já é um eu rudimentar, pois o que é sentido é sempre sentido a partir de um eu.

Ora, podemos ver que é justamente nesse ponto que Jonas fundamentará intencionalidade orgânica, isto é, na abertura com o mundo que inclui uma intencionalidade em preservar a vida pelo metabolismo, que é, essencialmente, uma abertura para a exterioridade. E nesse ponto relembramos as investigações de Jonas a respeito da atividade metabólica, pois como nos lembra Lindberg (2005, p.8), é o metabolismo que é o responsável pela divisão entre interioridade e exterioridade, de tal modo que a atividade metabólica produz interioridade e exterioridade de maneira inter-relacionadas, não existindo, portanto, primeiro um e depois o outro. Podemos comprovar esse ponto de vista se lermos ao texto de Jonas e percebermos que na metabolização, ao ser afetado por algum estranho, o ser que é afetado sente a si próprio de maneira tal que sua identidade (mesmidade) é definida pelo que vem de fora. Isso quer dizer que é pela relação do mundo com o organismo que a vida sente a si mesma, fortalecendo assim o aspecto da interioridade, ou, "sua mesmidade e como que iluminada pela outridade do fora" (JONAS, 2004, p.109).

Podemos dizer que há uma dinâmica de passividade e atividade que pode ser percebida em dois níveis (aqui apenas didaticamente separados): do metabolismo enquanto troca de energia com o meio, e da interioridade enquanto constituição do "si mesmo" e efetivação da liberdade no organismo. Esse é o aspecto passivo do organismo, que é sempre afetado pelo que chega do exterior (DUARTE, 2015a, p.55). Nesse ponto já é possível destacar o caráter de liberdade necessitada, na medida em que o organismo depende do que afeta e da afetabilidade que atua sobre ele para afirmar a mesmidade no mundo. É a partir daqui que Jonas pode buscar no ser vivo sua subjetividade, no sentido de encontrar um "eu" que faz uma oposição ao "mundo", uma mesmidade que é oposta a tudo que é a outridade, ainda que essa mensagem seja fraca e obscura (JONAS, 2004, p.109). 
A interioridade, só pode ser afirmada a partir da identidade do organismo, isto é, da sua separação com o mundo no sentido de diferenciação de sistemas, pois enquanto a interioridade é experimentada pelo organismo, a identidade é que traça os limites entre a mesmidade e a outridade. A interioridade é, a experiência interna da identidade em um sistema monista integral. Dentro dessa perspectiva, identidade e interioridade se complementam, e uma não pode existir sem a outra, de modo que formam uma unidade no organismo vivo.

Dito isso, precisamos nos atentar para o fato de que esse reconhecimento do organismo como um ser dotado de identidade e interioridade só o é através do processo da atividade metabólica, que tem sua expressão nas transcendências da vida, na transcendência temporal e espacial, que implicam em uma intencionalidade, teleologia, ou ainda, em uma liberdade do organismo. Se autoafirmar-se na teoria Jonasiana é viver como desejo (JONAS, 2004, p.14), então podemos identificar nas transcendências a intencionalidade orgânica e o início do ato de liberdade como um meio de conservação.

Desse modo chegamos ao polo subjetivo da vida que aparece graças ao autoisolamento do orgânico, e vemos assim que "deparamo-nos aqui com a estrutura dialética que perpassa todos os caracteres ontológicos da vida, fazendo-a aparecer de todos os lados como um paradoxo da existência material (JONAS, 2004, p.110). Ora, a vida sente o estranho pelo caráter passivo da transcendência, e é através dela que ela confirma sua interioridade. Se acima utilizamos o termo liberdade foi para mostrar que a vida não é marcada por forças puramente cegas e mecânicas. Podemos ver que a interioridade orgânica aparece de dois modos: o passivo, marcado pelo intruso que afeta o ser orgânico; e o ativo, marcado pela liberdade necessitada do organismo que busca autoafirmar-se através da autotranscedência temporal e espacial.

\subsection{ASPECTOS TELEOLÓGICOS ${ }^{5}$ DO ORGANISMO PRIMITIVO E SUA RELAÇÃO COM A LIBERDADE.}

Uma vez que vimos que a interioridade implica em uma intencionalidade, estudaremos no decorrer dessa subseção a teleologia orgânica e sua manifestação no ser metabólico. Mas o que é teleologia para Jonas? Como pode a matéria, algo em si mesmo indiferente em teleologia, ter em suas formações uma intencionalidade?

\footnotetext{
${ }^{5}$ Teleologia e intencionalidade podem ser tomados como sinônimos. No entanto, segundo Lindberg (2005, p.11), quando Jonas adota o termo teleologia ao invés de intencionalidade, ele tem em mente três fatores: intencionalidade é um termo que pode ser incluído dentro do termo teleologia; o termo teleologia 'prepara o terreno' para o campo ético, ao qual Jonas leva sua filosofia do organismo; e o terceiro motivo que é incluído pela comentadora, seria que teleologia permite um diálogo com o século XIX, que é a motivação mais ou menos secreta de todas fenomenologias da vida. De qualquer modo, o primeiro e o segundo fator são importantes para nosso trabalho, pois eles nos mostram como intencionalidade e teleologia podem ser utilizadas como sinônimo
} 
Segundo Duarte (2015a, p.54), Jonas entende teleologia de duas formas: teleologia como sendo imanente ao organismo, ou como teleologia transcendente, que precisa de uma entidade exterior no processo com seu propósito exterior a ser executado. Jonas adota para sua filosofia do organismo a teleologia imanente, a qual é expressa pela intencionalidade da vida orgânica de permanecer na existência (DUARTE, 2015a, p.54).

Para Jonas (2004 p.25), intencionalidade, isto é, a inclinação para um objetivo, ocorre nos seres vivos de uma maneira manifestamente subjetiva, mas que também ocorre de modo objetivo e causal pelo processo metabólico. Teleologia é, para Jonas, um movimento do ser em relação à sua matéria (LINDBERG, 2005, p.11), expressando assim sua conexão com a liberdade como sendo independência da forma em relação ao material.

Contudo esse movimento do metabolismo de "causalidade é teleológico e não unicamente mecânico" (WEBER, 2002, p.188, tradução nossa). Percebemos assim que não seria possível sequer reduzir o organismo aos processos químicos nesse contexto, pois tal redução pressuporia o desconhecimento da natureza teleológica da causalidade interna do ser orgânico. Nesse sentido, a teleologia para Jonas pode ser concebida de modo que o:

Universo que acolhe finalidades desde o seu núcleo mais ínfimo, é a própria concepção de um finalismo no interior do próprio vir-a-ser da natureza; uma espécie de finalismo que [...] [se insere] na perspectiva de um mundo em processo (LOPES, 2010, p.61).

Isto quer dizer que o mundo tem em si a capacidade para a teleologia da vida. Nas palavras de Jonas (2004, p.26), as causas finais precisam ser admitidas dentro do conceito causalidade universal. Essa maneira de Jonas conceber a teleologia como algo possível dentro do próprio reino material é chamada de "neo-finalismo" (LOPES, 2010, p.60). O ser orgânico é, portanto, um ser teleológico, pois suporta em sua estrutura básica a capacidade para viver segundo objetivos.

O organismo ao metabolizar realiza um ato exclusivamente seu, que impulsionado pela necessidade vital, realiza a liberdade no encontro com o mundo e com o mais-além. Em suma, podemos dizer que para Jonas (2004, p.108), os dois modos de transcendência orgânica ocorrem a partir da separação entre o si mesmo e o mundo pelo processo metabólico. A afirmação anterior é de grande importância para a nossa pesquisa, pois é neste campo de transcendência pelo metabolismo que encontraremos o ato de liberdade e de necessidade da vida orgânica.

Essa transcendência infinita, esse voltar para-si-mesmo, é o sentido fundamental de sua atividade teleológica. A explicação de Jonas do "ter-omundo" mostra como teleologia [...] atravessa a distância através de uma 
abertura e segue para si mesma novamente. Teleologia é, para Jonas, a lei da experiência que revela o espaço-tempo concreto" (LINDBERG, 2005, p.12, tradução nossa).

A citação acima mostra o caráter de continuidade da transcendência, de modo que o organismo se vê sempre obrigado a realizá-la, isto é, de transcender pelo tempo e pelo espaço biológico. Ora, Jonas afirma que na troca de matéria com o meio, "a forma viva tem que dispor de matéria, e ela encontra fora de si, no 'mundo' estranho” (JONAS, 2004, p.108). Segundo o pensamento jonasiano, o interesse do "si mesmo" de adquirir matéria do mundo é um encontro com a realidade externa, o que faz o organismo abrir seu ser para a transcendência. O que Jonas entende por transcendência? Ora, "quando falamos de transcendência da vida, queremos dizer que ela mantém um horizonte, ou horizontes, além de sua identidade puntiforme" (JONAS, 2004, p.110). Esse processo de transcender a vida é uma face do processo metabólico. Mas por que atividade metabólica e com ela a transcendência do organismo ocorrem? É pela necessidade de buscar nutrientes para manter a subsistência que a vida precisa abrir-se sempre para fora no espaço, e para um mais-além no tempo.

O mundo é para o ser orgânico um "um horizonte aberto pelo mero caráter transcendente da carência" (JONAS, 2004, p.108), e a revolução ontológica tem como finalidade ter-o-mundo para a sobrevivência do organismo. O fundamento da vida está no ato de autotranscender, que nos estágios mais avançados do ser vivo, também se desenvolve de modo mais complexo (JONAS, 2004, p.109). Esse modo de buscar no mundo o material para sua existência, ou ainda, o direcionamento externo do organismo em relação ao co-presente, é chamado de espaço biológico, ou seja, quando o organismo encontra em seu externo algo que é potencialmente seu (DUARTE, 2015a, p.56).

A forma de transcendência encontrada até aqui está dentro do horizonte espacial, isto é, ela ocorre no processo em que o si-mesmo, ou seja, a identidade do organismo, que através do autotranscender quer ter-o-mundo no espaço simultâneo. No entanto, como nos mostra Jonas (2004, p.110), também há o horizonte temporal, em que o autointeresse da vida pela sua preservação está marcado por um interesse projetado para o futuro próximo. Ora, enquanto a transcendência no horizonte espacial implica em uma transcendência sempre para fora, no temporal, a transcendência ocorre interiormente. Mas o que é, exatamente, a transcendência em seu aspecto temporal? Ela é "o estar-iminente daquele futuro mais próximo, para onde em cada momento a continuidade orgânica está a caminho para satisfazer a carência precisamente deste momento" (JONAS, 2004, p.110). No autoisolar-se do mundo, o organismo não o faz de maneira completa, caso contrário, ele perecerá. Mas é por meio desse não-completo isolamento 
que o ser orgânico encontra sua interioridade. Isto é, essa dupla face da transcendência ocorre para dentro (dimensão temporal), e para fora (dimensão espacial):

\begin{abstract}
Assim como seu aqui estende-se para o ali, assim também seu agora estende-se para o logo-mais, e a vida se encontra ao mesmo tempo nos dois horizontes "além" de sua própria imediatez. Ou mesmo: ela só olha para fora porque através da necessidade de sua liberdade olha para a frente, de modo que a presença no espaço por assim dizer se clareia ao ser iluminada pelo logo-mais no tempo, ambas passando para a realização e também apara a decepção (JONAS, 2004, p.110).
\end{abstract}

Isto é, o organismo está projetando seu interesse na vida também para um futuro próximo, um futuro pelo qual ele está metabolizando a matéria em seu entorno para sobreviver aos diversos riscos que a vida apresenta consigo. Jonas (2004, p.110) também argumenta que é pela relação transitória entre forma e matéria que esse interesse da vida por se manter viva se manifesta, isto é, a fase interior do organismo que se estende até a seguinte, é a que constitui o tempo biológico, um correspondente ao tempo do sistema no mundo orgânico do qual já falamos. A abertura do organismo para o mundo, ou para o não-ele-mesmo, corresponde ao material necessário para a constituição biológica do ser orgânico.

É a transcendência do ser orgânico que implica tanto seu caráter de liberdade, quanto de necessidade. Vimos que esse processo ao qual está a vida obrigada a se submeter para manter sua existência não se limita somente ao ser necessário do organismo, como também atinge sua esfera de liberdade. Mas em que sentido é possível de falar em liberdade em um mundo marcado pela necessidade?

Antes de respondermos à indagação anterior, buscaremos conceituar necessidade no pensamento de Jonas, para que possamos compreender melhor a liberdade no organismo primitivo. O que Jonas entende por necessidade? A necessidade seria a cadeia causal do mundo, o jogo de forças da matéria que no campo da vida determina certas regularidades, a saber, a obrigação da nutrição e a obrigação de evitar a morte (WOLIN, 2003, p.172). Se para a tradição moderna o metabolismo era apenas um jogo de reações químicas que impulsionava a vida sempre para frente, mas sem nunca impor finalidade a ela, para Jonas esse dever do organismo representa sua própria manifestação de liberdade. O que há no orgânico é uma coexistência entre liberdade e necessidade, o que garantiria a unidade psicofísica do organismo. Não se trata, portanto, de entidades separadas e incomunicáveis em que necessariamente, excluir-se-iam mutualmente, mas da manifestação do orgânico que mostra seus dois modos de existir, um pelo poder, e outro pelo dever. 
Nesse sentido, ao afirmarmos que o organismo é dotado de liberdade, queremos dizer que ao realizar a fotossíntese, por exemplo, uma planta está exercendo sua liberdade, do mesmo modo que esta é obrigada a fazer, pois se não o fizer irá perecer. Em outras palavras, necessidade e liberdade existem simultaneamente. À relação entre o ser livre e necessário, Jonas dá o nome de "liberdade dialética" (JONAS, 2004, p.107). Desse modo, o orgânico tem o poder de fazer, mas não o tem para omitir, ou seja, o poder significa dever na medida que o importante para o organismo é manter seu ser. Porém, devemos lembrar aqui que para Jonas (2009, p.267), o ser do organismo é seu próprio fazer, e, posto que a condição desse fazer não depende apenas do organismo mesmo, mas do favorecimento de um ambiente que pode ser outorgado ou recusado, a ameaça de deixar de existir habita com a existência orgânica desde o seu surgimento. Se estabelece aqui a indissolúvel relação entre a vida e morte, visto que "a vida é mortal, não apesar de ser vida, mas precisamente porque é vida segundo sua mais primitiva constituição" (JONAS, 2004, p.15, grifo nosso), o que torna a vida e a morte indesatáveis uma da outra, tal como a liberdade e a necessidade, o espírito e a matéria. A vida não existe, dentro desta perspectiva, sem a morte, pois o orgânico só mantém seu ser devido sua negação à morte, porém, estamos de acordo com Viana (2015, p.571) quando o comentador afirma que a morte é uma negação radical do ser, e mesmo assim a vida se encontra entre o ser e o não-ser por ela ser instável e estar oscilando entre a existência e não-existência. É por isso que o ser orgânico precisa se afirmar a todo momento seja no tempo ou no espaço, para manter sempre distante o seu oposto.

Ser, isto é, existir enquanto organismo metabolizante, é viver em risco, de maneira que a liberdade se encontra sempre como uma oposição à vida a tal ponto que a vida precisa manter-se continuamente com seu esforço e suas aberturas, tanto no espaço, quanto no tempo, para manter-se. É exatamente por isso que devemos lembrar a afirmação de Jonas no prefácio do O princípio vida, na qual o autor afirma que "ser, em vez de um estado, passou a ser uma possiblidade imposta, que continuamente precisa ser conquistada ao seu contrário sempre presente, o não-ser, que inevitavelmente terminará por devorá-lo” (JONAS, 2004, p.15, grifo nosso). Liberdade e necessidade, nesse sentido, estão correlacionadas à vida e à morte.

\section{CONSIDERAÇÕES FINAIS.}

Apresentamos como o metabolismo, que é elemento fundamental da vida, nos permite encontrar a liberdade orgânica. Dentro dessa perspectiva, buscamos analisar o conceito de metabolismo e a identidade do sistema aberto, para que então pudéssemos estudar a interioridade 
orgânica. Foi a partir do conceito de sistema aberto que analisamos a diferença entre o organismo vivo e organismo não vivo dentro da filosofia jonasiana.

Enquanto identidade orgânica, o ser vivo abre na troca de matéria com o ambiente a dimensão interioridade. A vida passa a ser marcada pela relação entre o ser e o mundo, o "si mesmo e o "eu" que é portador daquela intencionalidade.

Aqui encontramos o ponto de união de liberdade e necessidade pela transcendência. Mas vimos também que existem diferentes níveis de liberdades no pensamento filosófico jonasiano, sendo a liberdade primitiva o modo germinal de ser da liberdade presente nos seres humanos e nos animais que se dividem em outras instâncias e ajudam a formar a totalidade dos seres mais complexos. A liberdade vai crescendo então de forma ascendente, dos organismos menos evoluídos para os mais evoluídos.

Uma vez que o pensamento filosófico de Jonas costuma se encontrar tão distante das nossas reflexões comuns, isto é, de atribuir aos organismos primitivos a liberdade, toda a dignidade é devolvida ao reino extra-humano, o que nos permite assim levar em consideração não apenas o pensamento ético antropocêntrico, como também uma nova ética biocêntrica.

\section{REFERÊNCIAS BIBLIOGRÁFICAS}

COMÍN, Illana Giner. Introducción a la edición española. In HANS, Jonas. Poder o impotência de la subjetividad. Tradução de Illana Giner Comin. Coleção Pensamento Contemporâneo. Barcelona/Buenos Aires/México: Paidós, 2005, p.13-70.

DUARTE, Michelle Bobsin; FILHO, Edgard José Jorge. Hans Jonas: Da crítica à ontologia da morte ao fundamento da ontologia da vida. 2015. 88 f. Dissertação (Mestrado) - Pontifícia Universidade Católica do Rio de Janeiro, Rio de Janeiro, 2013. Disponível em: $<$ http://www.maxwell.vrac.puc-rio.br/25625/25625.PDF>. Acesso em: 28 mar. 2015a

JONAS, Hans. Lecture 1. In: verlag, 2012a. Disponível em: < Major Systems of Philosophy. Freiburg: Rombach http://www.lettere.uniroma1.it/sites/default/files/649/jonas_dottorandi.pdf> Acesso em: 28 mar. 2015a.

Matéria, espírito e criação. 1. ed. Petrópolis: Vozes, 2010

2004.

O princípio vida: fundamentos para uma biologia filosófica. 2. ed. Petrópolis: Vozes,

O fardo e a benção da imortalidade. Trad. Wendell Evangelista Soares Lopes. Princípios. Natal, v.16 n. 25 jan-jun, p. 265-281, 2009.

2012b.

Pensar sobre Dios y otros ensayos. Trad. Ângela Ackermann. 3 ed. Barcelona: Heder, 
O princípio responsabilidade: ensaio de uma ética para a civilização tecnológica. Rio

de Janeiro: Contraponto, 2006

LINDBERG, Susanna. Hans Jona's theory of Life in the face of Responsibility. In: LEMBECK, Karl-Heinz; MERTENS, Karl; ORTH, Ernst Wolfgang (ed.) Phänomenologische

Forschungen. [S.1], 2005. Disponível em:

<http://www.helsinki.fi/teoretiskfilosofi/personal/Lindberg/Lindberg_HansJonas.pdf>.

Acesso em: 28 mar. 2016.

LOPES, Wendell. A renovação da teleologia em Hans Jonas: da biologia filosófica aos fundamentos da ética. Princípios. Natal, v. 17, n. 28, p. 47-70, 2010. Disponível em $<$ https://dialnet.unirioja.es/servlet/articulo?codigo=3582064>. Acesso em 23 mar. 2016.

MOURA, Sarah. Fundamentos da ética do futuro de Hans Jonas: os princípios vida e responsabilidade. In: CARAVALHO, Marcelo, et al. Filosofia Política Contemporânea: Coleção XVI Encontro ANPOF. São Paulo: ANPOF, 2015.

OLIVEIRA, Jelson. Responsabilidade. In: MORETTO Geovani, OLIVEIRA, Jelson, SGANZERLA, Anor. Vida, técnica e responsabilidade. São Paulo: Paulus; 2015. p. 15-74

TIBALDEO, Roberto Franzini. The meaning of life. Can Hans Jonas' philosophical biology effectively act against reductionism in the contemporary life sciences?. Humaniora.

Czasopismo Internetowe, n. 01, p.13-24, 2015. Disponível em:

$<$ http://humaniora.amu.edu.pl/sites/default/files/humaniora/Humaniora\%20 $\mathrm{nr} \% 209 / \mathrm{H}$ um_1_15_Tibaldeo.pdf>. Acesso em: 25 jan. 2015

VIANA, Wellistony Carvalho. O monismo integral de Hans Jonas contra o fisicalismo. In: Aurora, v. 26, n. 38, jan-jun p. 391-403, 2014.

. A filosofia da natureza de Hegel e Jonas. In: CARAVALHO, Marcelo, et al. Filosofia Política Contemporânea: Coleção XVI Encontro ANPOF. São Paulo: ANPOF, 2015.

WEBER, Andreas. Feeling the signs: The origins of meaning in the biological philosophy of Susanne K. Langer and Hans Jonas. Sign Systems Studies, v. 30 n.01, p. 183-200, 2002. Disponível em: <http://philpapers.org/rec/WEBFTS-2> Acesso em: 25 jan. 2016.

WOLIN, Richard. Hans lonas: el filósofo de la vida. In Los hijos de Heidegger. Hannah Arendt, Karl Lwith, Hans Jonas y Herbert Marcuse. Trad. María Candor. Madrid: Cátedra, 2003. 


\section{MAQUINISMO E FILOSOFIA: O NASCIMENTO DA QUESTÃO DA TÉCNICA}

Machinism and philosophy: the birth of the question of technique

\section{Eduardo Ramalho Rotstein}

Pós-doutorado no Programa de Pós-graduação em Filosofia da UFRJ;

Orientação Prof. Dr. Fernando Rodrigues

RESUMO: A questão da técnica tem despertado um interesse crescente do mundo intelectual nas últimas décadas em razão das transformações sociais e dos desafios éticos suscitados por inventos no campo da informática e da biologia. No intuito de iluminar os pressupostos do debate atual serão retraçadas, nesse artigo, a origem histórica da questão da técnica e das principais posições filosóficas assumidas diante da mesma. A partir das investigações históricas de Pierre-Maxime Schuhl descobre-se, em primeiro lugar, que a técnica entra decididamente na pauta do debate filosófico a partir de dificuldades originadas fora do âmbito intelectual, relacionadas à difusão das máquinas e ao nascimento da grande indústria no século XIX. Em segundo lugar, pode-se mostrar que foi sob a consideração dos efeitos ambíguos do maquinismo que se formaram as linhas mestras de interpretação que até os dias de hoje constituem a matriz da filosofia da técnica. Posições como otimismo ou pessimismo, humanismo ou fatalismo, nas quais incorre amiúde o questionamento mais recente da técnica, podem ser encontradas nas reflexões de escritores utopistas e de filósofos como Ernst Kapp e Oswald Spengler entre meados do século XIX e o início do século XX.

PALAVRAS-CHAVE: técnica; maquinismo; filosofia da técnica. 


\section{INTRODUÇÃO}

Quem lê a transcrição da célebre conferência "A questão da técnica", de Martin Heidegger, é amiúde tomado de perplexidade por não reconhecer na interpretação ali desenvolvida o menor traço do que o senso comum entende por técnica. Ocasionalmente, porém, o hermetismo do texto se rompe nas passagens que mencionam de modo vago um debate pré-existente a respeito do tema. Alude-se criticamente a posições como a de aceitação ou de recusa apaixonada da técnica, ou ainda à cegueira em se a considerar algo neutro. Fala-se também de uma representação corrente de técnica, dita "antropológica e instrumental", a qual serve de ponto de partida para a interpretação ontológica (HEIDEGGER, 1954/1962, p.6). No esforço de identificar os autores e rastrear as correntes com as quais Heidegger dialoga sob o véu do anonimato foi possível enfim ganhar uma visão de conjunto não apenas do meio intelectual ao qual reage a sua abordagem peculiar da questão da técnica, mas também do contexto mais amplo em que se deu o próprio nascimento desta.

A relevância do tópico histórico para os debates mais recentes acerca da técnica é endossada pelo fato, frequentemente constatado em diversas regiões fenomênicas, de que aquilo que participa na gênese de algo persiste até os momentos tardios de seu devir. Sendo assim, pretende-se aqui iluminar os elementos que configuram o campo atual da Filosofia da Técnica por meio de uma revisão tanto das condições históricas de nascimento da sua questão definidora quanto das posições teóricas primeiramente assumidas diante desta. Espera-se, por fim, que essa revista histórica possa contribuir para situar o pensamento de Hans Jonas entre as linhas-mestras que emanam da tradição.

\section{A QUESTÃo DA TÉCNICA E O PROBLEMA COM A MÁQUINA}

A questão da técnica teve o seu nascimento com a difusão da técnica maquínica pela Europa ocidental no início do século XIX. Essa declaração de nascimento num momento relativamente recente e bem preciso subentende que a questão da técnica, tal como está posta desde então até os dias de hoje, não equivale à interrogação "o que é a técnica?". Interrogação semelhante já havia sido feita na Antiguidade por Platão e Aristóteles em suas considerações sobre a téchne ${ }^{1}$. No entanto, o que faltava ali e parece ser fundamental para a formação da questão

\footnotetext{
1 A interrogação acerca da téchne entre os gregos está ligada, em linhas gerais, ao esforço de hierarquização das atividades humanas conforme o seu valor cognitivo. Trata-se de saber a que distância as téchnai se encontram, por um lado, do conhecimento científico (epistème) e, por outro, da empiria característica dos ofícios manuais. Também importa determinar se a formação do caráter ou exercício das virtudes éticas deixa-se pensar como técnica ou depende em algum grau de tal atividade. Em Platão encontramos a interrogação acerca da técnica nos diálogos Íon
} 
propriamente dita é o sentido de urgência. Este implica a convicção de que a técnica é um fator decisivo para a sorte do gênero humano sobre a terra; a convicção de que a história da humanidade está estreitamente entrelaçada com a do desenvolvimento técnico e, portanto, pensar a técnica é tarefa de primeira hora.

Da Antiguidade à Modernidade ocorreram mudanças significativas não somente no interior do fazer técnico, mas também, e paralelamente, no modo como o recepcionou o círculo restrito dos eruditos e pensadores. Em Maquinismo e filosofia examina Pierre-Maxime Schuhl a lenta transformação mental concluída no século XVIII graças a qual as artes mecânicas foram resgatadas do lugar depreciado a que até o fim da Idade Média haviam sido relegadas na oposição com as artes liberais. À luz da nova mentalidade, as artes mecânicas não mais deveriam ser identificadas com o penoso e rotineiro labor manual das classes servis, nem mais inteiramente dissociadas da investigação teórica e dos lazeres estudiosos, atividades consideradas pela tradição como as verdadeiramente dignas de um homem. Os moinhos de água e de vento, as soluções de engenharia obtidas por Leonardo da Vinci e as navegações de longa distância convenciam os sábios de que a ocupação com instrumentos e aparatos, embora envolvesse os procedimentos tateantes típicos de toda aplicação prática, não redundava na ignorância acomodada e autossuficiente dos ofícios rotineiros e, longe de atar os homens às tarefas materiais da vida, permitia-lhes um maior alívio de seu fardo (1938/1955, pp.39-45).

Surge assim a ideia de uma ciência capaz de diminuir os sofrimentos humanos através do melhoramento das técnicas, o ideal por assim dizer de "uma magia natural e benfazeja". Essa é a ideia de Francis Bacon, para quem o conhecimento da natureza e de suas leis dará aos homens o poder de subjugá-la; do mesmo Bacon que lhes quer ensinar a serem "os obreiros de sua própria fortuna, os artesãos de seu destino", e que "sonha com uma Nova Atlântida", na qual haveria "mil inventos maravilhosos" a tornar "a vida mais fácil e larga” (SCHUHL, 1938/1955, p.115f). Tal é também a ideia de Descartes, que embora baseie num "idealismo matemático" a sua concepção da nova ciência, entrevê nesta uma orientação análoga à de Bacon: aplicar as noções gerais da física a problemas particulares com vista ao bem de todos, buscar uma "filosofia prática", pela qual as forças e os elementos conhecidos pelo homem encontrarão um emprego benéfico (SCHUHL, 1938/1955, p.50).

No entanto, o otimismo crescente com que a atividade técnica foi recepcionada ao longo de quase quatro séculos começou a arrefecer com o nascimento da grande indústria no século XIX. Quando as máquinas - esses mecanismos de funcionamento autônomo que ainda numa

(2011), Górgias (1972a, 449d-452a, pp.279-289) e Philebo (1972b, 56b-58d, pp.403-411). Em Aristóteles, ela figura, entre outros, no capítulo primeiro do livro Alfa da Metafísica (1989, 981a) e no sexto livro da Ética a Nicômaco (1998, 1139a-1140b, pp.26-36). 
fase incipiente de desenvolvimento haviam feito Descartes sonhar com a liberação dos homens dos trabalhos pesados (SCHUHL, 1938/1955, pp.51f;116) - justamente quando as máquinas atingiram um nível de aprimoramento suficiente para o seu emprego generalizado, irromperam fenômenos que contrabalançavam os ganhos alcançados e abrandavam as expectativas nelas depositadas havia muito tempo. Nesse contexto de expansão da máquina e da indústria erguemse as primeiras vozes que, ao assumirem para si a tarefa de sanar as mazelas do progresso técnico, buscam consequentemente entender as causas do problema a partir de uma reflexão sobre o fenômeno técnico em geral.

Pode-se dizer, portanto, que a questão da técnica, enquanto inquirição teórica plenamente consciente da importância de seu objeto para a sorte da humanidade, nasce em meio à urgência em resolver dificuldades concretas suscitadas pelo progresso técnico. Antes do infortúnio das máquinas no século XIX havia entre pensadores da Modernidade apenas um deslumbramento diante das possibilidades técnicas, o que é por certo necessário, mas não suficiente para disparar um questionamento sério e radical. Com efeito, a técnica só se tornou uma questão para os filósofos porque a máquina havia se tornado um problema para a gente comum.

\section{A AMBIGUIDADE DA TÉCNICA NA ERA DAS MÁQUINAS}

Mas em que consiste propriamente o problema que deu nascimento à questão da técnica? Esse problema, evidenciado com a expansão das máquinas no século XIX, poderia muito sensatamente ser intitulado o problema da ambiguidade da técnica. Por um lado, o largo emprego das máquinas preencheu a expectativa, que alguns visionários do passado haviam depositado nelas, de que facilitariam as tarefas materiais da vida. Elas levaram a um incremento sem precedentes da produção de bens úteis e à diminuição de seu preço, tornando possível o abastecimento de um grande contingente populacional. Um dado levantado pelo economista político Werner Sombart revela o efeito quase prodigioso da introdução massiva das máquinas na vida europeia no século XIX. Desde o início da história europeia no século VI até o ano 1800 portanto em doze séculos - a Europa jamais havia ultrapassado a cifra de 180 milhões de habitantes. De 1800 a 1914, no período aproximado de um único século, a população europeia salta de 180 a 460 milhões (SOMBART apud ORTEGA Y GASSET, 1930/2016, p.120).

Essa abrupta proliferação de homens deve-se à diminuição da taxa de mortalidade conjugada ao aumento da de natalidade, ambos frutos da facilitação do acesso de bens à população; em suma: o maquinismo foi um fator decisivo, senão o principal responsável pelo crescimento do nível de vida da população europeia. Pense-se apenas que um homem de classe 
baixa habitando um centro urbano europeu no século XIX tem acesso a utensílios e víveres que na Idade Média estavam vedados a muito fidalgo, ou então noutros tempos eram privativos de uma elite.

Por outro lado, a expansão inédita das máquinas trouxe uma série de consequências desfavoráveis, que naturalmente não haviam sido previstas e para as quais tampouco se havia preparado. Tais prejuízos são percebidos com nitidez crescente no curso do século XIX, manifestando-se nos níveis material, social e moral. Ficaremos em apenas três exemplos dessas consequências indesejáveis a fim de dar uma ideia da multidimensionalidade do problema com a máquina.

A primeira e mais rapidamente sentida consequência do maquinismo foi a desocupação maciça dos trabalhadores concomitantemente a um incremento sem precedentes na escala de produção. Resultado: muitos bens despejados sobre um mercado com poucos consumidores, ou seja, crise de superprodução.

Outra consequência, pouco menos vistosa, foi a transformação no modo como desde há milênios se trabalhava. Houve, mesmo, uma degradação do trabalho. Diferente do artesanato, em que o artefato obedece e se conforma aos movimentos do trabalhador, no trabalho fabril este tem de se ajustar ao funcionamento do mecanismo, convertendo-se ele próprio numa espécie de autômato.

Mais grave é uma consequência insidiosa do maquinismo que parece nascer tão somente da natureza deste, sem maior participação de contingências exteriores como legislação trabalhista em vigor ou a ganância do patronato: A expansão das máquinas dá-se em um processo imperioso e irrefreável, o qual avança em cadeia sobre todos os níveis de produção, transformando paisagens e ameaçando ecossistemas até então intocados. Contudo, a onipresença paisagística da técnica esconde o fato ainda mais drástico de que as máquinas logo se tornaram o pressuposto da vida moderna, o fator sem o qual teria sido impossível a multiplicação sem precedentes da população e a manutenção desta num nível elevado de vida. Com a expansão das máquinas temse pela primeira vez a clara impressão de que os inventos são para os homens tão cogentes quanto uma necessidade natural, algo por relação ao qual eles se sentem em dependência vital. Se repentinamente as máquinas fossem suprimidas ou parassem de funcionar, o grande contingente populacional que se nutre e se mantém por elas teria a sua vida literalmente impossibilitada.

\section{POSIÇÕES NA FILOSOFIA DA TÉCNICA}


Eis então a ambiguidade da técnica tornada patente com a expansão da máquina no século XIX. A máquina garante um crescimento inédito na quantidade e na qualidade de vida da população, enquanto lhe traz prejuízos e dificuldades igualmente inéditas, cujos exemplos são as crises de superprodução, a degradação do trabalho e a dependência vital em relação à técnica. Mas como o problema da ambiguidade refletiu-se na questão da técnica? Ou mais precisamente: Quais posições foram assumidas no debate teórico sobre a técnica suscitado pelo problema com a máquina?

Certas posições diante da questão da técnica estão bem delineadas desde praticamente as primeiras horas de seu nascimento. Esses autênticos tópoi se formam a partir não apenas do modo como o problema da técnica é intelectualmente elaborado, mas também por uma decisão prévia, e por vezes tácita, acerca de quais dentre as suas múltiplas dimensões receberão a ênfase. É notável a sua tendência de cristalizarem-se como pares de oposição que exercem uma atração polarizadora sobre as discussões mais recentes acerca do tema, constituindo assim uma espécie de subsolo de toda filosofia da técnica.

Para a descrição da posição mais antiga, o trabalho supracitado de Pierre-Maxime Schuhl fornece os principais elementos (1938/1955, pp.60-90). Esse tópos se formou praticamente no e com o nascimento da questão da técnica (quando ainda não havia sido cunhado o termo "filosofia da técnica") e seus maiores porta-vozes foram os escritores ditos utópicos ou românticos, como Owen, Fourier, Michelet, Carlyle e Ruskin. Eles são a principal voz a alertar contra aqueles malefícios mais visíveis e imediatos do maquinismo, geralmente de cunho social e exemplificados na desocupação em massa e nas crises de superprodução. O essencial da posição inaugurada por esses escritores é o pressuposto de que a técnica em si não é nem um bem nem um mal; bons ou maus são os homens que a criam e utilizam, ou ainda as práticas sociais em que o fazer técnico se escora. Por isso, as suas reflexões estão investidas do afã pedagógico e legislador de reformar o homem e a sociedade, dos quais em última instância se originaria o problema da técnica. Também poderíamos chamar essa posição bumanista, uma vez ela faz crer na possibilidade de purgar o desenvolvimento técnico de seus aspectos inumanos e de guiá-lo conforme ideais que pertencem à essência humana, como os de bem e de justiça.

O antípoda do humanismo consolidou-se pouco mais tarde por força dos acontecimentos extremos da Primeira Guerra Mundial e da Crise de 1929. Seu representante emblemático é Oswald Spengler, mas pode-se dizer que já Karl Marx e Ernst Kapp (quem cunhou o termo "filosofia da técnica") incorrem em tal posicionamento. É possível também identificar certas afinidades de Heidegger com tal perspectiva. Seu pressuposto básico é o de que a técnica, sobretudo na forma moderna do maquinismo, desenvolve-se num processo impessoal que escapa 
à alçada deliberativa e decisória dos homens, ganhando por isso o caráter de um destino. Dada a autonomia do acontecer técnico, a atitude sensata diante deste seria buscar apreender a dinâmica intrínseca de seu curso, prevenindo contra o esforço baldado e enganador de guia-lo segundo as melhores intenções humanísticas. Esse tópos é comumente chamado fatalista ${ }^{2}$.

Humanismo e fatalismo nem sempre equivalem, respectivamente, a otimismo e pessimismo, termos também amiúde utilizados para designar posições assumidas diante da técnica. Se entendermos otimismo como a convicção íntima de que o curso vindouro de acontecimentos será o melhor possível para nós e pessimismo como a convicção contrária, então nem todo humanismo é otimista e nem todo fatalismo é pessimista. O humanista, que se esforça por disciplinar o uso da técnica, não possui necessariamente a certeza de que seus esforços pedagógicos ou políticos levarão ao bom fim desejado. O fatalista, convencido por sua vez da existência de uma dinâmica própria da técnica, pode perfeitamente acreditar, como Marx e Kapp, que contrariamente à catástrofe total o desenvolvimento técnico conduzirá "fatalmente" à redenção social ou ao aperfeiçoamento da humanidade.

Mas há uma possibilidade de compreender otimismo e do pessimismo que os torna correspondentes, respectivamente, do humanismo e do fatalismo. Pois em sentido básico, o otimismo constitui-se pela convicção de que por mais duro e desanimador o diagnóstico da situação atual pode-se fazer alguma coisa para transformá-lo, isto é, o otimista acredita que ações individuais ou coletivas têm o poder de influenciar o curso dos acontecimentos históricos. Em contrapartida, o pessimismo fundamental reside em achar que o movimento histórico, em suas linhas essenciais e definitivas, é completamente indiferente ao agir humano.

\section{CONSIDERAÇÕES FINAIS}

\footnotetext{
2 No núcleo do pensamento de Spengler sobre a técnica, cujos registros se encontram no capítulo final de $A$ decadência do Ocidente (1918) e em O homem e a técnica (1931), está a ideia de que a vontade de dominar a natureza está a tal ponto entranhada na alma ocidental que a consciência temerosa dos potenciais efeitos devastadores do maquinismo de nada adiantaria para frear a expansão deste e impedir a consumação do destino trágico dessa cultura. Marx e Kapp também enxergam uma necessidade intrínseca no desenvolvimento da técnica, ainda que sob a perspectiva positiva de um melhoramento da humanidade. O primeiro reconhece no maquinismo, cuja expansão é descrita no Capital como um processo em cadeia (1867/1968, cf. O desenvolvimento da maquinaria, pp.391-407), um momento de aguçamento do antagonismo social e um fator de superação da contradição interior ao capitalismo na marcha inexorável rumo ao apaziguamento definitivo da sociedade. O segundo enxerga no advento das máquinas um ponto alto do caminho evolutivo pelo qual o homem, conhecendo-se progressivamente por analogia com os seus próprios artefatos, atinge a autoconsciência (1877). Heidegger, por sua vez, recupera a ideia de destino em sua interpretação da atual época da técnica, encarando-o como um modo predominante de compreensão basal dos entes, um modo de "desencobrimento" sobre o qual os homens não decidem (1954/1962, p.24ff). De resto, Heidegger pensa que a tendência dominante entre os homens de se representarem como mestres da técnica é na verdade um sintoma de que ela ameaça lhes escapar do controle (1954/1962, p.6f).
} 
É do tipo mais básico de otimismo que precisa em boa dose a reflexão sobre a técnica, sobretudo nesses tempos em que esta exibe um poder inédito na figura da biotecnologia e da informática. Pois aceitar - como no passado o fizeram alguns dos primeiros que depararam com o maquinismo - que a técnica é um ser independente de nós, portador de sua própria dinâmica, significa tirar de si e de seus congêneres o fardo da responsabilidade perante as desgraças que dela possam advir; significa, portanto, anular-se como sujeito ético. Do extremo oposto a essa tendência algo perversa de lavar as mãos espreita por sua vez o perigo de os humanistas mais propensos à ação exagerarem na dose de otimismo ao ponto de inebriarem-se com a própria capacidade realizadora e com os seus ideais-mestres, precipitando-se num voluntarismo engajado que já não pode mais assumir o distanciamento requerido para um questionamento sério da técnica.

Em O princípio responsabilidade assume Hans Jonas o posicionamento humanista com aquela carga de otimismo indispensável às reflexões minimamente sadias sobre a técnica. A tentativa de encontrar uma ética para a civilização tecnológica seria completamente descabida, se partisse da convicção fatalista de que a técnica, e com ela a história, segue um caminho inapelável aos esforços do homem. Tal tentativa, pois, não pode senão radicar no pressuposto de que o futuro depende de alguma forma de decisões e ações feitas no âmbito da liberdade humana. Isso não leva porém ao exagero otimista que desconhece os limites do agir humano diante de grandes movimentos ou processos históricos. Jonas parece assimilar também parte dos ensinamentos emanados do fatalismo, ao reconhecer que a técnica moderna adquire uma ordem de grandeza de tal modo inédita, envolvendo uma longa cadeia de efeitos cumulativos e a impessoalidade de agentes e ações, que se projeta para fora do campo de visão e da esfera de ação dos indivíduos (1979/1984, pp.14-30). Talvez caiba a um estudo mais detido mostrar em que medida a busca de Jonas por uma ética, ainda que não mais circunscrita ao estreito raio de ação individual, seria também uma resposta às colocações fatalistas sobre a dinâmica impessoal e coercitiva da técnica moderna. Teríamos aqui mais um momento no debate iniciado há mais de dois séculos com a expansão das máquinas. 


\section{Referências bibliográficas}

ARISTOTELES. Metaphysik. Neubearbeitung der Übersetzung von H.Bonitz, Mit Einleitung und Kommentar herausgegeben Von H.Seidl, Griechisch-Deutsch, Felix Meiner, Hamburg, 1989 (Bücher I - VI), 429p.

ARISTÓTELES (1998). Nikomachische Ethik VI (H. G. Gadamer, org. e trad., edição bilíngue). Frankfurt am Main: Klostermann, 70p.

HEIDEGGER, M. (1954/1962). Die Frage nach der Technik. Em Die Technik und die Kebre (pp.536). Stuttgart: Klett-Kotta, 47p.

JONAS, H. (1979/1984). Das Prinqip Verantwortung: Versuch einer Ethik für die technologische Zivilisation. Frankfurt am Mainz: Suhrkamp Taschenbuch, 426p.

KAPP, E. (1877/1978). Grundlinien einer Philosopbie der Technik: Zur

Entstehungsgeschichte der Kultur aus neuen Gesichtspunkten. Düsseldorf: Stern-Verlag Janssen \& Co, $360 \mathrm{p}$.

MARX, K. (1867/1968). Das Kapital - Erster Band, Buch I. Em Karl Marx-Friedrich Engels Werke (Bd. 23). Berlin: Dietz, 955p.

ORTEGA Y GASSET, J. (1930/2016). A Rebelião das Massas (introdução Julian Marías, trad. F. Denardi). São Paulo: Vide Editorial, 362p.

PLATÃO (2011). Íon (C. Oliveira, trad.). Belo Horizonte: Autêntica, 88p.

PLATÃO (1972a). Górgias. Em G. Eigler (org.) Werke in acht Bänden:Griechisch und Deutsch (F. Schleiermacher, trad., vol.2, pp.269-504). Darmstadt: Wissenschaftliche Buchgesellschaft, 606p.

PLATÃO (1972b). Philebos. Em G. Eigler (org.) Werke in acht Bänden:Griechisch und Deutsch (F. Schleiermacher, trad., vol.7, pp.255-443). Darmstadt: Wissenschaftliche Buchgesellschaft, 449p. 
SCHUHL, P-M (1938/1955). Maquinismo y filosofia (trad. H. Crespo). Buenos Aires: Galatea/Nueva Visión, 123p.

SPENGLER, O. (1918/1963). Der Untergang des Abendlandes: Umrisse einer Morphologie der Weltgeschichte (vollständige Aufgabe in einem Band). München: C.H. Beck, 1249p.

SPENGLER, O. (1931). Der Mensch und die Technik. München: C.H. Beck, 89p. 


\title{
PRINCÍPIO RESPONSABILIDADE E POLÍTICA DO DECRESCIMENTO: APROXIMAÇÕES E CONVERGÊNCIAS
}

\author{
The imperative of responsibility and the politics of decreasing: \\ Approaches and convergences
}

\author{
Mario Sergio Cunha Alencastro \\ Centro Universitário Internacional UNINTER \\ Mestrado em Educação e Novas Tecnologias \\ Eleandro de Souza Cabral \\ Centro Universitário Internacional UNINTER \\ Mestrado em Educação e Novas Tecnologias
}

RESUMO: A presente pesquisa tem como objetivo compreender abordagem temática sobre a "ética da responsabilidade" proposta pelo filósofo alemão Hans Jonas em sua mais influente obra: O Princípio Responsabilidade: Ensaio de uma ética para a civilização tecnológica, apresentando uma discussão acerca de como seus fundamentos ético-filosóficos se encontra em sintonia com a proposta política de decrescimento, assim como, em contrapartida demonstrar apontamentos pelos quais o autor se afasta das concepções do atual modelo de desenvolvimento sustentável. Esta pesquisa possui caráter bibliográfico, e efetiva uma análise acareando um posicionamento consequencialista frente ao descompasso entre a factual imprevisibilidade dos atos praticados pela humanidade e a degradação do meio ambiente promovida pela "Era da Civilização Tecnológica". Intenciona refletir sobre o posicionamento humano em relação à natureza ressaltando seu antropocentrismo exacerbado, perpassando a proposta de decrescimento como possibilidade de mediação responsável que atenda cuidados para com as gerações futuras e a vida planetária.

Palavras-chave: Hans Jonas; Responsabilidade; Decrescimento;

\section{INTRODUÇÃO}

A presente investigação emerge em um cenário global impactado pelo desequilíbrio ético da existência humana em relação aos seus pares enquanto partícipe de uma biosfera una, e é constituída em face da relevância apontada ao tema meio ambiente. Este mesmo ambiente sofre atualmente diversas alterações provenientes das ações imputadas pelo ser humano em seu habitat, o que denota um efeito rebote nocivo em face da vulnerabilidade deste ser e principalmente da natureza extra-humana. 
A capacidade humana de controlar e moldar o meio ambiente atribui ao contexto atual paradoxo insolúvel, no qual, na medida em que cresce a capacidade da técnica, maior se torna a deteriorização do nosso ambiente, e seus efeitos são agora atribuídos não somente a determinadas regiões ou populações, mas sim, se propagam e atingem a esfera global.

A delimitação do tema deste estudo decorre dos efeitos nocivos da Revolução Industrial e do empoderamento humano por meio da tecnologia, os quais denotam ao século XXI um legado que ameaça toda a sociedade contemporânea por meio da devastação ambiental.

Desta forma oportunizaremos neste estudo conhecer sobre a proposta Política de Decrescimento e seus principais pressupostos, tendo em vista a utilização descontrolada dos recursos não renováveis de nosso planeta. Pretende-se analisar o alinhamento da proposta Política do Decrescimento com os pressupostos da ética jonasiana, investigando como a articulação dessas duas teorias se relacionam e convergem para a ruptura com o antropocentrismo e a possibilidade de redução da produção e consumo ilimitado. Sabendo que estes dois fatores se apresentam como principal fator gerador da crise ambiental vivida pela civilização contemporânea, buscaremos possibilitar resposta à seguinte problemática: de que modo a fundamentação ético-filosóficos de Hans Jonas se encontram em maior sintonia com a proposta política de decrescimento e se afasta das concepções do atual modelo de desenvolvimento sustentável?

Fecharemos a circularidade do método argumentando sobre a sintonia existente entre a política do decrescimento e a ética da responsabilidade demonstrando que ambas alinhadas possuem fundamentação possível de auxiliar a civilização humana contemporânea construir condições de enfrentamento ao poder que hoje degrada nosso meio ambiente.

A hipótese apresentada, busca estruturar uma análise ontológica e ética que permita diálogo entre as respectivas teorias propondo um poder sobre o poder que faça frente aos anseios e desafios que esta nova sociedade experimenta.

\section{ONTOLOGIA SOBRE O DECRESCIMENTO}

O questionamento fundamental neste momento crítico não é mais apenas o ser humano, mas sim a vida como um sistema complexo interligado, onde a causa e efeito se tornam uma coisa somente. Jonas afirma que:

O futuro da humanidade é o primeiro dever do comportamento coletivo humano na idade da civilização técnica, que se tornou toda poderosa no que tange ao seu 
potencial de destruição. Esse futuro da humanidade inclui, obviamente, o futuro da natureza como sua condição "sine qua non"1 (JONAS, 2006, p.229).

O imperativo Jonasiano neste caso busca garantir a preservação das condições futuras para que a vida humana e extra-humana continue com sua autenticidade, referenciando a reciprocidade que deve haver entre elas. A grande provocação de Jonas está no dever, dever este nato em função do perigo, onde seu primeiro balbuciar está clamando por uma ética de preservação, e não por uma ética de progresso ou aperfeiçoamento (2006, p.232).

Quando a Política do Decrescimento trata solidariamente sobre o progresso, atribui à conotação de ateísmo econômico como uma forma de suspender a crença de que o crescimento é a alternativa e propósito último das sociedades. Faz-se necessário estar liberto da concepção de desenvolvimento e crescimento, entretanto, isto não implicam em renúncia as instituições sociais econômicas, mas sim, inseri-las em outra lógica que não seja a de produzir mais e consumir mais (LATOUCHE, 2010, p.19).

Este mundo, como montado, não se sustenta e o efeito rebote é o argumento central para o decrescimento, ou seja, a redução dos impactos ambientais não pode ser produzida sem uma diminuição do desenvolvimento econômico. Necessário se faz a redução da exploração dos recursos do planeta, pois como primeiro impacto terá a escassez da matéria prima, seguida pela inflação nos valores dos produtos, que por consequência reduzirá significativamente o poder de compra, gerando assim enorme estagnação econômica (BECK, 2010, p.241). O ponto crucial está em estabelecer ações verdadeiramente eficientes e preventivas, realocando o consumo para rumos que nos tragam benefícios ambientais.

\section{DECRESCIMENTO}

Decrescimento é uma linha de pensamento econômico e também político que teve sua origem na década de 1970, alicerçado nas teses do economista romeno, precursor da bioeconomia, Nicholas Georgescu-Roegen, as quais foram publicadas em sua obra The Entropy Law and the Economic Process (1971).

A teoria do decrescimento esta baseada na hipótese de que o crescimento econômico entendido também como aumento constante do Produto Interno Bruto (PIB) não é sustentável para o ecossistema global. Essa ideia é oposta ao pensamento econômico dominante, segundo o qual a melhoria do nível de vida seria decorrência do crescimento do PIB, e, assim, o aumento do valor da produção deveria ser um objetivo permanente da sociedade (LATOUCHE, 2006, p.19).

\footnotetext{
${ }^{1}$ Sine qua non ou conditio sine qua non é uma expressão que originou-se do termo legal em latim que pode ser traduzido como "sem a/o qual não pode ser". Refere-se a uma ação cuja condição ou ingrediente é indispensável e essencial.
} 
Para Serge Latouche a principal questão é a que os recursos naturais são limitados, e, portanto, não existe crescimento infinito. A melhoria das condições de vida deve, portanto, ser obtida sem aumento do consumo, mudando-se o paradigma dominante. O conceito de decrescimento não está pontuado em contrariedade ao consumo, já que seus fundamentos são propostos a partir do produtivismo, entretanto, afirma que não há nenhuma possibilidade de crescimento infinito num planeta finito (LATOUCHE, 2006, p.33). Serge Latouche opõe-se, portanto, ao consenso generalizado de que o crescimento econômico é o fundamento primeiro do bem-estar humano. Além disso, o aumento constante do PIB mundial por mais 50 anos, afetará a pegada ecológica da humanidade, que segundo ele, o impacto das nossas sociedades no ambiente já ultrapassa em quase 30\% a capacidade regenerativa do planeta.

Latouche (2006, p.36) quando aborda sobre o decrescimento afirma não se tratar de um estado estacionário como propostos em velhos clássicos, tão pouco uma forma de regressão, recessão ou crescimento negativo. Denota sim, que com todo rigor que deve ser entendido e chamado de acrescimento, fazendo menção ao ateísmo, pois em analogia contrária demonstra a fé e crença no PIB, em crescimento infinito, e na condição de solucionar problemas sociais apenas pelo viés econômico.

Sob o prisma proposto pela Política do Decrescimento, para que aconteça a conversão ecológica da economia, devemos reduzir o consumo e produção de acordo com as nossas necessidades reais, liberando tempo para investir em atividades criativas de riqueza social e ecológica. Em suma, devemos optar por cidadania, educação, justiça social e ambiental, em outras palavras, vamos apostar em viver melhor com menos. Latouche apregoa que se deve buscar o mesmo nível de satisfação sem a necessidade de recorrer ao sistema mercantilista, em suas próprias palavras: "El impacto es un retroceso del PIB y en consecuencia de la huella ecologica para mayor felicidad de todos (salvo tal vez para los comerciantes...)", (LATOUCHE, 2006, p.101).

Em continuidade afirma que não se deve entender o decrescimento como uma alternativa única e substituidora do modelo atual, mas um aviso sobre os riscos da situação em que vivemos, um grito por mudança. $\mathrm{O}$ decrescimento estaria para a humanidade como uma proteção mínima que possibilitaria iniciar a desconstrução do imaginário comum de que para avançar é necessário consumir.

Entende Latouche (2006, p.49) que o valor principal deva estar nas relações sociais e numa harmoniosa convivência de todos com a parte ecológica. Para tanto, faz-se necessário uma profunda mudança de valores.

\section{PRESSUPOSTOS DA TEORIA DO DECRESCIMENTO}


Além das considerações extraídas da experiência com o consumismo, Latouche traça determinadas linhas que devemos chamar de o fim econômico, pelo menos na acepção clássica do termo. A proposta do decrescimento aposta em uma economia desmaterializada, menos recursos naturais, bem mais uma economia de mobilização e conhecimentos especializados e bem menos de manipulação e transformação das matérias ponderáveis, o homem se tornará o centro desta proposta, entretanto, um centro como produção de valor (LATOUCHE, 2009, p. 115).

Latouche acredita que o PIB é uma medida apenas parcial da riqueza e que, se pretendemos restabelecer toda a variedade de riquezas possíveis, é preciso deixar de utilizá-lo como bússola. Assim, defende a utilização de outros indicadores, tais como o IDH, a Pegada

Ecológica e o Índice de Saúde Social, defende também, a revisão de conceitos como o desenvolvimento, o trabalho ou a riqueza, e o aprofundamento e resgate da justiça social, cidadania e democracia.

Ulrich Beck (2007, p.43) também teórico do decrescimento, descreve que o caracol constrói a sua concha somando, uma a uma, espirais cada vez maiores. E em determinado momento detém-se abruptamente e começa a fazer voltas decrescentes. Uma espiral a mais somente faria com que a concha fosse dezesseis vezes maior, sobrecarregando o animal. A partir daí, qualquer aumento da sua produtividade serviria somente para aliviar as dificuldades criadas por uma concha que crescera demais. Nesse limite, o problema do hiper-crescimento multiplicase em progressão geométrica, enquanto a capacidade biológica do caracol somente pode, no melhor dos casos, seguir uma progressão aritmética.

\section{CONSIDERAÇÕES FINAIS}

Em face ao cenário desafiador apresentado à contemporaneidade humana, este conferido pela crise ambiental instalada e pelo vazio ético encontrado nas mais diversas sociedades do planeta, é proposta uma ruptura com as propostas éticas tradicionais, a qual acontece em oportunidade da publicação de O Princípio Responsabilidade. O sistema ético encontrado até então, não trata da perspectiva dos seres humanos e não-humanos, mas sim, apenas de proposições voltadas ao relacionamento do indivíduo para com seus pares, a abertura desta nova proposta referencia Hans Jonas como marco fundamental na filosofia.

O núcleo da filosofia de Jonas se constitui em um necessário enfrentamento ao avanço tecnológico promovido pelas descobertas científicas e pelo avanço tecnológico humano, o qual detinha o controle sobre estas variáveis e a utilizava como meio para sua sobrevivência e comodidade. Em tempos atuais, e pela desenfreada busca por conhecimento, a humanidade sofre uma inversão entre os papéis que norteiam esta relação, a qual sai de detentora e controladora 
deste conhecimento, para objeto de manipulação e controlado. Jonas ao se defrontar com tal disparate propõe com extrema primazia uma ética que possibilite a não destruição humana, a preservação da natureza extra-humana e da manutenção das futuras gerações, entendendo não ser mais possível a regulação das ações do homem sob um prisma ético tradicional. Agrega a sua tese a necessidade de impreterivelmente não sujeitar a uma sorte temerária a biosfera planetária

Neste aspecto, a proposta da Política de Decrescimento de Serge Latouche ao se aliar a proposta do pensador alemão coadunará em fortalecer um pensamento ético de preservação planetária, a qual promoverá conscientização para cuidados com a biosfera de monta global.

Em resultado, o conjunto de partes coordenadas pelo consumismo insiste em não observar os assustadores sinais já emitidos pelo meio ambiente. O furor da técnica apresentada nesta pesquisa por meio de seu tentáculo mais subliminar, o consumo exacerbado, fomenta através de mecanismos e estratégias a sequência viciosa que manipula o indivíduo a sempre buscar a felicidade e o bem-estar na aquisição de bens. Entretanto, e como já vimos anteriormente, manifestadamente se consome recursos naturais não renováveis para esta produção

Sob o prisma da Política do Decrescimento tal problemática também é diagnosticada com formulação que transita sobre os mesmos trilhos de Hans Jonas, principalmente quando Serge Latouche aponta que a sociedade moderna utilize para uso próprio aproximadamente $30 \%$ a mais do que a biosfera é capaz de se regenerar, chegando ao ponto de sugerir inclusive a possibilidade de um o controle massivo da população ou a redução do consumo (LATOUCHE, 2009, p. 31).

A luz das afirmações de Jonas e Latouche, ambas apresentam convergências, visto a necessidade prática das teorias, Jonas define qual é objeto a ser defendido e quais os valores morais e éticos a serem utilizados e Latouche se manifesta apresentando como e onde atualmente o freio voluntário proposto pelo Princípio Responsabilidade encontrará resultado mais efetivo.

A proposta jonasiana trabalha a questão político ambiental trazendo inferências sobre o idealismo socialista e a democracia capitalista, mas de forma cautelosa não atribuí única e exclusivamente juízo de valor em ambos os sistemas (JONAS, 2006, p.241).

Mas ainda na esfera política Jonas invoca a responsabilidade política no papel do homem público, neste caso definido por ele como político e não pelo cargo técnico do funcionário, no qual menciona a potencialidade da missão deste homem quando identifica que fez o melhor que pode por aqueles sobre os quais detinha poder (JONAS, 2006, p.172).

$\mathrm{Na}$ visão de Serge Latouche a política fica incumbida de tratar de ações públicas que visem ao bem-estar das sociedades, primando pela construção de atitudes individuais formatadas em rede pensadas a partir de uma articulação aberta de movimento. Apresenta o capitalismo 
neoliberal elitista, assim como o socialismo partidário de massa, como precondições de continuidade para o avanço do consumo.

Através das perspectivas políticas apresentadas não encontramos isenção sobre o assunto, ambos pensadores se ocupam em desenvolver suas teorias propondo um determinado ceticismo perante aos sistemas de governo. Aperfeiçoam a questão da responsabilidade como um fenômeno integral de confluência entre seres humanos e meio ambientes.

Já na idéia de progresso o que movem as sociedades são os sonhos e as utopias projetadas por elas mesmas e seus esforços em transformá-las em realidade (BOFF, 2015, p.70). Neste aspecto o posicionamento de Hans Jonas e Serge Latouche estão alinhados perfeitamente por entenderem que não será possível a continuidade de crescimento mundial apenas pautado pelo bem-estar através do consumismo. Jonas se coloca da seguinte forma: "In Summa: em vez do crescimento, a palavra de ordem será a contração, algo muito mais difícil para os pregadores da utopia do que para os pragmáticos, desvinculados de ideologias”. (JONAS, 2006, p.265). Seguindo esta mesma linha de pensamento Latouche acredita que a riqueza produzida pelos sistemas econômicos não consiste apenas de bens e serviços, existem outras formas de riqueza social, tais como a educação, expectativa de vida, saneamento básico, moradia, transporte, saúde dos ecossistemas, a qualidade da justiça e das relações entre os membros de uma sociedade, o grau de igualdade e o caráter democrático das instituições. O crescimento da riqueza material, medido apenas por indicadores monetários, pode ocorrer em detrimento dessas outras formas de riqueza. Acredita que o PIB é uma medida apenas parcial da riqueza, e que, se pretendemos restabelecer toda a variedade de riquezas possíveis, é preciso deixar sua ideologia como bússola. Assim, defende a utilização de outros indicadores, tais como o IDH, a Pegada Ecológica e o Índice de Saúde Social (LATOUCHE, 2009, p. 139).

Ao tratarmos de uma suposição admissível futura de um desastre ambiental de proporções globais, abrimos caminho para análise da heurística do medo, nomeada por Jonas de futurologia comparativa (2006, p.70). Podemos compreender a terminologia mais defendida, Heurística do Temor, de forma ontológica, como sendo temor o sentimento que traz temor de algo ou alguém, e heurística como sendo a possibilidade de previsão ou temer determinada possibilidade (SÈVE, 1992, p.108, apud OLIVEIRA, 2014, p.133). Essa possibilidade buscará formar um arcabouço de saberes práticos em tempo presente sobre ações danosas e traçados perigosos que se encontram na esfera hipotética. Nesta abordagem Jonas busca formatar prognósticos partindo de pressupostos teóricos que transpasse e produza uma compassibilidade temerária que arregimente um medo ou temor (apesar de Jonas não distinguir didaticamente a 
diferença entre estes dois termos) que seja possível de desassimilação de um desejado resultado breve favorecendo determinado resultado de longo prazo (2006, p.74).

Em detrimento as éticas tradicionais, as quais laboram sobre pressupostos já experimentados, a ética da responsabilidade transita no âmbito exploratório de novas necessidades emergentes. Quando transpomos o foco de tal teoria para a análise do contexto ambiental marcado pelo consumismo antropocêntrico, nos deparamos com a complexidade da evolução humana e a imprevisibilidade que voeja sobre suas atitudes. Diante desta, Jonas aponta para uma proposta que busque identificar com antecedência a possibilidade de antever eventual deformação do homem, quando este aposta em ações sem a prévia análise futura das consequências, conforme suas próprias palavras: "só sabemos o que está em jogo quando sabemos que isto ou aquilo está em jogo" (2006, p.71). Jonas também ambiciona no sentido de que a incerteza dos prognósticos de longo prazo não possui possibilidade estática de ser dimensionada através de princípios da esfera dos fatos, os quais consideravam apenas aquilo que nos é próximo, deixando que o futuro cuidasse de si mesmo (2006, p.83). Ao concernir o progresso tecnológico e o consumismo humano crescente, o tratamento da incerteza nos obriga incondicionalmente em assumirmos a responsabilidade pelo que se apresentará como resultado de nossas ações, sendo então necessário através da heurística do temor tratar como certo o que se apresenta como duvidoso, primando sempre à possibilidade que previsionará o prognóstico com maior valor negativo, evitando assim arriscar interesses futuros se baseando fatos e riscos presentes, estaria tal ação comparada a construir um edifício sem escadas, visando futuramente suplantar a teoria da gravidade (2006, p.85).

Conforme posto anteriormente no corpo desta pesquisa, a política do decrescimento não está inerte a conjuctura dos riscos futuros e sua imprevisibilidade. Latouche afirma que mesmo que as eminentes catástrofes não abarcassem a destruição prevista, em seu prognóstico mais negativo, estas seriam promotoras de uma educação significativa em um conceito pedagógico, e trariam a pauta ensinamentos que relatariam os fatores de risco e os perigos do delírio produtivista (LATOUCHE, 2009, p. 95). Afirma ainda que ao mesmo tempo em que a debilitação do meio ambiente nos traz padecimento, também oportuniza as condições de conscientização. Nesta proposição Latouche entende a Heurística do Temor de Jonas como a necessidade de inserir no conjunto humano conteste os perigos ambientais eminentes, evitando assim um otimismo suicida da técnica e consumo. Latouche cita o filósofo francês Jean-Pierre Dupuy, que em sua a obra O Tempo das Catástrofes - quando o impossível é uma certeza (2011) afirma: "o que pode nos salvar é justamente o que nos ameaça". 
Na visão de Edgard Morin (2011, p.61) o qual se exprime de forma concludente com a formulação herança de morte para se direcionar a alusão da herança ofertada pelo século XX às sociedades contemporâneas, sabendo que este, trata sobre o aumento progressivo do poderio destruidor da técnica e consumo na transformação humana, que sobre uma perspectiva simplista pode nos levar sem a menor dúvida a uma morte ecológica.

Assim, a pesquisa em voga, por meio da sistematização dos assuntos elencados, busca desenvolver a possibilidade de reflexão junto à sociedade humana deste novo milênio, robustecendo cada indivíduo a tratar a problemática da técnica e consumo através de uma conotação ética que os liberte do ciclo vicioso ora instalado.

Insuflado por suas recorrentes descobertas seja perante o prolongamento da vida, o controle do comportamento humano ou a manipulação genética, o resgate do homo faber à sua condição de natureza se fará iniciado pela observância do próprio poder que o aprisiona. Neste caso o comportamento humano atribui força na movimentação da techné. Este comportamento por ser progenitor do circuito em que se autoderiva o indivíduo, deve ser trabalhado de forma se encontrar uma fenda na armadura onde se possibilitará libertar o objeto homo faber à reflexão, gerando assim a possibilidade de se frear o movimento doutrinador. Nas palavras de Hans Jonas (2006, p.91): "Pode-se dizer que os perigos que ameaçam o futuro modo de ser são, em geral, os mesmos que, em maior escala, ameaçam a existência; por isso, evitar os primeiros significa a fortiori evitar os outros".

Caberá então a filosofia oferecer ao ser humano orientação para o futuro, não mais travando uma inútil luta com os galhos, mas sabendo sim, que é no troco onde se encontra a tessitura do conjunto, no qual sua abertura através do conhecimento possibilitar-se-á a este refletir sobre sua condição moral frente às mudanças da natureza e sua preservação.

Mesmo uma sociedade inteira, uma nação, enfim, todas as sociedades contemporâneas tomadas em conjunto, não são proprietárias da terra. Elas são apenas ocupantes, usufrutuárias (Nutzniesser), e devem, como bons paters famílias, deixá-las em melhor estado para as futuras gerações (MARX, 1985, p.154).

Ao analisarmos o contexto sócio ambiental contemporâneo encontramos razões suficientes para revermos de forma contundente o atual modelo de desenvolvimento sustentável, o atual modelo de progresso e principalmente a cultura moral e ética hoje inseminada na humanidade. Latouche através da política do decrescimento, e esta, através de seu slogan provocador, que ao se justapor aos ateus da religião do crescimento, aos agnósticos do progresso, e principalmente orientada pelo princípio responsabilidade de Jonas, poderão aferir a possibilidade de enfrentamento da técnica transformadora. 


\section{REFERÊNCIAS}

ALENCASTRO, M.S.C. Ética e meio ambiente: construindo as bases para um futuro sustentável. Curitiba: InterSaberes, 2015.

BECK, U. GIDDENS, A. LASH, S. Modernização reflexiva: política, tradição e estética na ordem social moderna. São Paulo: Editora da Universidade Estadual Paulista, 1997.

BECK, U. Sociedade de risco: rumo a uma outra modernidade. Tradução de Sebastião Nascimento. São Paulo: Ed. 34; 2010.

BOFF, L. Sustentabilidade: o que é: o que não é. Rio de Janeiro: Vozes, 2012.

COMISSÃO DA CARTA DA TERRA. Carta da Terra. 2000. Disponível em: <http://www.earthcharter.org/files/charter/charter_po.pdf. Acesso em maio/2016.

EVANGELISTA, W. A renovação da teleologia em Hans Jonas: da biologia filosófica aos fundamentos da ética. Revista Princípios (UFRN), v.17, n.28, 2010.

HECK, J.N. O princípio responsabilidade e a teleologia objetiva dos valores. IN: SANTOS, Robinson dos (Org). Ética para a civilização tecnológica: Em diálogo com Hans Jonas. São Paulo: Ed. São Camilo, 2011.

JONAS, H. O princípio responsabilidade : ensaio de uma ética para a civilização tecnológica. Rio de Janeiro: PUC- Rio, 2006.

Vozes, 2004.

O princípio vida: Fundamentos para uma biologia filosófica. Petrópolis (RJ):

LATOUCHE, S. La apuesta por el decrecimiento. Cómo salir Del imaginario dominante? Barcelona: Icaria Editorial, 2006.

LATOUCHE, S. Farewell to Growth. Translated by David Macey. Cambridge: Polity Press, 2009.

LEFF, E. Saber ambiental: sustentabilidade, racionalidade, complexidade e poder. 2. ed. Petrópolis: Vozes, 2001.

MORIN, Edgard. Os sete saberes necessários à educação do futuro. 2. ed. São Paulo: Cortez; Brasília: UNESCO, 2011.

OLIVEIRA, J. Compreender Hans Jonas. Petrópolis: Vozes, 2014. - (Série compreender)

OLIVEIRA, J. SGANZERLA, A. e MORETTO, G. Vida, técnica e responsabilidade: três ensaios sobre a filosofia de Hans Jonas. São Paulo: Paulus, 2015. - (Coleção Ethos) 
ONU - ORGANIZAÇÕES DAS NAÇÕES UNIDAS. Objetivos do Milênio. 2000. Disponível em: <http://www.nospodemos.org.br/>. Acesso em: fevereiro/2016.

SGANZERLA, A. Natureza e responsabilidade : Hans Jonas e a biologização do ser moral. São Carlos: UFSC, 2012. 214 f. Tese 270 f. - Programa de Pós-Graduação em Filosofia, Universidade Federal de São Carlos Federal do Rio Grande do Sul, Porto Alegre, 1983, (Doutorado em Filosofia).

WORLDWATCH INSTITUTE - WWI. Estado do Mundo, 2010 - Transformando culturas: estadodo consumo e o consumo sustentável. Salvador: Uma Ed., 2010. Disponível em: <http://www.uma.org.br/estado_2015.pdf >. Acesso em: 11 mar. 2016. 


\title{
SER COMO FIM IMANENTE: A ÉTICA DA RESPONSABILIDADE DE HANS JONAS
}

Being as an immanent end: Hans Jonas' ethic of responsibility

Gabriel Prado Rodrigues

Graduando em Filosofia/UFRJ

\begin{abstract}
RESUMO: Minha pesquisa tem como foco a elucidação dos pontos principais do sistema teórico elaborado pelo filósofo alemão Hans Jonas, em especial no que tange à sua ética. Para Jonas, o advento da técnica moderna modificou em grande medida a forma como os seres humanos interagem com a natureza e consigo mesmos. A humanidade não apenas dispõe de novos meios para realizar ações sobre o planeta como lhe foge, por vezes, o controle e a capacidade para prever os resultados de seus empreendimentos. Estes e outros aspectos de nossa civilização tecnocientífica suscitam problemas cujas soluções não foram pensadas por éticas tradicionais o que, para Jonas, indica a necessidade do desenvolvimento um novo sistema ético centrado no princípio responsabilidade, de fundamento ontológico, para dar conta do risco que correm seres humanos e não humanos em virtude das novas dimensões espaçotemporais das ações do homem. Nesse sentido, a ética jonasiana é também uma ética do futuro, uma vez que busca englobar ainda ações da técnica moderna cujas consequências negativas talvez levem muito tempo para aparecer. Tendo como principal fonte de pesquisa o livro Princípio Responsabilidade, de Jonas, procurei apontar e esclarecer conceitos elementares de seu pensamento, além de brevemente traçar seu lugar em relação a algumas tendências filosóficas também questionadoras do papel da ciência e da tecnologia modernas na sociedade.
\end{abstract}

PALAVRAS-CHAVE: Hans Jonas; ética; responsabilidade.

ABSTRACT: My research focuses on the elucidation of the main points of the theoretical system elaborated by the German philosopher Hans Jonas, especially with regard to his ethics. For Jonas, the advent of modern technology has greatly changed the way humans interact with nature and with themselves. Humanity not only has new means to carry out actions on the planet but sometimes it lacks the control and the ability to predict the results of its ventures. These and other aspects of our technoscientific civilization give rise to problems whose solutions were not proposed by traditional ethics. Jonas sought to develop a new ethical system centered on the ontological principle of responsibility to account for the risk that human and non-human beings have in virtue of the new spatio-temporal dimensions of human actions. In this sense, Jonasian 
ethics is also aimed at the future, since it seeks to include actions of modern technique whose negative consequences may take a long time to appear. Having as main research source the book The Imperative of Responsibility, I tried to point out and clarify elementary concepts of his thought, as well as to briefly trace his place in relation to some philosophical tendencies that also question the role of modern science and technology in society.

KEYWORDS: Hans Jonas; ethics; responsibility.

\section{INTRODUÇÃO}

Hans Jonas (1903-1993) propõe o resgate de finalidades naturais imanentes como base para a fundamentação do dever do homem em relação ao mundo e seus habitantes. Em $O$ Princípio Responsabilidade, Jonas trava debate com inclinação teórica cientificista de alguns saberes de sua época, marcada pela influência do positivismo comteano disseminado ao longo do século XIX (DARTIGUES, 1992). De acordo com o positivismo, explicações científicas objetivas sobre a realidade são os paradigmas de todo conhecimento válido, de modo que "somente são reais os conhecimentos que repousam sobre fatos observados" (COMTE, 1973, p.11).O método das ciências naturais, renovado pela Revolução Científica que deu origem à ciência moderna no século XVII, ameaçaria assim ser estendido a outros campos, comprometendo o estudo de áreas como a Ética, cujos postulados não seriam verificáveis pela simples observação factual ou pela experimentação empírica controlada. Muitos pensadores identificaram as complicações derivadas da noção de ciência proposta pelo positivismo e procuraram criticá-la.

Por exemplo, Max Weber se refere à ciência e à religião ocidentais como instrumentos de um "desencantamento do mundo", isto é, do processo pelo qual fenômenos da realidade passariam a ser explicados de forma gradualmente menos mística e cada vez mais mecânica, desprovida de sentido próprio ${ }^{1}$. Também Edmund Husserl afirma que a pretensão de redução do conhecimento como um todo ao que pode ser produzido pela ciência empírica constitui o 'objetivismo', sob o qual o acesso da ciência ao real seria entendido como puro e totalmente livre de elementos subjetivos. Confunde-se assim a realidade com sua representação matematizada, com uma "veste de ideias" (HUSSERL, 1976, p.60). Cumpre dizer que o objetivo de tais críticas não foi eliminar a ciência como modo de verificação e produção de conhecimento, mas expor suas limitações quando tenta propor modelos totais de descrição do mundo. Isto equivale a

${ }^{1}$ Cf. SHULL, K.K. Is the Magic Gone? Weber's "Disenchantment of the World" and its Implications for Art in Today's World. Anamesa, New York, v.3, i. 2, p.61, fall. 2005. 
afirmar que o método científico é eficaz quando busca o conhecimento de objetos e a enunciação de suas relações através de leis, mas que não consegue abarcar todos os aspectos do real.

$\mathrm{Na}$ esteira desses pensamentos, Hans Jonas busca problematizar um dos principais frutos desta tendência cientificista: a técnica moderna. Para Jonas, a técnica moderna, pela primeira vez na história da humanidade, coloca em risco a existência da espécie humana como um todo assim como da natureza orgânica da qual faz parte. Isso ocorre porque os mecanismos e o dinamismo das criações tecnológicas começam a ultrapassar em grande medida o poder de previsão e de controle do homem sobre suas invenções. Para Jonas, é necessário que a ciência, separada da filosofia a partir da modernidade e compreendida desde então como domínio do empírico e do experimental, também seja pensada à luz da ética. É imperativo questionar a distinção essencial entre dever e ser pressuposta pela ciência, que parece recusar "qualquer direito teórico de pensar a natureza como algo que devamos respeitar - uma vez que ela a reduziu à indiferença da necessidade e do acaso, despindo-a de toda dignidade de fins." (JONAS, 2006, p.43)

Nesse ponto, Jonas coloca uma questão não levantada por filosofias morais tradicionais: o risco da destruição total do mundo e da impossibilidade das gerações futura sem virtude de ações humanas irrefletidas e a indispensabilidade da criação de um novo sistema ético com a finalidade de impedir a aniquilação do Ser. A Ética deve adentrar a esfera antes eticamente neutra da techne, isto é, da relação do ser humano com a "natureza" entendida como tudo que não é humano ou sua criação.

\section{HEIDEGGER E A TÉCNICA MODERNA}

Jonas foi profundamente influenciado pela obra de Martin Heidegger, de quem, não por acaso, foi aluno. A filosofia heideggeriana se funda no que Heidegger denomina "diferença ontológica", isto é, na distinção entre os conceitos de "ser" e de "ente". Para ele, ente "é tudo de que falamos dessa ou daquela maneira, ente é também o que e como nós mesmos somos" (HEIDEGGER, 2006, p.42), é o que designamos quando afirmamos que algo "é". Em suma, qualquer coisa no campo da experiência humana é um ente, um animal, uma planta, um pensamento e até mesmo nós, entes que investigam os entes em geral (ANDRADE, 1982). O ser, por sua vez, é "o que determina o ente como ente, o em vista de que o ente já está sempre sendo compreendido, em qualquer discussão" (Ibidem, p.41). Para Heidegger, o ser é aquilo que é sempre de um ente (Ibidem, p.77), que se desvela e se vela sempre a partir dos entes, mas nunca é, ele próprio, desvelado por completo. Ele se oculta e se mostra segundo modos de ser dos entes em virtude da natureza temporal da compreensão. 
O ponto de partida da concepção heideggeriana é a crítica a toda a história da metafísica ocidental como dimensão do esquecimento do ser desde Platão e Aristóteles até a Lógica de Hegel (Ibidem, p.37). Segundo Heidegger, o ser, a partir da tradição platônica, foi considerado de maneira "essencialista", a metafísica procurou pensar o ser enquanto ser, e não como modo de ser dos entes. O âmbito do "aparecer", no qual os entes se mostram a partir de si mesmos, foi ocultado pelo simples questionamento dos entes e não do ser. A abordagem essencialista tornouse dominante no campo da própria ciência moderna, que encara os entes já significados dentro das regras de seu próprio sistema.

Tal reflexão é relevante para entender o pensamento de Jonas pois Heidegger coloca, como ente privilegiado a partir do qual é possível o questionamento do ser enquanto domínio do aparecer, o que ele chama, em alemão, de Dasein. Dasein é nada mais que o ente humano, aquele capaz de compreender os modos de ser próprios dos entes e de questioná-los. Sua única determinação consiste em ser sempre abertura para modos possíveis de ser. Ele se diferencia dos outros entes, pois é o único que se dá conta de si mesmo no mundo e assim aparece para si, participa do desvelar do ser dos entes. É a partir do ente humano que se tem início o questionamento do sentido do ser. Heidegger parte disso quando diz que uma das possíveis formas de desvelamento é a técnica moderna (HEIDEGGER, 2002, p.18). Ao questionar a essência desse modo de desvelamento do ser, Heidegger conclui que ele explora os entes, desencobre (ou desvela) modos de ser de maneira violenta, exploratória, forçando a natureza a tomar formas que objetivam a satisfação de necessidades humanas. Exemplos disso são jazidas de minérios ou usinas hidrelétricas (Ibidem, p.20), modos que jamais viriam a ser naturalmente, sem a exploração humana. O desvelar do ser dos entes por eles mesmos é substituído pelo simples desvelamento de todos como energia a ser armazenada e subsequentemente consumida pela sociedade. A técnica moderna se concretizaria, assim, como a forma acabada do esquecimento do ser iniciado na metafísica platônica, como domínio da representação e da objetividade científica que se daria a partir do engessamento em um modo de ser técnico.

Jonas, como Heidegger, aponta também que a técnica em suas dimensões modernas instrumentaliza a relação entre o ser humano e a natureza. Pela primazia do modo técnico de desvelamento, segundo o qual tudo é meio e instrumento para algo, a relação do ser humano com a realidade como abertura para possibilidades seria colocada em risco. Nesse sentido, o questionamento da técnica moderna não é, em primeiro lugar, meramente relativo ao campo da prática em oposição ao da teoria:

O processo científico mesmo se desenvolve em inter-relação com o tecnológico, e isto no sentido intimamente mais vital: para alcançar seus próprios objetivos teóricos, a ciência necessita uma tecnologia cada vez mais 
refinada e fisicamente forte como ferramenta que se produz a si mesma, ou seja, que cabe à tecnologia. [...] Desse modo, o aparato é comum ao reino teórico e prático; ou seja, tanto a tecnologia infiltra-se na ciência quanto a ciência na tecnologia. Em resumo: existe entre elas uma mútua relação de feedback que as mantém em movimento; cada uma necessita e impulsiona a outra. (JONAS, 2013, p.30)

Técnica e ciência se tornam imbricadas em relação circular de mútua sustentação. A análise da técnica moderna, para além do exame de procedimentos alicerçados em teorias isoladas, deve também se estender às relações entre teoria e prática. Isso abre um novo plano de investigação em que é possível associar o surgimento de técnicas recentes a partir de relações mais antigas entre desenvolvimentos teóricos e suas respectivas práticas. Heidegger, por exemplo, sugere que o modo de desvelamento da técnica moderna já estava presente no gênero de representação da ciência moderna, antes mesmo do surgimento das tecnologias modernas enquanto atividades concretas:

O homem na idade da técnica vê-se desafiado, de forma especialmente incisiva, a comprometer-se com o desencobrimento [ou desvelamento]. Em primeiro lugar, ele lida com a natureza, enquanto o principal reservatório das reservas de energia. Em consequência, o comportamento dis-positivo do homem mostrase, inicialmente, no aparecimento das ciências modernas da natureza. O seu modo de representação encara a natureza como um sistema operativo e calculável de forças. A física moderna não é experimental por usar, nas investigações da natureza, aparelhos e ferramentas. Ao contrário: porque, já na condição de pura teoria, a física leva a natureza a ex-por-se, como um sistema de forças que se pode operar previamente, é que se dis-põe do experimento para testar, se a natureza confirma tal condição e o modo em que o faz. (HEIDEGGER, 2002, p.24)

O termo "dis-por" indica o modo de desvelar da técnica moderna, em que

dá-se com propriedade aquele desencobrimento em cuja consonância $\mathrm{O}$ trabalho da técnica moderna des-encobre o real, como dis-ponibilidade. Por isso a técnica não se reduz apenas a uma atividade humana e muito menos a um simples meio desta atividade. A determinação da técnica meramente instrumental e antropológica se torna, em princípio, de menos importância; ajuntar-lhe, depois, uma explicação metafísica tampouco seria capaz de completá-la. (idem)

Sob ótica heideggeriana, a técnica se apresenta como a própria forma de vir a ser dos entes, de maneira que a realidade como tal é apreendida através da ótica tecnocientífica. Ora, a crítica ao positivismo e à sua influência então torna-se indispensável, dado que, para além do plano epistemológico, a generalização da perspectiva instrumental e minimalista da ciência não influencia apenas novos saberes, como também cada aspecto da vida humana. A realidade se 
desvela como "disponível", isto é, como dotada de único sentido: o de possível instrumento para empreendimentos tecnocientíficos em geral.

Nesse sentido, a ética jonasiana foca em dois pontos bastante amplos. Em primeiro lugar, na questão existencial da responsabilidade como modo de ser do homem, isto é, como sentido possível de ser da realidade. A possibilidade da responsabilidade deve ser preservada pelo trabalho fenomenológico de desvelamento deste modo de ser humano, que se funda no próprio aparecer imanente da realidade em suas diferentes formas e finalidades. Este aspecto da teoria jonasiana será melhor explicado adiante. Em segundo lugar, além do resgate dos fins imanentes intrínsecos à natureza, Jonas põe em questão o risco do não-Ser como possível consequência do advento da técnica moderna. Ele reivindica a necessidade do desenvolvimento de uma ética em que a "responsabilidade" em relação à natureza seja um apelo ao dever humano fundado em bases ontológicas.

\section{A NECESSIDADE DE UMA ÉTICA DO FUTURO}

A fundamentação da ética de Jonas começa pelo questionamento de sua necessidade. $\mathrm{O}$ autor preocupa-se com aspecto deixado de lado por éticas anteriores: "a crítica vulnerabilidade da natureza provocada pela intervenção técnica do homem" (JONAS, 2006, p.39). Segundo Jonas, nenhum pensador anterior preparou uma ética para lidar com tal questão em larga escala, isto é, considerando o empreendimento técnico como possível veículo para a extinção de toda a biosfera terrestre. Isto não decorre de suposta "negligência" de teóricos da moral anteriores, mas da impossibilidade de previsão das modificações do agir humano ocasionadas pelo desenvolvimento da técnica e de suas consequências.

Mais especificamente, creio que certas transformações em nossas capacidades acarretaram uma mudança na natureza do agir humano. E, já que a ética tem a ver com o agir, a consequência lógica disso é que a natureza modificada do agir humano também impõe uma modificação na ética. E isso não somente no sentido de que os novos objetos do agir ampliaram materialmente o domínio dos casos aos quais se devem aplicar as regras de conduta em vigor, mas em muitas das nossas ações descortinou uma dimensão inteiramente nova de significado ético, não prevista nas perspectivas e nos cânones da ética tradicional.

As novas faculdades que tenho em mente são, evidentemente, as da técnica moderna. Portanto, minha primeira questão é a respeito do modo como essa técnica afeta a natureza do nosso agir, até que ponto ela torna o agir sob seu domínio algo diferente do que existiu ao longo dos tempos. (Ibidem, p.29)

Como aponta Jonas, a modernidade assinala o ponto decisivo de ruptura com um cenário histórico em que a relação do ser humano com a natureza era notavelmente distinta. Havia uma 
diferença clara entre o âmbito artificial da invenção humana, como a cidade, marcada por permanência que não se sustentava a longo prazo, e o mundo natural, que incluía o ser humano e se caracterizava por sua sustentação inexorável. Em tempos pré-modernos,

sua vida [do ser humano] desenvolveu-se entre o que permanecia e o que mudava: o que permanecia era a natureza, o que mudava eram suas próprias obras. A maior dessas obras era a cidade, à qual ele podia emprestar um certo grau de permanência por meios que inventava e aos quais se dispunha a obedecer. Mas essa permanência, artificialmente produzida, não oferecia nenhuma garantia de longo prazo. [...] Estados erguem-se e caem, dominações vêm e vão, famílias prosperam e degeneram - nenhuma mudança é para durar. No final, na compensação recíproca de todos os desvios passageiros, a condição do homem permanece como sempre foi. (Ibidem, p.33)

Em meio à natureza, o homem erigiu a cidade como plano artificialmente circunscrito de suas invenções e de sua segurança, em oposição ao mundo natural, por vezes ameaçador nas figuras de criaturas desconhecidas e catástrofes naturais. A natureza "não era objeto da responsabilidade - ela cuidava de si mesma e, com a persuasão e a insistência necessárias, também tomava conta do homem: diante dela eram úteis a inteligência e a inventividade, não a ética" (Ibidem, pp. 33-34). Para Jonas, esta discriminação entre os âmbitos natural e artificial não apenas era nitidamente delineada em tempos pré-modernos, como suas características eram também distintas: a natureza seria grandiosa, autossuficiente e perene, as criações humanas, engenhosas, porém marcadas pela limitação frente à imponência da ordem cósmica.

A fragilidade da natureza não teria sido ainda colocada como questão, de modo que "todo o trato com o mundo extra-humano, isto é, todo o domínio da techne (habilidade) era - à exceção da medicina - eticamente neutro, considerando-se tanto o objeto quanto o sujeito de tal agir”. (Ibidem, p.35) A “significação ética dizia respeito ao relacionamento direto de homem com homem, inclusive o de cada homem consigo mesmo [...]" (idem). À existência da natureza como tal não se apresentava risco algum. A ética, por sua vez, limitava-se a abarcar os indivíduos humanos e suas ações de curto horizonte espaçotemporal. As éticas anteriores foram eficientes nas análises dessas ações de reduzida abrangência e nas previsões de suas consequências imediatas. O agir técnico recente do homem, no entanto, faz com que a capacidade humana de influência na realidade ultrapasse amplamente o poder de previsão de seus efeitos. Seu poder causal se estende para além do que o conhecimento pode abarcar com exatidão, algo extremamente preocupante neste caso, dadas as dimensões da ameaça que se anuncia. Toda a natureza se apresenta como objeto sujeito a modificações humanas, de modo que o homem se torna, pela primeira vez na história, responsável pelo conjunto de ecossistemas terrestres em que 
se encontra assim como pelas futuras gerações humanas, as quais dependem de condições favoráveis em seu planeta para existirem.

Jonas busca um novo imperativo ético que dê conta dos problemas colocados pela nova forma de agir humana modulada pela técnica moderna. Ele se volta, primeiramente, para uma das mais célebres tentativas filosóficas de universalidade no caso da ética, o imperativo categórico, de Kant, que afirma: "Aja de modo que tu também possas querer que tua máxima se torne lei geral." (Ibidem, p.47) $\mathrm{O}$ enunciado kantiano traça os limites normativos do conjunto de ações que devem ser realizadas pelo sujeito racional: aquelas que o sujeito, através de sua vontade livre, pode conceber como possivelmente realizadas por todos os outros em circunstâncias similares. Jonas aponta que, no imperativo categórico,

a reflexão básica da moral não é propriamente moral, mas lógica: o "poder" ou "não poder" querer expressa autocompatibilidade ou incompatibilidade, e não aprovação ou desaprovação. Mas não existe nenhuma contradição em si na ideia de que a humanidade cesse de existir, e dessa forma também nenhuma contradição em si na ideia de que a felicidade das gerações presentes e seguintes possa ser paga com a infelicidade ou mesmo com a não existência de gerações pósteras [...]. (Idem)

O imperativo é legitimado pela compatibilidade lógica da universalização da ação em relação a todos os atores da comunidade expressa no “"poder' ou 'não poder' querer do sujeito autônomo. Caso o exercício geral de uma ação por todos os indivíduos implique em contradição, a ação não deve ser posta em prática. Para Jonas, o pressuposto moral kantiano é insuficiente para o propósito de sua ética, a saber, a garantia da existência humana e de suas gerações futuras. Não há contradição na ideia de que a humanidade cesse de existir, por exemplo, ou de que "a existência e a felicidade das gerações futuras seja paga com a infelicidade e mesmo com a eliminação parcial da presente.” (Idem) A universalização perde o valor de legitimação de que é dotada no imperativo kantiano quando considerada do ponto de vista de Jonas, já que, no caso deste último, é colocada em risco a existência da própria comunidade de atores morais em que se daria a universalização.

Jonas propõe outro imperativo: "Aja de modo a que os efeitos da tua ação sejam compatíveis com a permanência de uma autêntica vida humana sobre a Terra." (Idem) A universalização kantiana é caracterizada por Jonas como "hipotética, isto é, a transferência meramente lógica do 'eu' individual para um 'todos imaginário', sem conexão causal com ele ('se cada um fizesse assim')" (Ibidem, p.49) ${ }^{2}$.No caso do imperativo categórico, "o princípio não é

${ }^{2} \mathrm{O}$ estatuto de "hipotética" atribuído por Jonas à universalização do imperativo categórico tem por objetivo a crítica ao modelo lógico a partir do qual se desdobra o imperativo, considerado insuficiente pelo filósofo. $\mathrm{O}$ termo não 
aquele da responsabilidade objetiva, e sim o da constituição objetiva de minha autodeterminação" (ibidem, pp. 48-49). O imperativo jonasiano, em contraste com o formalismo de Kant, concentra-se nas possíveis consequências diretas das ações, sem restrição ao suposto horizonte da autonomia do sujeito manifesta no "poder querer". Neste caso, "as ações do todo coletivo assumem a característica de universalidade na medida real de sua eficácia. Elas ‘totalizam’ a si próprias na progressão de seu impulso, desembocando forçosamente na configuração universal do estado das coisas." (Ibidem, p.49)

Ora, o conceito de liberdade kantiano se segue de sua preocupação em salvaguardar a possibilidade de autodeterminação racional do sujeito frente às concepções deterministas de filósofos de seu tempo, em especial as de David Hume. Para tanto, Kant precisava garantir em sua teoria um lugar para a autonomia subjetiva que não se furtasse ao mecanicismo vigente na modernidade. Jonas, por outro lado, busca fundamentar a garantia de que ações humanas não coloquem em risco a totalidade do planeta e a existência atual e futura de seus habitantes. $\mathrm{O}$ esforço jonasiano não deve ser confundido com a tentativa de estabelecimento de proposições éticas absolutas, inalteráveis com o tempo, mas de ética que inclua em seu escopo a existência de futuras gerações colocadas em risco por práticas realizadas no presente. Daí o enfoque do imperativo de Jonas nos "efeitos de sua ação", para além da mera garantia de autodeterminação do agente moral.

\section{FUNDAMENTAÇÃO ONTOLÓGICA}

Para Jonas, a distinção entre ser e dever pressuposta por "nosso tempo" é equivocada e constitui um dogma: ode que não há verdade metafísica (Ibidem, p.95). Jonas observa que o minimalismo materialista - que postula o ser como separado do dever - pressupõe também uma metafísica:

enquanto não tiver sido demonstrado que a ciência esgota integralmente o conceito de saber não terá sido dada a última palavra sobre a possibilidade da metafísica. Mas, mesmo que assim fosse, admitir que essa contestação não constituiria uma objeção particular contra a ética que buscamos, pois em qualquer outra ética, mesmo naquela mais utilitária, mais eudemonista e mais imanente, também se esconde implicitamente uma metafísica (o 'materialismo', por exemplo, seria uma). Portanto, nenhuma delas apresentaria qualquer vantagem em relação à nossa ética. O que há de particular em nosso caso é apenas o fato de que a metafísica nele presente não pode permanecer oculta, tendo de vir à luz [...]. Pois se também a tese negativa a respeito do "ser e dever" implica uma tese metafísica, o seu defensor pode se abandonar à

deve ser confundido com uma indicação da tradicional distinção kantiana entre imperativo categórico e imperativo hipotético. 
ignorância metafísica partilhada universalmente e refugiar-se na suposta superioridade metodológica da suposição mínima, isto é, da negação sobre a afirmação [da tese de que o dever e o ser são distintos]. Esse refúgio é negado à afirmação, e seu defensor deve se apresentar, senão uma prova, então ao menos um argumento ontológico racional para a sua suposição mais exigente. Portanto, ele necessita do ensaio metafísico, recurso do qual pode se poupar o "minimalista", invocando Ockham. (Ibidem, p.96)

O abandono da metafísica em favor da ciência é qualificado como arbitrário, uma vez que ambas têm como fundo uma concepção positiva de realidade (o que Jonas parece considerar equivalente à noção de metafísica entendida como estudo "do que é"). O mesmo vale para éticas imanentes em geral. A separação entre ser e dever apenas dificulta a tarefa do teórico que busca fundar metafisicamente suas suposições, o qual se vê obrigado a desenvolver um sistema que efetue a ligação entre o que é e o que deve ser. Ele necessita "ao menos de um argumento ontológico racional para a sua suposição mais exigente".

No caso do defensor da distinção dever/ser, basta que ele se refugie na "superioridade ontológica da suposição mínima" e invoque "Ockham”. Jonas faz aqui alusão ao conhecido princípio da parcimônia ou "navalha de Ockham", derivado da obra do filósofo medieval Guilherme de Ockham. O princípio, em sentido metafísico, postula "que devemos acreditar no menor número possível de objetos. Como princípio metodológico, a 'navalha de Ockham' diznos que qualquer explicação deve apelar ao menor número possível de fatos"' (BRANQUINHO, MURCHO e GOMES, 2006, p.536). A navalha, neste caso, é apontada por Jonas como simples instrumento de direcionamento do ônus da prova para o metafísico, que se vê forçado à incursão na ontologia da qual se livra o materialista.

Jonas nega o caráter supostamente ilusório da finalidade e a pensa como bem em si. Ela existe na natureza à medida que esta segue fins, como, por exemplo, a própria vida, que é veículo para a afirmação do Ser sobre o não-ser.

Em cada finalidade o Ser declara-se a favor de si, contra o nada. Contra esse veredicto do Ser não há réplica, pois mesmo a negação do Ser trai um interesse e uma finalidade. Ou seja, o simples fato de que o Ser não seja indiferente a si mesmo torna a diferença de si, em relação ao não-Ser, o valor fundamental de todos os valores; o primeiro 'sim', a princípio. (Ibidem, p.151)

Desta maneira, os próprios seres vivos sensíveis tornam-se afirmadores do ser, uma vez que são fins em si mesmos em sua luta pela sobrevivência a cada momento da ontogênese. Analogamente, a natureza manifesta fins ao dar origem à vida assim como as estruturas de sistemas orgânicos. "[...] na oposição entre o Ser e a morte a afirmação do Ser torna-se enfática." (Ibidem, p.152) Se os seres vivos são fins imanentes por si mesmos, considerá-los como valores é 
dever do homem pois é próprio e exclusivo de seu ser o reconhecimento de tais fins. Ele pode se apropriar deste "bem" presente na natureza e torná-lo sua tarefa, fazendo com que a finalidade, que reivindica sua realização, torne-se para ele um valor. Isto pode apenas ser realizado se o homem fizer também do reconhecido objeto de sua ética alvo de sua vontade.

A "vontade", neste caso, constitui o aspecto afetivo da ética em contraste com sua parte teórica. Jonas faz uma pequena recapitulação da função do sentimento em filosofias morais anteriores:

Os filósofos da moral sempre reconheceram que o sentimento deveria se unir à razão, de modo que o bem objetivo adquirisse poder sobre a nossa vontade; em outras palavras, a moral que supomos que deve se impor às emoções necessita, ela própria, de emoções. [...]. Essa intuição está presente, explícita ou implicitamente, em toda doutrina da virtude, por mais distintas que sejam as formas de definir a emoção em questão. [...] Observamos, além disso, que a maioria dos sentimentos mencionados (mas não todos) são do tipo daqueles inspirados por um objeto (e orientados em direção a ele) que representa um valor supremo, um "bem supremo". Tradicionalmente, esse summum bonum possuía frequentemente a conotação ontológica (um corolário para a ideia de perfeição) de ser algo atemporal, antepondo à nossa mortalidade a sedução da eternidade. O objetivo da ambição ética é, pois, tornar o seu próprio estado semelhante a esse do objeto supremo, "apropriar-se" dele nesse sentido e também fomentar a sua apropriação por parte de outros [...].(Ibidem, p.159)

O sentimento teria em éticas antecedentes a função de ser inspirado por um objeto supremo de caráter atemporal (um "bem") que move o ser humano através do esforço de se assemelhar a esse objeto, sendo o homem, no entanto, limitado por sua realidade temporal e corruptível. Jonas ressalta as similaridades de sua ética em relação às tradicionais, a saber, que "a força impositiva surge como o principal concernido de sua ética um objeto, e a ligação [do agente moral] é com o objeto, seja eterno ou temporal" (Ibidem, p.160). A alternativa proposta por Jonas é também direcionada a um objeto, mas este é perecível, carrega em si o risco da nãoexistência. Demanda, de sua fragilidade, o que Jonas denomina responsabilidade.

Jonas diferencia duas perspectivas principais sobre a responsabilidade. Esta é fundada essencialmente no poder causal, ou seja, na noção de que:

o agente deve responder por seus atos: ele é responsável por suas consequências e responderá por elas, se for o caso. [...] Basta que [...] tenha sido a causa ativa. Mas isso somente se houver um nexo causal estreito com a ação, de maneira que a imputação seja evidente e suas consequências não se percam no imprevisível (Ibidem, p.165)

Em um primeiro olhar, a responsabilidade tem conotação moral ou legal, cujo principal objetivo é a reparação de danos causados por consequências do agente. Neste caso, ela diz 
respeito às decorrências de uma ação quando determinadas após sua execução. A responsabilidade que nos interessa é de outro gênero:

Há outra noção de responsabilidade que não concerne ao cálculo do que foi feito expost facto, mas à determinação do que se tem a fazer; uma noção em virtude da qual eu me sinto responsável, em primeiro lugar, não por minha conduta e suas consequências, mas pelo objeto que reivindica meu agir. [...] $\mathrm{O}$ "porquê" [o alvo dessa responsabilidade] encontra-se fora de mim, mas na esfera de influência do meu poder, ou dele necessitando ou por ele ameaçado. Ao meu poder ele contrapõe o seu direito de existir como é ou poderia ser, e com a vontade moral ele submete o meu poder. (Ibidem, p.167)

Neste caso, a responsabilidade não tem por função a culpabilização com finalidade de reparação de ordem anterior à execução da ação, mas a legitimação da potencia das atividades desempenhadas pelo ator. Objetos concernidos pelo horizonte causal de suas ações são, portanto, dignos de responsabilidade antes mesmo da efetuação dessas ações de maneira que o dever decorre do poder de atuação. As duas formas principais dessa responsabilidade são a política, de cunho estatal e artificial, e a dos pais em relação a seus filhos, imputada pela própria natureza (Ibidem p.173). Jonas reconhece essa última forma como arquetípica para a essência da responsabilidade.

Abre-se caminho para uma "responsabilidade ontológica pela ideia do homem" (Ibidem, p.94), cujo peso não cai sobre os homens futuros por si próprios, mas sobre a ideia de homem que já inclui a presença de sua concretude no mundo. O ser humano é tomado então não como ente substancial fechado em si mesmo, mas como integrante do conjunto total de significação constituído pelos elementos que compõem o mundo. A existência humana deve ser preservada, pois traz consigo um "dever ser", a saber, o dever de sua manutenção enquanto possibilidade de ser o que acaba por implicar também a continuação existencial de seu mundo, imprescindível para essa possibilidade.

O recém-nascido é arquetípico para tal responsabilidade, pois é o que traz esse "dever ser" de modo mais imediato. Ele representa a maneira mais radical da fragilidade presente em todos os seres vivos engajados na conservação de suas próprias existências e sujeitos à degradação temporal. Como diz Jonas, o recém-nascido "reúne em si a força do já existente, que se autorreconhece, e a queixosa impotência do 'não ser ainda'; o incondicional fim em si de todos os viventes e o 'ainda ter de se tornar' das suas próprias capacidades, para garantir esse fim." (Ibidem, p.223) O apelo da existência do recém-nascido deve ser atendido uma vez que lhe falta autossuficiência para a satisfação de suas necessidades básicas. Trata-se aqui de manutenção da possibilidade da responsabilidade, já que, quando completado o desenvolvimento da criança, ela própria será locatária da responsabilidade incontornável oriunda de sua humanidade. Isso, é claro, 
dependerá de que seus progenitores ou responsáveis atendam a este "dever" pelo reconhecimento da finalidade que lhe é de direito, o que ocasiona um "bem" a ser mantido.

Deve haver a coincidência da constatação intelectual desse "bem" e do sentimento de responsabilidade para com a tarefa de sua manutenção no mundo. Jonas reconhece isso como essencial para a ação moral pois, apesar de éticas sustentadas por preceitos racionais, e de seu pleno reconhecimento pelo sujeito ético, sem o sentimento de responsabilidade em relação ao objeto não pode haver ação alguma. A vontade aparece, assim, como condição afetiva necessária para a ação que constitui seu objetivo último. O poder, então, junta-se ao dever e este, por sua vez, enraíza-se no ser.

\section{CONCLUSÃO}

Para Hans Jonas, o atual funcionamento da técnica moderna traz grandes riscos para a existência tanto da natureza como do ser humano. Os resultados de sua aplicação não podem ser previstos com exatidão em virtude de seu descomunal alcance espacial e temporal. Faz-se necessária a elaboração de uma ética para a reivindicação da prudência em relação aos atos do homem. Sua fundamentação metafísica se alicerça na existência de valores objetivos próprios da natureza, embasada em finalidades imanentes em si. Estas carregam o dever de sua realização, que é um apelo para o homem, único vivente dotado de poder para atender ao chamado da responsabilidade. Este deve assim ser incentivado por um "dever ser" próprio dos viventes, que, por sua própria existência e luta pela vida, constantemente reafirmam o Ser. São fins em si mesmos.

É necessário, portanto, garantir a possibilidade das futuras gerações pois, com o advento da técnica moderna, o não-Ser tornou-se possível. Sendo assim, o dever da preservação da própria ideia de ser humano é o primeiro imperativo do qual se derivam todos os outros. Do ser provém uma responsabilidade para com o homem que, por sua vez, carrega consigo a possibilidade futura da própria responsabilidade.

\section{BIBLIOGRAFIA:}

ANDRADE, Ricardo Jardim. A gênese do conhecimento segundo Heidegger. Reflexão, ano VII, n. 23, maio/agosto/1982.

BRANQUINHO, João; MURCHO, Desidério; GOMES, Nelson Gonçalves. Enciclopédia de termos lógico-filosóficos. São Paulo: Martins Fontes, 2006. 
COMTE, Auguste. Curso de filosofia positiva, trad. Coleção “Os Pensadores”, São Paulo: Abril Cultura, 1973.

DARTIGUES, Andre. O que é fenomenologia?. $3^{a}$ ed. Trad. Maria José de Almeida. São Paulo: Moraes, 1992.

HEIDEGGER, Martin. Ser e Tempo. 10ª ed. Petrópolis: Vozes, 2006.

HEIDEGGER, Martin.Ensaios e conferências. 8ª ed. Petrópolis: Vozes, 2002.

HUSSERL, Edmund. La crise des sciences européenes et la phénoménologie transcendentale. trad. Fr. Paris: Gallimard, 1976.

JONAS, Hans. O Princípio Responsabilidade: Ensaio de uma ética para a civilização tecnológica.Rio de Janeiro: Contraponto: Editora PUC-Rio, 2006.

JONAS, Hans. Técnica, medicina e ética: sobre a prática da responsabilidade. Tradução do Grupo de Trabalho Hans Jonas da ANPOF. São Paulo: Paulus, 2013.

SHULL, K.K. Is the Magic Gone? Weber's "Disenchantment of the World" and its Implications for Art in Today's World. Anamesa, New York, v.3, i. 2, p.61, fall. 2005. 


\title{
SOBRE A CONSISTÊNCIA INTERNA DA ÉTICA DE HANS JONAS
}

On the intern consistency of Hans Jonas' Ethic

Guilherme T. M. Schettini Mestrando - UFRJ (Bolsa Capes)

RESUMO: Neste artigo, avaliaremos a consistência interna da Ética de Hans Jonas a partir das seguintes questões: i) Da anterioridade do Princípio Vida em relação ao Princípio Responsabilidade, e dos problemas que isso evita; ii) Do imperativo categórico de Jonas, e dos problemas que isso engendra; iii) Da suposta instrumentalização da vida humana pela Ética de Jonas; e iv) Do suposto caráter híbrido (deontológico e teleológico) da Ética de Jonas.

PALAVRAS-CHAVE: Hans Jonas; Consistência; Lógica.

\begin{abstract}
This article analyzes the consistency of Hans Jonas Ethics and is based on the following questions: (i) the antecedence of the Phenomenon of Life in relation to the Imperative of Responsibility, and the problems it avoids; (ii) the categorical imperative of Jonas, and the problems it engenders; (iii) the supposed instrumentation of human life by Jonas's Ethics; and (iv) the supposed hybrid character (deontological and teleological) of the Ethics of Jonas.
\end{abstract}

KEYWORDS: Hans Jonas; Consistency; Logic.

\section{APRESENTAÇÃO}

Tendo em vista as questões abordadas no curso Filosofia Social $I I^{1}$ e, é claro, a nossa formação em Filosofia, que, a despeito de genérica, tem dado ênfase na chamada Filosofia Analítica, pretendemos analisar aqui, sob quatro aspectos distintos, a consistência interna da Ética de Hans Jonas.

Por consistência interna de uma dada teoria entendemos a propriedade lógica que nos impede de chegar a conclusões contraditórias com os postulados da teoria dada. No caso da Ética de Jonas, os seus postulados (ou, em um linguajar menos técnico, os seus pilares)

\footnotetext{
${ }^{1}$ Curso oferecido pela professora Sarah Moura no Instituto de Filosofia e Ciências Sociais da UFRJ, entre outubro de 2015 e março de 2016.
} 
mais evidentes são o Princípio Vida e o Princípio Responsabilidade. Portanto, se é o caso de não sermos conduzidos, a partir dos pilares da Ética de Jonas, a nenhuma proposição falsa, vale dizer, negadora de algum desses pilares, estamos diante de uma teoria consistente (ou, o que é o mesmo, de uma teoria provida de correção lógica); se, ao contrário, a alguma dessas proposições "problemáticas" somos conduzidos, deparamo-nos com um caso de inconsistência lógica.

De antemão, é necessário precaver o leitor para a insuficiência deste trabalho. Ainda não estabelecemos um contato mais amplo com a obra de Jonas (a bem da verdade, o que sabemos desse filósofo se deve à esclarecedora Da ontologia da vida a uma ética para a civilização tecnológica, de Sarah Moura (Cf. MOURA)), pelo que não podemos, com o mínimo de bom senso, asseverar a consistência ou a inconsistência de sua teoria, pelo menos de uma forma que pareça geral e definitiva. Ademais, ainda que dispuséssemos de todo o conhecimento que possa haver sobre este autor, não é de nosso feitio proclamar veredictos dessa ordem.

Os nossos propósitos são, inversamente, muito modestos. Restringiremos a atenção a quatro questões que nos foram suscitadas no decorrer do curso e da leitura do texto de Sarah. São elas: i) Da anterioridade do Princípio Vida em relação ao Princípio Responsabilidade, e dos problemas que isso evita; ii) Do imperativo categórico de Jonas, e dos problemas que isso engendra; iii) Da suposta instrumentalização da vida humana pela Ética de Jonas; e iv) Do suposto caráter híbrido (deontológico e teleológico) da Ética de Jonas. É apenas sobre estas questões (que dão título a cada um dos itens da seção seguinte) que julgamentos do tipo "isto é consistente" ou "isto é inconsistente" irão incidir neste trabalho (especificamente, na seção das considerações finais).

Se, no entanto, são estas questões pertinentes ou não à obra de Jonas, e, por tabela, potencialmente comprometedoras ou não de sua teoria como um todo, isto fica a critério dos que melhor entendem desse autor.

\section{DESENVOLVIMENTO:}

2.1. Da anterioridade do Princípio Vida em relação ao Princípio Responsabilidade, e dos problemas que isso evita:

Pode-se dizer que os dois pilares metafísicos da Ética de Hans Jonas são o Princípio Vida e o Princípio Responsabilidade. Diante deste binarismo original, é natural 
perguntar se estes princípios são independentes ou dependentes, e, no último caso, se há uma hierarquia entre eles.

Pelo Princípio Vida, Jonas postula a "unidade psicofísica” da vida humana, isto é, a vida humana é concebida como a continuidade e a interdependência entre a mente e o organismo, e entre o organismo e a natureza. De imediato, o que nos interessa aí é a defesa de uma "visão sistêmica" da vida: com efeito, esta não pode ser concebida de uma forma separada da natureza.

De sua parte, o Princípio Responsabilidade postula o dever com o Ser (e talvez aqui possamos grosseiramente reduzir a palavra "Ser" à palavra "vida") em oposição ao nada, e isto implica o dever (da humanidade) de, por meio de suas ações, garantir as condições para uma vida autêntica no presente e no futuro. A ação responsável é vista, pois, como o requisito mínimo para a garantia da vida humana, e o ser humano é entendido como naturalmente orientado à preservação da vida (ainda que, muitas vezes - sobretudo da Era Moderna para cá -, pareça agir contra a sua própria natureza).

Aqui nos interessa saber se o Princípio Vida é anterior ao Princípio Responsabilidade, ou se este é anterior àquele (ou, ainda, se ambos são independentes). Ora, durante o curso que acabamos de realizar, uma das principais críticas dirigidas a Jonas foi a do suposto caráter antropocêntrico de sua Ética: Jonas estaria muito preocupado com a preservação da vida humana no futuro, mas pouco ou nada falaria da preservação da vida de todas as outras espécies sobre a Terra, pelo que seria no mínimo negligente, por exemplo, com o maltrato aos animais.

Isto nos parece uma confusão diretamente derivada do problema de que tratamos nesta seção. Se analisarmos o Princípio Responsabilidade isoladamente, talvez até estejamos autorizados a endossar o suposto antropocentrismo de Jonas: de fato, pelo menos no "imperativo categórico" (de que trataremos no item seguinte, mas que, por agora, podemos enunciar como "aja de tal maneira que os efeitos dos seus atos possibilitem a vida humana autêntica das gerações futuras") que norteia este Princípio, Jonas aparentemente preocupase apenas com a preservação da espécie humana.

Mas em que circunstâncias poderíamos analisar o Princípio Responsabilidade isoladamente? Ora, até onde nos permite a Lógica, em apenas duas: (i) se o Princípio Vida e o Princípio Responsabilidade fossem independentes; e (ii) se o Princípio Responsabilidade fosse anterior ao Princípio Vida. Em qualquer um desses casos, interpretaríamos a expressão "vida humana", tal como se encontra no "imperativo categórico" acima exposto, 
da maneira mais convencional possível: ela designaria a vida da espécie humana, vale dizer, do homo sapiens, e só desta.

Se, no entanto, o Princípio Vida fosse concebido como anterior ao Princípio Responsabilidade (em tempo: a "anterioridade" a que nos referimos é puramente lógica, isto é, não implica nenhuma supremacia de ordem prática de um princípio sobre o outro; talvez seja o caso de se pensar que ambos os princípios são igualmente relevantes para a Ética de Jonas), este mal entendido seria desfeito: neste caso, não poderíamos mais interpretar a expressão "vida humana", tal como exposta no "imperativo categórico", de uma maneira convencional; ela passaria a ter o significado preciso que encontramos no "Princípio Vida". E que significado é este? Ora, já vimos: a de vida humana como uma unidade psicofísica inseparável da natureza. Preservar a vida humana pressupõe e implica, portanto, preservar a natureza (com todas as espécies que ela contém).

Assim, parece-nos necessário conceder uma anterioridade lógica ao Princípio Vida sobre o Princípio Responsabilidade. A própria ordem em que Jonas os apresenta em sua obra já nos indica isso (o Princípio Vida foi primeiramente publicado em 1966; o Princípio Responsabilidade, em 1978). Ademais, o título da dissertação de Sarah, Da ontologia da vida a uma ética para a civilização tecnológica, nos autoriza a mesma interpretação.

2.2. Do imperativo categórico de Jonas, e dos problemas que isso engendra:

A máxima com que podemos sintetizar o Princípio Responsabilidade de Hans Jonas, "aja de tal maneira que os efeitos dos seus atos possibilitem a vida humana autêntica das gerações futuras", apoia-se, como vimos, em uma "visão sistêmica" da vida humana. Esta parece ser uma concepção de vida diretamente inspirada nas ideias do evolucionista Charles Darwin, que, grosso modo, defendia a tese de que a mudança das espécies naturais ocorria em consonância com o meio ambiente, em um processo denominado "seleção natural". Mas não será problemático fundar a Ética na Biologia?

As proposições da Biologia, como de qualquer ciência, são revisáveis. No Princípio Vida, o próprio Jonas nos informa das diferentes concepções de vida ao longo da História: à visão sistêmica e evolucionista dos contemporâneos, antecederam a visão mecanicista dos modernos, a visão criacionista dos medievais e a visão panvitalista dos antigos. Por que será a nossa visão a correta?

Em outras palavras, se as melhores teorias do passado foram refutadas, o que nos garante que um dia a nossa não será também refutada? Esta dúvida, conhecida na Filosofia 
como indução pessimista de Montaigne, não nos advertiria para o risco de se sustentar a Metafísica, que, por definição, é uma disciplina que trata de proposições eternas e universalmente válidas, nas ciências naturais cambiantes?

O ponto exato a que queremos chegar é o seguinte: será que não se afigura a Jonas a possibilidade de, com o passar do tempo, o próprio entendimento do que seja uma "vida humana autêntica" se transformar? E se, como advogam os mais entusiastas da Inteligência Artificial, a "vida humana" não passar de um algoritmo possível de ser reproduzido em um programa de computador? Ainda que hoje esta nos pareça uma tese extravagante, com que certeza podemos asseverar a sua falsidade absoluta, e, neste cenário hipotético, de que valeriam as preocupações de Jonas quanto à preservação da vida futura?

A resposta a todas estas questões só pode ser sincera: com efeito, Jonas é um filósofo do seu tempo (ou melhor, do nosso tempo, já que o seu tempo é o nosso), e não é mais pretensão de nossa Filosofia, ao contrário do que talvez tenha sido até a Idade Moderna, chegar ao conhecimento “certo, indubitável, eterno e imutável”. A Ética de Jonas, ao seguir a concepção sistêmica de vida, ainda que corra o risco de se apoiar em um terreno instável, a saber, o das crenças científicas, cumpre a sua função maior de oferecer princípios para as ações humanas, princípios estes que, diga-se de passagem, até agora não se revelaram problemáticos do ponto de vista lógico.

\subsection{Da suposta instrumentalização da vida humana pela Ética de Jonas:}

Pensemos, uma vez mais, no imperativo categórico de Jonas. Não haverá nesta asserção uma ideia instrumentalizada da vida humana, isto é, Jonas não estará concebendo a vida dos que vivem hoje (nós, nomeadamente) como um simples meio para a vida dos que virão no futuro?

Cumpre de imediato observar que certamente o indivíduo Hans Jonas pensava no ser humano como tendo um fim próprio, e na vida humana, por conseguinte, como tendo um fim próprio. A certeza com que asseveramos isso é resultante do curso que acabamos de realizar, e do contato mais amplo com as ideias do autor que tivemos nesse curso. Mas, olhando apenas para o imperativo categórico de Jonas (pois, para quem investiga a consistência de uma teoria, variáveis como o contexto não são relevantes, mas apenas as proposições dessa teoria - como nos ensinou Derrida, não há nada fora do texto), não será oportuno perguntar coisas como as do parágrafo precedente? 
Para por lenha nesta fogueira, e também aproveitando-nos de uma escrita mais madura do que a nossa, vejamos a posição de quem, pelo menos no terreno da Ética, diverge consideravelmente das ideias de Jonas, ainda que não faça referência direta a este filósofo: Miguel de Unamuno. Em seu Sentimento Trágico da Vida, nos diz Unamuno:

O homem é um fim, não é um meio. A civilização toda se endereça ao homem, a cada homem, a cada "eu". Que ídolo é este, chame-se Humanidade ou o que se queira, a que hão de se sacrificar todos e cada um dos homens? (...) Quem recebe o fruto desse sacrifício?

Os mesmos que nos falam desse sacrifício fantástico, dessa dedicação sem objeto, costumam também falar-nos do direito à vida. Mas o que é o direito à vida? (UNAMUNO. Del sentimiento trágico de la vida. Capítulo 1. Tradução nossa $\left.{ }^{2}\right)$

Ainda que, por diversas razões, nos sintamos muito mais atraídos pelo pensamento de Jonas do que pela filosofia de Unamuno, há algo no argumento deste filósofo que merece consideração, sobretudo se confrontado com a máxima de Jonas: trata-se da questão "quem recebe o fruto desse sacrifício?".

De fato, no caso da atual geração agir sempre com vistas à manutenção da vida autêntica no futuro, e isso exigirá, é evidente, a privação de muitas das coisas que ela se acostumou a ter, ou que poderia ter mas, em face da preocupação com o futuro, não terá, quem receberá o fruto desse sacrifício? Poder-se-ia apressadamente dizer: ora, as próprias gerações futuras serão as beneficiadas, dado que terão a sua existência autêntica garantida. Mas, alto lá: estas não terão também que seguir o imperativo de Jonas, e, portanto, não terão também que se sacrificar? (pois, ao que consta, não há uma data de validade para este imperativo). E as gerações seguintes, por sua vez, não terão que se sacrificar em nome das vindouras?

É fácil observar que a dinâmica anterior nos conduz ao infinito, e, infelizmente, parece deixar sem resposta a pergunta de Unamuno. Antes de esboçarmos alguma solução para este problema, mencionemos um último contra-argumento à Ética de Jonas, já bastante conhecido dos estudiosos desse autor: como falar em direitos para as gerações futuras (pensemos no direito à vida autêntica, para nos restringirmos ao imperativo categórico), se estas gerações concretamente não existem, isto é, se elas só existem enquanto possibilidade?

\footnotetext{
${ }^{2}$ Infelizmente, possuímos apenas uma versão digitalizada de Sentimiento Trágico de La Vida. Nesta versão, não consta quem digitalizou o livro, nem em qual edição se apoiou - isto é, o texto é apresentado diretamente e sem nenhuma referência à edição impressa. Desculpamo-nos, assim, pela ausência de indicação das páginas citadas, uma vez que tampouco encontramos o material digitalizado na internet, e informamos que a primeira publicação do livro ocorreu em 1913.
} 
Este é, sem dúvida, um agravante para os contra-argumentos anteriores: além de instrumentalizar a vida humana, o imperativo categórico de Jonas não estaria instrumentalizando-a para uma coisa que não existe e nem se sabe se existirá? Mas a questão dos direitos (ou melhor, da ausência deles) para as gerações futuras não é um problema de ordem lógica, ou seja, não diz respeito à consistência interna da teoria de Jonas, pelo que escapa à alçada deste trabalho (ademais, parece-nos de fácil solução: com efeito, agimos muitas vezes na vida com vistas a algo que ainda não existe, mas que supomos que existirá, e nem por isso deixamos de agir corretamente).

A questão que nos ocupa é, pois, a da suposta instrumentalização da vida humana. E aqui são duas as saídas possíveis: (i) podemos dizer que a preocupação com o bem das gerações futuras já implica, em certo sentido, a preocupação com o nosso próprio bem; vale dizer, ao agirmos com vistas à preservação da vida autêntica no futuro, já estamos resguardando a nossa própria vida autêntica; e (ii) podemos dizer que o apelo às gerações futuras é apenas um artifício psicológico utilizado por Jonas para sensibilizar os contemporâneos a fazer o que é necessário.

Quanto a este último ponto, cabe mais uma palavra: talvez seja o caso de se pensar que proposições do tipo "o planeta está sendo destruído", "a nossa vida está em perigo" etc. não convençam o público para a necessidade da ação comedida e razoável. Queremos dizer: talvez o ser humano não tenha amor próprio. Se isso for mesmo verdade, não há outra solução senão a adotada por Jonas: que apelemos, então, para o futuro de nossos filhos e descendentes.

2.4. Do suposto caráter híbrido (deontológico e teleológico) da Ética de Jonas:

No campo da Ética, há duas perspectivas teóricas que poderíamos chamar de clássicas (sem querer com isso, no entanto, remeter exclusivamente à filosofia grega): a perspectiva deontológica e a perspectiva teleológica. Com qual destas duas grandes perspectivas se aliará a Ética de Jonas?

Ora, vejamos primeiro o que diz cada uma dessas perspectivas. Em linhas gerais, a perspectiva deontológica se fundamenta na noção de dever, pelo que reúne se assim podemos falar, todas as "éticas dos deveres". Para estes sistemas, só há dois valores possíveis de verdade: o "certo" e o "errado". A perspectiva deontológica corresponde, 
portanto, à perspectiva das normas, e engloba todas as proposições do tipo "deve-se fazer X”, em que fazer X é “certo" e não fazer X é “errado”.

A perspectiva teleológica, por sua vez, se fundamenta na noção de fim (finalidade) e, muitas vezes, também na noção de bem, e tem como exemplo mais conhecido o utilitarismo de Stuart Mill. Para esta concepção, são vários os valores possíveis de verdade (digamos, o "excelente", o "melhor", o "razoável”, o "pior”, o “péssimo” etc.). A perspectiva teleológica corresponde, portanto, à perspectiva dos valores, e engloba todas as proposições do tipo "é melhor fazer X".

Se considerarmos uma vez mais (e pela última vez!) o imperativo categórico de Jonas, nos parecerá evidente alocar a sua Ética na perspectiva deontológica, pois agir com vistas à preservação da vida autêntica no futuro, antes de um valor, é um dever para Jonas. Além do mais, a proposição que expressa o imperativo categórico não comporta vários valores de verdade, mas apenas dois: o "certo" e o "errado" (é "certo" se preocupar com as gerações futuras, e é "errado" não fazer isso).

No entanto, considerando a obra de Jonas no seu todo, são vários os indícios de que a sua Ética comporta vários valores de verdade, e que se adéqua, portanto, a uma perspectiva teleológica. Por exemplo, ao criticar os regimes capitalista e socialista, atribuindo ao último um valor moral superior ao primeiro, mas, ao fim e ao cabo, condenando-o também pela sua obsessão com noções como o "progresso" e a "utopia", Jonas, a despeito de apontar para a insuficiência de ambos os sistemas no que se refere à preservação da autenticidade da vida futura, parece fazer uma distinção entre um "mal mais condenável” e um "mal menos condenável".

Estes matizes se manifestam de maneira ainda mais evidente nas medidas defendidas por Jonas para o combate à destruição do planeta, dentre as quais o desenvolvimento de fontes alternativas de energia e a diminuição do nível de consumo se destacam. Nestes casos, é de se presumir que, para a Ética de Jonas, quanto mais um Estado desenvolver alternativas energéticas e reduzir o nível de consumo, melhor será, e quanto menos o fizer, pior será, mas que não há um ponto fixo a partir do qual se diga: este Estado faz o "certo" ou este Estado faz o "errado".

Chegamos, assim, a uma aparente incoerência: a Ética de Jonas parece aliar-se ora à perspectiva deontológica, ora à perspectiva teleológica. Como sairemos desta emboscada?

Ora, sairemos de uma maneira muito simples: com efeito, se alguém nos abordasse com uma questão desse tipo, replicaríamos: “a rigor, o que nos obrigaria a 'encaixar' a Ética de Jonas em uma destas duas perspectivas? Qual seria o constrangimento lógico de que se 
elaborasse uma nova perspectiva na qual, para algumas proposições, fossem apenas dois os valores de verdade, e para as demais, fossem vários os valores de verdade? E, neste caso, a Ética de Jonas não seria satisfeita? Ora, a sua dúvida, meu caro interlocutor, parece deveras artificial".

\section{CONSIDERAÇÕES FINAIS}

Volvidas todas as etapas anteriores, é hora de avaliar a consistência interna da teoria de Hans Jonas relativamente aos aspectos levantados. Examinemos, pois, se efetivamente neste trabalho fomos conduzidos a alguma contradição, ou se, ao contrário, a partir dos pilares da Ética de Jonas, todas as proposições daí derivadas coadunaram com estes pilares.

Quanto ao primeiro ponto, Da anterioridade do Princípio Vida em relação ao Princípio Responsabilidade, e dos problemas que isso evita, vimos que, se por algum descuido, considerássemos o Princípio Responsabilidade isoladamente, isto é, ignorando o Princípio Vida, talvez pudéssemos derivar daí a crença de que a Ética de Jonas está apenas preocupada com a preservação da autenticidade da vida humana, e, portanto, desinteressada na preservação do restante da natureza (em uma palavra, que a Ética de Jonas é antropocêntrica). Esta conclusão seria, sem dúvida, contraditória com o Princípio Vida (caso o considerássemos depois), pelo que poderíamos atestar a inconsistência da teoria de Jonas. Ora, mas não há nada que nos autorize a considerar o Princípio Responsabilidade isoladamente (ou antes do Princípio Vida). A ordem com que estes princípios foram desenvolvidos pelo filósofo e o próprio título da dissertação de Sarah nos indicam o sentido inverso. Postulando a anterioridade do Princípio Vida em relação ao Princípio Responsabilidade, vale dizer, com esta precaução (pois a precaução também é bemvinda nas teorias), não chegaremos de forma alguma àquela conclusão contraditória.

No segundo item, Do imperativo categórico de Jonas e dos problemas que isso engendra, não chegamos a apontar, a bem da verdade, para nada que pudesse comprometer a consistência da Ética de Jonas. A questão que nos ocupou ali foi a de uma possível mudança de um paradigma das ciências biológicas, nomeadamente da teoria evolucionista de Darwin. No hipotético caso desta teoria ser suplantada por outra (como tantas vezes, na história das ciências, uma teoria foi suplantada por outra, numa dinâmica que não perdoou nem as melhores teorias do passado), e tendo em vista a inspiração direta do Princípio Vida no Evolucionismo de Darwin, a Ética de Jonas correria o risco de ficar defasada, sobretudo no entendimento do que seja uma "vida humana autêntica". Mas, há aqui que admitir, este 
seria apenas um problema de ordem prática; em termos estritamente lógicos, não é relevante se uma teoria filosófica é ou não "antenada" com as crenças científicas do momento.

Uma questão mais grave, no entanto, foi levantada em Da suposta instrumentalização da vida bumana pela Ética de Jonas. Com efeito, para que entendamos bem o problema, é primeiro preciso supor que, somado ao Princípio Vida e ao Princípio Responsabilidade, o que aqui chamaremos de Princípio de Toda Ética, a saber, "que o homem é um fim, não é um meio", constitui também um pilar da Ética de Jonas, ainda que implicitamente. Ora, se é assim, a proposição pela qual expressamos o imperativo categórico de Jonas é aparentemente negadora deste princípio (pois, por esta expressão - repetimos, por esta expressão -, o primeiro e único dever do ser humano é o de agir com vistas às gerações futuras, proporcionando-lhes condições para uma vida autêntica). Vimos, no entanto, que há pelo menos duas saídas possíveis para esta suspeita: a primeira é a de pensar que, ao agir com vistas às gerações futuras, o ser humano já estaria proporcionando o seu próprio bem (neste caso, ele continuaria sendo o seu próprio fim), e a segunda é a de supor que o apelo às gerações futuras é apenas um artifício psicológico utilizado por Jonas, artifício este que certamente veicula emoções, mas cujo valor cognitivo (e, portanto, teórico) deve ser desconsiderado.

Como o imperativo categórico de Jonas parece ser afeito às polêmicas, tratamos também dele na quarta seção, intitulada Do suposto caráter bíbrido (deontológico e teleológico) da Ética de Jonas. Mas esta questão revelou-se bastante artificial. Com efeito, caso considerássemos que toda teoria ética é ou deontológica ou teleológica, e que não há, portanto, nenhuma outra perspectiva sobre a qual possa se apoiar, o fato da Ética de Jonas possuir às vezes dois valores de verdade, às vezes vários valores de verdade, constituiria um real problema de inconsistência lógica. Mas não há por que considerarmos estes absurdos.

Então, perpassadas estas questões, não podemos concluir nada diferente disto: a teoria ética de Hans Jonas está longe de ingênua e, de fato, no que fomos capazes de analisar, nos parece consistente do ponto de vista lógico. A consistência interna, longe de ser uma propriedade apenas relevante para os sistemas formais da Lógica, é o requisito mínimo que toda teoria filosófica deve cumprir. O máximo a que pode aspirar uma teoria é, além de ser consistente, ser completa (isto é, além de só alcançar verdades, alcançar todas as verdades do domínio de que trata), mas há sérias dúvidas sobre a viabilidade disso (mesmo nas teorias matemáticas). Por isso, neste trabalho, restringimos a atenção à correção da teoria de Jonas, deixando para uma outra oportunidade a investigação de sua completude. 


\section{REFERÊNCIA}

MOURA, Sarah. Sobre a Ética do Futuro, de Hans Jonas. Dissertação de Mestrado. Rio de Janeiro: UFRJ, 2013. 


\title{
CAMINHOS E DESCAMINHOS ENTRE O PRINCÍPIO DA RESPONSABILIDADE E O ÜBERMENSCH
}

\author{
Paths and astray patbs between The Imperative of Responsibility and The Übermensch
}

\author{
José Jaime da Silva \\ Mestrando em População, Território \\ e Estatísticas Públicas da Escola \\ Nacional de Ciências Estatísticas - \\ ENCE/IBGE.
}

RESUMO: O objetivo deste trabalho é mostrar os pontos de encontro entre o princípio da responsabilidade (Hans Jonas) e o conceito de Übermensch (Nietzsche). O impacto da Revolução Industrial com aumento das riquezas e o rápido avanço técnico deu esperanças de que a técnica traria um progresso contínuo. Nessa euforia surge Nietzsche criticando esse modo de ver a realidade, denunciando as falsas ideias da modernidade. A crítica nietzschiana à modernidade se dá na denúncia que ele faz dos ideais da modernidade: a razão, progresso técnico-científico, sociedade justa e livre, etc. No séc. XX o mundo ocidental sofreu com as falhas de seus projetos ideológicos na política, na economia, no trabalho, etc. As promessas de mundo melhor ficaram por terra depois de catástrofes no séc. XX que desembocam em uma crise ambiental que é vista por pesquisadores como grande ameaça à existência humana. Hans Jonas propõe que o agir humano seja de tal forma que a permanência de uma autêntica vida humana na terra seja garantida. Jonas deixa de lado uma ética metafísica e abre espaço para uma ética na imanência. O Übermensch de Nietzsche que afirma a vida pode ser entendido como seguidor de seus instintos e ligado a natureza, logo um homem sensível aos problemas ambientais. Um desencontro entre os conceitos podem ser as ideias de bem e mal que estão no princípio da responsabilidade, um encontro seria a transformação do medo em coragem que conduz a ação que superaria a crise ambiental. Ambos os autores não chegaram necessariamente no mesmo lugar por caminhos diferentes.

PALAVRAS-CHAVE: Responsabilidade; Übermensch; meio-ambiente. 
Os primeiros filósofos da era moderna (século XVI) desenvolveram a compreensão de que o homem poderia conhecer rigorosamente a natureza através da ciência moderna e com a aplicação deste conhecimento controlar os movimentos daquela em proveito da vida humana e do melhoramento da organização entre os homens. A tese de Bacon de que "saber é poder" mostra bem o clima desta época. À frente destes ideais está uma maneira inédita (empírica, compartimentada, quantificada) de conhecer a realidade.

Se Galileu afirma que "a natureza está escrita em linguagem matemática" (pensamento simplificador e quantificador), e Descartes nos propõe a razão para a sua conquista em nome do ego cogito, Bacon elabora um método para dominar a natureza, "obrigá-la a dar respostas", fazendo-a "serviçal, escravizando-a" (Bacon). Diante disso tudo, o antigo conceito da Terra como mãe nutriente cai literalmente "por terra". O olhar sobre a vida torna-se rígido e mecanicista. ${ }^{1}$

Segundo Pelizzoli a partir da Revolução Cientifica a razão adquire a capacidade de reduzir o mundo em várias categorias e essa mesma racionalidade daria a possibilidade de conhecer as leis que regem a natureza. Assim a ciência moderna poderia dar ao homem a capacidade de reproduzir, modificar e controlar os fenômenos da natureza em via de enriquecer materialmente o ser humano.

No século XIX o impacto da Revolução Industrial no mundo ocidental com o enriquecimento material e o rápido aprimoramento técnico alimentou a esperança de que as descobertas da ciência e os avanços da técnica trariam um progresso contínuo para a vida humana na terra ${ }^{2}$. Em meio a essa euforia por progresso surge Nietzsche criticando esse modo esperançoso de olhar para a realidade de sua época, denunciando as falsas ideias da modernidade e desmentindo as estimativas para o futuro.

Um tema pertinente na filosofia dele, apontado por Giacoia, é que "o domínio do homem sobre a natureza traz consigo a possibilidade, senão a inexorabilidade, da superação do homem"3. Ao passar pelo processo de civilizar-se, este vai de encontro, primeiro, com sua própria natureza, age contra suas pulsões, naquilo que Nietzsche chama de moral dos escravos. Em segundo lugar esse homem domesticado começa a criar, através de ideologias, instituições, educação, ética, um mundo que também vai de encontro com o mundo ao seu redor. O conceito de natureza que estamos usando é o "princípio de vida e de movimento de todas as coisas existentes". Esta se apresenta cheia de movimentos e pulsões que o homem moderno ignora em

${ }^{1}$ PELIZZOLI M. L., Correntes da ética ambiental. Petrópolis: Vozes 2002, p. 10.

2 MATOS, Junot Cornélio. Críticas Nietzcheanas à Modernidade. Revista Impulso, Piracicaba, v. 12, n. 28, 2001 , p. $136-7$.

3 GIACOIA JUNIOR, Oswaldo. Sonhos e pesadelos da razão esclarecida. Revista o que nos faz pensar, Rio de Janeiro, n.

18, setembro de 2004 p. $103-4$

4ABBAGNANO, Nicola. Dicionário de Filosofia. São Paulo. Martins Fontes. 2007, p. 814. 
nome de uma proposição metafísica de que o homem deveria dominar a natureza e que esta deveria servi-lo.

A crítica nietzschiana à modernidade se dá na denúncia que ele faz dos ideais da modernidade: a razão como guia da humanidade, progresso técnico-científico resolvendo todos os problemas, esperança de uma sociedade justa e livre, ideia de progresso continuo da economia, etc. A valorização destas utopias e a crença no poder de resolver as dores humanas traz um grande mal para o tipo humano. Segundo Nietzsche estes conceitos tem um lado nefasto, pois são falsos e negam a vida tornando o homem um "animal de rebanho". Ao torná-lo essa "criatura domesticada" a força que o levaria ao seu crescimento e aperfeiçoamento também é neutralizada. Para ele o mundo ocidental está se tornando niilista, ou seja, um mundo aonde todos os valores supremos vão sendo desvalorizados.

Durante o século XX o mundo ocidental sofreu com as falhas de seus projetos ideológicos na política, na economia, no trabalho, na ciência, na vida quotidiana, etc. As promessas de um mundo melhor ficaram por terra depois de duas grandes guerras, crises econômicas, sistemas políticos totalitários, epidemias, fome, desigualdade social e por fim uma crise ambiental que é vista por pesquisadores como grande ameaça à existência futura da humanidade. Ao longo do século passado as promessas nascidas na modernidade pareciam se tornar cada vez menos possíveis de serem concretizadas. Podemos perceber a importância da crítica nietzschiana a ideia de progresso dada à impossibilidade de manutenção de exploração de recursos naturais que o cenário contemporâneo expõe bem como um determinado nível de acerto dos apontamentos nietzschianos. A crise contemporânea do meio ambiente pode ser entendida como uma crise ética ou do movimento de desvalorização de todos os valores supremos (niilismo) que o mundo ocidental vive, segundo Nietzsche, logo podemos perceber a importância do pensamento deste para essa crise.

Hans Jonas parte da mudança que a técnica tem na modernidade. Se na antiguidade a técnica tinha um papel se subordinação à natureza e procurava basear-se nela em seu desenvolvimento, na era moderna a técnica aparece como uma ferramenta de domínio do homem sobre a natureza. Assim o sucesso da técnica moderna aparece como um perigo. Este perigo vem do poder de destruição da própria natureza. Surge então a questão de uma ética que consiga lidar com as novas condições do homem na terra. Jonas aponta que as morais tradicionais (aristotélica e kantiana) não levam em consideração a técnica e ao principio da responsabilidade é cabido sua superação. Diante do possível perigo dos avanços da técnica, devese assumir uma posição de responsabilidade; esta posição é levada pelo medo ${ }^{5}$. No entanto, Jonas

\footnotetext{
${ }^{5}$ LIMA, M. de. O princípio responsabilidade de Hans Jonas e a crítica de Karl-Otto Apel. Seara Filosófica, 2010.
} 
admite a transformação do medo em coragem para ser responsável pela garantia da vida no futuro.

Dado o exposto o objetivo deste trabalho é mostrar os pontos de encontro e desencontro entre o princípio da responsabilidade (Hans Jonas) e o conceito de Übermensch (Nietzsche). Pretende-se mostrar a visão de Nietzsche da relação do homem com a natureza e sua crítica. Em seguida expor os apontamentos de Hans Jonas sobre a relação do homem com a natureza e por fim apontar os caminhos e descaminhos entre os dois autores.

\section{Nietzsche e a relação do homem com a natureza.}

Partindo de um trecho do aforismo 9 da segunda dissertação da obra Genealogia da Moral de Nietzsche, podemos discutir a moral ocidental e como se deu o distanciamento do homem do mundo que o circunda, fazendo com que o sonho de criar um mundo melhor passando pela exploração da natureza se erigiu. Uma forma de tratar a natureza surgiu junto com os ideais modernos.

... pois precisamente as coisas opostas às que hoje veneramos tiveram durante muito tempo a consciência do seu lado, e Deus como seu guardião. Híbris é hoje nossa atitude para com a natureza, nossa violentação da natureza com ajuda das máquinas e da tão irrefletida inventividade dos engenheiros e técnicos; híbris é nossa atitude para com Deus, quero dizer, para com uma presumível aranha de propósito e moralidade por trás da grande tela e teia da causalidade... ${ }^{6}$ (grifo nosso)

O termo híbris é grego e designa um ato de ultraje que deve ser punido ${ }^{7}$. Essa forma de tratar a natureza vem de uma moral estabelecida por um determinado tipo psicológico. Nietzsche diz que ao determinar como o homem deveria ser, ou seja, ao tentar mudar a natureza do homem foi preciso negar o mundo. Então, foi se criando um novo mundo onde não existem paixões (os instintos são negados) ${ }^{8}$. Para melhorar o homem com essa moral, foi preciso torná-lo manso, ou seja, "castrar" seus instintos primitivos. Logo, quando esse homem tentou melhorar o mundo ao seu redor foi preciso extrair a rudeza que existe na natureza.

Essa extração pode ser entendida como violentação (ou excessiva exploração dos recursos naturais) que os avanços tecnológicos possibilitaram à civilização moderna. Isto

\footnotetext{
${ }^{6}$ NIETZSCHE, Friedrich. Genealogia da Moral. Trad. Paulo César de Souza. São Paulo: Companhia das Letras, 2009a, p. 94-5.

7 Vale reproduzir nota de Paulo César de Souza sobre o termo: “Híbris': palavra com que os antigos gregos designavam todo comportamento arbitrário, arrogante, desrespeitador dos direitos do próximo e das normas da comunidade. No sentido mais geral, aquele em que é empregada por Nietzsche, era - é - a violação das leis divinas ou naturais". A nota se encontra na página 149 de Genealogia da Moral, edição da Companhia das Letras, 2009.

${ }^{8}$ NIETZSCHE, Friedrich. Crepúsculo dos Ídolos. Trad. Paulo César de Souza. São Paulo: Companhia das Letras, 2006, p. 37.
} 
desencadeou uma crise ambiental que pode ser entendida como as previsões catastróficas de sobre a finitude dos recursos naturais e das consequências do aquecimento global para a vida de todos os animais no planeta.

Segundo Giacoia essa crise parece fazer com que o sonho moderno se torne um pesadelo ${ }^{9}$, mesmo assim abre espaço para um tema da filosofia de Nietzsche como proposta de superação do atual estado. Dado o inegável poder técnico-científico de autodeterminação cabe ao homem, e não a forças metafísicas ou científicas, a tarefa de autodeterminação. As ideias nietzschianas conduzem para a transvalorização dos valores como forma de superação do "último homem"10 que o mundo ocidental cultivou. Na Genealogia da Moral ele buscou revelar a origem de nossos valores morais e suas consequências no mundo moderno, no entanto pode-se extrair uma leitura onde a superação do homem (ou de seus valores morais) levaria à superação da crise ambiental.

Uma questão que pode ser posta como hipótese é se a genealogia da moral feita por Nietzsche aponta, entre outras coisas, os pressupostos filosóficos da relação ética do homem com a natureza que engendraram a atual crise ambiental, além de repensar esta relação em vias de apontar, seguindo o pensamento de Nietzsche, formas de superação desta ética e, logo, do problema ambiental.

É interessante salientar que o problema ambiental pode ser entendido como um problema político, logo vale observar os apontamentos de Nietzsche sobre a política. Segundo a leitura que Delbó faz sobre uma possível filosofia política em Nietzsche, pode-se entender que este faz uma crítica à política em sua época que se faz à tendência da criação de estados democráticos. A democracia seria uma herança cristã, logo levaria a moralidade cristã em seus fundamentos. Então o estado democrático faria com que os valores do tipo fraco (moral dos escravos) prevalecessem, levando adiante apenas os seres mais debilitados (ou incapacitados). Neste cenário o que Nietzsche chama de "acasos felizes" da humanidade correria risco de não existirem. Estes acasos são os tipos que tem valores mais nobres e fortes (moral dos senhores). Para Nietzsche a política deveria elaborar a cultura e melhorar a organização social visando o engrandecimento e autoelaboração da humanidade ${ }^{11}$. No entanto suas críticas se justificam pela forma como os valores são instituídos, como Delbó diz:

É porque a tarefa de instituir os valores a cada coisa ocorre a partir da perspectiva típica de um mercador e atinge as funções do estadista, dos povos e dos partidos, que Nietzsche mantém seus inúmeros ataques à política democrática. As preocupações do mercador são, para ele, nocivas para a

\footnotetext{
${ }^{9}$ GIACOIA JUNIOR, Oswaldo. Sonhos e pesadelos da rąão esclarecida. p. 103.

${ }^{10}$ Expressão utilizada no livro "Assim Falou Zaratustra" para designar o niilista.

${ }^{11}$ DELBÓ, Adriana. Nietzssche: sobre alguns problemas morais da democracia moderna. Cadernos Nietzsche, São Paulo, n. 32, maio de 2013, p. 149-154.
} 
política e para todas as outras elaborações da vida de um povo. E é por ver toda a cultura envolta por estimativas de valor reduzidas à oferta e à demanda, que os vínculos entre política e cultura na modernidade, são para, ele perniciosos. ${ }^{12}$

Neste caso o modo de valorar o mundo através de um fator econômico (oferta e demanda) seria nocivo tanto para a humanidade e para a natureza que o homem está inserido, dado que a "perspectiva de mercador" tenta mudar a natureza para que esta o sirva economicamente.

$\mathrm{Na}$ Genealogia da Moral, Nietzsche procura mostrar o desenvolvimento da história de nossa moral. Dado que a moral é um conjunto de valore que guiam a comportamento das pessoas no mundo ele entende a moral de outra forma. Para Nietzsche a moral é uma maneira de avaliar o mundo que deu origem aos conceitos de bem e mal, por exemplo, que deveriam ser seguidos. $\mathrm{O}$ filósofo faz uma reconstituição de como se deu a criação e instituição dos valores morais para o homem, ou seja, como o homem deu o cunho de "bem" e "mal" para tudo aquilo que o cerca e para o comportamento que ele pode assumir. Bem como investiga a partir de qual cenário político, social e cultural o homem criou para si esses valores. Nietzsche fez essa investigação se apoiando tanto em hipóteses como em proposições etimológicas. Toda a filosofia de Nietzsche parece girar em torno do conflito existente entre duas morais que ele chama de "moral dos senhores" e "moral dos escravos". Para ele a origem do sentido dos termos "bom" e "ruim" foi dada por aqueles que primeiro as utilizaram, ou seja, a nobreza ou aristocracia. E o termo bom os representavam e o seu modo de viver não havendo associação como a ideia de utilidade. O termo "ruim" era apenas o complemento usado por essa classe aristocrata para se distinguir daqueles que não pertenciam à mesma classe, ou seja, o homem simples, o "povo".

A partir desta origem Nietzsche explica como surgiu outra dupla de termos ("bom" e "mal") que veio a entrar em conflito com a primeira. Havia uma aristocracia que era formada tanto por uma classe política como por uma classe sacerdotal. Então houve uma transição dessa nobreza política para uma nobreza sacerdotal onde os senhores e aristocratas também eram sacerdotes. Segundo Nietzsche a partir desta transição foi o povo judeu que fez uma inversão dos valores nobres 13 . Para este povo o "mal" é o "bom" dos antigos aristocratas e o "bom" é a negação do "bom" dos aristocratas, ou seja, não ser como o tipo aristocrata. Nietzsche chama esses dois tipos de moral por várias nomenclaturas (fraco/forte, ave de rapina/ovelha, senhor/escravo, doente/sadio, moralista/imoralista, etc.), no entanto iremos adotar os termos "moral dos senhores" e "moral dos escravos". Segundo Nietzsche o surgimento dessa moral dos

12 Ibidem, p. 162.

${ }^{13}$ NIETZSCHE, Friedrich. Para Além do Bem e do Mal. Trad. Alex Marins. São Paulo: Martin Claret, 2001a, p. 110. 
escravos se dá devido a incapacidade do homem simples (escravo) se tornar forte como o tipo aristocrata (senhor). Assim essa segunda forma de valorar o mundo nasce desse tipo comum, ou escravos, que a partir de sua incapacidade de ser como os primeiros tipos (os senhores) invertem os valores daqueles criando outra dupla "bom e mal" onde esse valor negativo, "o mal", é exatamente designado pelas atitudes da moral dos senhores e o "bom" são os que não são daquele jeito, ou seja, os escravos. Esses escravos têm valores reativos, pois nascem da reação que têm ao se deparar com a outra moral ${ }^{14}$.

Segundo Nietzsche por toda a história da humanidade houve uma guerra entre essas duas morais, a mais árdua e longa guerra já travada. E saiu desta uma vencedora, mas antes vale destacar uma metáfora que Nietzsche usa para descrever como esses tipos se viam:

Que as ovelhas tenham rancor às grandes aves de rapina não surpreende: mas não é motivo para censurar às aves de rapina o fato de pegarem as ovelhinhas. E se as ovelhas dizem entre si: 'essas aves de rapina são más; e quem for o menos possível ave de rapina, e sim o seu oposto, ovelha - este não deveria ser bom?', não há o que objetar a esse modo de erigir um ideal, exceto talvez que as aves de rapina assistirão a isso com ar zombeteiro, e dirão para si mesmas: 'nós nada temos contra essas boas ovelhas, pelo contrário, nós as amamos: nada mais delicioso do que uma tenra ovelhinha'.15

O desenvolvimento desta luta milenar deu-se com a maneira como a moral dos senhores foi envenenada pela moral dos escravos e fez com que estes últimos predominassem.

[...] não é de espantar que os afetos entranhados que ardem ocultos, ódio e vingança, tirem proveito dessa crença, e no fundo não sustentem com fervor maior outra crença senão a de que o forte é livre para ser fraco, e a ave de rapina livre para ser ovelha - assim adquirem o direito de imputar à ave de rapina o fato de ser o que é... ${ }^{16}$ (grifo do autor)

A crença que ele está falando é na liberdade, pois se acreditando que se é livre para ser forte (ou fraco) e mostrando que ser forte é mal e que é melhor ser fraco se envenena a moral dos senhores. Aquela moral envenenou e transformou a "ave de rapina" em "ovelha", para usar um termo de Nietzsche, fazendo com que esta veja com misericórdia a "ovelhinha oprimida" e acredite que sua postura é uma escolha fazendo que no fim aquela se torne também uma "ovelha". Nietzsche aponta que a moral dos escravos dominou o mundo ocidental desta maneira e trouxe consequências negativas para o futuro da humanidade.

A partir do domínio desta última sobre mundo ocidental Nietzsche faz sua crítica à metafísica, ao modelo socrático-platônico, a moralidade cristã, ao antropocentrismo, a crença no poder da ciência, a ideia de progresso, a modernidade e ao homem moderno que herda todos os

\footnotetext{
${ }^{14}$ NIETZSCHE, Friedrich. Genealogia da Moral. Prólogo e primeira dissertação 2009a.

${ }^{15}$ NIETZSCHE, Friedrich. Genealogia da Moral. p.32.

16 Ibidem, p.33.
} 
aspectos desta "moral escrava". Para ele esses ideais modernos nascem do domínio da "moral dos fracos" no mundo ocidental. Pode parecer que Nietzsche está criticando todos, ele faz isso, por acreditar que todas as esferas da atividade humana estão contaminadas por essa "doença" que vem do modo de valorar o mundo voltado para a fraqueza, embora existam outras maneiras de valorar o mundo. Como ele diz:

A moral é hoje na Europa uma moral de animal de rebanho. Portanto, na nossa opinião, apenas uma espécie particular de moral humana, ao lado ou antes ou depois da qual são possíveis ou deveriam ser possíveis muitas outras morais, principalmente morais superiores. ${ }^{17}$ (grifos do autor)

Como essa moral se espalhou pelo mundo ocidental, Nietzsche percebe que há uma decadência da cultura, que o mundo está ficando niilista, que o animal homem está ficando mais pobre, que há uma negação da vida e entre todos esses "sintomas" está o homem moderno. Para ele a vida pode ser entendida como um conjunto de energias, pulsões e instintos naturais em constante luta e que a moral pode afirmar a vida, fazendo-a crescer e expandindo a capacidade de agir da humanidade, ou nega a vida, fazendo-a pequena e reduzindo a capacidade humana. Segundo Nietzsche, este homem também está "doente", e "cansado da vida"; por isso que ele nega a vida, ou seja, não consegue lidar com sua incapacidade.

Tal relação do homem com a natureza, supomos ter surgido da tradição da modernidade filosófica. $\mathrm{Na}$ modernidade surgem alguns ideais como a liberdade (livre-arbítrio), a crença no progresso capitalista trazendo riqueza para todos, a esperança de que a ciência resolveria os problemas humanos, etc. Deste último surge a ideia de dominar a natureza em proveito da vida humana criando uma relação sujeito/objeto. Com Descartes o ser humano é separado da natureza (o sujeito do objeto), o mundo é reduzido em partes para melhor se explicar a vida. Galileu percebe uma linguagem matemática na natureza e começa a fazer experimentos e descobertas sobre o funcionamento da mesma. Bacon introduz o método indutivo que pode descobrir as leis da natureza. Pode-se perceber a necessidade de dominar e controlar a natureza que os conceitos destes pensadores traziam ${ }^{18}$.

Nietzsche tem uma visão do cosmos como regido por forças plurais, e a vida nasce de uma dessas forças que se manifesta de forma orgânica. No entanto, ele aponta que existem forças ativas e forças reativas. Estas últimas teriam guiado o nascimento da moral dos fracos a partir de um olhar ressentido sobre o mundo. Nasce daí uma maneira do homem se relacionar com a natureza que implica em exploração dos recursos da natureza. É possível entender que a valorização de um mundo perfeito e a tentativa de dominar e modificar a natureza vem do

\footnotetext{
${ }^{17}$ NIETZSCHE, Friedrich. Para Além do Bem e do Mal. p. 116.

18 PELIZZOLI, M. L. Correntes da ética ambiental. p. 7-11.
} 
domínio da moral dos escravos. Com a incapacidade de lidar com o mundo como ele é estes tentariam torná-lo um lugar livre das dores e que proporcionasse conforto material para todas as pessoas. Assim uma reação é produzida da incapacidade de lidar com a natureza como ela se apresenta, criando assim um ideal de natureza que serve ao homem. Para Nietzsche estes ideais modernos são falsos e entende a modernidade "como uma época histórica cuja principal característica é a negação da vida, pela imposição de valores morais que reduzem o homem a mero animal gregário" ${ }^{\prime 19}$. Os valores morais que ele está falando fazem parte da moral dos escravos que no lugar de enriquecer o ser humano estariam empobrecendo-o.

A dominação dessa moral também é entendida como a desvalorização de todos os valores que ele chama de niilismo. Vale ressaltar o quê este termo vem a ser entendido na filosofia de Nietzsche. Segundo Deleuze o niilismo em Nietzsche tem dois significados. O primeiro é um niilismo negativo onde a vida é negada em nome de valores superiores como Deus, o bem, o verdadeiro. Neste caso o mundo é apresentado como mundo das aparências e este mundo é negado em nome do mundo-verdadeiro (o paraíso ou o mundo das ideias de Platão). O segundo é o niilismo reativo onde "o niilista nega Deus, o bem e até mesmo o verdadeiro, todas as formas do supra-verdadeiro" "20. Como Nietzsche diz no aforismo 125 de A Gaia Ciência:

'Para onde foi Deus?', gritou ele, 'já lhes direi! Nós o matamos - vocês e eu. Somos todos seus assassinos! Mas como fizemos isso? Como conseguimos beber inteiramente o mar? Quem nos deu a esponja para apagar o horizonte? Que fizemos nós, ao desatar a terra de seu sol? Para onde se move ela agora? Para onde nos movemos nós? Para longe de todos os sóis? Não caímos continuamente?21

A expressão "morte de Deus" pode ser entendida com o final da era moderna e de seus fundamentos como sugere Vattimo. Esse evento marcaria a entrada na pós-modernidade onde é revelada a insignificância dos ideais que fundaram a modernidade ${ }^{22}$. No entanto, o niilista ao negar os valores superiores e se voltar para a vida, ainda encontra uma vida negada e sem valor. Se antes a vida era negada em nome de valores suprassensíveis agora esses valores também são negados e resta ficar em um mundo cada vez mais sem valor; cada vez mais niilista. O homem reativo "coloca-se no lugar de Deus: não conhece mais valores superiores". Então outros valores surgem deste homem reativo ${ }^{23}$. Como Deleuze diz:

o homem reativo toma o lugar de Deus: a adaptação, a evolução, o progresso, a felicidade para todos, o bem da comunidade; o Homem-Deus, o homem moral,

\footnotetext{
${ }^{19}$ MATOS, Junot Cornélio. Críticas Nietz̧cheanas à Modernidade. p. 135.

${ }^{20}$ DELEUZE, Gilles. Nietzsche e a Filosofia. Trad. Ruth Joffily e Edmundo Fernandes Dias. Rio de Janeiro: Editora Rio, 1976, p. 69-70.

${ }^{21}$ NIETZSCHE, Friedrich. A gaia ciência. Trad. Paulo César de Souza. São Paulo: Companhia das Letras, 2001, p. 6465.

22 VATTIMO, Gianni. O fim da modernidade: niilismo e hermenêutica na cultura pós-moderna. Trad. Eduardo Brandão. $2^{\mathrm{a}}$ Ed. São Paulo: Martins Fontes, 2007 P. 169-174.

${ }^{23}$ DELEUZE, Gilles. Nietzsche e a Filosofia. p. 69-70.
} 
o homem verídico, o homem social. São esses os valores novos que nos são propostos em lugar dos valores superiores, são esses os personagens novos que nos são propostos em lugar de Deus ${ }^{24}$

Aquele homem (com H maiúsculo), que nega o mundo presente, está destruindo este mundo e, ao mesmo tempo, destruindo a si mesmo, para alimentar uma ideia de conforto material, ou um ideal de felicidade para todos, ou uma ideia de mundo melhor no futuro. O tipo fraco tinha que criar outro mundo onde pudesse se realizar por não ser capaz de se realizar neste mundo. Segundo Nietzsche o homem faz isto pela incapacidade de lidar com o mundo empírico que nos cerca e de lidar com os movimentos instintivos da natureza (inclusive de sua própria natureza). Pois a moral dos fracos tem que encontrar um culpado e puni-lo. Como afirma Marton:

Com Platão e o cristianismo, ocorreu a duplicação dos mundos - e passou-se a negar este em que nos achamos aqui e agora em nome de outro, essencial, imutável e eterno. Com a modernidade, procedeu-se à implosão do ser humano - e foi ele dividido em razão e paixões, intelecto e sentidos, consciência e instintos. ${ }^{25}$

Neste caso a tentativa de mudar a natureza é uma forma de dizer que há um erro no mundo e que este deve ser consertado, ou seja, esta tentativa deriva da moral dos escravos que nega este mundo em nome de outro, seja metafísico ou seja no futuro. Isso liga os apontamentos da genealogia nietzschiana a atual crise ambiental pela postura que temos diante da natureza.

Outro ponto que merece destaque é o entendimento de niilismo que Vattimo defende. Ele tenta mostrar como os conceitos de niilismo se aproximam em Heidegger e em Nietzsche. Para Heidegger o niilismo é a consumação do Ser no valor, que Vattimo entende como sendo o valor de troca. O Ser se perderia e/ou se transformaria neste tipo de valor. Pode ser coincidente com o conceito de niilismo de Nietzsche, pois este falou da desvalorização dos valores supremos, mas não dos valores "tout court" (ou seja, os valores pequenos); estes valores continuam e junto com eles o valor de troca. No que diz respeito às características da sociedade capitalista, Vattimo entende que a transformação de tudo em "valor de troca" no século XX mostra os últimos momentos de uma desumanização (consumação do nilismo) e que os esforços contra essa reificação foram ainda um niilismo reativo, pois buscava se reapropriar do sujeito e parar o domínio do objeto. Aquela experiência de mercantilização abre espaço para uma possível nova experiência humana ${ }^{26}$. Logo, podemos entender que a exploração da natureza que vem sendo praticada pelo capitalismo moderno se dá pela transformação da natureza em valor de troca, ou

\footnotetext{
24 Ibidem, p. 70.

${ }^{25}$ MARTON, Scarlett. Do dilaceramento do sujeito à plenitude dionisíaca. Cadernos Nietzsche, São Paulo, n. 25, maio de 2009 , p. 58.

${ }^{26}$ VATTIMO, Gianni. O fim da modernidade. p. 4-16.
} 
seja, se a exploração da natureza é uma negação do mundo como ele se apresenta, transformando-o em valor de troca, podemos entender isso como outra forma de niilismo.

Nietzsche estava lúcido de todos esses problemas modernos e abre espaço para a ideia de superação do homem e aponta para o Übermensch (super-homem). Para Nietzsche este homem (moderno) deve ser superado. Como ele expõe no livro "Assim Falou Zaratustra": "Exorto-vos, meus irmãos, a permanecer fiéis à terra e a não acreditar em quem vos fala de esperanças supraterrestres". E em seguida:

O homem é um rio turvo. E preciso ser um mar para, sem se toldar, receber um rio turvo. Pois bem; eu vos anuncio o Super-homem; é ele esse mar; nele se pode abismar o vosso grande menosprezo. ${ }^{27}$

Segundo Heber-Suffrin o Übermensch seria o homem de uma nova cultura e de uma nova moral que são animadas pela vontade de potência ${ }^{28}$. Em meio a estas ideias ele está mostrando a necessidade de o homem dar um novo sentido sobre a terra. Nietzsche está apontando tanto para a ideia de superação do homem e para a ideia de superação dos valores morais do homem moderno (no caso a superação da moral dos escravos); este super-homem (Übermensch) que afirma a vida pode ser entendido como seguidor e controlador de seus instintos, logo um homem sensível aos problemas do meio ambiente por aceitar e afirmar tanto seus instintos como a natureza ao seu redor. Logo, esse super-homem traria, assim, a possibilidade de superação da atual crise ambiental. Não apenas a crise ambiental, mas a consumação do niilismo também abre espaço para a superação do homem e da crise ambiental com a transvalorização dos valores.

\section{HANS JONAS E RELAÇÃO DO HOMEM COM A NATUREZA.}

Hans Jonas aponta para a necessidade de uma nova ética diante dos avanços da técnica. Para ele o poder de destruição da tecnologia exige do homem a responsabilidade de preservação da vida na terra. Assim ele enuncia o princípio da responsabilidade como um imperativo para agir "de modo que os efeitos da tua ação sejam compatíveis com a permanência de uma autêntica vida sobre a Terra". Ele entende que o homem faz parte de um todo (a natureza). O principio surge exatamente desta nova visão do homem como um ser inserido em um sistema maior e que depende deste sistema maior para continuar vivendo. Para Hans Jonas o fim da natureza é a vida, logo com o principio ficamos condenados a ser responsáveis.

\footnotetext{
${ }^{27}$ NIETZSCHE, Friedrich. Assim Falou Zaratustra. Trad. Alex Marins. São Paulo: Martin Claret, 2009b, p. 26.

${ }^{28}$ HÉBER-SUFFRIN, Pierre. O "Zaratustra” de Nietəsche. Rio de Janeiro: Jorge Zahar, 2003.
} 
Uma questão levantada sobre sua teoria é que de sentenças descritivas não se pode retirar sentenças prescritivas, seria uma falácia da natureza. Este problema se apresenta como não podendo estabelecer um valor moral a partir de um princípio determinado pela natureza. A ação moral tem que vir de uma norma e não de uma descrição. Como a natureza é apenas descritiva ela não pode determinar um principio moral. Se isto fosse possível a ação estaria sendo determinada fora do agente e assim o agente não seria livre. Então, Jonas não quer tirar a ética da ontologia, mas mostrar que a ética está contida na ontologia. Ele presa pela permanência de uma vida digna na terra ${ }^{29}$.

\section{CAMINHO E DESCAMINHOS.}

A proposta de Jonas é ampliar o campo de visão da ética, saindo de uma ética apenas humana e considerando a natureza. Assim o homem não é apenas preocupado com sua conduta, mas com os impactos da sua conduta na natureza, ou seja, responsável pela natureza em que habita. Uma solução que Jonas aponta para o problema da falácia da natureza é reafirmar que o homem pertence a natureza, mas sua moral continua centrada no homem; daí o termo "biologização do ser moral" 30. Neste ponto de considerar o homem como um ser a mais na natureza tanto Jonas como Nietzsche andam pelo mesmo caminho. A teoria das forças ${ }^{31}$ Nietzsche que chega a este entendimento.

Para além disto Jonas coloca dois argumentos contra a falacia naturalista. Primeiro que a responsabilidade é uma constatação ontológica (o ser é responsável) e segundo que o ser deve ser responsável por que o ser é (e não por que a natureza é). Para Jonas o ser "contem" a responsabilidade, então existe, (faz sentido) um "dever ser do ser" ${ }^{32}$.

Jonas fundamenta (ontologicamente) o Bem recusando os dualismos entre eles espírito e matéria. Assim como Nietzsche supera o entendimento de que o mundo é duplicado em mundo sensível e mundo racional, corpo e alma, etc. No entanto, a ideia de Bem na essência do ser não é compartilhada em Nietzsche. Não existe um bem em si que dê sentido ao mundo.

A responsabilidade vem do próprio ser. Se apresenta como um imperativo ontológico (a responsabilidade). A “sobrevivência real do ser" depende de observar o princípio da responsabilidade. A sobrevivência do ser no futuro que gera este imperativo ontológico. Jonas chega a uma imposição de cuidado (ou responsabilidade) do homem com a natureza que o

\footnotetext{
${ }^{29}$ LIMA, O princípio responsabilidade de Hans Jonas e a crítica de Karl-Otto Apel. Seara Filosófica, 2010.

${ }^{30}$ SGANZERLA, A. Biologização do ser moral em Hans Jonas. Revista de Filosofia: Aurora, v. 25, n. 36, p. 155-178, 2013.

31 Teoria de que o mundo é formado por forças plurais em constante conflito mutúo.

32 Ibidem.
} 
homem faz parte, mas partindo de uma visão um tanto metafísica. Nietzsche chegaria a um alémhomem sensível as questões de preservação da natureza, não pela metafísica, mas pelo conhecimento tanto ele quanto a natureza têm origem na mesma força e ambos tem a mesma vontade.

Jonas coloca que a liberdade é o resultado "teleológico" da natureza. Assim o homem é o ser responsável pela sua própria sobrevivência. Logo, para continuar sendo homem deve ser responsável. O princípio pede que se preserve a condição de existência da humanidade. Neste caso o homem é livre para escolher ser responsável. Dado que em seu desejo de progresso o homem coloca a existência futura em perigo. Jonas afirma que a vida é um fim que está na natureza e ao mesmo tempo um valor fundamental e a autoconservação é um fim em si mesmo para Jonas ${ }^{33}$. No entanto, a natureza não tem uma finalidade para Nietzsche, não existe uma ordenação moral no mundo que possa ser derivado para um sentido da conduta humana. As forças em conflito buscam apenas afirmar sua força (ou afirmar seu poder).

Para Nietzsche os fins são a indicação que uma vontade de poder (ou vontade de potência) dominou algo menos poderoso e inseriu uma função. Assim os fins não são dados tão pouco eternos. Assim o desenvolvimento de uma "coisa" pode ser uma sequência de novas interpretações e subjugamentos que recebe e não um progresso na direção de um fim ${ }^{34}$. No tocante as teorias evolucionistas que colocam como essência da vida a adaptação Nietzsche aponta que a essência da vida seria a vontade de potência e a adaptação apareceria apenas como uma atividade de segunda ordem. A força espontânea dessa vontade precede a "adaptação". Assim a ética da preservação - admitir que existe uma natureza e que o homem faz parte dela de Jonas se distancia na origem que levaria a uma possível harmonia na relação do homem com a natureza assim como no conceito de vida dos autores.

É necessário se perguntar se ambos os autores chegaram no mesmo lugar (conceito de homem ou conduta) por caminho nem sempre iguais? A resposta é negativa, pois o além-homem percebe que ele é parte da natureza e não tem uma finalidade, nem ele nem a natureza, mas uma constante promoção de encontros ou choques que ora são harmoniosos ora são conflituosos e em alguns casos fazem a vontade de potência se expressar (manifestar) positivamente (se expandindo) e outras vezes se manifesta negativamente (se contraindo). Não necessariamente que esta força se manifeste positivamente nos encontros harmoniosos e negativamente nos encontros conflituosos. Inclusive Nietzsche aponta para o aumento de vontade de potência no conflito ${ }^{35}$.

\footnotetext{
33 Ibidem.

${ }^{34}$ NIETZSCHE, Friedrich. Genealogia da Moral. Trad. Paulo César de Souza. São Paulo: Companhia das Letras, 2009a, p. 62.

${ }^{35}$ NIETZSCHE, Friedrich. Para Além do Bem e do Mal. São Paulo: Martin Claret, 2001ª.
} 
O sim à vida jonasiano leva a um bem em si. $\mathrm{O}$ bem em si seria um sentido novo na terra como afirma o Zaratustra? A resposta que pode ser colocada como hipótese é que o Zaratustra afirma uma atribuição de um novo sentido da terra na imanência e também no aqui/agora. Enquanto o princípio de preservar a vida que dá ao homem a responsabilidade seria uma troca da vida hoje, que está acontecendo, por uma no futuro (um futuro que nunca chega) que ameaça. Ou pelo menos, um pensar atual com a ameaça do futuro terrível como pano de fundo. Este futuro seria ainda transcendente e não imanente. Além do mais, quando Jonas aponta que devemos ter a responsabilidade de cuidar da continuidade da vida, ele está desviando do enfrentamento com a questão da finitude. Uma extrapolação desta fuga individual para a escala universal levaria a questão da finitude da humanidade. Nietzsche aponta que deveríamos dar boas vindas a morte (a finitude), mas para isto deveríamos ter consumado nossa vida em sua riqueza, ou seja, na expansão e expressão cada vez mais exuberante de uma luta e conquista por mais vontade de poder. 


\section{REFERÊNCIAS}

ABBAGnANO, N. Dicionário de Filosofia. São Paulo: Martins Fontes, 2007.

DELBÓ, A. Nietzsche: sobre alguns problemas morais da democracia moderna. Cadernos Nietzsche, v. 32, 2013.

DELEUZE, G. Nietzsche e a Filosofia. Rio de Janeiro: Editora Rio, 1976.

GIACOIA JUNIOR, O. Sonhos e pesadelos da razão esclarecida. Revista o que nos faz pensar, v. 18, 2004.

HÉBER-SUFFRIN, P. O “Zaratustra” de Nietzsche. Rio de Janeiro: Jorge Zahar, 2003.

LIMA, M. DE. O princípio responsabilidade de Hans Jonas e a crítica de Karl-Otto Apel. Seara Filosofica, 2010.

MARTON, S. Do dilaceramento do sujeito à plenitude dionisíaca. Cadernos Nietzsche, v. 25, p. 1-121, 2009.

MATOS, J. C. Críticas Nietzcheanas à Modernidade. Revista Impulso, v. 12, 2001.

NIETZSCHE, F. Para Além do Bem e do Mal. São Paulo: Martin Claret, 2001a.

NIETZSCHE, F. A gaia ciência. São Paulo: Companhia das Letras, 2001b.

NIETZSCHE, F. Crepúsculo dos Ídolos. São Paulo: Companhia das Letras, 2006.

NIETZSCHE, F. Genealogia da Moral. São Paulo: Companhia das Letras, 2009a.

NIETZSCHE, F. Assim Falou Zaratustra. São Paulo: Companhia das Letras, 2009b.

PELIZZOLI, M. L. Correntes da ética ambiental. Petrópolis: Vozes, 2002.

SGANZERLA, A. Biologização do ser moral em Hans Jonas. Revista de Filosofia: Aurora, v. 25, n. 36, p. 155-178, 2013.

VATTIMO, G. O fim da modernidade: niilismo e hermenêutica na cultura pós-moderna. São Paulo: Martins Fontes, 2007. 


\title{
TÉCNICA E NIILISMO: A URGÊNCIA DE UMA NOVA ÉTICA EM HANS JONAS ${ }^{1}$
}

Technique and nibilism: the urgency of a new ethic in Hans Jonas

\author{
José Carlos Moreira \\ Mestre em Filosofia pela \\ FAJE - Faculdade Jesuíta de \\ Filosofia e Teologia, Belo \\ Horizonte MG.
}

RESUMO: Nosso propósito aqui é em linhas gerais mostrar que do advento da técnica que se impõe na era moderna, resulta o niilismo, que por sua vez decreta: o fim da metafísica e o relativismo de valores como "ecos" de um projeto de razão, cuja promessa era em primeira instância, elevar o homem à condição de ser autônomo mediante o saber que o torna capaz de dominar a natureza. Entretanto, se por um lado, a civilização moderna celebra o triunfo da razão demonstrativa, por outro lado, esta mesma civilização, assiste concomitantemente ao abandono da metafísica e da ética, fatores estes que corroboram o niilismo e o relativismo de valores que ora vivemos. Tais fatores levam a uma incerteza em relação à continuidade da vida humana e extra-humana que agora encontra-se ameaçada pelo poder da técnica por meio da ação humana. Como alternativa a este cenário, apresentaremos a teoria da responsabilidade inaugurada por Hans Jonas como a nova ética do futuro, com os seus fundamentos metafísicos e os dois arquétipos que segundo Jonas, melhor representam sua teoria ética. Isto é, a responsabilidade do estadista e aquela dos pais em relação aos filhos. Se a técnica e o niilismo dela decorrente nos apontam para um cenário de incertezas em relação ao futuro, destacaremos essas duas formas de responsabilidades como via de superação do niilismo. Em Jonas a responsabilidade como tarefa do homem de Estado, consiste em assegurar no presente a possibilidade de que no futuro haja homens capazes de assumir responsabilidade. De igual modo, a responsabilidade dos pais em relação aos filhos trata-se de cuidar da vida. O que abri caminhos para a possibilidade de continuidade da existência de vidas no mundo de amanhã, pois o nascimento de uma criança representa o recomeço da humanidade. Sendo assim, a responsabilidade dos pais para com os filhos definirá no presente, um novo sujeito para um futuro novo.

PALAVRAS-CHAVE: Técnica; niilismo; responsabilidade.

\footnotetext{
${ }^{1}$ Parte do presente texto foi apresentado no colóquio Hans Jonas realizado na UFRJ Rio de Janeiro, entre os dias 7 e 9 de dezembro de 2016.
} 


\section{INTRODUÇÃO}

Nosso objetivo neste artigo será mostrar de que modo atécnica moderna e o niilismo relativista dela decorrente, nos impõe a urgência de uma nova ética a partir do pensamento de Hans Jonas. Para tanto, para realizarmos a tarefa a qual nos propusemos, será necessário trilharmos aqui três passos. No primeiro, mostraremos o apogeu da técnica e o niilismo relativista como "ecos" da era moderna. Sublinharemos o niilismo como a falta de sentido que emerge quando se dissolve o poder vinculante das respostas tradicionais ao por que da vida e do ser. $\mathrm{O}$ que nos resta então? Nesse caso, mostraremos que nos resta uma realidade sem diretriz. O mundo já não tem valor em si mesmo. Antes o seu valor tradicional era dado pelo homem. Contudo, com o advento da tecnologia e da biotecnologia moderna, assistimos em nossos tempos, uma indiferença em relação ao ser e o não-ser. Se por um lado, a civilização tecnológica moderna celebra o triunfo da razão demonstrativa e operacional, por outro lado, ela assiste ao exílio da metafísica o que corrobora o niilismo relativista de nossa era. Dito de outro modo, o advento da técnica moderna impõe o niilismo metafísico, e igualmente o niilismo ético como "ecos" do programa da técnica que consistia em primeira instância, na libertação do homem mediante o saber operacional capitaneado pela técnica que o torna capaz de obter total controle sobre a natureza. Contudo, explicitaremos que o que resta debaixo de nossos pés, é um solo instável e um cenário que não nos aponta nenhuma direção segura.

Frente a este cenário de incertezas que a técnica moderna nos lega, Hans Jonas constata a necessidade de uma nova ética. Jonas entende que só uma ética metafisicamente fundamentada, é capaz de se colocar como possibilidade de resgate do ser - valor, da finalidade, portanto, da metafísica. Para tanto, como alternativas ao niilismo, apresentaremos a duas possíveis vias de sua superação: a responsabilidade dos pais em relação aos filhos - parental e a responsabilidade política (coletiva). Isso nos leva a uma questão com a qual precisamos nos ocupar no percurso desta reflexão, qual seja: em que medida essas duas formas de responsabilidades podem se colocar como vias de superação do niilismo relativista o qual herdamos do apogeu que atingiu a técnica na era moderna?

Como primeira via de superação do niilismo, analisaremos a responsabilidade parental, cuja finalidade consiste em educar para tornar o filho adulto e responsável e isto representa um resgate da teleologia - valor, em tempos em que o afã tecnológico e biotecnológico, impõe o relativismo dos valores. Por isso, mostremos qual é essencialmente a tarefa da responsabilidade parental, isto é, a de preservar o bem e o valor - cuidar da vida. Nenhuma criança pede para 
nascer em qualquer que seja as situações, seja privilegiadas ou não. Porém, Jonas considera que o nascimento de uma criança representa concomitantemente o recomeço da humanidade, o que por sua vez, abri caminhos para a possibilidade de continuidade da existência de vidas no futuro longínquo. É este o "resultado" que se espera da responsabilidade enquanto dever fazer aplicada ao âmbito parental - a continuidade da existência humana no mundo. Esta, portanto trata-se da primeira resposta ética, a qual exige a técnica e o niilismo relativista de nossos tempos.

Finalmente, no ultimo passo de nosso artigo, destacaremos a responsabilidade política (coletiva) como resposta ética e segunda via de superação do niilismo. Mostraremos que a preocupação de Jonas com a continuidade da humanidade e da responsabilidade além da esfera parental se estende também ao âmbito político, por isso mesmo, ele propõe a responsabilidade política como segundo modelo paradigmático para pensar a ética. Eis a nossa tarefa nesse artigo, e já que anunciamos o que faremos, agora é ora de realizarmos o que prometemos. Passaremos, portanto, ao primeiro ponto deste trabalho.

\section{1- O APOGEU DA TÉCNICA E O NIILISMO RELATIVISTA: "ECOS” DA ERA MODERNA}

A técnica moderna é dominada por aquilo que Martin Heidegger caracterizou como o desabrigar que em nossos tempos se mostra como um desafio - o niilismo o qual se hospeda na casa humana como Nietzsche assim dizia, causando a diluição de nossas diretrizes, nos impondo uma realidade obscura - a crise. A era moderna não oferece nenhuma direção, sentido ou valor ao homem. Sendo assim, ela expressa o seu mais intenso niilismo. É isso o que faz com que, segundo Jonas, o "niilismo moderno seja infinitamente mais radical e desesperado do que o niilismo gnóstico" (RG, p. 349, apud, OLIVEIRA, J. 2014. p. 125). O niilismo se mostrou como o resultado de um mundo sem Deus, e isto decretou o fim dos valores tradicionais e transcendentes. Já que os valores supremos se depreciaram, agora, a era moderna padece pela falta de finalidade. O niilismo, nas palavras de Franco Volpi é "pois, a "falta de sentido" que desponta quando desaparece o poder vinculante das respostas tradicionais ao porquê da vida e do ser" (VOLPI, F.1999, p. 55). Resta-nos então uma realidade sem diretriz. O mundo - natureza não tem valor em si mesmo, antes sendo o seu valor tradicional, "dado pelo homem - que por fim se tornará ele próprio um ser do qual não se pode dizer que seja também um fim em si, como bem o tem atestado a tecnologia e a biotecnologia moderna e isso leva a uma indiferença em relação ao ser e o não-ser.” (LOPES, W. 2008. p.32). 
Se por um lado, a civilização tecnológica moderna celebra o triunfo da razão demonstrativa e operacional, por outro lado, ela assiste ao exílio da metafísica o que corrobora o niilismo relativista de nossa era. Dito de outro modo, o advento da técnica moderna impõe o niilismo metafísico, e igualmente o niilismo ético como "ecos" do programa daquela, cuja promessa consistia em primeira instância, na emancipação do homem mediante o saber operacional capitaneado pela técnica que o torna capaz de obter total controle sobre a natureza. Entretanto, tal programa com o seu poder de ação, mostra sua face obscura, a qual torna-se um risco para o próprio homem, pois o progresso científico-tecnológico, transformou-se naquilo que Jonas chamou de "Prometeu definitivamente desacorrentado" (PR. 2006, p. 21)2. Tal constatação, no entanto, coloca em dúvida, as condições globais da vida humana, o futuro da espécie e da natureza como um todo.

Como se vê, a já “enorme capacidade de ação decorrente do saber científico e tecnológico não cessa de aumentar, com sempre menos regras capazes de exercer um efetivo controle" (NEDEL, J. 2006, p. 146). Produziu-se, com o poder desmedido conferido à razão, um profundo “vácuo ético" (PR. p. 21) que também é “o vácuo do relativismo de valores atual” (Ibidem, p. 21). Com o ruir das grandes narrativas e a negação da fé na Revelação, e na validade de seus princípios, "afirmou-se a ciência como única fonte de verdade, com o que se perderam os fundamentos dos quais teria sido possível deduzir normas éticas para regular o progresso tecnológico” (NEDEL, J. 2006, pp. 146-147). Agora, nas palavras de Jonas,

Trememos na nudez de um niilismo no qual o maior dos poderes se une ao maior dos vazios; a maior das capacidades, ao menor dos saberes sobre para que utilizar tal capacidade. Trata-se de saber se, sem restabelecer a categoria do sagrado, de cabo a rabo pelo Aufkelärung (Iluminismo) científico, é possível ter uma ética que possa controlar os poderes extremos que hoje possuímos e que nos vemos obrigados a seguir conquistando e exercendo. (PR. 2006, p. 21.).

Ao alcançar seu apogeu, a técnica moderna impõe o niilismo. Com isso, como bem observa Franco Volpi, a situação do homem contemporâneo é de incerteza e precariedade. Pois, "lembra a de um andarilho que há muito caminha numa área congelada e, de repente, com o degelo, se vê surpreendido pelo chão que começa a se partir em mil pedaços. Rompidos a estabilidade dos valores e os conceitos tradicionais, torna-se difícil prosseguir o caminho" (VOLPI, F. 1999, p. 7). O niilismo, continua o autor, constitui uma situação de "desnorteamento provocado pela falta de referências tradicionais, ou seja, dos valores e ideais que representavam

\footnotetext{
${ }^{2}$ Como esta trata-se da obra magna de Jonas a qual constitui a chave mestra para a nossa reflexão, na sequência deste artigo, a citaremos sempre com as iniciais PR. Outras obras de Jonas e demais autores, citaremos de acordo com a formula autor data.
} 
uma resposta aos porquês e, como tais, iluminavam a caminhada humana" (Ibid.1999, p. 8). Vêse, pois, que sem a referência dos valores tradicionais, o niilismo emerge como a face 'escura' de uma era cujo arcabouço técnico, nos revela como já vimoso vazio de sentido que se mostra quando sucumbi o poder e o valor vinculante das respostas tradicionais ao porquê da vida e do ser. Isto

É o que ocorre ao longo do processo histórico no decorrer do qual os supremos valores tradicionais que ofereciam resposta aquele "para quê?" Deus, a verdade, o bem - perdem seu valor e perecem, gerando a condição de "ausência de sentido" em que se encontra a humanidade na sociedade contemporânea (Ibid, p. 57).

A modernidade conferiu primazia à técnica objetivando o homem e o seu bem viver, no entanto, o que resulta da técnica é justamente o vazio de sentido que emerge da dilaceração do ser e dos valores vinculantes. Destarte, o homem permanece um enigma para a ciência e a técnica moderna as quais são incapazes de fornecer sentido à existência humana. (Cf. OLIVEIRA, C. 2013. p. 51). A técnica não é capaz de conferir o sentido do viver para o homem moderno, pois ao desafiar e exilar a metafísica, ela impõe o que Martin Heidegger, chamou de "esquecimento do ser."

Frente ao niilismo metafísico e igualmente o niilismo ético que resultam da face obscura do progresso tecnológico moderno, Hans Jonas constata a necessidade de formulação de uma nova ética para orientar o nosso agir no cenário instável no qual estamos. Segundo o filósofo, é indispensável controlar a "caixa de Pandora do conhecimento científico que abrimos..., fazer uma pausa e pensar realmente onde estamos, para então decidir, com a ajuda da sabedoria, em que direção se deve continuar.” (JONAS, H. 1997, p. 202.)

Sendo assim, diante da ambivalência da técnica, que regula o nosso viver atual, o projeto filosófico de Jonas emerge na contemporaneidade como um referencial no âmbito da ética capaz de lançar luzes sobre o vazio metafísico, ético e a escuridão que ora enfrentamos. A promessa de liberdade da racionalidade tecnocientífica reverteu-se em ameaça e isso nos leva a uma incerteza em relação à continuidade das condições globais de existência. Nesse caso, Jonas entende que

A ética é chamada a responder mesmo metafisicamente às questões do dia, pois, não podemos assistir ao crepúsculo da metafísica. (...). Assistir a chegada de uma tal paisagem sombria. Para "longe de todos os Sóis" é onde tem nos levado a empresa tecnológica de nossa atual civilização. Assim, nos vemos diante de um destino sombrio, onde se nos obrigam a conviver (...) Há que se perceber que a tecnologia, portanto, reclama à ética uma mirada metafísica não só por seu poder meta-físico, e por tornar a própria essência humana objeto de 
sua ação, mas também, e antes de tudo, o seu poder é meta-físico porque nega o próprio âmbito do que é metafísico, o valor do Ser como um todo: a crise que a tecnologia abre, em última instância, é a da questão do valor de tudo aquilo que é objeto de sua ação - aí incluído o homem, a natureza, enfim: o todo do Ser. E é essa crise mais profunda - a crise do valor - que está relacionada com o niilismo. A tecnologia, portanto, se encontra às voltas com o niilismo. (LOPES, W. 2008, p. 29).

Vê-se, pois, que a nossa era moderna se depara com a falta de finalidade. É isto que herdamos após o ruir das grandes narrativas as quais se colocavam como valores vinculantes. Já que a tecnologia e o niilismo relativista dela decorrente fincam raízes no solo da modernidade, agora o que assistimos é, portanto, o relativismo dos valores. Eis, portanto, o cenário, ele, porém, não nos apontam sinais de horizontes claros, ao contrário, todos os sinais que vemos ecoam sons de incertezas. Nesse caso, qual é a saída? Uma possibilidade seria o resgate da teleologia - o bem e o valor. Para tanto, Jonas constata a necessidade da formulação de um novo princípio éticoque seja capaz de afrontar os ecos da era moderna. Com efeito, Jonas entende que uma nova ética para a civilização tecnológica, deve levar a marca de uma ética da responsabilidade e, considerando o sentido da responsabilidade como um dever ontológico, Jonas apresenta dois arquétipos que segundo ele são os que melhor exemplificam sua teoria ética, isto é, a responsabilidade parental e a responsabilidade política. Se de um lado, o afã científico e tecnológico leva ao exilio da metafísica e da ética, de outro, os dois arquétipos destacados pelo filósofo podem ser vias de superação do niilismo relativista de nossos temos, dado que os dois representam o bem e o valor e nesse caso, assegurar o bem e valor, são formas de refutar o niilismo e resgatar a metafísica. Isso nos leva ao segundo ponto no qual destacaremos a responsabilidade parental como uma primeira via possível de superação do niilismo relativista que resulta do apogeu da técnica na era moderna.

\section{2 - A RESPONSABILIDADE PARENTAL: PRIMEIRA VIA DE SUPERAÇÃO DO NIILISMO E DO RELATIVISMO?}

A empresa ética de Jonas toma o futuro como o seu objeto. A preocupação do autor consiste em assegurar indeterminadamente a continuidade da vida humana e suas condições de existência no futuro. A responsabilidade dos pais em relação aos filhos trata-se de cuidar o servida. Embora nenhuma criança peça para nascer em qualquer que seja as situações, sejam privilegiadas ou não, Jonas considera que o nascimento de uma criança representa o recomeço da humanidade, o que por sua vez, abri caminhos para a possibilidade de continuidade da existência de vidas no mundo de amanhã. Sendo assim, a responsabilidade dos pais para com os filhos 
definirá no presente, um novo sujeito para um futuro novo. Isso exige, entretanto, que o dever se manifeste efetivamente, pois sendo a responsabilidade um dever ontológico contido no ser, ele é reivindicado no dever ser dos pais, cuja responsabilidade reverbera como um dever em relação ao recém-nascido. Neste caso o ser - vida reivindica existência, mas a resposta que emana dessa forma de 'poder', não resulta da mera reciprocidade, mas da responsabilidade assimétrica, cuja finalidade se realiza numa via de mão única.

A partir da analogia estabelecida com o recém-nascido Jonas mostra a aplicação da teoria da responsabilidade. Mas o que o filósofo pretende com tal analogia? A pretensão do autor é a de pensar um modo efetivo de assegurar a continuidade da existência de uma humanidade futura. Porém, isso implica um dever, cujo modo de expressá-lo se dá em duas formas: em primeiro plano, para com a existência de uma humanidade futura, independentemente se os nossos descendentes diretos façam parte, e igualmente um dever em relação ao seu modo de ser, isto é, preservar a sua condição (Cf.PR. 2006, p. 90). Em Jonas, o cuidado com o recém-nascido figura como um exemplo que corresponde tanto ao dever objetivo, quanto ao querer subjetivo, em outros termos, a responsabilidade objetiva e seu sentimento subjetivo (Cf. SGANZERLA, A. 2012, p. 212). Desse modo, estaria superada a suposta distância entre ser e dever, porque na constituição do próprio ser, está presente um dever elementar que é concedido pela própria natureza. Com isso, é em relação ao recém-nascido "que o sentimento de responsabilidade apresenta sua força, e convida a responsabilizar-se, constituindo assim a coincidência entre o aspecto subjetivo e objetivo da responsabilidade ética" (Ibidem. p. 212). De acordo com Jonas, responsabilizar-se pelo recém-nascido é também comprometer-se com o todo da humanidade, pois a "esperançosa ideia" de um constante recomeço da humanidade ${ }^{3}$, está atrelado à criança recém-nascida.

A responsabilidade pensada além da ação já realizada, a exemplo do direito civil e penal, representa em Jonas, a busca por um sentido que possa garantir o direito à existência, de modo autêntico, daqueles que ainda não existem. O futuro da teoria da responsabilidade proposta por Jonas é nas palavras de Ricoeur, totalmente antagônico, pois é ainda o futuro dos homens “(...) que agem e que sofrem, mas sob a condição da sobrevivência da humanidade; o novo princípio, portanto, visa apenas ao agir da humanidade futura através de seu viver e de sua sobrevivência." (RICOEUR, P. p. 229, 1996). Com efeito, a sobrevivência da humanidade futura tal como

\footnotetext{
3“Ao olhar o exemplo do recém-nascido Sève aponta que este não pode ser usado como arquétipo porque ele representa o presente, o que faz com que ele se impunha como uma prescrição afirmativa, isto é, como alguém que precisa ser nutrido, cuidado. (1990, p. 86). A esse respeito a posição de Speamann é ainda mais radical, pois afirma que a responsabilidade paterna "não se fundamenta nem sobre um princípio, nem sobre uma máxima, mas sim sobre uma percepção" (1996, p. 283). Ou seja, existe uma exigência à autoconsevação, na medida em que o corpo do ser humano necessita dos outros para a sua sobrevivência". Inserimos aqui a análise já antecipada porSGANZERLA, Anor. Ibidem. 2012, p. 212.
} 
entende Jonas, está condicionada ao novo imperativo ético, cuja orientação consiste em repensar o poder da ação humana no presente, de modo a assegurar o direito de ser no futuro daqueles que não existem.

Os argumentos da ética tradicional de que o direito a reivindicação pertence apenas aquele que existe, tornaram-se insuficientes para a ética do futuro postulada por Jonas. "A tese de que toda vida por si mesma reivindica continuar a viver não pode ser ignorada pela ética, pois mesmo que o ainda não vivente não faça reivindicações, nem por isso pode ter seus direitos negados." (SGANZERLA, A. 2012, p. 212.) Ao lidar com o não existente, a responsabilidade “tem de ser independente tanto da ideia de um direito quanto da ideia de uma reciprocidade, de tal modo que não caiba fazer-se a pergunta brincalhona, inventada em virtude daquela ética: 'o que o futuro já fez por mim? Será que ele respeita os meus direitos?” (PR. p. 89).

O recém-nascido, o qual Jonas usa como arquétipo, coloca em evidência a seguinte situação: mesmo na ausência de reciprocidade, ou na disparidade entre os envolvidos, a criança se torna um sujeito de direitos, embora não possa exercê-los sem a assistência de seus progenitores, e se os seus direitos são exercidos pelos pais, de igual modo são também seus deveres, pois o recém-nascido com sua fragilidade natural não pode cumpri-los. (Cf. COMÍN, 2005, p. 25.) De onde se segue que na elaboração filosófica jonasiana, urge desconstruir o dogma da tradição, de que apenas aquele que existe pode reivindicar direitos. Se o discurso filosófico da tradição construiu o dogma do "não direito dos não nascidos". O principio responsabilidade de Jonas contrapõe àquele da tradição, pois ele visa assegurar o direito à vida daqueles que ainda não nasceram. A responsabilidade dos pais em relação aos filhos corrobora esse direito no futuro. $\mathrm{E}$ a necessária desconstrução do antigo princípio da tradição se impõe, sobretudo em razão da técnica moderna, cujo uso excessivo ameaça à continuidade da vida no futuro. Com isso, o direito de existir deve ser assegurado. Neste caso, a garantia de que no mundo de amanhã existam homens de direito, capazes de decidir, deve ser assegurada por nós no hoje da história, e a teoria da responsabilidade postulada por Jonas a isso se propõe.

A responsabilidade aplicada à relação dos pais para com os filhos é usada por Jonas na elaboração de sua teoria ética como arquétipo da responsabilidade. Desse modo, ela é ao mesmo tempo condição de possibilidade "da articulação entre ser e dever ser e entre ontologia e ética." (JONAS, H. Memorias. 2005. p. 350). O recém-nascido em seu simples ato de respirar dirige aos seus responsáveis um dever irrefutável, pois "na insuficiência radical do recém-nascido está previsto ontologicamente que seus pais o protejam contra sua queda no nada e que se encarreguem de seu devir futuro" (PR. p. 224). Tal exigência implica cuidar da sua existência, independente da compaixão, da misericórdia ou de qualquer outro sentimento. Para Jonas "a 
simples existência de um ser ôntico contém intrinsecamente, e de forma evidente, um dever para outros.” (PR. p. 220) A relação entre pais e filhos usada por Jonas como arquétipo da teoria da responsabilidade que ele postula,

implica um "dever" - em primeiro lugar, um "dever ser" de algo [alguém - a criança], e, em seguida, um "dever fazer" de alguém como resposta àquele dever ser. Ou seja, em primeiro lugar, encontra-se o direito intrínseco do objeto. Somente uma reivindicação imanente ao Ser pode fundamentar objetivamente o dever de uma causalidade do Ser transitivo. A objetividade precisa realmente vir do objeto. (Ibid. p. 219).

Como se observa essa exigência imanente do ser é o próprio ser, ser-dever, ou em outros termos, o direito natural de continuar existindo. Quando a vida do ser, isto é, o recém-nascido exige ser protegida em razão de sua evidente fragilidade, "o imperativo de seguir existindo converte-se em um apelo à responsabilidade de quem tem o poder. Ou seja, a chamada à responsabilidade para o dever ser converte-se em dever, o dever de fazer o todo possível para que se cumpra o imperativo." (SGANZERLA, A. 2012, p. 215.). Nisto se realiza a teoria ética de Jonas aplicada ao âmbito parental. Em tal âmbito, a exigência de responsabilidade para com o recém-nascido urge, e isso sinaliza uma perspectiva de superação do vácuo ético contemporâneo. Se para Jonas, "com cada criança que nasce recomeça a humanidade" (PR. p. 224) podemos, portanto, concluir que com o recém-nascido estará também assegurada a sobrevivência da humanidade no mundo de amanhã. Esta seria uma possibilidade de saída do niilismo metafísico e ético que herdamos do advento da técnica moderna. Entretanto, além deste arquétipo do recémnascido como possibilidade de resgate da finalidade - valor, portanto, da metafísica, a responsabilidade política emerge também como uma segunda via possível de superação dos 'ecos' assombrosos da era moderna: a técnica e o niilismo relativista. Eis a tarefa com a qual nos ocuparemos no terceiro ponto do nosso artigo.

\section{3 - A RESPONSABILIDAdE POLÍtICA: SEGUNDA VIA DE SUPERAÇÃO DO NIILISMO?}

Como vimos na ética do futuro postulada por Jonas, a relação dos pais para com os filhos emerge como arquétipo primordial da responsabilidade. De onde se segue que tal responsabilidade abre a possibilidade de continuidade da sobrevivência humana no futuro. Isso posto, essa forma de responsabilidade se estabelece como orientação e superação da realidade niilista em que vivemos. O dever dos pais para com o recém-nascido aponta a construção do futuro, mas em Jonas, a construção do futuro é um desafio que se impõe também ao homem público, cuja responsabilidade é em primeira instância livremente escolhida, de modo a 
ambicionar o poder em larga escala com vistas ao exercício da responsabilidade em um nível mais amplo. A responsabilidade política consiste na ampliação do raio de atuação do agente - o homem político. Mas a que se deve a necessidade de tal ampliação? A responsabilidade política é devedora da ideia de que esta ampliação está intimamente ligada à dimensão histórica, isto é, a preocupação fundamental neste momento está voltada ao futuro, pois implica a continuidade de uma identidade a qual também integra a responsabilidade coletiva, sendo esta, resultada daquela responsabilidade suprema exercida pelo homem político.

Se a sobrevivência da humanidade no futuro está condicionada à responsabilidade livremente assumida do homem político, como é o caso da responsabilidade parental, precisamos também destacar que ambas são correlatos do poder. Mas nas palavras de Jonas "é, sobretudo, o verdadeiro homo politicus quem ambiciona a responsabilidade ligada ao poder e tornada possível graças a ele, e que por isso ambiciona ambos ao mesmo tempo.” (PR.p.172). Segue-se daí que para o homem político, ambicionar o poder tem em vista assumir e realizar a responsabilidade em relação aos outros, sobretudo, para com aqueles que ainda não existem.

Assim sendo, como Jonas nos diz, "O homem público autentico estimará como sua glória (que pode lhe ser muito cara) precisamente que possa dizer dele que fez o melhor que pôde por aqueles sobre os quais detinha poder, ou seja, para aqueles em virtude de quem ele tinha poder." (Ibidem. p. 172). Portanto, em Jonas o poder emerge como fundamento da responsabilidade, mas não enquanto sobreposição. Em outros termos, trata-se do poder para e não do poder sobre. Desse modo, este último assumi o sentido de responsabilidade, cujo objetivo "é a res publica, a coisa pública, que em uma república é potencialmente a coisa de todos, mas realmente só o é nos limites do cumprimento dos deveres gerais da cidadania." (Ibidem. p. 172) Isso aponta para a necessidade do exercício da cidadania como condição para a efetivação da responsabilidade coletiva, que como dizíamos, integra também a responsabilidade política, cujo objetivo é justamente o de assegurar a sobrevivência de todos.

Daí se pode vislumbrar de fato a possibilidade de construção e efetivação do futuro como garantia de continuidade da espécie humana, tempo para o qual destina-se a elaboração ética de Jonas. E já que o futuro se estabelece como a ideia mestra que conduz o empreendimento ético jonasiano, logo, ele precisa ser preservado do perigo que hodiernamente representa o uso desmedido que se faz da técnica moderna. Por isso mesmo, nas palavras de Jonas, "o perigo que ameaça a comunidade em paralelo à convicção de que ele sabe o caminho para a salvação (e pode conduzi-la) torna-se um forte incentivo para que o homem corajoso se candidate e assuma a responsabilidade." (Ibidem, p. 172). Vê-se, pois, que paradoxalmente, o perigo que a técnica representa torna-se a mola propulsora para a responsabilidade, pois, a ameaça de catástrofe que 
resulta do afã do progresso utópico da técnica moderna nos conduz àquilo de Jonas chama de heurística do temor, que por sua vez faz com que seja despertado em nós o dever de prudência. Ou seja, "a mais sublime liberdade do eu conduz ao mais exigente e inclemente dos deveres." (Ibid, p.173). A partir disso emerge a urgência de responsabilidade, que por sua vez apela ao homem político para que este entre em cena e realize o que dele se espera, isto é, assumir num sentido amplo a responsabilidade no presente, com vistas à construção do futuro mediante o qual seja possível a continuidade da existência humana no mundo de amanhã.

A responsabilidade do homem político, consiste em tornar possível a vida coletiva no estado. Numa referência à posição aristotélica, Jonas afirma que

\begin{abstract}
o estado surge para tornar possível a vida humana e continua a existir para que a vida boa seja possível. Essas são também as preocupações do verdadeiro homem público. [...] O "homem público", no pleno sentido da palavra, ao longo da duração de seu mandato ou poder, assume a responsabilidade pela totalidade da vida da comunidade, por aquilo que costumamos chamar de bem público. (Ibid., p.180).
\end{abstract}

Nessa passagem, observa-se que a responsabilidade pela totalidade da vida assumida pelo homem público advém do seu poder como o correlato do seu agir responsável. Em outros termos, a responsabilidade está condicionada ao poder. Para o homem político diz Jonas, a conquista do poder deve visar objetivamente a responsabilidade. E "a dimensão dessa responsabilidade se assemelha à da responsabilidade parental: ela se estende da existência física aos mais elevados interesses, da segurança à plenitude, da boa condução até a felicidade." (Ibid., p.180). De onde se conclui que nesses dois âmbitos, com acento para o modelo parental, a responsabilidade neles empregadas constitui os arquétipos primordiais de toda responsabilidade, justamente porque elas visam o sujeito, num movimento que se inicia desde o Ser ao poder ser ${ }^{4}$ tanto no presente quanto, na continuidade do poder ser nos tempos vindouros.

Neste caso o ser e o poder ser do objeto, desperta o sentimento de responsabilidade dos pais em relação aos filhos, como também do homem público. Nas palavras de Jonas, "o homem público não é genitor da coletividade, cuja responsabilidade ele pretende assumir; ao contrário, é o fato de que ela já existe que lhe permite assumir tal responsabilidade e buscar o poder necessário para fazê-lo.” (Ibid., p.182). O poder é a mola propulsora da responsabilidade do homem público. Em outras palavras, a ação responsável do homem de estado está condicionada

\footnotetext{
$4 \mathrm{Ou}$ seja, tanto a responsabilidade estatal quanto a responsabilidade parental, além de visarem à existência da humanidade, asseguram as condições mediante as quais a humanidade continuará existindo. E isso não significa determinismo. Pois em Jonas esses arquétipos emergem como formas de assegurar o Ser, sendo que neste ser está contida a exigência de continuidade. Em outros termos, não basta somente assegurar o ser e permitir que, em termos futuros, ele seja apenas um ser em potencial. Como vimos, é necessário que seja garantida a vida do ser e concomitantemente o seu poder ser no futuro.
} 
ao seu poder, ambicionado numa escala mais ampla, de modo a assumir a responsabilidade também em escala mais ampla. O poder ambicionado pelo homem político impõe a exigência do fazer, isto é, a responsabilidade em ato, para que por meio dela, seja potencializada a responsabilidade de outros.

Assim sendo, a finalidade do poder que resulta na responsabilidade do homem político trata-se de corroborar o poder ser dos já existentes e também construir o futuro, com vistas à continuidade do poder ser das futuras gerações. E estando assegurada a continuidade destas, Jonas entende que a responsabilidade estaria assegurada no futuro, uma vez que o objetivo do projeto ético jonasiano é justamente garantir a possibilidade de que haja responsabilidade.

Ora, tal empreendimento se impõe como tarefa ao homem público, cuja arte de governar é, nas palavras de Jonas, “responsável por toda arte de governar no futuro”, (Ibid., p.201), ou dito de outra forma, uma das responsabilidades assumida pelo homem público - continua o filósofo, "é garantir que a arte de governar continue possível no futuro. [...] Aqui, o princípio é o de que toda responsabilidade integral, com seu conjunto de tarefas particulares, é responsável não apenas por cumprir-se, mas por garantir a possibilidade do agir responsável no futuro" (Ibidem., p.201). Portanto, como se pode observar, a continuidade da vida humana no futuro torna-se objeto da elaboração da empresa ética jonasiana. Por isso mesmo, o autor utiliza como arquétipos da responsabilidade que ele quer inaugurar, as responsabilidades: paterna e política. Elas abrirão o horizonte do futuro possibilitando então, a continuidade da espécie humana e com ela a continuidade da própria responsabilidade.

Em suma, ao homem político cabe realizar o que dele se espera, isto é, assumir num sentido amplo a responsabilidade no presente, com vistas à construção do futuro, de modo a assegurar a continuidade da espécie humana no mundo. Isso posto, podemos então concluir que sendo a tarefa do homem político a de cuidar da vida de forma ampla, esta, e igualmente aquela dos pais em relação aos filhos podem, portanto, se estabelecer tal como entende Jonas como os novos 'ecos', em substituição àqueles do niilismo relativista que tantas incertezas nos trazem.

\section{CONSIDERAÇÕES FINAIS}

Chegamos ao final de nossa reflexão e nela procuramos mostrar de que modo a técnica moderna e o niilismo que dela resulta, exige uma ética. Nossa exposição girou em torno de três pontos. No primeiro, mostramos o apogeu da técnica e o niilismo relativista como "ecos" da era moderna. Destacamos o niilismo como a falta de sentido que se insurge com o ruir dos valores transcendentes e convencionais. Neste caso, o que nos resta? Mostramos que, resta-nos uma 
realidade sem diretriz. O mundo não tem valor em si mesmo, antes sendo o seu valor tradicional, dado pelo homem - que por fim se tornará ele próprio um ser do qual não se pode dizer que seja também um fim em si, como bem o tem atestado a tecnologia e a biotecnologia moderna e isso leva a uma indiferença em relação ao ser e o não ser.

Destacamos que, se por um lado, a civilização tecnológica moderna celebra o triunfo da razão demonstrativa e operacional, por outro lado, ela assiste ao exílio da metafísica o que corrobora o niilismo relativista de nossos tempos. Dito de outro modo, o advento da técnica moderna impõe o niilismo metafísico e ético, como ecos do programa da técnica. Explicitamos que o que nos resta agora, é justamente um solo instável e um cenário que não nos aponta direções claras.

Ora, diante deste cenário de incertezas que a técnica moderna nos lega, sublinhamos que no pensamento de Hans Jonas, uma nova ética urge. Em Jonas, só uma ética metafisicamente fundamentada, é capaz de se colocar como possibilidade de resgate do ser - valor, portanto da metafísica. Entretanto, como alternativas ao niilismo, apresentamos as duas possíveis vias capazes de superá-lo: a responsabilidade dos pais em relação aos filhos - parental e a responsabilidade política (coletiva).

Como primeira via de superação do niilismo, analisamos a responsabilidade parental, cuja finalidade consiste em educar para tornar o filho adulto e responsável e isto representa um resgate da teleologia - valor, em tempos nos quais o afã tecnológico e biotecnológico, impõe o relativismo dos valores. Por isso, mostramos que a tarefa da responsabilidade parental é a de preservar o bem e o valor - cuidar da vida.

Nenhuma criança pede para nascer em qualquer que seja as situações, seja privilegiadas ou não. Porém, Jonas entende que o nascimento de uma criança representa o recomeço da humanidade, e isso abri a possibilidade de continuidade da existência de seres responsáveis no futuro longínquo. Eis o que se espera da responsabilidade enquanto dever fazer aplicada ao âmbito parental. Esta, portanto trata-se da primeira resposta ética, a qual exige a técnica e o niilismo relativista dos novos tempos.

Por ultimo, destacamos no último ponto de nossa reflexão, a responsabilidade estatal como resposta ética e segunda via de superação do niilismo. Mostramos que a preocupação de Jonas com a continuidade da humanidade e da responsabilidade além da esfera parental, se estende também ao âmbito político, por isso mesmo, vimos que ele propõe a responsabilidade política como segundo modelo paradigmático, a partir do qual torna-se possível pensar a ética e com isso reconduzir ao caminho de busca pela teleologia. 


\section{REFERÊNCIAS}

ARALDI, Clademir. O niilismo como doença da vontade humana. IHU On-Line. Revista do Instituto Humanistas Unisinos, São Leopoldo, 20 de dezembro de 2010 Edição 354.

COMÍN, G. Introdução. In: JONAS, H. Poder o impotencia de la subjetividad. Tardução de Illana Giner Comín. Coleção Pensamento Contemporâneo. Barcelona/Buenos Aires/México: Paidós, 2005.

HUXLEY, Alduos. O Admirável mundo novo. Lisboa, Portugal, Ed. Antígona, 2013, p. 307.

JONAS, Hans. O Princípio Responsabilidade: ensaio de uma ética para uma civilização tecnológica. Rio de Janeiro: Contraponto, PUC Rio, 2006.

—. Técnica, medicina e ética: sobre a prática do princípio responsabilidade. Trad. Grupo de trabalho Hans Jonas da ANPOF. São Paulo, Paulus, 2013.

. Memorias. Madrid: Editorial Losada, 2005.

LIMA VAZ, Claudio Henrique. Escritos de filosofia VII: Raízes da Modernidade. São Paulo, Loyola, 2002.

. Ética e razão moderna. Síntese, n. 68 (1995) 53-84.

LOPES, Wendell Evangelista Soares. A fundamentação metafísica do princípio responsabilidade em Hans Jonas. Belo Horizonte: Faculdade Jesuíta de Filosofia e Teologia, 2008.

NEDEL, José. Ética da Responsabilidade segundo Hans Jonas. In: Ética Aplicada. São Leopoldo: Unisinos. 2006, p. 146-147.

OLIVEIRA, Jelson. A interpretação analógica das relações entre niilismo gnóstico e niilismo existencialista segundo Hans Jonas. Síntese, Belo Horizonte, v. 41, n. 129, 2014.

POSSENTI, Vittorio. Nichilismo e Metafísica: Terza Navigazione. Roma, Armando, 1998.

RICOEUR, Paul. Ética e Filosofia da Biologia em Hans Jonas. In: Leituras 2: A região dos filósofos. SP: Edições Loyola, 1996, p. 229-244 [p. 229]. 
VATTIMO, Gianni. Morte de Deus e fim da metafísica: a luta contra os absolutos. $I H U$

On-Line. Revista do Instituto Humanistas Unisinos São Leopoldo, 20 de dezembro de 2010 Edição 354.

VOLPI, Franco. O Niilismo. São Paulo, Edições Loyola. Trad. Aldo Vannucchi, 1999. 


\section{MATÉRIA E ESPÍRITO NA COSMOLOGIA JONASIANA}

Matter and spirit in Jonasian cosmology

\section{Lilian S. Godoy Fonseca UFVJM-NEPC/UFMG}

RESUMO: A abrangência temática dos escritos jonasianos é tão surpreendente quanto a profundidade com que os temas são neles abordados. Um bom exemplo dessa afirmação pode ser encontrado num opúsculo intitulado Materie, Geist und Shöpfung, brilhantemente traduzido para o português, Matéria, Espirito e Criação, pelo nosso colega Wendell Lopes. A modesta dimensão da obra quase encobre a densidade filosófica dos artigos ali reunidos. No Prefácio, o próprio Jonas esclarece que a motivação desse ensaio foi um "rascunho sobre o tema Cosmos e o Segundo axioma principal” (p. 9) que um amigo lhe enviou para uma leitura crítica. Ao responder a tese central do artigo, Jonas se deixou levar por uma reflexão mais profunda que resultou nos 18 artículos ali reunidos. Desses, os dois primeiros discutem o conceito inicial do título (a questão da matéria), os três seguintes, a noção do espírito e do 6 ao 16 Jonas se dedica à reflexão sobre Deus ${ }^{1}$. Dada a complexidade do último tópico, na presente exposição, pretende-se fazer apenas uma breve introdução à cosmologia jonasiana abordando somente os dois primeiros elementos: Matéria e Espírito, deixando a mais extensa discussão sobre a questão teológica, para uma oportunidade futura.

PALAVRAS-CHAVE: Hans Jonas; Cosmologia; Matéria; Espírito.

1. Nos dois últimos, Jonas propõe duas questões: a primeira sobre a possibilidade da filosofia especulativa (17) e sobre a relevância de se saber da existência de outras formas de vida inteligente no universo (18). 


\section{INTRODUÇÃO}

Para iniciar nossa exposição, é preciso evocar o contexto da obra Matéria, Espírito e Criação, exposto em seu Prefácio, lembrando que o seu principal mote foi um "rascunho" sobre o tema cosmos e o segundo axioma principal enviado a Jonas por seu amigo Max Himmelheber, para sua apreciação.

Partindo dessa motivação inicial, Jonas buscará explicar a tendência da matéria para criar das formas inferiores às superiores, ou seja, os organismos (desde os mais simples, até os mais complexos). Ele considera ser esse o primeiro passo para uma concepção cosmológica mais elaborada.

A hipótese defendida por Himmelheber é a de que no momento original do universo (identificado à explosão primordial), além da energia total do cosmos, surgiu também a informação, que Jonas, recorrendo à tradição grega, identifica ao logos cosmogônico, que ele entende como complementar ao conceito de eros cosmogônico, proposto por Ludwig Klages.

Jonas, inicialmente, apenas pretendia discordar do uso feito dos conceitos de informação ou logos por meio de uma breve carta e não responder com um ensaio inteiro. Mas, sem perceber, ao buscar esboçar uma contraposição aceitável, foi conduzido a uma especulação cosmogônica, no interior da qual se articularam "décadas de reflexões sobre ontologia e filosofia da natureza" (MEC, p. 10).

A breve carta cedeu lugar, assim, ao ensaio Materie, Geist und Shöpfung [Matéria, Espirito e Criação (MEC)], cujo motivo inicial explica o fato de ele começar pela contestação de uma hipótese. A partir daí segue, porém, um caminho próprio, retomando reflexões anteriores que, após longo período, voltariam a incitar o pensador.

Nesse ínterim, o "rascunho" inicial de Himmelheber ganhou forma no artigo intitulado “Die Trinität der Natur", publicado em 1988, no número 18 da revista Scheidewege, onde Jonas também publicou uma versão abreviada do MEC que, em maio do mesmo ano, ele proferiu como a terceira palestra do Congresso Internacional "Espírito e Natureza", realizado em Hanover.

Acerca do MEC, Jonas faz três considerações prévias relevantes. A primeira refere-se ao fato de seu tema central ter sido trabalhado mais detalhadamente em outros textos, que ele indicará ao longo do escrito, sempre que necessário.

A segunda refere-se à sequência das palavras do título: matéria, espírito e criação que refletem o curso de sua investigação, da qual resultaram os 18 artículos que compõem o volume, divididos, vale lembrar, da seguinte forma: os dois primeiros discutem o conceito inicial do título (a questão da matéria), os três seguintes, a noção de espírito; do 6 ao 16 Jonas se dedica à reflexão 
sobre Deus e, nos dois últimos, ele aborda duas questões de naturezas distintas, mas igualmente complexas: a primeira sobre a possibilidade da filosofia especulativa (17) e a segunda sobre a relevância de se saber se existem outras formas de vida inteligente no universo (18).

A terceira e última consideração prévia feita por Jonas refere-se ao aspecto metodológico, e ele afirma que

\begin{abstract}
$\mathrm{Na}$ exposição dos dados cosmológicos, portanto, avançamos do externo para o interno, e isto que dizer, desde o ponto de vista da história do ser, do anterior para o posterior; do ponto de vista quantitativo, do mais frequente para o mais raro; do ponto de vista estrutural, do mais simples para o mais complexo e, em termos de apreensão, do ver e sentir para o pensar - e deste pensar, enquanto mais interno, mais raro, e mais tardio, retornamos àquilo que é primeiríssimo, precedendo, inclusive, a matéria: dos dados cosmológicos para a conjectura cosmogônica... (MEC, p. 11) ${ }^{2}$
\end{abstract}

Como já antecipado, considerando a complexidade dos temas ali discutidos e o objetivo da presente exposição: fazer uma breve introdução à cosmologia jonasiana, apenas os dois primeiros elementos - Matéria e Espírito - serão aqui abordados, ficando a mais extensa discussão sobre a questão teológica, para uma oportunidade futura.

A apresentação será dividida em duas partes a primeira dedicada à exposição acerca do surgimento da Matéria e a segunda à exposição acerca do surgimento do Espírito, seguidas de breves considerações finais.

\title{
1) O SURGIMENTO DA MATÉRIA
}

Ainda no Prefácio à obra MEC, Jonas antecipa a perspectiva a partir da qual sustentará sua posição para contestar a tese de Himmelheber, ao dizer: "Na exposição dos dados cosmológicos, o fator evolutivo é decisivo e, em relação à substância do mundo (Weltmaterie), sempre igual e subjacente a tudo" (MEC. p.11).

Essa premissa inicial levanta, porém, uma questão primordial, assim por ele formulada: "a partir de que princípio de progresso pode ser explicada a sua evolução, cósmica em geral e só depois especificamente terrestre, até as formas mais sutis do mundo orgânico?” (MEC. p.11).

Jonas reforça a dificuldade da questão acima, apontando o fato desconcertante de que, seja qual for o princípio que tenha iniciado esse longo processo de evolução, ele o fez contrariando a "lógica" entrópica, que conduz necessariamente da ordem ao caos. Razão pela qual ele declara: “O enigma aí é a direção fisicamente improvável, e antientrópica, do caos para a ordem (só a [direção] inversa é provável)". (MEC. p. 11)

2. Esse percurso metodológico que Jonas adota faz lembrar a 'regra de ouro', proposta por Descartes em seu célebre Discurso sobre o método, ou seja, a terceira regra ou sintese, etapa em que se deve conduzir a investigação do mais simples para o mais complexo, do que é mais concreto ao que é mais abstrato. 
Em seguida, para finalizar o prefácio, Jonas explicita a questão que está na raiz dessa reflexão. Trata-se da utilidade do conceito de "informação", que ele aqui identifica à ideia de programação, a qual já estaria, segundo Himmelheber, presente no "substrato material do mundo (Weltstoff)", pois, teria surgido na "explosão primordial" e estaria a conduzir "a marcha evolutiva do vir-a-ser do cosmos” (MEC. p.11), desde as partículas elementares às organizações mais complexas.

Cabe notar que temos aqui retomada a questão inicial da filosofia concernente à arqué. Não como a maioria dos pré-socráticos a entendiam, como a busca pelo elemento primordial, mas, como vista por alguns, entre os quais Heráclito, como a busca pelo princípio elementar que gerou o movimento originário de tudo.

Por isso, não sem razão, como já mencionado, Jonas identifica essa "informação" original ao conceito grego de "logos cosmogônico". O que explica, portanto, o título do primeiro capítulo - "Logos cosmogônico? Por que não se pode admitir uma 'informação' na matéria primordial" que fornece, simultaneamente, a pergunta e a resposta propostas por ele.

De saída, Jonas aponta a principal característica que identifica na "informação" para justificar sua recusa, dado que, a seu ver, ela “já requer por si mesma, como seu substrato físico, um sistema diferenciado e estável, tal como o é o sistema molecular completamente articulado e constante do genoma dos seres vivos (ou do mesmo modo, em termos magnéticos, a programação - o software - do computador)." (MEC. p.13. Grifos nossos)

Desse modo, o conceito de informação, como Jonas esclarece, não é causa, mas consequência, resultado, efeito de um tipo de organização prévia, que "se perpetua, mas não se sobreleva" (MEC. p.13). Isso equivale a dizer que a informação, gerada no interior de um sistema, pode se conservar, mas, jamais prescindir ou ser anterior ao próprio sistema que a tornou possível.

Além disso, Jonas adverte que as duas exigências, grifadas acima, para a produção da informação: articulação e estabilidade, não podem ser pressupostas no instante de "total indiferenciação e total dinâmica da (hipotética) 'substância' da explosão primordial - ou de modo geral, no 'caos' - a hipótese de um logos cosmológico ou, de outro modo, toda programação preestabelecida e plano rigoroso, residindo já desde o início no interior da matéria nascente, é descartável como um modelo explicativo da evolução". (MEC. p.13) Sobretudo, porque, como Jonas assinala, toda informação exige uma acumulação (para sua articulação e estabilidade) que não pode ser pressuposta no instante da "explosão primordial".

Assim, ele constata que o conceito de "informação" fracassa tanto do ponto de vista lógico, quanto do ponto de vista "genético", ou seja, com relação à gênese do processo evolutivo que ela deveria elucidar, pois ela não é capaz de explicar "além de si mesma. Para isso, é 
necessário um fator transcendente que seja algo adicional e conduza ao novo. Jonas, então, se pergunta:] O que pode ser esse fator?” (MEC. p.14).

Ele antecipa sua inclinação a considerar que "por um lado, isso acontece de um modo mais trivial e anárquico, por outro, de um modo mais misterioso do que é sugerido pelo conceito de informação ou logos, em si mesmo tão compreensível, postulado retroativamente desde o resultado, mas em última instância determinístico. O primeiro aspecto se refere ao lado físico, e o outro, ao lado mental". (MEC. p.14)

Nesse sentido, Jonas defende que esse princípio ou "fator transcendente" originário não pode ser a informação ou o logos pelo simples fato de que, se assim fosse, todo o processo posterior teria sido determinado, conduzido inteiramente por essa 'mensagem prévia' e ele entende que todo movimento se deu de forma "trivial, anárquica" (na dimensão física: da matéria) e "misteriosa" (na dimensão mental: do espírito).

O que nos leva ao capítulo 2, em que Jonas apresenta "A alternativa ao logos - Do caos à ordem através da seleção natural". E no qual, mais uma vez, encontramos já no título a posição que será defendida por ele.

Assim, partindo daquele momento inicial, identificado ao caos, ou como Jonas o apresenta “do desorganizado e sem propósito no vir-a-ser da organização natural", ele acrescenta que "o fundamento de toda organização na natureza, quer dizer, de uma natureza em geral, encontra-se nas leis de conservação.” (MEC. p.15)

Jonas esclarece que tais leis se impuseram graças ao fato tautológico de que "apenas aquiloque-se conserva (Sich-Erhaltende) conserva a si mesmo". Ademais, a própria "regularidade da natureza" é um efeito "universal" da seleção que, a partir de então, estipula "as regras para as novas seleções, mais específicas e locais." (MEC. p.15)

Portanto, a origem das próprias leis da natureza remonta ao instante em que, no interior do "não regular", se precipitaram as primeiras "entidades estáveis, relativamente duradouras, que se comportam sempre (ou por longo tempo) da mesma forma e, desse modo, 'se impõem'.” (MEC. p.15) O que representa, para Jonas, o exemplo mais primordial da sobrevivência do mais apto.

Isso significa que "A ordem é mais bem-sucedida que o caos." (MEC. p.15) Pois, aquilo que não obedece a qualquer regularidade pode, em algum momento, ganhar existência, mas sucumbe, mais cedo ou mais tarde, devido à sua própria fugacidade. Enquanto o que é regular se mantém e vem a predominar. De modo que, de novo tautologicamente, “o transitório dá lugar ao duradouro exatamente por causa de sua transitoriedade.” (MEC. p.15).

Jonas atribui, assim, à lei da conservação o processo de "formação e proliferação dos prótons e, com eles, o domínio da gravitação e da mecânica; dos átomos de hidrogênio até o aparecimento dos 
elementos da tabela periódica e da química (inclusive a beleza dos cristais), em suma o reino da matéria". (MEC. pp.15-16.)

Todavia, Jonas reconhece que, tendo como origem o que é transitório, mesmo essas partículas elementares, embora extremamente duradouras, são também transitórias. Pois, ainda que seus "ciclos" se estendam imensamente como aqueles, por exemplo, das galáxias, das estrelas, dos sois e mesmo os da própria Terra, em algum momento, todos eles terão fim.

Isso levaria à incômoda questão: "para que então a evolução?” (MEC. p.17). Já que é para acabar, por que o cosmos não se conteve com aqueles elementos duráveis, mas "evoluiu" em direção às formações mais complexas, mas, também, mais "instáveis”? Jonas recorre a Darwin, (seu grande inspirador nessa reflexão) para responder que: "sempre permanece 'desorganização' suficiente para, ao acaso cego e isolado, somarem-se novas características (fatores estruturais) às formações existentes, ficando os acertos momentâneos sujeitos ao processo de seleção da evolução com seu critério meramente diferencial-numérico de sobrevivência.” (MEC. p.17).

O mais relevante é, porém, o que vem a seguir, quando Jonas afirma: "Este é o 'fator transcendente' requerido que conduz ao novo e então ao superior - sem pré-informação, sem logos, sem plano, e até mesmo sem impulso, mas apenas através da susceptibilidade de uma organização dada, que já é codificada de 'informação', à desorganização circundante que se the impõe como informação adicional”. (MEC. p.17).

Dito de outra maneira, Jonas encontra no mecanismo da seleção natural o fator transcendente que "age" de modo trivial e aleatório, "organizando" o caos para criar novas formas, deixando sempre um resto de indeterminação prenhe de novas possibilidades.

Com esse "fator", Jonas pondera, seria possível, explicar a progressão dos níveis mais elementares da matéria "até as formas de vida (...) mais complexas e sutis" se, como propôs Descartes, "elas não fossem mais que autômatos mecânicos". (MEC. pp. 17-18).

Todavia, como Jonas ressalta, "elas não são isso, mas algo mais" e a própria atividade de reflexão que está em curso, assinala um aspecto improvável, mas, paradoxalmente, inegável que vem a ser: a interioridade, ou subjetividade ou, ainda, consciência. E cujo surgimento, embora não possa ser explicado nem mesmo pela "mais completa e contínua descrição objetiva do cérebro, mesmo em suas estruturas mais finas e modos de funcionamento", segundo Jonas, será preciso "incluir ... em nossa imagem do universo, ... uma vez que ela tem origem no curso dos eventos naturais e aparece em forma natural..." (MEC. p. 18).

Eis o grande enigma que Jonas espera, então, enfrentar nos três próximos capítulos e sobre o que nos deteremos na segunda parte de nossa exposição.

\section{2) DA CONSCIÊNCIA AO ESPÍRITO}


Já no início do capítulo 3, intitulado, precisamente, "O enigma da subjetividade", Jonas adverte que se chega, assim, "ao misterioso, ao transfísico e ao imaterial”, pois, a subjetividade é um "dado ontológico fundamental no ser" (MEC. p. 19), indispensável para torná-lo completo, ao possibilitar toda e qualquer "manifestação de interesse, finalidade, objetivo, aspiração e desejo ... vontade e valor" (MEC. p. 19) e, por isso, reabre-se a questão teleológica, que parecia superada em favor da causalidade eficiente, suficiente apenas para explicar os "dados meramente físicos" (MEC. p. 19).

Entretanto, Jonas constata que o surgimento da interioridade (e com isso da subjetividade) na "esfera da vida, nos organismos, é um fato empírico" (MEC. p. 19). E ainda que seja fácil explicar o surgimento da dimensão orgânica a partir das propriedades físico-químicas que compõem a sua matéria, não é nada simples explicar o aparecimento da dimensão interna que se abre com o próprio processo de constituição dos organismos.

Nada há previamente na matéria que permita explicar a erupção da subjetividade e, por outro lado, não se pode simplesmente acrescentá-la post factum. Nem há qualquer "denominador comum" entre a "extensão" e a "consciência" (res extensa e res cogitans) e, entretanto, "elas existem juntas, não apenas uma ao lado da outra, mas de forma interdependente, uma interagindo com a outra e, mais exatamente, absolutamente, na "matéria" e (...) de forma inseparável (pois não temos qualquer experiência de um espírito sem corpo)." (MEC. p. 20).

Essa intrigante constatação, que ecoa o célebre dualismo cartesiano, conduz a duas questões cruciais: "Como pode o pensamento fazer frente a uma coisa como essa? [e] Que aparência deve ter uma doutrina do Ser para que faça justiça a tal enigma”? (MEC. p. 20).

Jonas nos relembra a longevidade dessa discussão que resultou em duas perspectivas: as dualistas e as monistas. As dualistas prevaleceram nas concepções metafísicas e religiosas: com Platão, Pascal e Kierkegaard no primeiro caso, Zaratustra, São Paulo e Santo Agostinho passando pelos órficos e gnósticos, no segundo; tendo, porém, em comum o fato de priorizarem a dimensão da alma em relação ao corpo.

Porém, Jonas entende que esse tipo de dualismo sucumbe frente ao "fenômeno da vida orgânica" que revela a indissociabilidade entre os dois, o que torna a radical separação cartesiana insustentável. Não há um corpo (vivo) sem alma e nem uma alma (consciência pura) sem corpo.

Jonas, assim, rejeita a concepção dualista cartesiana, mas, com isso, também a célebre visão socrático-platônica da "imortalidade da alma individual". (MEC. p. 21). 
Sua rejeição ao dualismo não significa, porém, sua adesão a um monismo que tende ao puro materialismo suprimindo a alma, o espírito e a consciência do fenômeno vida, restringindose a processos "físicos" que ocorrem no cérebro.

Jonas reconhece que esse monismo tem ainda mais problemas que o dualismo, mas, ainda assim, pretende buscar uma solução monista para tal "enigma, já que a voz da subjetividade nos animais e nos seres humanos emergiu dos mudos torvelinhos da matéria e a ela continua a se ligar." (MEC. p. 21).

Desse modo, apesar da grande dificuldade da questão e de seu alto teor especulativo, Jonas não se intimida e prossegue afirmando que

é a própria substância do mundo que, ao tornar-se interior, ganha, com isso expressão. (...) O que parece necessário, então, para a solução monista, é uma revisão ontológica, uma renovação do conceito de matéria para além da mensurabilidade exterior da física e que introduza novamente aqueles conteúdos que foram extraídos dela - portanto, uma meta-física do substrato material do mundo. (MEC. pp. 21-22).

Contudo, ele esclarece que oferece apenas uma exposição conjetural com o objetivo de submeter suas proposições, resultantes de décadas de reflexão, a exame.

Assim, já no início do capítulo 4, intitulado "Em que o dado da subjetividade contribui para os dados cosmológicos?", Jonas afirma que "o mínimo que devemos conceder à matéria que se desenvolveu a partir da explosão primordial, tendo em vista o que, por fim, surgiu depois, é uma disposição original com a possibilidade eventual de interioridade - não uma disposição com interioridade, nem mesmo uma disposição para a interioridade no sentido de já estar preparada para ela.” (MEC. p. 23).

Ou seja, ele explicita que a "potencialidade para algo" não pode ser confundida com o "serdisposto para algo" que pressupõe uma orientação prévia para uma "certa direção". Assim, a explicação de Jonas mantém-se modesta o suficiente para afirmar simplesmente que "a emergência de uma dimensão interior quando e onde quer que tenha ocorrido, e de sua existência real e presente em nós, é apenas o resultado quase trivial de que essa dimensão era 'possível' segundo as características da matéria como originalmente 'criada'." (MEC. p. 23).

Aqui, porém, a reflexão se complexifica, pois, conduz a duas questões desconcertantes: “quem (ou o quê) 'dispôs' a matéria de tal maneira? E: que porção teve essa 'disposição' no curso dos acontecimentos do mundo?" (MEC. p. 24) Estamos, aqui, diante da questão relativa à "vontade criadora" e de sua ação posterior no mundo.

Jonas pede cautela quanto ao uso do termo 'vontade' atribuído à causa primeira, mas, ainda assim, sustenta que é impossível supor que algo não indiferente (como a subjetividade) tenha se

3. Posição que, atualmente, tende a prosperar, pois há toda uma corrente da neurociência que, como se sabe, se ocupa precisamente de estudos que visam explicar até mesmo o "comportamento ético", unicamente, através das operações neuronais, a chamada "neuroética". 
originado de algo completamente "indiferente e neutro". (MEC. p. 24). É preciso supor, ao menos, uma espécie de "preferência favorável" já no "cerne da matéria", mesmo que sem um "plano" pré-determinado (o que foi de antemão descartado), mas como uma "tendência, um anseio, que se aproveita da oportunidade de uma causalidade do mundo e logo a leva adiante." (MEC. p. 24). E aqui Jonas oferece uma alternativa, quase poética, ao dizer que "um eros cosmogônico se aproxima mais da verdade do que um logos cosmogônico". (MEC. p. 24).

Ainda assim, ele afirma que todo o movimento se segue entregue ao acaso e, apesar do improvável, sempre que as condições favoráveis (como a vida no planeta Terra) se oferecem, a disposição se manifesta e se faz ato (para usar, aqui, uma terminologia aristotélica!). Desse modo, não é o puro acaso que está em jogo no improvável fenômeno de surgimento da vida.

Essa explicação jonasiana faz eco com algumas explicações pré-socráticas (como as de Empédocles, Heráclito e Parmênides) que atribuem às divindades (do Amor e do Ódio) a ação inicial que reuniu ou separou os elementos para a constituição do cosmos. Mas, também, se aproxima à noção freudiana de Eros e Tânatos, como pulsão (impulso) de vida e pulsão de morte.

Tais aproximações, talvez, possam tornar mais compreensível a afirmação de Jonas de que "a vida é um fim para si mesma” [quase que por esse 'impulso' que a projeta e conduz]. Sendo "um fim que se quer e se persegue ativamente". (MEC. p. 25).

Nesse sentido, Jonas pode, então, declarar que "desde a origem, a matéria é subjetividade em estado latente, ainda que éons, somados a uma sorte excepcional, tenham sido necessários para a atualização desse potencial.” (MEC. p. 24). Ele acrescenta que o testemunho da vida nos abre um caminho em direção à teleologia.

Ele resume todo o seu argumento, até aqui, dizendo que estando a finalidade presente nos seres vivos, inicialmente de forma subjetiva, para se efetivar objetivamente e causal, ela não pode estar ausente na natureza, de onde ela emerge. Daí, Jonas pode extrair não apenas a presença de fins na natureza, mas a própria dimensão do valor.

Jonas ressalta ainda que toda essa reflexão foi possível sem recorrer a uma transcendência, apenas à "voz da imanência que fala por si mesma." (MEC. p. 27).

Todavia, até o momento, o espírito, propriamente dito, ainda não emergiu e é no capítulo 5 que ele vai discutir a interessante questão da "Liberdade transcendente do espírito".

Jonas começa explicitando que quem está realizando essa reflexão somos nós mesmos ou, melhor, o nosso pensamento [lembramos aqui o cogito cartesiano]. Assim, "ao testemunho vital é acrescido o testemunho antrópico e, com isso, certamente se abre um horizonte de transcendência" (MEC. p. 29), que se manifesta triplamente na "liberdade do pensar": 1) Liberdade de autodeterminação do pensamento (ele próprio define sobre o que pensar). 2. Liberdade de transformar o dado sensível em uma imagem interior (liberdade inventiva da imaginação) e 3) Graças à linguagem: 
liberdade de ir além de tudo o que é predeterminado: da existência para a essência, do finito para o infinito, do temporal para o eterno, etc.” (MEC. p. 29).

Jonas declara, a seguir que "Todas as três liberdades são prerrogativas exclusivas do espírito que apontam para o 'transanimal no homem'.” (MEC. p. 30).

E, com essa reflexão, Jonas oferece uma interessante concepção acerca da emergência do espírito, a partir do despertar da consciência que emergiu, por sua vez, da evolução das formas vivas, tornadas possíveis pela explosão primordial que ofereceu a matéria-prima para formar tudo o que existe no universo.

\section{CONSIDERAÇÕES FINAIS}

Para fechar essa exposição, é preciso apontar que não serão apresentadas aqui, como seria de se esperar, uma conclusão nem mesmo considerações finais, no sentido de um arremate definitivo da discussão proposta. Pois, isso implicaria a abordagem dos demais opúsculos do MEC, o que não foi possível dada a limitação de tempo para preparar e apresentar toda a complexa reflexão ali oferecida por Jonas.

Desse modo, como apenas os dois primeiros temas - matéria e espírito - foram então focalizados, o que se propõe, por ora, são mais exatamente meras 'considerações parciais' acerca da cosmologia jonasiana, brilhantemente sintetizada no MEC.

Além de parciais, tais considerações pretendem apenas retomar e sumariar o que Jonas abordou nos cinco primeiros ensaios, visando a preparação para uma futura exposição dos demais ensaios que compõem o volume. Sendo assim, vimos que:

No primeiro ensaio, - "Logos cosmogônico? Por que não se pode admitir uma 'informação' na matéria primordial" -, já no título, Jonas propôs, simultaneamente, uma pergunta e a resposta à tal questão. A premissa que ele assentou foi a de que o traço principal de toda informação é requerer um sistema diferenciado e estável, como seu substrato físico. Destarte, ele defendeu que, para haver uma informação, é necessário um sistema organizado no interior do qual tal informação possa ser constituída.

Nesse sentido, o conceito de informação, como Jonas esclareceu, não é causa, mas consequência, resultado, efeito de um tipo de organização prévia. E como as duas exigências para a produção da informação: articulação e estabilidade, não podem ser pressupostas no instante totalmente indiferenciado e caótico da explosão primordial, "a hipótese de um logos cosmológico ou, de outro modo, toda programação preestabelecida e plano rigoroso, residindo já desde o início no interior da matéria nascente, é descartável como um modelo explicativo da evolução”. (MEC. p.13) 
Portanto, o conceito de "informação", como algo presente na matéria primordial, fracassou tanto do ponto de vista lógico, quanto do ponto de vista "genético". O que nos levou ao capítulo 2, no qual Jonas apresentou "A alternativa ao logos - Do caos à ordem através da seleção natural". Em que, mais uma vez, encontramos já no título a posição defendida por ele.

Assim, partindo daquele momento inicial, identificado ao caos, ou como Jonas o apresentou "do desorganizado e sem propósito no vir-a-ser da organização natural”, ele acrescentou que "o fundamento de toda organização na natureza, quer dizer, de uma natureza em geral, encontra-se nas leis de conservação.” (MEC. p.15)

Vimos que Jonas atribuiu à lei da conservação o processo de "formação e proliferação dos prótons e, com eles, o domínio da gravitação e da mecânica; dos átomos de hidrogênio até o aparecimento dos elementos da tabela periódica e da química (inclusive a beleza dos cristais), em suma o reino da matéria”. (MEC. pp.15-16.)

Entretanto, para além dessa lei da conservação, ele reconheceu que, tendo como origem o que é transitório, mesmo essas partículas elementares, embora extremamente duradouras, são também transitórias. Pois, ainda que seus "ciclos" se estendam imensamente como aqueles, por exemplo, das galáxias, das estrelas, dos sois e mesmo os da própria Terra, em algum momento, tudo isso terá fim.

Chegamos, assim, à incômoda questão quanto à finalidade de todo o processo evolutivo. Pois, já que é para acabar, por que o cosmos não se conteve com aqueles elementos duráveis, mas "evoluiu" em direção às formações mais complexas, mas, também, mais "instáveis"? Jonas, inspirado por Darwin, encontrou no mecanismo da seleção natural o fator transcendente que "age" de modo trivial e aleatório, "organizando" o caos para criar novas formas, suprimindo aquelas menos aptas, deixando sempre, porém, um resto de indeterminação repleto de novas possibilidades.

Embora com esse "fator" tenha sido possível explicar a progressão dos níveis mais elementares da matéria "até as formas de vida (...) mais complexas e sutis" (MEC. p. 17), como Jonas indicou, elas se tornaram algo mais que a mera função biológica e a atividade de reflexão revela um aspecto improvável, mas, paradoxalmente, inegável que é a interioridade, ou subjetividade ou, ainda, consciência.

Com efeito, o surgimento da consciência criou um problema ainda mais desconcertante e, embora não possa ser explicado nem mesmo pela "mais completa e contínua descrição objetiva do cérebro, mesmo em suas estruturas mais finas e modos de funcionamento" (MEC. p. 18), Jonas viu a necessidade de enfrentá-lo em sua cosmologia, pois, a consciência é um fenômeno natural como tantos outros que desafiam o entendimento humano, sendo, entretanto, um dos mais instigantes. 
Esse grande enigma foi enfrentado por Jonas nos três capítulos seguintes e a eles foi dedicada a segunda parte de nossa exposição.

No capítulo 3, intitulado exatamente "O enigma da subjetividade", Jonas iniciou a reflexão acerca do surgimento da consciência e da sua relação com o seu substrato material; retomando, ali, um dos mais intrincados problemas filosóficos, pois, embora a consciência seja um dado empírico, não há nada de antemão na matéria que permita explicar o seu advento. Ainda assim, nosso autor assinalou que ela não pode, simplesmente, ser acrescentada post factum. Logo, era preciso descobrir o que, desde o início, tornou possível a emergência da consciência.

Ademais, nada há em comum entre a "extensão" e a "consciência" (res extensa e res cogitans) e, apesar disso, "elas existem juntas, não apenas uma ao lado da outra, mas de forma interdependente, uma interagindo com a outra e, (...) de forma inseparável (pois não temos qualquer experiência de um espírito sem corpo)." (MEC. p. 20).

Jonas se deparou, então, com o clássico problema cartesiano, reconhecendo que ele já está presente desde Platão e que, ao longo da tradição, as inúmeras tentativas de solucioná-lo podem ser divididas em duas tendências básicas: as monistas e as dualistas. Ele fez críticas às duas posições, mas, assumiu que sua própria concepção tenderia mais ao monismo, ainda que não de tipo radical, e que para superar a separação, então, intransponível entre res extensa e res cogitans seria preciso uma revisão ontológica da dimensão material, reduzida por Descartes e pela Física à sua mensurabilidade.

No capítulo 4, intitulado "Em que o dado da subjetividade contribui para os dados cosmológicos?", Jonas sugeriu que para explicar o advento da consciência, devemos, ao menos, atribuir à matéria resultante da explosão primordial, "uma disposição original com a possibilidade eventual de interioridade - não uma disposição com interioridade, nem mesmo uma disposição para a interioridade no sentido de já estar preparada para ela." (MEC. p. 23).

Ele quis distinguir entre a "potencialidade para algo" e o "ser-disposto para algo" que pressupõe uma orientação prévia para uma "certa direção". Assim, sua explicação se manteve modesta o suficiente para afirmar simplesmente que "a emergência de uma dimensão interior quando e onde quer que tenha ocorrido, e de sua existência real e presente em nós, é apenas o resultado quase trivial de que essa dimensão era 'possível' segundo as características da matéria como originalmente 'criada'." (MEC. p. 23).

Porém, tal suposição tornou ainda mais complexa a discussão ao precipitar duas questões desconcertantes: “quem (ou o quê) 'dispôs' a matéria de tal maneira? E: que parcela teve essa 'disposição' no curso dos acontecimentos do mundo?’ Ou seja, emergiu o problema relativo à "vontade criadora" e de sua ação posterior no mundo. 
E, embora pedindo cautela quanto ao uso do termo 'vontade' atribuído à causa primeira, Jonas ofereceu uma alternativa, quase poética, ao dizer que "um eros cosmogônico se aproxima mais da verdade do que um logos cosmogônico". (MEC. p. 24). Ele ressaltou ainda que realizou toda essa reflexão sem recorrer a uma transcendência, apenas à "voz da imanência que fala por si mesma." (MEC. p. 27).

Contudo, até aqui, não se explicou a emergência do espírito, propriamente dito, e foi no capítulo 5 que ele discutiu a relevante questão da "Liberdade transcendente do espírito".

Jonas começou lembrando-nos que quem está realizando essa reflexão somos nós mesmos ou, mais exatamente, o nosso pensamento [semelhantemente ao argumento do cogito cartesiano]. Desse modo, à dimensão vital foi acrescentada a dimensão antrópica com o que se abriu, necessariamente, "um horizonte de transcendência" (MEC. p. 29), que se manifesta na tripla "liberdade do pensar", assim especificada: "1) Liberdade de autodeterminação do pensamento (ele próprio define sobre o que pensar). 2. Liberdade de transformar o dado sensível em uma imagem interior (liberdade inventiva da imaginação) e 3) Graças à linguagem: liberdade de ir além de tudo o que é predeterminado: da existência para a essência, do finito para o infinito, do temporal para o eterno, etc." (MEC. p. 29)

E como Jonas ressaltou, "Todas as três liberdade são prerrogativas exclusivas do espírito que apontam para o 'transanimal no homem'.” (MEC. p. 30).

Desse modo, por meio dessa brilhante especulação, Jonas demonstrou como se deu o surgimento da matéria (no plano físico e químico), a emergência da consciência (na esfera biológica) e o despertar do espírito (na dimensão antrópica), sem recorrer a qualquer transcendência.

Porém, nos capítulos seguintes (6 a 16), ele dará um passo ainda maior em seu percurso especulativo e enfrentará a árdua questão teológica, na longa reflexão dedicada ao terceiro termo do título, isto é, a Criação.

Embora a questão intrigante de saber como ele conciliará a reflexão que evitou todo recurso à transcendência com a hipótese da criação instigue nossa curiosidade, a resposta ficará para outra oportunidade e, a quem não puder se conter até lá, fica o convite à leitura dessa cativante obra jonasiana.

\section{REFERÊNCIA}

JONAS, Hans. Matéria, Espírito e Criação. Petrópolis: Vozes, 2010. 


\section{OS CAMINHOS CRUZADOS ENTRE ÉTICA E METAFÍSICA NO CONCEITO DE RESPONSABILIDADE}

The Cross Paths between Ethic and Metaphysics in the Responsibility Concept

\section{Luciano Gomes Brazil}

Mestre em Filosofia pelo IFCS-UFRJ

RESUMO: O presente artigo, em verdade um pré-projeto de doutorado, procura entender o status da Responsabilidade no âmbito ético metafísico da obra de Hans Jonas, em específico $O$ Princípio Responsabilidade. O elementar dessa pesquisa é a pergunta de como se dá essa relação entre aquilo que é ético e aquilo que é metafísico, pois ao esmiuçar o lugar dos fins no ser, estabelecendo os fins imanentes, e em seguida ao fazer a passagem da doutrina dos fins para a doutrina do valor, estabelecendo aquilo que tem valor imanente; ao realocar o homem no todo da vida a partir de uma nova interpretação sobre o organismo, a Responsabilidade redimensiona o homem em sua relação com o mundo e consigo mesmo. O pré-projeto pergunta que metafísica é essa que gera uma ética da responsabilidade; como se dá essa relação entre ética e metafísica e como ela se sustenta.

PALAVRAS-CHAVE: Deontologia; Responsabilidade; Hans Jonas; Técnica; Ética.

ABSTRACT: The present article, in fact a pre-project of $\mathrm{PhD}$, looks to know the status of Responsibility in the scope metaphysical ethic of the work of Hans Jonas, specifically The Principle Responsibility. The elementary of that search is the the question of how happens that relation between that is ethical and that is metaphysical, for to scrutinize the place of the ends in the Being, establishing Immanent ends, and after that, when making the passage of the ism of ends to the ism of value, establishing that what has immanent value; when reallocate the Man in the all of life starting from a new interpretation about the organism, the Responsibility resize the man in his relation with the world and himself. The pre project ask for what metaphysic is this that generates an ethics of Responsibility; how it happens that relation between ethic and metaphysic and how it sustain itself.

KEYWORDS: Deontology; Responsability; Hans Jonas; Technic; Ethic. 
O Princípio Responsabilidade, obra monumental de Hans Jonas e publicada em 1979, propõe uma renovação da deontologia a partir de pressupostos inéditos para a história da ética. Tal ineditismo, porém, não é conduzido por Jonas sem um explícito engajamento na história dos problemas da disciplina ética e àquilo que lhe é exigido. O texto a seguir procura se inserir nesta exigência a partir de um problema ou dificuldade que surge já mesmo em seu título, e que, dentro dos recursos exegéticos que dispomos aqui tentaremos, ao invés de responder, colocar as perguntas corretas para um projeto que se abre. Ou seja, não é compromisso deste artigo responder ou mesmo dar conta de uma possível resposta a possíveis problemas, mas sim colocar as devidas questões e formulá-las de acordo com o que um projeto de doutoramento nos cobra.

Para que o caminho a ser feito seja o melhor possível, deixemos bem claro o que precisamos primeiro estabelecer. Há três pontos fundamentais que gostaria de seguir:

O primeiro diz respeito, e deixemos que isso soe já de antemão, antes mesmo de nos engajarmos à leitura do texto, diz respeito ao fato de que Jonas se propõe uma renovação da deontologia, isto é, à ética do dever; o segundo ponto é que Jonas funda essa deontologia a partir da metafísica, e este é o ponto que considero central nos problemas que pretendo abrir neste projeto: o de que Jonas trabalha com algo como um imbricamento ético metafísico para a sua deontologia; o terceiro ponto é que essa ética deontológica imbricada em uma metafísica surge em meio ao universo tecnológico contemporâneo e àquilo que ele exige de nós enquanto seres humanos.

Cada uma das afirmações acima carece de elucidação, e é o que faremos a seguir. Jonas nomeia o livro em questão de O Princípio Responsabilidade, e indica no subtítulo que se trata de um “ensaio de uma ética para a civilização tecnológica”. O ponto de partida é, então, a civilização tecnológica. O que é que essa dita civilização tecnológica exige e qual a sua grande novidade em face ao passado? Jonas nos fala de uma "natureza modificada do agir humano". O que isso quer dizer?

Ele nota uma alteração da ação humana, de sua própria natureza, agora imbricada com um poder tecnológico de longo alcance. Para dizermos em poucas palavras, a natureza modificada mencionada pelo autor alemão é o agir do homem no mundo contemporâneo da técnica. É a técnica, em última instância, que determina essa natureza modificada do agir. Através da realização da técnica, o homem de hoje se vê diante de desafios inéditos, pois o poder da ação través dela apresenta ao agente novos objetos, que em sua totalidade engloba a "biosfera inteira do planeta".

\footnotetext{
${ }^{1}$ JONAS, Hans. O Princípio Responsabilidade: ensaio de uma ética para a civilização tecnológica. Tradução de Marijane Lisboa e Luiz Barros Montez. Rio de Janeiro: Contraponto: ed. PUC-RJ, 2006, p.26
} 
Em sua relação com a natureza (mundo natural), por outro lado, a situação se inverte. Partindo de um paradigma ético, o "exemplo da antiguidade", exemplar no famoso canto do coro trágico de Antígona, peça teatral de Sófocles, Jonas demonstra que nessa antiguidade longínqua o homem ao mesmo tempo em que se pronunciava de um modo bastante altivo quanto ao poder de sua ação, permanecia ainda submetido a um poder infinito do próprio mundo natural: "O que ali não está dito, mas que estava implícito para aquela época, é a consciência de que, a despeito de toda grandeza ilimitada de sua engenhosidade, o homem, confrontado com os elementos, continua pequeno"2.

Criatura admirável, mais admirável dentre todas, o homem não dispunha de condições de se alçar sobre esse dito mundo natural, e isso sequer era colocado sob suspeita. Os recursos não eram esgotáveis e os ciclos não eram alterados ${ }^{3}$.

Como dissemos, essa relação se inverte no mundo contemporâneo. Os caminhos que conduzem a esta alteração não podem ser alienados de um estudo que se pergunta por uma ética contemporânea. Os questionamentos acerca da técnica envolvem o lugar que o homem coloca a si próprio no interior do mundo natural; o lugar e o status que o mundo natural ocupa na sua compreensão acerca do agir, do saber e do poder. Em suma, há toda uma nova dimensão que se descortina a partir da constatação disso que Jonas chama de "natureza modificada do agir humano":

já que a ética tem a ver com o agir, a consequência lógica disso é que a natureza modificada do agir humano também impõe uma modificação da ética. E isso não somente no sentido de que os novos objetos do agir ampliaram materialmente o domínio dos casos aos quais se devem aplicar as regras de conduta em vigor, mas em um sentido muito mais radical, pois a natureza qualitativamente nova de muitas das nossas ações descortinou uma dimensão inteiramente nova do significado ético, não prevista nas perspectivas e nos cânones da ética tradicional. ${ }^{4}$

De algum modo a ação humana atingiu um poder e uma capacidade de gerar efeitos que o mundo natural finalmente se mostrou frágil ante a tal ação. $\mathrm{O}$ instrumento para esses efeitos é o que chamamos tradicionalmente de técnica: o universo tecnológico é o reino da técnica que submete a natureza e os homens a seu poder. De algum modo a técnica como instrumento dá lugar a uma tecnologia autômata e é ela quem determina o seu próprio progresso.

O nosso autor nos fala, no segundo capítulo, de uma "dinâmica cumulativa dos desenvolvimentos éticos" ${ }^{5}$. Essa constatação se soma a outra, que remete ao perigo exposto da evolução tecnológica que é inversamente proporcional à evolução natural: a de que a cada passo

\footnotetext{
2 Id.Ib., p. 29

${ }^{3}$ Id.Ib.,p.32

${ }^{4}$ Id.Ib., p.32

5 Id.Ib., p. 78
} 
dado pelo progresso técnico, mais abismal se tornam suas relações. Além de serem irreversíveis os avanços, eles são cumulativos, isto é, eles cobram mais e mais rigor tecnológico para o passo seguinte. Talvez seja nessa medida que Jonas constate que o grande perigo do mundo contemporâneo não esteja do lado do seu fracasso, mas justamente de seu sucesso, e por isso exige de nós uma certa humildade, uma humildade que reconheça o poder supremo de nossas ações. É que se na antiguidade o poder de nossas ações cobrava dos pensadores uma ética imediata, sem refletir sobre um longo alcance da ação - simplesmente porque esses efeitos longos inexistiam -, o mundo contemporâneo da tecnologia nos exige uma nova ética, e não basta a ela apenas hiperdimensionar os efeitos ativos da humanidade e de sua tecnologia, mas de se valer de uma profunda pergunta metafísica e que gere consequentemente um sentimento de responsabilidade desse homem contemporâneo.

Jonas ao apresentar essa natureza modificada do agir e situar um poder de intervenção que atue numa esfera global, não está apenas hiperdimensionando o objeto de reflexão ética, mas atravessando campos de saberes supostamente distintos, ou seja, saindo da ética, que tradicionalmente coloca a pergunta do agir (o que fazer, como fazer) para o âmbito da metafísica (qual o fundamento para determinada ação). É isso o que o próprio Jonas diz após apresentar a natureza modificada do agir humano: “estender a reflexão sobre as alterações mencionadas e avançar além da doutrina do agir, ou seja, da ética, até a doutrina do existir ou seja, da metafísica, na qual afinal toda ética deve estar fundada",

Portanto, para elucidarmos aquele terceiro ponto, que foi de onde partimos, o autor de The Phenomenon of Life constata um poder de causar efeitos muito superior a tudo o que já fora pensado por todas as éticas e conjunto de valores tradicionais. Mas a incrível capacidade hiperdimensionada gera não somente que se tenha também uma atenção hiperdimensionada de seus efeitos. É preciso reconhecer que o poder de atuação do mundo tecnológico atual faz cair sobre os nossos braços a decisão pela consequência, uma decisão que envolve uma amplitude de decisão não mais ao que as éticas tradicionais elegeram como seus objetos: o próprio homem, não apenas somente o homem, mas o homem de agora, da relação imediata, ao "círculo imediato da ação"”. É justamente o Bem que agora assume outra significação e que precisa ser indagado tendo em vista que o objeto da ação humana não mais se delimita ao imediato do efeito individual. O filósofo alemão entende que o caminho para se elucidar esse dilema ético é chegar aos questionamentos da doutrina metafísica, que é o que se pergunta e decide acerca da existência das coisas em geral. Assim, passamos do terceiro ponto ao segundo. Note-se que ainda não mencionamos qualquer hipótese ao dever.

\footnotetext{
${ }^{6}$ Id.Ib., p.42
}

${ }^{7}$ Id.Ib., p. 36 
Mas há algo que precisa ser esclarecido e que de certa forma antepõe o que virá a seguir. Antes mesmo de fundamentar a ética, Jonas dedica todo um capítulo a "Questões de Princípio e Método", e é neste capítulo que se estabelece a "heurística do Temor". A reflexão sobre o Bem elege para si próprio uma delimitação. Cito Jonas: “o reconhecimento do malum é infinitamente mais fácil do que o do bonum, é mais imediato, mais urgente, bem menos exposto a diferenças de opinião; acima de tudo, ele não é procurado"”.

O contexto de reflexão da citação acima é o futuro como problema. O núcleo de onde brota toda a questão da teoria da Responsabilidade é a possibilidade, não mais virtual, de aniquilamento de espécies inteiras, é o sentimento apocalíptico de aniquilação. A heurística do temor é:

tomar o temor como procedimento heurístico. Mas que conhecimento está implicado aí? 'Trata-se do conhecimento da 'futurologia', que Jonas define como a 'projeção cientificamente informada do que nossos atos presentes podem causalmente conduzir ${ }^{10}$

É uma passagem crucial nessa teoria ética, pois a fundamentação dessa metafísica estabelecida por Jonas de algum modo elege seus objetos a partir de um elo afetivo, porém não pelo caminho do desejo, mas do temor, o que para o autor é motivo de um importante questionamento. É um passo importante na teoria da Responsabilidade, onde Jonas precisa refutar, sobretudo, Kant. Cabe lembrar ainda que uma heurística do Temor cobra dessa ética um comprometimento teórico, um conhecimento, que, no entanto, não se limita ao científico. Cito o autor:

Dissemos que a verdade nele [do dever] buscada seria uma questão de conhecimento científico: pois, assim como os empreendimentos (cujas consequências posteriores devemos conhecer pela extrapolação) só se viabilizam por meio da ciência, da mesma forma essa extrapolação requer, no mínimo, o mesmo grau de ciência utilizado nos próprios empreendimentos. Entretanto, ela exige de fato um grau maior. Pois o que basta para um prognóstico de curto prazo, intrínseco a todas as obras da civilização técnica, não pode bastar para o prognóstico de longo prazo almejado na extrapolação requerida pela ética. A certeza de que desfruta a primeira, e sem a qual a empresa tecnológica inteira não poderia funcionar, encontra-se para sempre recusada à outra ${ }^{11}$.

A relação e a tensão entre a techné, conhecimento (epistemê) e a ética é, desde os antigos, um motivo de discussão. Considero esse um capítulo importante de discussão e problematização para

\footnotetext{
¿ Segundo as indicações de Wendel Evangelista, a palavra adequada para se utilizar é "Temor", e não "Medo".

${ }^{9}$ Op.cit. 2006. P. 71

${ }^{10}$ EVANGELISTA, Wendel. A Fundamentação Metafísica do Princípio Responsabilidade em Hans Jonas. 2008. $140 \mathrm{f}$. Dissertação (Mestrado em Filosofia) - Faculdade Jesuíta de Filosofia e Teologia, Belo Horizonte. <Disponível em http://www.faculdadejesuita.edu.br/documentos/180915-K9SrJvvkVEd.pdf acessado em 05 julho 2016>. P.103 11 Op.Cit. 2006, p.73
} 
os questionamentos necessários acerca do lugar metafísico dessa ética da responsabilidade. Sabemos que para Sócrates, o conhecimento do Bem envolvia necessariamente a realização desse Bem. Mas que tipo de conhecimento era esse? Por que necessariamente o conhecimento do Bem envolve um comprometimento ético do agente? Bem diferente é o entendimento acerca desse tema no interior da filosofia cristã, para quem conhecer o bem não necessariamente remete à sua realização. Para Agostinho, o livre arbítrio humano, origem do mal, impõe a distância entre o conhecer o Bem e o fazer o Bem. O quanto essa discussão inteira é importante e contribui para o debate acima? No mundo tecnológico, a possibilidade de aniquilação, individual ou coletiva, convive com as atividades mais habituais. O quanto a concepção de Bem do mundo antigo, e de Mal, da filosofia cristã, pode nos favorecer acerca da instigante questão da responsabilidade e com o futuro? O quanto o conhecimento científico pode nos favorecer quanto à promoção do Bem? Onde reside o limite de sua atuação?

Jonas nos diz que a ética deve buscar sua fundamentação lá na metafísica, que é a "doutrina do existir". Dissemos acima que há algo como um imbricamento entre ética e metafísica, que em algum lugar elas são, podemos afirmar, inerentes, ou ao menos se confundem. Conhecer as suas fronteiras é o objetivo deste projeto, é em virtude dele que se dá o engajamento às questões jonasianas.

Hans Jonas propõe uma ética deontológica. Ele resgata do constructo moral kantiano a noção de dever. E é justamente em seus fundamentos, ou seja, em sua metafísica, onde ele mais irá discordar de seu conterrâneo alemão. A relação de Kant com a metafísica nós já conhecemos, ainda que a conclusão acerca desta não possa nunca ser feita isenta de discussões: Kant estabelecera a impossibilidade de conhecimento dos objetos metafísicos: Deus, alma e mundo como um todo, algo que de algum modo irá se relacionar com a fundamentação de uma metafísica dos costumes (pois se assenta sobre a clássica distinção kantiana entre filosofia pura e empírica $^{12}$ ). Que a metafísica kantiana a partir da perda do objeto metafísico conhecido através de meros conceitos tenha se compensado numa ética fundamentada metafisicamente não é nosso principal interesse aqui (apesar de acenarmos para este tema como questão secundária), mas que essa ética kantiana tenha se fundamentado a partir da homologia entre vontade e razão é demasiado importante para ressaltar a quebra jonasiana de paradigma e, portanto, se relaciona diretamente com a nossa questão principal. Jonas: “o que importa são as coisas, e não o estado de

\footnotetext{
${ }^{12}$ KANT, Immanuel. Fundamentação da Metafísica dos Costumes. Tradução, introdução e notas de Guido Antônio de Almeida. São Paulo: Discurso Editorial: Barcarolla, 2009 (Coleções Philosophia), Prefácio
} 
minha vontade" ${ }^{\prime 13}$. O deslocamento jonasiano parece ter pressupostos fenomenológicos, e esta base metodológica não é novidade na crítica ao formalismo kantiano ${ }^{14}$.

Jonas, porém, foi além. É desde a sua base ontológica que a ética da Responsabilidade mostra ao que veio. Ao derivar valor imanente da finalidade imanente, Jonas está em verdade estabelecendo que a possibilidade de um valor, que coincide com a capacidade de ter fins, já é em si um valor ${ }^{15}$. Assim, para cada ente, o exercício de sua finalidade imanente lhe dá a dignidade própria, ou seja, a não indiferença em função de si mesmo já é um valor imensurável ante o não ser. Já aqui Jonas fala de maneira bastante distinta da fenomenologia. O que esta posição dos fins no Ser carrega de novidade ante as teorias tradicionais? Primeiramente, ela desloca a centralidade da subjetividade e da racionalidade humana, tradicionalmente (ao menos, e de maneira gradualmente mais incisiva na modernidade) detentora do telos, para o todo da vida.

Até aqui não temos ainda uma ética, apenas uma ontologia ou uma ontobiologia que modifica o locus do homem no todo da natureza. Mas não é justamente esta a nossa questão? $\mathrm{O}$ quanto a ontologia ela própria já nos apresenta tudo aquilo que a ética tratará de resolver? É justamente em face do lugar no todo da vida que se ergue a construção ética. Que essa construção tenha de ser em face de um dever ser, é em torno disto que gira toda a problemática: como elucidar essa deontologia? Que pressupostos devem estar contidos na noção de imanência dos fins para que eles possam realizar a contundência de um dever ser? A imanência dos fins e a teoria da responsabilidade dão conta de pensar os problemas contemporâneos? A exigência ética de nosso tempo carece de algo como uma fundamentação metafísica? Que metafísica é essa de que carece a ética? Sabemos que a ética que se segue é inteiramente baseada no locus que descentraliza o homem do antropocentrismo racionalista. Se há uma premissa básica de que toda ética pressupõe uma antropologia filosófica, ela nunca foi tão verdadeira. Sganzerla:

É preciso considerar, portanto, que o autor propõe uma "biologização do ser moral" e não uma "biologização da moral" ou mesmo uma "moralização da natureza". A diferença estaria justamente no fato de que Jonas não retira simplesmente da natureza a moralidade e nem sequer usa a natureza como regra para a moralidade, mas reafirma a pertença do homem (ser moral) ao reino da natureza (numa espécie de ontobiologia) ${ }^{16}$.

\footnotetext{
13 Op.cit. 2006, p.163

${ }^{14} \mathrm{O}$ próprio Jonas nos remete à leitura de Max Scheler. Cf. SCHELER, M. Der Formalismus in der Ethik und die Materiale Wertethik: Neuer verluch der Grundlegung eines ethischen Personalismus. [Freiburg?]: Max Niemeyer verlag, $1916<$ Disponível em

https://archive.org/stream/DerFormalismusInDerEthikUndDieMaterialeWertethik/Max Scheler Der Formalism us in der Ethik\#page/n1/mode/2up acessado em 30 agosto 2016>

15 Op.Cit. 2006, Capítulo IV O Ber, O Dever, O Ser: Teoria da Responsabilidade.

16 SGANZERLA, Anor. Biologização do ser moral em Hans Jonas. Revista de Filosofia Aurora. Curitiba, V.25, n.36, p.155-178, jan./jun.2013 <Disponível em file:///C:/Users/181/Downloads/rf-7769.pdf acessado em 06 julho 2016>, p.160-161
} 
Manter distante a moral e a vida a não confundi-los permite que estejamos seguros de que Jonas escapou de algumas falácias, entre elas a falácia naturalista, elucidada por Hume, que estabelecia uma impossibilidade de se passar da ontologia para a axiologia, devido à natureza diferentes do objeto ontológico e moral, respectivamente. A falácia naturalista é caso para discussão, e não podemos nos esquivar dela no itinerário de nossa pesquisa. Prossigamos:

Note-se que estamos interessados no conceito de natureza em função da doutrina da finalidade, e não ao contrário; não nos interessamos pelo conceito de finalidade em função da doutrina da natureza. Queremos - em última análise, em função da ética - ampliar o lugar ontológico da finalidade como um todo $(. . .)^{17}$

A nossa questão aqui é buscar compreender em que momento começa a metafísica e em que momento começa a ética. Textualmente ela é visível, porém, justamente em face de sua exigência, a de um imperativo “ontológico", não sabemos de que modo estabelecer uma fronteira entre o ético e o metafísico, se é que assim podemos proceder. Vimos acima que a biologização do ser moral não pode se confundir com a biologização da moral - algo que salva Jonas de um estoicismo, perguntamo-nos - pois o encargo moral não cabe à natureza, nem uma moralização da natureza, pois a moral é peculiar ao homem. Mas isso não quer dizer que a ética se aparte da metafísica ou vice-versa. Aliás, podemos dizer com segurança o contrário, de que para Jonas o que falta à ética é justamente metafísica, e ao estabelecer a teoria da Responsabilidade, ele o faz em favor da inerência entre o que é ético e o que é metafísico: "Através da imanência dos fins no Ser, a batalha decisiva pela teoria da ética já havia sido ganha"18.

Princípio Responsabilidade quer dizer justamente sobre a inerência que há entre o ético e o metafísico. Devemos perguntar afinal: que metafísica é essa que gera a ética da responsabilidade? O procedimento jonasiano não adere à responsabilidade como matéria prima para um princípio ("da” Responsabilidade) ${ }^{19}$, assim como à Vida. São dois princípios inerentes, a responsabilidade é o princípio; a vida é o princípio $^{20}$ !!

\footnotetext{
17 Op.Cit.2006, p.136

18 Op.Cit. 2006, p.146

${ }^{19}$ É o que eu explico em meu único artigo publicado sobre o autor: "O nome deste ensaio e, portanto, o nome dessa ética para esta tal civilização tecnológica clama por uma responsabilidade e a clama de uma maneira que precisaremos refletir. Por que Princípio Responsabilidade e não meramente e usualmente Princípio da Responsabilidade? Entre o uso e o não uso da preposição é possível notar uma concepção do tema proposto. Vejamos: Se disséssemos da Responsabilidade a preposição conferiria ao termo antecedente a preponderância que rege a relação e a conexão deste com o outro termo. De tal modo que se disséssemos que o ensaio propõe um Princípio da Responsabilidade estaríamos supondo que há aí uma ética que busca refletir sobre a responsabilidade e retirar daí um princípio possível, talvez aplicável. Aplicável ao que? À Civilização tecnológica? A responsabilidade seria, portanto, uma matéria prima cuja ética vem a dar validade, ao formata-la na qualidade de um princípio? (...) Isto não se sustentaria: Princípio Responsabilidade quer dizer, sobretudo, que a Responsabilidade é o Princípio.” (BRAZIL, 2016, p.125-126)

${ }^{20}$ Cabe lembrar que a obra traduzida para o português como "Princípio Vida" possui no original em inglês um título diverso, mais facilmente traduzível não como "Princípio", mas sim "Fenômeno": The Phenomenon of Life.
} 
Entre o Princípio Vida e o Princípio Responsabilidade o que testemunhamos é que, uma vez descentralizado o homem em relação à natureza através de uma reinterpretação da vida e da subjetividade, temos por outro lado a localização da Responsabilidade no homem como aquele que detém o dom de agir em função do todo, não apenas no imediato do tempo e do espaço. Se, através da tradição, nós podíamos afirmar, sem muito embaraço, dois territórios distintos e com fronteiras bem definidas, de um lado o terreno da ontologia, cuja meta de seu saber era desvelar a necessidade, e de outro lado o terreno da ética, cuja preocupação principal se ocupava em estabelecer a liberdade, agora, sem os muros que dividiam o terreno temos que dar conta da liberdade e da necessidade sem sermos seduzidos pelo dualismo oposicionista. Em verdade, é justamente a liberdade o que redimensiona a ética da Responsabilidade no todo da vida, pois cada vivente já manifesta liberdade ${ }^{21}$. O entendimento do lugar da ética e do lugar da metafisica diante deste todo reconfigurado é o nosso propósito.

A nossa questão aqui é entender a) como se dá a passagem que vai da metafísica para a ética e b) como se sustenta essa relação. As indicações para ambos os propósitos aparecem ao longo de todo O Princípio Responsabilidade.

Pelo fato de o objeto ético ser de uma natureza inteiramente distinta do objeto da ética tradicional, é de se esperar que a metafísica de onde ela parte, ou ao menos o modo como essa relação entre ética e metafísica se dá, seja de um teor inteiramente distinto também. É nesse ponto que a pesquisa pretende se concentrar. Como teremos a chance de ver, ocupa um lugar central na teoria da responsabilidade um certo "sentimento" de responsabilidade ${ }^{22}$, sentimento esse ligado a um estado de coisas objetivo e não meramente oriundo da homologia entre razão e vontade. Esse sentimento deriva das coisas, do ser temporal e o cuidado que este requer: "à luz dessa amplidão transcendente, torna-se evidente que a responsabilidade não é nada mais do que o complemento moral para a constituição ontológica do nosso ser temporal"23 (JONAS, 2006, p.187).

Diante de um estado de coisas como colocado na citação acima, como não tratar a responsabilidade como um epifenômeno? Qual a razão de ficarmos com o "complemente moral" se podemos ficar com o ser mesmo?

\footnotetext{
21 Op.Cit. 2008, p.86

22 Wendel Evangelista esmiúça que há um plano objetivo de fundamentação da metafísica de Jonas a partir de dois esforços centrais, um de caráter lógico metafísico e outro de caráter ontológico metafísico, sendo esses finalmente complementados por um plano subjetivo, o "intuicionismo". Cf: EVANGELISTA, Wendel. A Fundamentação Metafísica do Princípio Responsabilidade em Hans Jonas. 2008. 140 f. Dissertação (Mestrado em Filosofia) - Faculdade Jesuíta de Filosofia e Teologia, Belo Horizonte. $\quad$ Disponível em http://www.faculdadejesuita.edu.br/documentos/180915-K9SrJvvkVEd.pdf acessado em 05 julho 2016>. 23 Op.Cit. 2006, p.187
} 
Essas perguntas são, evidentemente, retóricas. É claro que Jonas se protegeu dessa falácia e também de outras possíveis. É que embora a teoria da responsabilidade seja bastante consistente, ela não está a salvo de problemas e dúvidas. Que tipo de relação pode haver entre ética e metafísica? Que tipos de relação existiram tradicionalmente? A proposta metafísica da ética da responsabilidade é uma resposta não apenas ao apelo do mundo contemporâneo, mas, também, às éticas contemporâneas? Jonas dialoga com essas éticas? Como é possível falar em dever depois de Nietzsche ter publicado "A Genealogia da Moral”? Como é possível uma ética metafisicamente fundada na conjuntura da filosofia contemporânea?

O ponto central da posição filosófica de Jonas é contundente: há um agir na natureza. Essa tese contraria todo tipo de posicionamento determinista e mecanicista do mundo natural. Ao se repensar este, é o lugar que o homem ocupa diante dele que também se modifica incisivamente: "isso implica que a eficiência dos fins não está exclusivamente vinculada à racionalidade, reflexão, livre escolha - portanto, ao homem"24.

Se verificarmos o ambiente das reflexões éticas do mundo contemporâneo, constataremos que boa parte das discussões derivam daquele esvaziamento dos sistemas metafísicos presentes na filosofia desde o século XIX. Não temos condições de fazer nenhum tipo de afirmação conclusiva, mas seria de se verificar que a emergência de uma pluralidade de discussões no âmbito da ética, e também da política, no mundo contemporâneo, parece ter uma consequência deste suposto fim da metafísica. E de fato parece haver uma urgência da ética, e os pensadores parecem não poder esperar mais por uma metafísica que sirva de fundamento para o mundo contemporâneo. Essa relação entre ética e metafísica interessa-nos aqui, pois acreditamos que Jonas encontre uma base de contribuição importante para essa discussão. A pergunta que se relaciona com esse problema é: há afinal um primado da ética, um primado metafisico ou não se

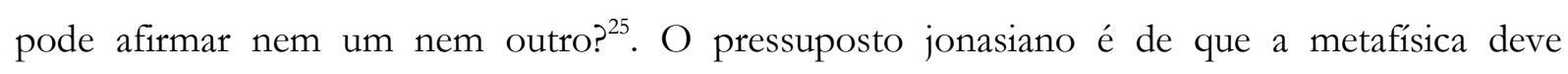
sustentar a ética. Em todo caso, é muito importante nos atentarmos como se dá essa relação, pois ela não parece acontecer de uma maneira usual, há algo inédito e interessante neste Princípio Responsabilidade.

O elementar do posicionamento jonasiano está no lugar que a finalidade ocupa no todo da vida. Mas não apenas se trata de atribuir fins meramente, pois o lugar da causa eficiente também é interpretado, e é isso o que permite a Jonas dar à liberdade um estatuto natural, pois ela está ligada ao fenômeno da vida e ao orgânico. De todo modo, ainda que esse seja um capítulo inteiramente à parte com relação à passagem da metafísica para a ética é preciso deixara claro o argumento de Jonas que parte da doutrina dos fins em direção à doutrina do valor. A

\footnotetext{
${ }^{24}$ Id.Ib., p.127-128

25 Op.Cit. 2008, p.45-46
} 
questão de Jonas é mostrar que fins imanentes reproduzem valores imanentes. Há um deslocamento de perspectivas que permite o autor de interpretar a partir do "ponto de vista da coisa" um fim imanente a si mesmo e a partir desse, um julgamento de valor de acordo com o próprio telos do objeto. Soa como Aristóteles, e de fato há autores que atribuem a Jonas um aristotelismo, algo de que não temos ainda condição de afirmar e que se revelará à medida que buscarmos as respostas de nossas principais questões. Mas, dizíamos, a finalidade imanente de determinada coisa é seu próprio valor: finalidade em si mesma e valor em si mesmo coincidem ${ }^{26}$. Esse parece ser o primeiro passo necessário em direção à ética da responsabilidade. Ou, como disse Hottois (1993) apud Evangelista (2008): a deontologia se revela no coração da ontologia. Jonas: "o homem não tem nenhuma outra vantagem em relação aos outros seres viventes, exceto a de que só ele também pode assumir a responsabilidade de garantir os fins próprios aos demais $\operatorname{seres}^{27,}$.

Ainda sem resultados prévios, porém à guisa de conclusão para este projeto, optamos por não denominarmos esta pesquisa de "A Inerência entre ética e metafísica", uma vez que o objeto de análise é menos a inerência entre as duas disciplinas filosóficas do que o espaço entre ambas. Pensamos também em outro título: "A confluência entre ética e metafísica", porém o termo não elucidava o conteúdo da preocupação, e parecia a mesma ideia do título anterior, pois aquilo que conflui de certo modo possui relação inerente. De maneira que optamos por "Entre a Ética e a Metafísica: a Fundamentação ontológica da Responsabilidade", pois sintetiza de modo geral a intenção de nossa pesquisa, que procura entender o lugar de cada uma dessas duas disciplinas filosóficas e sua relação no pensamento de Hans Jonas. Para a atual publicação, pensei em Os Caminhos Cruzados entre ética e metafísica, para manter essa ênfase que distingue o ético e o metafísico, dois caminhos em cruzamento.

\footnotetext{
${ }^{26}$ Id.Ib., p.61

27 Op.Cit.2006, p.175
} 


\section{REFERÊNCIAS}

JONAS, Hans. O Princípio Responsabilidade: ensaio de uma Ética para a civilização tecnológica. Tradução de Marijane Lisboa e Luiz Barros Montez. Rio de Janeiro: Contraponto: ed. PUC-RJ, 2006.

BRAZIL, Luciano Gomes. Consideraçoes Acerca do Princípio Responsabilidade de Hans Jonas in: VILAS BÔAS, João Paulo Simões; FAHRI NETO, Leon; PERIUS, Oneide (Org.). Filosofia em Debate: Questões de ética, educação e política. Florianópolis: Nefiponline, 2016. P.125$148<$ Disponível em http://www.nefipo.ufsc.br/files/2012/11/Quest \%C3\%B5esV3.pdf acessado em 30 agosto $2016>$

EVANGELISTA, Wendel. A Fundamentação Metafísica do Princípio Responsabilidade em Hans Jonas. 2008. 140 f. Dissertação (Mestrado em Filosofia) - Faculdade Jesuíta de Filosofia e Teologia, Belo Horizonte. <Disponível em http://www.faculdadejesuita.edu.br/documentos/180915K9SrJvvkVEd.pdf acessado em 05 julho 2016>.

GADAMER, Hans-Georg. A Ideia do Bem entre Platão e Aristóteles. Tradução de Tito Lívio Cruz Romão. São Paulo: editora Martins Fontes, 2009.

HEIDEGGER, Martin. A questão da técnica in Ensaios e Conferências. Tradução de Emmanuel Carneiro Leão. Petrópolis: Vozes, 2010. P.11-38 (Coleção Pensamento Humano).

KANT, Immanuel. Fundamentação da Metafísica dos Costumes. Tradução, introdução e notas de Guido Antônio de Almeida. São Paulo: Discurso Editorial: Barcarolla, 2009 (Coleções Philosophia)

SCHELER, Max. A Posição do Homem no Cosmos. Tradução e Apresentação de Marco Antônio Casanova. Rio de Janeiro: Forense Universitária, 2003.

SGANZERLA, Anor. Biologização do ser moral em Hans Jonas. Revista de Filosofia Aurora. Curitiba, V.25, n.36, p.155-178, jan./jun.2013 <Disponível em file://C:/Users/181/Downloads/rf-7769.pdf acessado em 06 julho 2016> 


\section{POSSÍVEL CONTRIBUIÇÃO DA PRAXIS AO DESAFIO DA ECOLOGIA}

A possible contribution of praxis to the ecology challenge

\section{Maria do Carmo Bettencourt de Faria ${ }^{1}$ \\ Doutora em Filosofia}

RESUMO: Pretendemos aqui enfrentar, na medida do possível, três questões que emergem na marcha do pensamento ocidental: a concepção da natureza que manifesta em si uma ordem harmônica e inteligível, diante da qual só é possível a atitude de admiração contemplativa própria da antiguidade, que se perde na modernidade. A lógica linear cartesiana e sua ambição de dominar a natureza fazendo do homem um ser doente de sua racionalidade, marca da modernidade. A busca por uma saída para o beco em que se encontra a humanidade e que exige a difícil senão impossível harmonização da tecnologia e da economia com a ecologia, recolhida por uma ética ainda a construir - desafio a que se lançou H Jonas. Aubenque nos oferece uma pista ao propor o resgate da ética aristotélica. A grande contribuição desta 'aretologia' residiria no conceito de 'prudência' (phronesis), mas queremos ampliar este resgate e propor uma reflexão sobre o que representa o outro paradigma que Aristóteles desenha ao lidar com a complexidade da práxis. Se a devastação da terra evidencia o esgotamento do modelo da ciência/tecnologia herdeiro da Metafísica e de sua lógica imanente, a exploração deste outro paradigma que lida com a complexidade do contexto abrindo espaço para a emoção e o desejo, e que sabe que só pode, quando muito tangenciar a verdade, merece, no mínimo, um momento de nossa reflexão.

PALAVRAS-CHAVE: Hans Jonas; Aristóteles; Práxis.

${ }^{1}$ Conferência apresentada II Seminário Hans Jonas da UFRJ - 7a 9 de dezembro de 2016 - Rio de Janeiro, IFCS 
"E com o homem, é o mundo inteiro que se arruína e se torna doente, é a vida na sua totalidade que é depreciada"

(in Deleure : Nietzsche)

Tomo aqui, como ponto de partida, os dois textos abaixo:

É esta a situação do ser humano. Foi-se o Cosmos com cujo Logos imanente meu logos podia sentir-se aparentado; foi-se a ordem do todo, onde existe um lugar para o ser humano. Este lugar aparece agora como puro e incompreensível acaso $^{2}$

Nessas condições, eu me pergunto se um retorno ao pensamento grego não poderia nos proporcionar elementos de solução e se a invenção aretológica ${ }^{3}$ requerida pelos desafios modernos da técnica não deveria consistir, ao menos num primeiro momento, em reatualizar um modelo aretológico antigo que não por acaso - foi expressamente rejeitado pela moral kantiana: penso na virtude aristotélica da phronesis - prudência. (Klugheit). ${ }^{4}$

No prefácio de sua obra, O Princípio Responsabilidade, H Jonas, face ao imenso poder conquistado pelo Homem graças aos avanços da ciência e da tecnologia, clama por "Uma ética que por meio de freios voluntários, impeça o poder dos homens de se transformar em uma desgraça para eles mesmos".

Neste sentido, ele tanto apela para uma "heurística do medo" como propõe uma recuperação da dimensão metafísica e a retomada "das antigas questões sobre a relação entre ser e dever, causa e finalidade, natureza e valor" e confessa ter consciência de que enfrenta "um objeto extremamente atual com uma filosofia nada atual, quase arcaica"s.

Não estaríamos então tão longe da proposta de Aubenque, de uma retomada do antigo conceito de prudência, analisado por Aristóteles na sua Ética a Nicômaco e que foi rejeitado pela ética kantiana "não por acaso" .

\footnotetext{
${ }^{2}$ Jonas Hans: O Princípio Vida - Fundamentos para uma biologia filosófica, Petrópolis, Vozes, 2004

${ }^{3}$ Arete (gr.) $=$ virtude

${ }^{4}$ Aubenque Pierre: Um modèle aristotélicien pour l'eco-éthique in Problèmes Aristotéliciens, Paris, Vrin,2011. Com seu livro sobre a Prudência em Aristóteles, Aubenque renova a leitura e interpretação da ética de Aristóteles.

${ }_{6}^{5}$ Jonas, Hans O Princípio Responsabilidade, Rio, Contraponto-PUCRio, 2006 - Prefácio.

${ }^{6}$ Idem ibidem

${ }^{7}$ Idem ibidem

${ }^{8}$ Idem ibidem

${ }^{9}$ Aubenque, op. cit. Cf. igualmente La Prudence chez Kant, Revue deMétaphysique et de Morale.
} 
O objetivo do presente trabalho, então, é o de refletir sobre a proposta de Aubenque e, para isto, retomar em grandes linhas a Ética de Aristóteles, sua análise da praxis e seu conceito de prudência; refletir sobre a rejeição desta ética na Idade Moderna que a trocou por uma ética puramente racional que consagra a reciprocidade e por fim, refletir sobre necessidade/possibilidade de recuperação do antigo conceito de prudência, numa ética da responsabilidade.

A Ética aristotélica está estreitamente articulada à sua Metafísica. Deixaremos aqui de lado a questão se devemos ler a Metafísica a partir da Ética ou vice-versa, mas o certo é que, Apesar de Aristóteles sublinhar a distância entre os dois campos, a diferença entre os dois objetos - o Ser e o agir virtuoso; ou o mundo da natureza e o mundo dos homens - e consequentemente a diferença de métodos, as duas esferas são como os dois batentes de uma única janela, ou as duas faces de uma mesma moeda. A imagem das ondas circulares que se formam a partir do choque da pedra com a água, cujo movimento se transmite de uma a outra, ilustra a articulação que pode ser encontrada entre os diversos planos do pensamento de Aristóteles.

Segundo o que nos diz Aristóteles, a Filosofia surge do 'espanto' Tháumazein' diante do maravilhoso. Este espanto pode ser interpretado a partir das palavras de Heráclito: 'Tudo é Um'(hen panta einai). "O Um em si mesmo diverso" (en diapheron eautô $)^{10}$

A descoberta da conexão entre todas as coisas revela o nexo - o 'logos' - que envolve tudo quanto há e que ao mesmo tempo dirige o fluxo eterno do Vir a Ser. Mas este Logos ainda não é 'lógico', não obedece ao princípio da não contradição: claro e escuro, vida e morte, imóvel e mutável, ser e não ser coexistem, se enfrentam e combatem num eterno fluir. E o logos humano deve abrir-se, e 'pensar-com'. O combate entre os opostos, como uma dança, obedece a uma ordem. O Todo é um Kosmos, um todo ordenado, harmonioso, onde se combinam o fluxo e a permanência e onde a identidade permanece na e pela mudança. O mesmo rio, sempre outro. "Harmonia das tensões opostas, como a do arco e da lira"11. Entre a madeira e a corda, a tensão se estabelece e dela surge a harmoniosa melodia, a eficiência do tiro. Laço e combate; justiça e discórdia; tensão e harmonia. A permanência, a imobilidade, a identidade, são momentos fugazes de equilíbrio; precário e instável equilíbrio entre tensões opostas que logo se rompe para se refazer em outra parte. Como não ser tomado pelo espanto diante destes pensamentos? ${ }^{12}$

A essa intuição primeira da Filosofia junta-se outra: a imutável, eterna, única identidade do Ser, proclamada por Parmênides. A razão o exige; entre o Ser e o Nada nenhuma ponte é

\footnotetext{
${ }^{10}$ Kirk e Raven Os Filósofos Pré Socráticos, Lisboa, Fundação Colouste Gulbenkian /1979/ frgs 199 e 206

${ }^{11}$ Kirk e Raven op.cit. Frg 212

12 Não queremos com isso dizer que Heráclito seja a fonte determinante do pensamento aristotélico.
} 
possível - "Nem de Não Ente permitirei que digas e penses; pois não dizível nem pensável é que não é"13

Ao invés de pensar o-que-é-com, (Heráclito) é preciso separar a verdade da aparência, distinguir entre si os dois caminhos, da Verdade e da Opinião: revelação divina, que conduz o homem e o protege da ilusão e do falso. Neste sentido, Heráclito teria se afastado da trilha da Verdade, e, como os "mortais de duas cabeças", trilhado o caminho enganoso da opinião.

A pluralidade, a diferença, o movimento e a mudança não passam de mero jogo de luzes e sombras. A luz que incide sobre a lua, sempre igual, sempre a mesma, faz parecer que ela nasce e morre, cresce e decresce - o mesmo efeito se reproduz em toda parte iludindo os "pobres mortais" ${ }^{\prime 14}$.

Contra a evidência dos sentidos, a frieza do raciocínio lógico - impossível pensar a mistura de ser e não ser. Nega-se então realidade da pluralidade, da mutabilidade, do fluxo, ao mesmo tempo em que se afirma o Ser Único em sua perfeita identidade. "O mesmo que permanece o mesmo e em si repousa" ${ }^{15}$ Bloqueia-se o acesso da Filosofia, submetida a tais exigências lógicas, à concretude, à diversidade e à realidade palpável do instável e inseguro mundo dos homens objeto da mera opinião.

Seja por Heráclito, seja por Parmênides, o paradoxo se instala no âmago do pensamento nascente. O ceticismo espreita ao final do caminho.

A solução dualista proposta por Platão, na tentativa de superar tal paradoxo é descartada por Aristóteles. O mundo ideal de arquétipos perfeitos capaz de oferecer um fundamento seguro à ação dos homens e suas escolhas, é negado. Uma nova Metafísica é requerida que por sua vez, possibilitará o surgimento da ética como esfera autônoma, que deverá encontrar no próprio mundo do homem (ta andrópina), os critérios e a medida da ação virtuosa.

Já muito se disse que Aristóteles permanece platônico em sua Metafísica mas se aproxima dos sofistas no plano da Ética. O próprio Aristóteles assinala a diversidade dos objetos e, como dissemos, a distância, a autonomia, a diversidade de métodos nos dois campos. Mas entre eles um laço, uma ponte, um elo se estabelece: a teleologia.

E essa mesma teleologia, detectada também por Hans Jonas no plano da natureza orgânica e reintroduzida na abordagem científica, permitirá talvez a articulação procurada no escopo deste trabalho. "A tendência [da natureza] a uma finalidade, manifestada em suas realizações (...) deveria estar incluída no conceito de causalidade física." 16 "Em suma, uma

\footnotetext{
13 Idem, frg. 347

${ }^{14}$ CF. Popper K. O Mundo de Parmênides, S Paulo, UNESP, 2014

${ }^{15}$ Kirk e Raven op.cit. frg.350

${ }^{16}$ Jonas, H. O Princípio Vida, Fundamentos para uma biologia filosófica Petrópolis, Vozes, 2004
} 
doutrina da emergência [do novo] só pode ser sustentada, em termos lógicos, em associação com uma ontologia grosso modo aristotélica." ${ }^{17}$

Em sua minuciosa observação da natureza, Aristóteles repete o bordão: “A natureza nada faz em vão" "18: "No início da investigação temos que postular os princípios que invocamos constantemente no uso de nossa investigação científica da natureza que devemos tomar como garantidos em virtude de seu caráter universal que aparece em todos os trabalhos da natureza. Destes, um é que a natureza não cria nada em vão, mas visa o melhor possível em cada espécie dos seres vivos com referência à sua constituição essencial. De acordo com isto se um modo é melhor que outro, esse será o modo da natureza."19

Este princípio, detectado na observação da própria natureza, se estende aos planos ético e metafísico. Por ele podem se articular os diferentes campos da Filosofia apesar da diversidade de seus objetos e dos métodos mais adequados para estudá-los.

Esta tendência de todas as coisas em direção a uma finalidade, aparece no âmbito das 'coisas humanas' na forma de desejo: Assim a ética se abre com a proposição: "Toda arte, toda pesquisa e toda ação tendem para algum bem (...) e por isso se declara com razão que o bem é o que todas as coisas tem em vista" ${ }^{20}$ Da mesma forma a Metafísica afirma em seu primeiro Livro: "Todos os homens desejam por natureza, o saber" 21

$\mathrm{Na}$ Física e na Metafísica, entre as causas que devem ser levadas em conta para que se atinja o conhecimento de um ser, figura a causa final, aquilo em vista do que o movimento se dá; aquilo para o qual tende o ente em sua realização progressiva. Entre as quatro causas (matéria e forma, motor e fim) é o fim que sobre determina as demais causas: não se faz uma serra com barro, não se constrói uma escada se não houver um segundo andar. Tanto a matéria como a forma se determinam em função de uma finalidade que, no plano dos movimentos naturais (dos entes que tem em si o princípio imanente do movimento) é o próprio motor. É a grande novidade apresentada por Aristóteles face aos pensadores que o precederam. O que move em última análise um ser é a finalidade buscada, finalidade que se identificará, com a realização plena de si mesmo, com a plena atualização de suas potências.

Com o binômio potência/ato, articulado às quatro causas, Aristóteles tem em mãos o conceitual teórico necessário à superação do paradoxo posto por Heráclito e Parmênides.

\footnotetext{
${ }^{17}$ Idem, O Princípio Responsabilidade Rio de Janeiro, Contraponto: PUC RJ 2006

${ }^{18} \mathrm{Cf}$, São diversas as passagens em que a mesma constatação é reiterada, tanto na Física como nos pequenos tratados sobre a natureza conhecidos como Parva Naturalia.

${ }^{19}$ Aristóteles The Progression of Animals - The Complete Works of Aristotle Ed. Jonathan Barnes, - EUA

Princeton University Press, 1985

20 Aristóteles, Etica a Nicômaco $1094^{\mathrm{a}} 1$

${ }^{21}$ Idem, Metafísica $980^{\mathrm{a}} 1$
} 
Os entes são em última análise, um projeto de si mesmos; contêm em si, potencialmente tudo o que podem vir a ser no decorrer de sua existência temporal. A forma, potencialmente contida na matéria, dela se apropria progressivamente e tende espontaneamente para sua atualização, desde que encontre as condições necessárias para tal. Seja no plano humano, seja no plano da natureza o ser é o que era para ser. (to ti en einai)

A mesma ordem natural, imutável e eterna se renova continuamente no processo de geração/ corrupção (genesis/phtora) ${ }^{22}$, pois, se o composto é corruptível, o mesmo não se dá com a matéria nem com a forma, eternas. Diante da Physis, cabe ao homem apenas a possibilidade de conhecê-la; de contemplá-la descobrindo suas articulações, suas razões e causas. ${ }^{23}$

Enquanto ser da natureza o homem se inscreve na mesma dinâmica e seria possível pensar aqui uma ética "naturalista" - deixar que a natureza siga seu curso, e o homem tenderá espontaneamente à autorrealização; ao bem. (Rousseau em Aristóteles!) ${ }^{24}$ Aristóteles, no entanto, estabelece uma distinção entre as potências irracionais e as racionais. Se a potencia é sempre potencia de contrários, as primeiras - encontradas em todos os entes da natureza - operam espontaneamente tendendo sempre à realização de um contrário e deixando surgir o outro pela falha, pela não realização (o fogo sempre aquece enquanto o frio só ocorre com a sua ausência). As potencias racionais, ao contrário realizam-se em um ou outro dos dois contrários (o médico que sabe curar sabe também matar) e a realização de um dos contrários exige a deliberação e a escolha. Eé só no ato, que a potência se revela.

Há assim uma diferença fundamental entre o mundo da natureza e o mundo do homem (ta andrópina). Aqui não encontramos mais uma ordem universal, eterna e imutável, mas um tatear dos homens, "animais políticos", em busca da melhor forma de conviver. É o reino da doxa objeto da dialética que, senão permite a demonstração rigorosa a partir de premissas assentadas como verdadeiras, permite ao menos depurar a opinião de suas contradições aproximando-se assim da verdade. Se há aqui uma tendência natural para a verdade e o bem, como indica a primeira proposição da Ética citada acima, essa tendência só se realiza por meio dos atos humanos que dependem da avaliação, da deliberação, da escolha e do desejo.

No campo das ações humanas uma nova diferenciação é estabelecida, que nos interessa aqui particularmente. Elas se dividem por duas esferas distintas: poiésis e práxis: produção e ação -

\footnotetext{
$22 \mathrm{O}$ movimento descontínuo da geração/corrupção só ocorre no âmbito do mundo sublunar e restaura de algum modo a circularidade do movimento celeste, contínuo e eterno.

${ }^{23}$ Aristóteles como em geral, os gregos, ignoram a noção de um tempo linear, trazida pela tradição hebraico cristã. No ciclo, passado e futuro acabam por encontrar-se.

${ }^{24}$ Bettencourt de Faria, Maria do Carmo - Ética do Bem ou Ética da Prudência - Seminário Sênior IFCS/UFRJ, setembro 2013 (inédito)
} 
uma dirigida pela arte (techne) outra, pelos costumes e tradições, (ethos). ${ }^{25}$ Seja no campo da arte, seja no da práxis, as ações decorrerão da atualização de potências inatas, e resultarão em novas potencialidades adquiridas graças a "esforço e exercício".

A arte (techne) corresponde a uma etapa intermediária na conquista do conhecimento científico e se situa entre a experiência (empiria) acumulada pela memória, intransmissível, e que apenas constata o fato, e a ciência (epistheme) que busca o conhecimento através das causas ou razões. Transmissível, desinteressada e inútil, a ciência responde à sede de saber natural do homem.

Como a experiência a arte atua no concreto do fazer, do acontecer, da operacionalidade; como a ciência, precisa articular efeitos e causas, para, agindo como causa/motor, obter o efeito esperado, o fim visado.

A produção (poiésis) orienta-se para um objetivo exterior ao agente: para a produção de uma obra. Segue normas fixas e um encadeamento previsível de causas/efeitos. É um processo linear indiferente ao tempo, ou às relações culturais de um dado grupo. Implica em clareza e rigor nos processos, em previsão dos efeitos possíveis, em normas, medidas e regras. "Imita" a natureza e se deixa transmitir por um adestramento capaz de desenvolver as habilidades do indivíduo, o que explica que escravos possam aprender e se destacar em sua arte como foi o caso, por exemplo, de um Phídias. Os efeitos da arte e sua excelência, se manifestam no produto, na obra realizada. Diz pouco ou nada sobre as qualidades morais do artista. E é na obra realizada que ela se esgota - "não se constrói a casa construída, nem se fecha a porta fechada". A ação recomeça em nova obra, com nova matéria a que se impõe a forma concebida pelo artista. ${ }^{26}$

No entanto, Aristóteles afirma que o modo de vida dos humanos consiste mais propriamente na práxis do que na produção. A práxis pertence ao mundo dos homens, aos seus negócios (ta prágmata) Implica num aprendizado - bem diferente do adestramento da techne, pois pressupõe a liberdade, a capacidade de reflexão, deliberação e escolha. A práxis desenvolve no homem (livre) o que ele tem de mais propriamente humano. Seu efeito, ao contrario da techne, se faz sentir sobre o próprio agente, modifica-o, confere-lhe um caráter, uma "segunda natureza" que indica "quem" ele é. Desenvolve nele novas disposições, novos modos de agir, novas potencialidades, as virtudes. O homem é obra de si mesmo.

O exemplo da voz e da linguagem é aqui emblemático: Aristóteles afirma que, por natureza, nascemos com a voz, mas, ao contrario dos outros animais, devemos aprender a falar

\footnotetext{
${ }^{25}$ Sobre os conceitos de práxis e technê Cf. Bettencourt de Faria Direito e Ética - Aristóteles, Hobbes e Kant S. Paulo, Paulus, 2007

${ }^{26}$ A Idade Moderna é marcadapelo encontro entre a ciência, cultivada nos murso fechados das Universidades e as Oficinas, onde as técnicas eram repassadas de mestre a aprendiz, dando nascimento à tecnologia.
} 
nossa língua: a linguagem é aprendida, e é a posse da linguagem, seu domínio, que faz do homem um "animal político".

A práxis é infinitamente mais complexa que a techne. O homem não nasce pronto: deve fazer-se homem e este aprendizado tem que ser retomado por cada um. Se a práxis implica necessariamente a presença da razão, não significa que pertença ao mesmo campo da ciência teórica. Seu campo é o da doxa, da opinião vigente, dos costumes, tradições e hábitos presentes em dada cultura ${ }^{27}$ - êthos. Ethos ${ }^{28}$ também é o caráter que se forma neste embate do indivíduo com os outros: o homem é um "animal político" que se faz homem em contato com seus semelhantes. Não é o campo da irracionalidade, mas escapa aos processos demonstrativos, e dedutivo analíticos.

A natureza do homem não corresponde a nenhuma "ideia" eterna, universal e necessária, nem se realiza espontaneamente e da mesma forma em todos os homens. Ela se atualiza progressivamente, se encontrar o ambiente favorável; se for para isto estimulada, se encontrar referenciais e modelos que possam lhe servir de guia, e testemunhar a medida justa. E, ao atualizar-se, revela a potência subjacente.

Mas, no mundo do homem são muitos os caminhos para se chegar a uma finalidade visada e a qualidade do fim não se transmite necessariamente aos meios para atingi-lo. Meios ilícitos e injustos podem ser eficientes e eficazes. Existe sempre a possibilidade de discrepância no valor moral dos meios e fins, o que não tem como ocorrer no plano da technê.

Entramos aqui na esfera da ética; saímos do campo da natureza em que os meios estão predefinidos dispensando a mediação da deliberação e escolha.

O mundo do homem, seu habitat, o êthos, é fruto de uma construção em grande parte arbitrária, como são arbitrários os nomes escolhidos para designar os entes deste mundo. Nem todos os homens vivem do mesmo modo, cultivam os mesmos valores, obedecem aos mesmos rituais, seguem os mesmos códigos. De tal forma que "até se acreditaria que só existem por convenção". ${ }^{29}$ Onde então encontrar critérios valorativos objetivos?

No âmbito da ética, s? para balizar a ação virtuosa, reconhecer o homem valoroso? No âmbito da política, como encontrar o fundamento que garante a articulação entre o legal e o justo? Aristóteles reconhece aí uma circularidade incontornável: virtude é a justa medida, aquela

\footnotetext{
${ }^{27}$ Para Platão a ciência não se distingue da opinião verdadeira e a dialética permite a passagem de um plano ao outro, depurando as opiniões e tornando-as mais claras em seus fundamentos. Aristóteles parece afastar-se dele nitidamente neste ponto. Se a dialética permite derrubar as opiniões falsas ela não é suficiente para fundamentar a ciência verdadeira.

${ }^{28}$ Aristóteles vale-se da semelhança entre as duas palavras, que se escrevem de forma diferente no grego, para delimitar o objeto de sua Ética. CF. Lima Vaz, Escritos de Filosofia II, S Paulo, Loyola, 1988.

${ }^{29}$ Aristóteles E.N.1094b15
} 
segundo a qual, o homem virtuoso age; justiça é a dimensão social da virtude; a medida da coragem, meio termo entre a covardia e a temeridade, é dada pelo corajoso.

O homem tem no outro seu espelho. Referências e valores só são encontrados no próprio mundo dos homens, objeto de opinião e onde não se pode nem se deve esperar o rigor da ciência teórica cujo objeto é necessário.

A ética move-se no campo do contingente, da incerteza. A ordem eterna, universal e imutável da natureza oferece, é certo, um balizamento. Quando os limites da forma ou natureza são transgredidos, caímos no patológico, na 'de-formação', no monstruoso.

Porém, ao mesmo tempo, este balizamento é bastante flexível. O conceito de natureza se revela insuficiente para determinar uma ética. Há, no homem, algo que transcende os limites da natureza; algo que depende de sua decisão e escolha. Como Aristóteles afirma, o homem é o pai dos seus atos, tal com é o pai de seus filhos. Citando Eveno, refere-se a uma 'segunda natureza' a ser conquistada pelo homem, para que ele possa, enfim, tornar-se homem em plenitude. Não basta ser dotado de voz para saber falar; não basta ser dotado de "capacidade de julgar, inteligência e razão intuitiva" ${ }^{30}$ para ser filósofo. As potências naturais devem desenvolver-se em disposições habituais (hexis) e estas em atos, para que a natureza humana se complete. Bárbaros são os homens que não desenvolveram em plenitude a natureza humana, tal como o fazem os gregos.

Pois a natureza é um telos, um ponto de chegada, mais que um ponto de partida ${ }^{31}$, é um horizonte, mais que um dado. "Com efeito, dizemos que a natureza é o que cada coisa é ao completar-se sua gênese, por exemplo, a de um homem, de um cavalo, de uma família." 32 Lembrando sempre que é o Ato que revela a Potência. ${ }^{33}$

Para aproximar-se deste telos, deste fim, o homem deve desenvolver suas diversas potencialidades naturais: razão e sensibilidade, logos e pathos, harmonizando intelecto e desejo.

Mas seguir a própria natureza seria deixar-se guiar pela atração do prazer e a repulsa da dor, e neste caso, não conquistamos um ethos que identifique quem nós somos. Ficamos totalmente vulneráveis aos fatores exteriores e seríamos semelhantes a 'camaleões' reagindo a cada momento à situação que se apresenta segundo os parâmetros do prazer e da dor. E não

\footnotetext{
${ }^{30}$ Idem, 1143b 30

${ }^{31}$ Cf Aubenque, Pierre, ‘Aristote était-il communautariste?' in Problèmes Aristotéliciens - Philosophie

Pratique Paris, Vrin, 2011

32 Aristóteles, Política 1252b 30

${ }^{33}$ Nos seres compostos do 'mundo sub lunar' - imperfeitos - o ato não chega nunca a esgotar a potência. Apenas

Deus é puro Ato sem potência.
} 
seríamos em nada diferentes dos animais, pois nos distinguimos dos outros animais justamente pela consciência do que é justo ou injusto ${ }^{34}$

A natureza complexa do homem, tantas vezes assinalada por Aristóteles, impede que ela seja tomada como critério ético. O ergon próprio do homem é a atividade conforme a razão ${ }^{35}$, ou seja, aquela que não se deixa determinar apenas pelo impulso ou pelas tendências naturais, mas por virtude, pela decisão refletida. Mas, mesmo assim, como por exemplo, no caso do devasso (akolastós) ou mesmo no caso da habilidade (deinotes) a racionalidade não é o único critério pois não é necessariamente dirigida intencionalmente ao Bem. Um criminoso pode agir racionalmente e, em função de deliberação e escolha atingir o fim (mau) a que se propõe. É preciso, portanto, que o logos seja um orthos logos. Uma qualificação moral da própria racionalidade que articula meios e fins.

“Assim, portanto, não é por natureza nem contra a natureza que as virtudes nascem em nós, mas a natureza nos deu a capacidade de recebê-las e esta capacidade amadurece pelo hábito" 36

Vê-se então o papel fundamental desenvolvido pela prudência (phronesis) que é o elo entre as virtudes morais, virtudes do caráter, cuja matéria é o pathos, e a razão. A prudência é uma virtude do intelecto, mas do intelecto prático, aquele que dirige a ação no concreto. É a capacidade de escolher os melhores meios para chegar aos melhores objetivos. É mais que habilidade, embora não a dispense, pois não é indiferente ao fim. Como, no âmbito da práxis, a menor distância entre a intenção e o ato raramente é uma reta, a prudência guia o homem no labirinto da vida para que ele alcance o bem universalmente visado, a endaimonia. Neste 'tatear' encontra apoio nas referências, nos exemplos, nas tradições e valores; na doxa vigente, devidamente submetida ao processo crítico da dialética.

O homem tem a capacidade de conquistar o que não lhe foi conferido pela própria natureza. É Prometeu, roubando o fogo sagrado e conquistando um poder inédito. E este poder hoje, torna-se uma ameaça, como alerta Jonas, pois “tudo isto se transformou de forma decisiva. A técnica moderna introduziu ações de uma ordem de grandeza tão inédita, com objetos e consequências tão inéditos que o quadro da ética anterior não pode mais contê-los",37. O agir coletivo assumiu tal amplitude que impõe à ética uma nova dimensão da responsabilidade, antes inconcebível. Fica aqui a questão: A atualização deste poder não estaria revelando o potencial

\footnotetext{
34idem, 1253 a 15

35 Idem. E.N.1099 15

36 idem, E.N. 1103 a 25

${ }^{37}$ Jonas Hans, O Princípio Responsabilidade, Rio, Contraponto-PUCRio, 2006
} 
humano muito além do jamais previsto? Não teremos aqui que repensar o que é propriamente o Homem?

Antes mesmo que a questão tivesse assumido a atual dimensão, a ética de Aristóteles já havia sido literalmente solapada em seus alicerces.

O fim da cristandade com a Reforma, aliada à crise da Escolástica; o advento do novo método científico com Bacon, Copérnico e Galileu; o advento do Sujeito, com o cogito cartesiano; a busca de novo método para a Filosofia que alcançasse a certeza e demonstrasse rigor, com Hobbes e Descartes; a contestação do geocentrismo, e a descoberta do Novo Mundo, enfim, marcam o fim de uma era em que a autoridade de Aristóteles ("O Filósofo") se impunha de forma inconteste (tanto na Física como na Ética).

Hobbes traça um novo retrato do ser humano, não baseado numa Metafísica mas na experiência concreta, substituindo o "animal político" aristotélico pelo "homem lobo do homem" cujo fim último é a sobrevivência a qualquer custo; que vê no outro uma ameaça potencial e tem, nas paixões, a força que o comanda. Inútil buscar controlar as paixões com a razão: as paixões só cedem a uma paixão maior e o medo toma então o lugar da philia aristotélica - a solidariedade daqueles que se sabem unidos por um destino comum.

Bacon critica o conhecimento puramente teórico, contemplativo e inútil da antiga Metafísica e estabelece um novo objetivo para a ciência exclusivamente baseada na experiência e na observação controlada: dominar a natureza e colocá-la a serviço das intenções humanas. Seu método visa libertar a humanidade dos "ídolos" da tribo (da raça humana, da superstição), da caverna (a subjetividade), do foro (a comunicação) e do teatro (os falsos sistemas filosóficos) e das noções falsas que obscurecem o intelecto humano.

Descartes delineou o novo Método para a Filosofia: desconstruir para reconstruir com rigor e sobre novo fundamento, o cogito. Passar do complexo ao simples, do obscuro ao claro, do confuso ao distinto; só obedecendo aos critérios imanentes da evidência e da clareza que alicerçam as certezas será possível alcançar A Verdade.

Com seu método, propôs-se delinear uma nova moral, mas ficou apenas na promessa.

Kant, enfim, propõe a Moral da idade moderna. A Moral ditada exclusivamente pela Razão e que não obedece a outra motivação senão o estrito cumprimento do dever.

Descartes reintroduz o dualismo com a rigorosa separação entre a substância pensante e a substância extensa. Desta última é retirada toda dimensão teleológica - ideia confusa e obscura, impossível de ser detectada seja pelo rigoroso método matemático seja pela experiência estritamente controlada e medida. Os novos métodos da ciência nascente e da Filosofia são cegos para a teleologia. Só as causas mecânicas passíveis de medida, previsão e cálculo, importam. 
Essa natureza regida por uma mecânica cega não oferece mais o quadro capaz de oferecer parâmetros ao comportamento. $\mathrm{O}$ abismo entre o mundo da natureza, objeto das ciências 'positivas' e o mundo do homem (mundo da cultura, do pensamento, da subjetividade) se aprofunda de tal forma que desaparece o elo entre fato e valor, entre Ser e dever ser.

A práxis é assimilada à techne; a opinião (doxa) não pode mais ser tomada como fonte do conhecimento, sabedoria ancestral portadora de uma verdade a ser melhor explicitada. É expulsa do campo da ciência por falta de rigor, e igualmente do campo da Filosofia: "Aquilo que até hoje foi escrito pelos filósofos morais em nada avançou no conhecimento da verdade (...) entre os autores daquela parte da Filosofia nunca houve um que adotasse um princípio adequado para tratá-la" ${ }^{38}$ Quando muito pode ser tomada como objeto de estudo de uma antropologia ou de uma psicologia.

A Ética aristotélica é considerada confusa, pouco rigorosa - "Não existe fim último nem summum bonum de que se fala nos livros dos antigos filósofos morais" ${ }^{39}$; Aristóteles é chamado por Bacon de "pior dos sofistas"; Descartes, como depois dele, Kant, apostam, contra Aristóteles, na possibilidade de isolar a razão das paixões e de decidir apenas segundo o que a primeira determina. A moral tradicional para o mesmo Kant, limitou-se a formular "leis indulgentes que fazem concessões às fraquezas humanas". A busca da felicidade, objetivo último da ética aristotélica, não pode fundamentar leis universais por estar marcada pela subjetividade. E "A natureza e a inclinação não podem dar leis à liberdade". ${ }^{40}$

A Retórica, arma capaz de conseguir a adesão por meio da argumentação, concebida "como lógica dos juízos de valor" ${ }^{41}$ é desvalorizada como lógica do meramente aparente, sofística. (E será recuperada de forma bastarda pelo ‘marketing' político ou comercial.) “A partir do momento em que se acredita que a razão, a experiência ou a revelação podem resolver todos os problemas (...) a retórica fica reduzida a um conjunto de procedimentos para enganar os ignorantes" 42

O espaço da praxis, é o da complexidade e da incerteza, e demanda a deliberação e a escolha. Espaço em que se move o homem com todas as suas vulnerabilidades, onde a retórica desempenha um papel central na conquista de adesões. Encontra referência nas tradições e costumes, nos exemplos e na cultura, lida com o imponderável, com a complexidade das causas e motivações de toda ordem, tanto psicológicas e subjetivas quanto políticas, financeiras, culturais,

\footnotetext{
${ }^{38}$ Hobbes, Do Cidadão, S Paulo, Ed. Martins Fontes, 2002- Epístola Dedicatória

${ }^{39}$ Idem, Leviatã, S Paulo, Abril Cutural -Col. Os Pensadores, 1974 - cap XI

${ }^{40}$ Kant, I. En torno al tópico: Talvez eso sea correcto en teoria, pero no sirve para la prática in Ensayos sobre la paz, el progreso y el ideal cosmopolita, Madrid, Cátedra, 2005.

${ }^{41}$ Perelman, Chaim e Olbrechts-Tyteca, Lucie NouvelleRéthorique: Logique et Réthorique in Lempereur, Alain, L'Homme et la Réthorique, Paris, Méridiens Klinksieck, 1990

42 Idem ibidem
} 
históricas e geográficas. A clareza, a nitidez e o rigor são inalcançáveis em muitos pontos; o confuso é irredutível. Como diz Aristóteles, podemos apenas pretender acertar "em grandes linhas"; "tatear" em busca do melhor; "tangenciar" a verdade.

Para o pensamento moderno, por sua vez, o recurso aos costumes e tradições, ao ethos, "obriga o homem a confiar na opinião e na autoridade alheias" como assinala Kant, ou constitui a prisão sem grades de Rousseau.

A lógica linear cartesiana ou a experimentação que delimita um campo e visa isolar a causa e calcular o efeito não conseguem dar conta da complexidade do real que demanda uma abordagem em rede, uma rede semelhante à rede neuronal, plástica, flexível capaz de ampliar seu olhar dirigido pela prudência, para lidar com a complexidade sem reduzi-la ou amputá-la.

A prudência, a virtude "humana por excelência" 44 que exercia um papel central na ética aristotélica estabelecendo a ligação entre a objetividade do intelecto e a subjetividade das paixões, guiando o homem em seu "tatear" em busca dos melhores meios para chegar aos seus fins, é reduzida a simples acúmulo da experiência vivida por cada um. Portanto relativizada, válida apenas no âmbito da subjetividade. ${ }^{45}$

A nova ética que se desenha na Idade moderna consagra o princípio da reciprocidade, designado como "Regra de Ouro" da moral: "Não faças aos outros o que não queres que te façam” um princípio racional, imanente, pragmático, que permite estabelecer os limites a serem observados pelos homens para que a situação de "guerra de todos contra todos" seja evitada

Para Hobbes, o ideal abstrato da virtude e da felicidade cede de fato seu lugar à luta concreta pela auto preservação: a grande questão não é mais, "como agir para tornar-se virtuoso?” mas “como agir para garantir a própria sobrevivência e segurança?” A Política não está mais a serviço da justiça, mas da paz compreendida apenas como a ausência, controle ou repressão da violência natural. E, para conseguir mantê-la sustenta-se em "terrível poder" capaz de inspirar o medo, única paixão que pode colocar um freio às demais. ${ }^{47}$

A moral Kantiana, enfim, consagra a universalidade da Razão Prática e a obediência ao dever, ditado por esta mesma razão, como o único critério que respeita a autonomia a que faz jus o ser humano. A Razão capaz de dirigir o comportamento através de um 'imperativo' imune aos afetos, desejos e paixões (à subjetividade, portanto) oferece o fundamento necessário para alicerçar a ética da autonomia do sujeito, o que lhe confere a dignidade de ser sempre um fim em

\footnotetext{
43 Idem ibidem

44 Aubenque, Pierre La Prudence chez Aristote, Paris, PUF 1997

${ }^{45}$ A Prudencia aristotélica não se identifica ao Princípio Precaução: é assertiva, afirmativa; é a busca da melhor alternativa possível.

${ }^{46}$ Encontramos referência à Regra de Ouro tanto em Locke, como em Hobbes e mesmo em Kant, como uma das fórmulas do Imperativo Categórico.

${ }^{47}$ CF. Bettencourt de Faria Direito e Ética - Aristóteles Hobbes e Kant S.Paulo, Paulus, 2007
} 
si mesmo, nunca um meio ou um objeto. "A razão pura é por si mesma prática, facultando ao homem uma lei universal que denominamos lei moral." 48 O homem que se deixa mover pelo desejo é movido por algo que não lhe pertence - o objeto do seu desejo. Fica, portanto numa situação de heteronomia. O comportamento regido pela prudência também não escapa desta heteronomia: submete-se à situação, às circunstâncias; obedece ao interesse, subordina-se a fins. Só o homem movido pela consciência do dever ditado pela própria razão age por si mesmo, de forma autônoma, isto é, livre. A prudência é excluída do campo da moralidade, reduzida a um 'imperativo hipotético e pragmático’.

A Moral e o Direito vigoram apenas no mundo do homem, regulam as relações entre eles, as máximas, normas e leis que se impõem igualmente a todos preservando a autonomia e liberdade de cada um, compatibilizando entre si as diversas liberdades. A Moral fica restrita ao que Kant designa como foro interno enquanto o Direito atua no foro externo. Ambos encontram seu fundamento/justificação na Liberdade e, portanto, na igualdade de todos perante a lei. As restrições à liberdade só poderiam ser legitimadas pela necessidade de preservar para todos, a mesma liberdade.

Ora, quando não está em jogo outra liberdade - como, por exemplo, na relação homem/ natureza - este princípio da moral kantiana não vigora.

Da mesma forma, Kant afirma que os direitos são correlativos aos deveres e só são conhecidos a partir deles. Logo, onde não há deveres, não se pode também falar em direitos. Essa reciprocidade, característica marcante das éticas modernas, desaparece nas relações entre o homem e a natureza; entre a geração atual e as gerações futuras; como entre o adulto e a criança ou, como assinala Jonas, entre os pais e o recém-nascido. E neste vácuo deve introduzir-se o novo princípio responsabilidade.

A Ética de Aristóteles também supõe o mundo do homem; regula as relações entre eles, com vistas a uma convivência justa, que abra espaço e ofereça as condições para que o homem conquiste a felicidade ao seu alcance. As referências, critérios e valores, são também inerentes ao mundo do homem. As relações homem/natureza não podem sequer aparecer como objeto de questionamento: o homem nada pode diante da ordem natural, eterna e imutável, capaz de renovar-se, superando e compensando possíveis falhas e desvios. Diante da natureza, restam ao homem a contemplação, a curiosidade, e a imitação. A natureza é a grande mestra; o homem, com suas artes, tenta imitá-la em sua sabedoria imanente mas nunca, por impossível, dominá-la.

Compreende-se assim a dificuldade reconhecida por Jonas, de enfrentar os desafios atuais valendo-se de filosofias ou éticas elaboradas em outra época, em outro contexto e em vista de

\footnotetext{
${ }^{48}$ Kant, I. Crítica da Razão Prática, Rio de Janeiro, Ediouro, s/d.
} 
outras problemáticas. Impossível retornar simplesmente a Aristóteles: tanto o conceito de physis como o conceito de ethos foram profundamente alterados. Impossível estender o imperativo kantiano às relações dissimétricas do homem com a natureza, ou da geração atual com a geração futura nem podemos invocar a equidade aristotélica, essa "justiça acima da justiça" - reduzida por Kant a "divindade silenciosa que não pode ser ouvida".

A "heurística do medo" diante da ameaça real à sobrevivência do planeta nos devolve a Hobbes: só o medo atua como freio das paixões humanas. Este medo, que para Hobbes, era imposto pelo poder absoluto do Leviatã, decorre hoje das ameaças reais, das conseqüências nefastas que se anunciam no horizonte, caso uma nova ética não consiga encontrar os meios de frear essa verdadeira 'marcha da insensatez'.

A diferença entre o medo e a prudência está em que o primeiro se move no âmbito do pathos, da vulnerabilidade humana que se deixa afetar pelo mundo exterior, pelos atos, sentimentos e até pelo olhar do outro. A segunda mobiliza as potencias racionais: a capacidade de refletir, de pesar, de medir e comparar. Serve-se e precisa da ciência teórica, do conhecimento objetivo para ter clareza quanto aos fins e aos meios disponíveis para atingi-los. Faz a ponte entre o ser e o dever ser, entre o fato e o valor, entre a ciência teórica e a sabedoria prática.

E o medo deve suscitar o desenvolvimento da prudência.

Apesar de sua articulação com a ciência teórica, em virtude de ser uma virtude "da parte da alma que possui o intelecto", a prudência, ao dirigir a ação, se conecta ao tempo e ao lugar, à ocasião, às relações e forças em jogo, para encontrar o melhor caminho; vale-se da opinião, das tradições, da retórica mas não dispensa as virtudes morais. "Se não há prudência sem virtude moral também não há virtude moral efetiva sem prudência" ${ }^{39}$ É a virtude que falta a Dom Quixote.

Aristóteles faz questão de assinalar que a prudência é mais do que um simples acúmulo de experiências vividas, assim como se distingue da habilidade e da esperteza, embora não as dispense.

A prudência (phronesis) é a virtude que nos permite atingir o maior bem ao nosso alcance em dado momento. Não há como compreende-la se não tivermos em vista o Bem como fim visado.

Esse Bem não é uma ideia (seja no sentido platônico, seja no sentido kantiano) mas telos, termo da ação, plenitude possível, horizonte à distância a nos invocar (o que era para ser - to tí em einai) $)^{50}$ "A natureza nada faz em vão"; "A natureza nada faz contra a natureza”. A natureza não é um dado, é um telos, e não é fruto de um acaso cego, mas de uma finalidade visada. É motor por

\footnotetext{
${ }^{49}$ Aubenque, La Prudence chez Kant op. Cit.

${ }^{50}$ Cf Bettencourt de Faria op.cit.
} 
ser fim. Tende a realizar-se; tende a renovar-se para preservar-se. E, como mostra Jonas, tem direito a ser o que é, a continuar existindo e, portanto, a renovar-se e reproduzir-se.

Ouçamos Jonas: “...uma vez que a matéria manifestou-se desta forma, isto é, que ela efetivamente organizou-se desta maneira e chegou a estes resultados, o pensamento não pode deixar de fazer-lhe justiça reconhecendo a possibilidade de que o que ela chegou a realizar está depositado em sua natureza primitiva" ${ }^{, 51}$

A evolução das espécies ignorada por Aristóteles, altera profundamente a visão da Physis eterna e imutável em seu processo de renovação. O futuro não nos remete mais ao passado. O tempo linear tomou o lugar do tempo cíclico do eterno retorno. Esta evolução, que culminou no ser humano aponta para um futuro aberto e os graus progressivos de liberdade de ação e poder conquistados colocam em risco a própria existência. "Tão constitutiva para a vida é a possibilidade de não ser que o seu ser é, como tal, essencialmente um estar suspenso sobre o abismo."

Se não há uma ruptura radical entre o inorgânico e o orgânico, como entre a matéria e o 'espírito', se, no plano do orgânico a teleologia é resgatada e incorporada ao acervo de princípios científicos por Hans Jonas, podemos esperar uma reabilitação da virtude da phronesis que se estenderia agora para muito além do mundo do homem (ta andrópina), para o mundo da Physis e faria o contraponto com a 'heurística do medo'.

A Ética aristotélica colocou o homem como responsável por seus atos, tal como o pai em relação a seus filhos. Os novos poderes que a tecnologia colocou em suas mãos estenderam infinitamente suas responsabilidades, não só sobre seus atos como sobre as consequências dos mesmos. Não só para os parceiros e próximos com quem interage no seio de uma comunidade, mas para com as gerações futuras; não só para a Polis, seu habitat mais imediato, mas para o planeta como um todo.

E esta extensão da responsabilidade, para muito além da reciprocidade, amplia o espectro das questões onde a prudência mais do que nunca se faz necessária. Aceitar lidar com o imponderável, conformar-se a uma "lógica da incerteza" exige a revisão permanente de nossas "certezas". Vivemos num mundo pluralista onde a convergência de tradições e valores se perdeu. Donde a necessidade de se lançar mão de outros recursos que não provêm da ciência e da tecnologia, mas da práxis, para tentar fazer com que nos aproximemos não do Summum Bonum, mas do bem ao alcance de nossos atos, iluminados embasados pelo conhecimento teórico, mas balizados pela prudência e a responsabilidade.

\footnotetext{
${ }^{51}$ Jonas, Hans $\mathbf{O}$ princípio Vida, op.cit.
} 


\section{REFERÊNCIAS BIBLIOGRÁFICAS}

ARISTÓTELES, Política Madrid, Instituto de Estudios Políticos, 1951

The Progression of Animals - The Complete Works of Aristotle Ed. Jonathan Barnes, - EUA Princeton University Press, 1985

Ethique a Nicomaque Paris, Vrin,1983

AUBENQUE Pierre: Um modèle aristotélicien pour l'eco-éthique in Problèmes Aristotéliciens, Paris, Vrin,2011

La Prudence chez Aristote, Paris, PUF 1997

Un modèle aristotélicien pour l'eco-éthique in Problèmes

Aristotéliciens, Paris, Vrin,2011

Aristote était-il communautariste? in Problèmes Aristotéliciens -

Philosophie Pratique Paris, Vrin, 2011

La Prudence chez Kant, Revue deMétaphysique et de Morale, $80^{\circ}$. Année, No2,(Avril-Juin 1975) pp.156-182. PUF

BETTTENCOURT DE FARIA, Maria do Carmo Direito e Ética - Aristóteles Hobbes e Kant S.Paulo, Paulus, 2007

Ética do Bem ou Ética da Prudência - Seminário Sênior IFCS/UFRJ, setembro

2013 (inédito)

JONAS, Hans: O Princípio Vida - Fundamentos para uma biologia filosófica, Petrópolis, Vozes, 2004

O Princípio Responsabilidade, Rio, Contraponto-PUCRio, 2006 - Prefácio.

HOBBES, Do Cidadão, S Paulo, Ed. Martins Fontes, 2002- Epístola Dedicatória

Leviatã, S Paulo, Abril Cultural -Col. Os Pensadores, 1974 - cap XI

KANT, I. Crítica da Razão Prática, Rio de Janeiro, Ediouro, s/d.

En torno al tópico: Talvez eso sea correcto en teoria, pero no sirve para la prática in Ensayos sobre la paz, el progreso y el ideal cosmopolita, Madrid, Cátedra, 2005.

KIRK E RAVEN Os Filósofos Pré Socráticos, Lisboa, Fundação Calouste Gulbenkian /1979/ 
LIMA VAZ, Escritos de Filosofia II, S Paulo, Loyola, 1988.

PERELMAN, Chaim e OLBRECHTS-TYTECA, Lucie Nouvelle Rhétorique: Logique et

Rhétorique in LEMPEREUR, Alain, L'Homme et la Rhétorique, Paris, Méridiens Klinksieck, 1990

POPPER, K. O Mundo de Parmênides, S Paulo, UNESP, 2014 


\title{
MORTE CEREBRAL E O ENIGMA DA MORTE
}

Brain death and the enigma of death

\author{
Maria Luiza de Castilho Anciens \\ Graduanda em Filosofia/UFRJ \\ Graduada em Psicologia pela Universidade Gama Filho - Rio de Janeiro/RJ \\ Especialização em Geriatria e Gerontologia pela UFF \\ Capacitação em Cuidados Paliativos pela UERJ \\ Membro da Sociedade Brasileira de Geriatria e Gerontologia \\ Orientadora informal para este trabalho Sarah Moura
}

RESUMO: O temor da morte sempre rodeou a humanidade que procura amenizar esse medo buscando explicações em diferentes correntes culturais, religiosas, sociais. Mas a única certeza da nossa existência é que vamos morrer e não conseguimos até hoje responder o que é a morte. A Filosofia também tenta esclarecê-la através de diferentes correntes de pensamento. Dos présocráticos aos contemporâneos a morte sempre foi uma temática filosófica, talvez mesmo o seu questionamento original. No capítulo 10, "Morte cerebral e banco de órgãos humanos: sobre a redefinição pragmática da morte” do livro “Técnica, Medicina e Ética” de Hans Jonas, ele analisa e discute de maneira profundamente impactante os critérios de morte cerebral e sua utilização para fins de doação de órgãos. A ciência evolui nos critérios da definição fisiológica da morte que era o cessar da respiração e batimentos cardíacos para ausência total das funções celebrais sempre ocasionando grande desconforto para os familiares que precisam autorizar a doação. Ao repensar os critérios de morte cerebral e sua utilização para doação de órgãos, Hans Jonas nos faz rever esse grande enigma da morte questionando até que ponto as novas tecnologias, aparentemente em favor da vida, pode nos levar a questionar os critérios éticos sobre vida, morte e nossa própria existência.

PALAVRAS-CHAVE: Morte; Morte Cerebral; Tecnologia, Hans Jonas.

\section{INTRODUÇÃO}

O temor da morte sempre rodeou a humanidade que procura amenizar esse medo buscando explicações em diferentes correntes culturais, religiosas, sociais. Mas a única certeza da nossa existência é que vamos morrer e não conseguimos até hoje responder o que é a morte. A Filosofia também tenta esclarecê-la através de diferentes correntes de pensamento. Dos présocráticos aos contemporâneos a morte sempre foi uma temática filosófica, talvez mesmo o seu questionamento original. 
Hans Jonas, no capítulo 10 do livro Técnica, Medicina e Ética, intitulado Morte cerebral e banco de órgãos humanos: sobre a redefinição pragmática da morte, analisa e discute de maneira profundamente impactante os critérios de morte cerebral e sua utilização para fins de doação de órgãos. A ciência evoluiu nos critérios da definição fisiológica da morte - que era o cessar da respiração e batimentos cardíacos - para a ausência total das funções cerebrais, sempre ocasionando grande desconforto para os familiares que precisam autorizar a doação. Ao repensar os critérios de morte cerebral e sua utilização para doação de órgãos, Hans Jonas nos faz rever esse grande enigma da morte questionando até que ponto as novas tecnologias, aparentemente em favor da vida, pode nos levar a questionar os critérios éticos sobre a vida, a morte e a nossa própria existência.

Acreditamos que o ato de se dizer doador de órgãos é muito mais emocional que racional. A ciência determinou a constatação da morte pela análise cerebral e a opção de doação de órgãos não passa pelo questionamento do que realmente é a morte cerebral. O celebro é o responsável por todas as nossas funções. Se ele parou é porque não há mais nada que possa ser feito. $\mathrm{O}$ funcionamento por aparelhos é também um avanço científico. Então porque não ser um doador? Será que a morte é realmente cerebral? Será que enquanto nosso organismo ainda funciona por aparelhos estaremos vivos? Esses foram os questionamentos que o texto de Jonas nos faz parar para refletir.

\section{Sobre morte cerebral}

Morte cerebral é o termo comumente usado, mas o correto é dizer morte encefálica. A Associação Brasileira de Transplantes de Órgãos define a morte encefálica como a “ausência total de todas as funções neurológicas em decorrência de severa agressão ou ferimento grave no cérebro e o sangue que vem do corpo e supre o cérebro é bloqueado e o cérebro morre" 1 . Portanto, morte encefálica é o termo empregado pela abrangência anatômica do sistema nervoso central envolvido.

O questionamento de Hans Jonas começou quando a comissão da Harvard Medical School publicou em 5 de agosto de 1968 essa nova definição de morte. Então numa conferência que fez sobre "Aspectos éticos de experimento com seres humanos" ele criticou duramente argumentando:

\footnotetext{
${ }^{1}$ www.abto.org.br/abtov03/dafault.aspz?mn=472\&c=015\&s-0\&friedely=entendendo-a-morte-encefálica
} 
a proposta da comissão de Harvard, ainda que seu objeto não pertencesse propriamente ao tema do experimento com sujeitos humanos: eu via nele, contudo, o perigo do abuso de tais sujeitos (pacientes) para fins médicos não muito diferente do que deveria ser evitado nas situações de experimentação (JONAS, 2013, p 230)

Jonas ainda redigiu o texto Contra a Corrente (Against the Stream) sobre o tema e foi muito contestado pelos médicos, abrindo, assim, a oportunidade de várias discussões sobre esse assunto tão difícil de ser abordado tanto na visão médica como na do senso comum de todos os pacientes e parentes envolvidos. Hans Jonas coloca seus argumentos quanto à definição de Harvard nesses dois principais tópicos:

1) Definia o coma irreversível como "morte cerebral", quando as seguintes características constam no diagnóstico: ausência de toda e qualquer atividade cerebral constatável (eletroencefalograma plano) e de toda atividade física dependente do cérebro, como respiração espontânea e reflexos;

2) Equipara a morte cerebral assim definida com a morte de todo o corpo, portanto do paciente, o que permite, para além da declaração oficial do falecimento, a interrupção de todas as ajudas oficiais de funções por meio do aparelho de respiração e quaisquer outras formas de manutenção - assim como independentemente disso (isto é, com ou sem tal interrupção) a extração de órgãos para finalidades de transplante: a condição de cadáver do corpo que permite isso começa com a determinação da morte cerebral como tal. (JONAS, 2013, p. 230-231)

Quanto ao primeiro argumento, Jonas reconhece que nem haveria necessidade de mudar os critérios de morte porque a própria igreja católica já tinha se pronunciado através da declaração do Papa Pio XII, no ano de 1957: “Quando o estado de inconsciência profunda for dado como permanente, os meios extraordinários para a manutenção da vida não são obrigatórios. Pode-se suspender seu uso e permitir ao paciente morrer" (JONAS, 2013, p 231).

Observamos que aí está o ponto principal do questionamento de Jonas: que a morte seja um processo natural. Que não se utilizem métodos invasivos na prorrogação da vida quando nada mais há a ser feito, nem antecipar a morte para quaisquer fins, mesmo os considerados humanitários. Hans alega que: “Ora, isso, seja para fins de pesquisa ou transplante, me parece ultrapassar o que uma definição (o que é o nosso trabalho) pode justificar" (JONAS, 2013, p 232).

Questionamentos tão abrangentes não podem ficar sob a tutela de uma definição da ciência. Os envolvimentos éticos, religiosos, culturais, sociais envolvidos nessa questão demandam sérias reflexões e não observamos no dia-a-dia a necessária reflexão sobre o assunto. Ninguém tem por hábito falar da própria morte ou pensar como gostaria que ela ocorresse e o que os parentes devem fazer quando esse momento chegar. Ao tentar levantar o tema as pessoas 
são tidas como mórbidas e não se discute quaisquer questões. São muito poucas as pessoas que tem um plano funeral, por exemplo.

Então temos que reconhecer que os questionamentos filosóficos podem abrir um caminho para esclarecer tão difícil questão. O que é o morrer? Até quando devemos prorrogar a vida de um paciente considerado sem condições de sobreviver? Quando devemos manter uma vida para fins de doação de órgãos? Jonas se posiciona dizendo:

Para o primeiro não necessitamos saber onde está a delimitação exata entre vida e morte - nós deixamos a natureza ultrapassá-la, onde quer que ela esteja ou que ela percorra o conjunto de espectro, caso haja mais de uma linha. Nós precisamos saber apenas como fato que o coma é irreversível, para decidir eticamente não opor resistência ao morrer. Para o segundo temos que reconhecer o limite com absoluta certeza e empregar uma definição de morte menos que máxima para cometer, em um estado possivelmente penúltimo, o que apenas o último permitiria, significa arrogar-se um conhecimento que (acredito eu) não podemos ter. Como não conhecemos o limite exato que separa a vida da morte, não nos resta nada menos que a "definição" máxima (ou melhor: determinação característica) da morte - morte cerebral, mais morte cardíaca, mais qualquer outra indicação que possa ser de interesse -;antes de que possa intervir a violência definitiva. (JONAS, 2013, p 233)

Mas, afinal, o que para nós é a morte? Com certeza se fizermos essa pergunta para uma plateia de dez, cem ou mais participantes, ouviríamos respostas diferentes de acordo a cultura, a religião, o modo de ser e pensar. Até mesmo porque essas respostas seriam de leigos e do senso comum. Será que uma definição científica da morte mudaria a opinião dessas pessoas? Observamos no texto de Hans Jonas o que nos parece uma conclusão explicativa do seu questionamento: "é a indeterminação do limite entre vida e morte, não entre sensação e falta de sensação e significa tendermos, em uma zona de incerteza essencial, mais para uma determinação máxima do que mínima da morte" (JONAS, 2013, p 233).

Ao tentar buscar para ciência a definição máxima para morte logo em seguida ele nos apresenta outros argumentos pertinentes ao tema que também deveríamos levar em consideração ao pensarmos na nossa morte e em sermos possíveis doadores. Hans nos faz pensar em questões que infelizmente a maioria da população não tem acesso que é termos um médico assistente, que nos acompanha na saúde e na doença. O direito que temos sobre nossa existência e nosso corpo. Ele diz:

Além disso, é preciso pensar também sobre o seguinte aspecto: o paciente tem que estar incondicionalmente seguro que seu médico não se tornará seu algoz e que nenhuma definição permitirá que ele venha a sê-lo. Seu direito a esta segurança é incondicional e igualmente incondicional é seu direito a seu próprio corpo com todos os seus órgãos. $\mathrm{O}$ respeito incondicional a este direito não viola qualquer outro direito. Ninguém tem, pois, um direito sobre o corpo de outra pessoa. - Para falar ainda em outro espírito, em um espírito religioso: o falecimento de uma pessoa deveria estar rodeado de piedade e protegido da exploração. (JONAS, 2013, p 234) 
O que observamos na nossa rotina com pessoas conhecidas e mesmos nossos parentes? Existe tal respeito pelo corpo humano na maioria dos hospitais que conhecemos? Os direitos dos pacientes são respeitados? Recebemos as reais informações sobre nosso estado de saúde ou de nossos familiares? Temos orientação psicológica e social nesses momentos difíceis em nossos hospitais?

No seu texto Conta a Corrente Jonas não contesta e até aceita que a nova definição quando usada para não prolongar indefinidamente a agonia do paciente e também dos familiares no caso do coma irreversível. Seu questionamento é sobre a liberdade com que a ciência se utiliza dos órgãos. Ao levantar essa discussão, ele foi convidado a passar vários dias como hóspede do Centro Médico da Universidade da Califórnia, assistindo as conferências médicas e até a frequentar as salas de cirurgias para observar a realidade do transplante de doadores e receptores, podendo fazer um trabalho mais apurado ainda sobre suas inquisições anteriores. Apesar de manter sua posição, vários médicos se tornaram seus amigos. Jonas nos diz:

Eu tinha que responder a três objeções com relação à minha primeira polêmica: que meu argumento relacionado aos "cadáveres doadores" impedia os sérios esforços médicos para salvar vidas; que eu fazia frente a fatos científicos precisos com considerações filosóficas vagas; e que desconhecia a diferença entre morte do "organismo como um todo" e a morte de "todo o organismo". (JONAS, 2013, p 237)

Vamos colocar aqui as respostas de Jonas no que se refere a parte filosófica e sintetizar seus argumentos sobre a morte.

No que se refere à acusação de "vagueza", poderia ser que ele mesmo reflita a circunstância de modo vago que meu argumento é - e eu acredito: um argumento preciso - no qual se trata da vagueza, a saber, especificamente da vagueza de um estado. Aristóteles observou certa vez que era sinal de um espírito cultivado não exigir maior exatidão (akribeia) do que o objeto permite, por exemplo, a mesma da política que na matemática. Certas formas do real do qual o espectro vida-morte talvez seja uma - podem ser em si mesmas "imprecisas" ou o saber passível de aquisição sobre as mesmas o seja. Contudo, reconhecer tal estado de coisas faz mais jus a elas do que uma definição precisa, que a elas faz violência. $\mathrm{O}$ que eu ataquei foi justamente a exatidão inadequada de uma definição e sua aplicação prática em um âmbito em si impreciso. (JONAS, 2013, p 238)

Para Hans Jonas só devemos aceitar a "morte do organismo como um todo" porque enquanto se mantém o corpo funcionando com ajuda de aparelhos para que permaneça em bom estado para doação, esse bom estado é estar vivo. Seu questionamento é instigante:

Temos, portanto, um "organismo como um todo" menos o cérebro, que é mantido em um estado parcial de vida, enquanto a máquina de respirar e outros recursos auxiliares estão funcionando. E aqui, no meu modo de entender, a 
pergunta correta não é: o paciente morreu?, mas: o que deve acontecer com ele - ainda sempre um paciente? Essa pergunta não pode, com certeza, ser respondida por meio de uma definição da morte, mas tem que ser respondida com uma "definição" do ser humano e daquilo que é uma vida humana. (JONAS, 2013, p 241)

Contestar essa a nova definição de morte foi um lançar dúvida mais uma vez no grande enigma do que é a morte. Podemos definir cientificamente com base na biologia e fisiologia, mas o enigma continua. O que é o morrer? Da mesma forma que outras perguntas sempre rodearam o ser humano como o por que morremos. A nova definição de morte encefálica produz também estudos atuais bastantes controversos. O jornal Folha de São Paulo publicou na sua edição de 18/7/2016 que no hospital de Anupam, na cidade de Rudrapur, na Índia, o cirurgião ortopédico Himanshu Bansal está conduzindo uma pesquisa com o objetivo de reverter a morte cerebral utilizando-se de células tronco e um coquetel de reprogramação celular com apoio da empresa americana de biotecnologia Bioquark. Num dos argumentos do artigo Contra a Corrente, Hans Jonas lançou uma provável premonição num dos seus argumentos sobre irreversibilidade.

Para ser mais preciso neste ponto: o "irreversível" do cessar pode ter dupla relação: com a função mesma ou apenas com a sua espontaneidade. Um cessar pode ser irreversível na perspectiva da espontaneidade, mas ainda reversível na perspectiva da atividade mesma - em cujo caso um ativador externo deve entrar em atividade no lugar do interno, isto é, no lugar da espontaneidade perdida. Este é o caso nos movimentos respiratórios e contrações cardíacas do paciente em coma (e também, recentemente, do coração artificial!). A distinção não é corriqueira. Pois, se pudéssemos fazer para um cérebro que parou de funcionar - digamos, apenas para o cerebelo - aquilo que agora podemos fazer pelo coração e pulmão, ou seja, fazê-lo trabalhar por meio da ativação externa constante (elétrica, química ou qualquer outra), o faríamos sem dúvida e não discutiríamos que a atividade resultante carece de espontaneidade: o mais importante seria atividade como tal. Esta é uma especulação puramente hipotética e, sem dúvida, irreal para sempre; mas eu duvido que um médico se sentiria legitimado a declarar como morto um paciente por causa da não espontaneidade de sua fonte cerebral, se esta pudesse ser posta em curso através de um auxílio artificial. (JONAS, 2013, p 239/240)

Acontece que essa pesquisa indiana não é aceita pelos neurocirurgiões. Se Jonas estivesse ainda entre nós, com certeza, teríamos textos instigantes sobre essas novas pesquisas. Seu argumento final é realmente para ser pensado e repensado mesmo nos dias atuais.

A linha limítrofe entre vida e morte não é conhecida com segurança e uma definição não pode substituir o saber. A suspeita de que o estado do paciente em coma sustentado artificialmente ainda é um estado residual de vida (como até há pouco também era visto de modo geral em termos médicos) não é sem fundamento. Isso significa que existe razão para a dúvida de que mesmo sem 
função cerebral o paciente que respira esteja completamente morto. Nessa situação de incomensurável não saber e de dúvida razoável, a única máxima correta para o agir consiste em inclinar-se para o lado da presumível vida. (JONAS, 2013, p 244)

Apresentar uma síntese o pensamento de Jonas a respeito da morte encefálica tem como objetivo levantar a dúvida e abrir espaço para outros questionamentos mostrando que a morte continua não só no campo da filosofia, mas no campo das ciências em geral, e até do senso comum, um grande enigma.

\section{REFLEXÕES SOBRE OS CUIDADOS PALIATIVOS}

Consideramos pertinente colocar um tema correlato à dignidade da morte que é a "nova" especialidade médica: cuidados paliativos.

Segundo a Organização Mundial de Saúde (OMS), em conceito definido em 1990 e atualizado em 2002, "cuidados paliativos consistem na assistência promovida por uma equipe multidisciplinar, que objetiva a melhoria da qualidade de vida do paciente e seus familiares, diante de uma doença que ameaça a vida, por meio da prevenção e alívio do sofrimento, da identificação precisa, avaliação impecável e tratamento de dor e demais sintomas físicos, sociais, psicológicos e espirituais (PESSINI \& BERTACHINI, 2004, p 6)

É usual que o senso comum entenda cuidados paliativos com certo preconceito por desconhecer que apalavra paliativo "deriva do latim pallium que significa manto ou cobertor. $\mathrm{Na}$ época das Cruzadas os cavaleiros recebiam esse manto - pallium - para protegê-los das intempéries do caminho na longa jornada" ${ }^{2}$. Quem está doente e sabedor ou não que sua doença não tem mais tratamento e/ou possibilidade de cura o que mais precisa é justamente de proteção, apoio para seguir seu caminho da melhor forma possível, ao lado da família, com o mínimo de sofrimento e dor.

Modernamente, essa especialidade desenvolveu-se através do incansável trabalho de Cicely Saunders (1918-2005), enfermeira inglesa que depois se formou em Assistência Social e Medicina, fundando o St. Christopher's Hospice, pioneiro no atendimento ao paciente que é considerado pelo grau de evolução da sua doença sem possibilidade de cura. Sendo comum ouvir que "não há mais nada a fazer", Cicely Saunders discordava desse prognóstico e insistia que "ainda há muito a fazer".

Esse "muito" é exatamente dar toda dignidade a essa pessoa sofredora, aliviando sua dor e preparando-a para um final de vida com o mínimo sofrimento, e participando das atividades

\footnotetext{
${ }^{2}$ casadocuidar.blogspot.com.br/p/o-que-e-cuidado-paliativo.html
} 
diárias na medida do possível, acompanhado por uma equipe multidisciplinar que o orienta, bem como a sua família.

Infelizmente, no Brasil, ainda são poucos os hospitais que têm equipe multidisciplinar específica para os cuidados paliativos. Porém, em 26 de fevereiro de 2005, foi fundado em São Paulo a Academia Nacional de Cuidados Paliativos que visa difundir e orientar os profissionais de saúde promovendo curso, congressos, debates etc... Sobre esse assunto o escritor Rubens Alves nos fala em seu livro Ostra feliz não faz pérola.

[...] A vida humana só é humana enquanto existe a possibilidade de beleza e riso. Sem beleza e sem risos a vida humana acabou. O que resta é apenas um corpo que deseja morrer. Hoje já se está dando atenção ao que se chama "terapia paliativa". "Paliativo" vem do termo pallium, capa, cobrir, esconder. A terapia paliativa entra em cena quando se sabe que a batalha está perdida. Não há mais sentido para os "recursos heróicos". Quantas quimioterapias sabidamente inúteis deixariam de ser feitas! Quanto sofrimento seria poupado! O objetivo da terapia paliativa é tornar o mais confortável possível a despedida da pessoa que vai morrer. Há de se viver bem. Há de se morrer bem. A ideia de que a medicina é uma luta contra a morte está errada. A medicina é uma luta pela vida boa, da qual a morte faz parte. (ALVES, 2008, p 268)

\section{CONCLUSÃO}

Sabemos o quanto é difícil lidar com a questão da morte e do morrer. Não deveria ser assim. A morte apenas faz parte da existência e o bem viver deve ser o ideal de todo ser para buscar um morrer bem. A decisão de doar órgãos quando declarada a morte encefálica é sempre muito difícil porque geralmente ocorre em pessoas jovens que sofrem acidentes graves. Não é uma morte esperada. Um trauma para qualquer família e como a morte não é assunto a ser debatido fica ainda mais difícil essa tomada de decisão. Conversar sobre esse assunto ajudaria muito se por acaso formos pego de surpresa pela imprevisibilidade. Acompanhar o momento da morte de um ente querido deveria ser rotina familiar, mas geralmente acontece na solidão de um CTI ou de uma enfermaria hospitalar. Elisabeth Hübler-Ross em seu livro Sobre a morte e o morrer nos fornece um refletir primoroso sobre esse momento difícil. Esse texto com certeza complementa o pensamento de Hans Jonas de que o ser humano tem o direito de ter a morte de todo corpo rodeada de ética e dignidade.

Aqueles que tiverem a força e o amor para ficar ao lado de um paciente moribundo, como silêncio que vai além de palavras, saberão que tal momento não é assustador nem doloroso, mas um cessar em paz do funcionamento do corpo. Observar a morte em paz de um ser humano faz-nos lembrar uma estrela cadente. É uma entre milhões de luzes do céu imenso, que cintila ainda por um breve momento para desaparecer para sempre na noite sem fim. Ser terapeuta de um paciente que agoniza é nos conscientizar da singularidade de cada indivíduo neste oceano imenso da humanidade. É uma tomada de consciência de nossa finitude, de nosso limitado período de vida. Poucos dentre nós vivem além dos setenta anos; ainda sim, neste curto espaço de tempo, muitos dentre 
nós criam e vivem uma biografia única, e nós mesmos tecemos a trama da história humana. (HÜBLER-ROSS, 1998, p 28)

Esse texto, com certeza, complementa o pensamento de Hans Jonas de que o ser humano tem o direito de ter a morte de todo o corpo rodeada de ética, dignidade e espiritualidade. 


\section{REFERÊNCIAS}

ALVES, Rubens. Ostra feliz não faz pérola. São Paulo: Ed. Planeta do Brasil, 2008.

JONAS, Hans. Técnica, Medicina e Ética, Capítulo 10:Morte cerebral e banco de órgãos humanos: sobre a redefinição pragmática da morte (pp 229-250). São Paulo: Paulus, 2013.

KÜBER-ROSS, Elisabeth. Sobre a morte e o morrer. São Paulo: Martins Fontes, 1998. Tradução de Paulo Menezes, $8^{a}$ edição.

PESSINE, L \& BERTACHINE, L. (orgs). Humanização e Cuidados Paliativos. São Paulo: Centro Universitário São Camilo\& Edições Loyola, 2004, $2^{a}$ edição.

www.casadocuidar.blogspot.com.br/p/o-que-e-cuidado-paliativo.html

www.abto.org.br $/$ abtov03/dafault.aspz?mn $=472 \& c=015 \& s-0 \&$ friedely $=$ entendendo-a-morteencefálica

www.folha.vol.com.br/ciencia/2016/07/1792720-indianos-tentam-reverter-morte-cerebral.shtml 


\section{O PRINCÍPIO RESPONSABILIDADE E A ENGENHARIA GENÉTICA}

The imperative of responsibility and the genetic engineering

Marijane Lisboa

RESUMO: À época em que Hans Jonas desenvolveu sua reflexão sobre a Ética necessária a uma era tecnológica, as plantas transgênicas ainda não eram uma realidade. Pouco tempo depois da sua morte, no entanto, já se plantavam soja, milho, canola e algodão transgênicos em todos os continentes, alimentos que daí em diante farão parte da dieta global, animal e humana. Embora promovida e defendida pelas grandes corporações internacionais de biotecnologia e pelos países líderes no terreno da inovação tecnológica e patenteamento, cientistas, filósofos e segmentos da sociedade civil em todo o mundo manifestaram fortes restrições à liberação de plantas transgênicas no meio ambiente e na alimentação humana e animal. Além de desnecessária, a engenharia genética é uma tecnologia demasiadamente nova cujos efeitos colaterais são imprevisíveis e caso negativos, irreversíveis, tanto no que se refira à agrobiodiversidade, quanto à saúde humana e animal. Por isso, ainda que Hans Jonas não tenha tido a oportunidade de refletir especificamente sobre essa tecnologia, deveríamos recorrer ao seu Princípio Responsabilidade como fundamento ético do Princípio da Precaução, uma vez que se trata de preservar as condições necessárias à continuidade da espécie no planeta.

PALAVRAS-CHAVE: Princípio Responsabilidade; Engenharia Genética; Princípio da Precaução.

Em primeiro lugar desejo agradecer imensamente aos organizadores do II Seminário Hans Jonas da UFRJ pelo convite para proferir a primeira conferência deste evento, ao mesmo tempo que manifestar mais uma vez o temor de que não esteja à altura de tão honroso convite. Sou socióloga, e não filósofa, e meu vínculo com a filosofia de Hans Jonas estabeleceu-se em uma trajetória absolutamente distinta da maioria dos participantes deste seminário.

Fui durante quase dez anos membro do Greenpeace Brasil onde fui responsável por campanhas contra substâncias químicas e tecnologias perigosas como agrotóxicos, incineradores e fábricas de cloro entre outras. Finalmente, nos dois últimos anos da minha atuação no Greenpeace, me encarregaram da campanha contra transgênicos. Tendo que ao mesmo tempo fazer uma tese de doutorado na PUC-SP onde leciono, escolhi um tema afim com minha 
militância ecológica, ou seja, o comércio mundial de resíduos perigosos ${ }^{1}$. Em toda esse campo técnico que lida com substâncias tóxicas, a grande discussão é sempre se há evidências científicas suficientes de que certas substâncias sejam efetivamente tóxicas ou haveria apenas indícios, que não poderiam ser cientificamente comprovados, nem tampouco descartados. Algumas destas substâncias que no passado se acreditava não tóxicas ou moderadamente tóxicas, contudo, como os inseticidas DDT, se revelaram posteriormente cancerígenas, mutagênicas e perturbadoras do sistema endócrino entre outros efeitos colaterais, gerando em muitos casos danos irreversíveis à saúde humana. Por isso, surgiu na legislação ambiental uma abordagem de precaução, ou de prudência, com se queira chamar. Resumidamente, em dúvida quanto a potenciais danos de certas tecnologias ou produtos, decida-se por uma atitude de proteção à saúde e ao meio ambiente.

Como averiguei em minha tese, o Princípio da Precancão surgiu mais ou menos na mesma época, na legislação ambiental da Suécia e da Alemanha. Ele basicamente estabelece que autoridades não devem alegar ausência de evidências científicas para se furtar a adotar medidas de precaução quando há indícios de que determinadas atividades possam trazer danos sérios aos seres humanos e ao meio ambiente. Atividades que poderiam causar grandes danos, ou que estes eventuais danos pudessem ser irreversíveis ou seus impactos imprevisíveis, deveriam ser evitadas. Inicialmente tornado leis nesses dois países, mais tarde o Princípio da Precaução será um princípio fundamental do direito ambiental, do direito à saúde e também da proteção ao patrimônio histórico entre outros.

Foi assim que cheguei a Jonas. Alguns colegas do Greenpeace da Alemanha, sabendo que eu lia alemão, me presentearam com um exemplar do Das Prinzip Verantwortung, editado pela Suhrkamp². Ao lê-lo, percebi a clara vinculação entre o Princípio Responsabilidade e o Princípio da Precaução, pois o primeiro parecia fornecer a fundamentação filosófica, moral, para o segundo.

O Princípio da Precaução, por outro lado, parecia elucidar as condições e circunstâncias em que o Princípio Responsabilidade de Jonas deveria ser aplicado, condições e circunstâncias essas que o filósofo apenas delineia ao tratar de algumas daquelas limitações em pesquisa científica e desenvolvimento científico cujos "objetivos e meios seriam eticamente recusáveis". Escrevi então um artigo sobre a relação entre os dois princípios que saiu na revista Margem, da Faculdade de Ciências Sociais, há algum tempo atrás ${ }^{3}$.

\footnotetext{
Minha tese será mais tarde publicada pela Civilização Brasileira: Ética e Cidadania Planetárias na Era Tecnológica: o caso da Proibição da Basileia. Civilização Brasileira, RJ, 2009.

2 Hans Jonas, Das Prinæip Verantwortung: Versuch einer Ethik für die technologische Zivilisation, Suhrkamp taschenbuch, Frankfurt am Main, 1993.

3 Lisboa, M. O fundamento ético do Princípio da Precaução, Margem, São Paulo, nº21, pags.77a 91, Junho de 2005.
} 
Alguns anos depois, a Editora Contraponto, para quem eventualmente traduzo do alemão, me pediu para fazer a revisão da tradução do Princípio Responsabilidade de Hans Jonas, e logo em seguida para que eu continuasse a tradução da obra, já que o primeiro tradutor havia desistido de continuá-la. Finalmente, há quase dois anos atrás, ao ser convidada para a banca de uma tese no Programa de Filosofia da PUC-SP, tive oportunidade de conhecer os professores Jelson Roberto de Oliveira e Helder de Carvalho, que em seguida me convidaram para ingressar no grupo de trabalho Hans Jonas da ANPOF e também para participar do Colóquio Hans Jonas em Teresina, entre 18 e 20 de novembro do ano passado.

Quando escolhi o tema da minha palestra naquele Colóquio, pensei que o melhor que poderia fazer como socióloga em um evento de filósofos seria mostrar como a filosofia de Hans Jonas pode ser útil aos filósofos e também aos não filósofos para orientar-se em meio a questões atuais da política ambiental, ajudando-nos a pensar os desafios éticos dessa política. Assim, peço que me perdoem aqueles colegas que assistiram à minha palestra em Teresina, porque vou repetila em grande parte.

\section{Por que Engenharia Genética?}

Esse é um dos temas com os quais tenho lidado há mais de 10 anos de modo sistemático, desde o período em que atuei no Greenpeace até os dias de hoje. Mesmo depois que saí dessa organização, o tema dos transgênicos não me abandonou e acredito que ao expô-lo também vou conquistar alguns corações e mentes para ele entre vocês. Passei quatro anos representando os consumidores em uma comissão, a Comissão Técnica Nacional de Biossegurança - CTNBio, que é encarregada no Brasil da política referente à engenharia genética. Concluí no começo desse ano o segundo mandato de dois anos e ainda que tenha sido uma experiência muito frustrante por razões que exporei mais adiante, foi uma campo fertilíssimo para mostrar como é possível que cientistas e autoridades públicas ignorem esses dois princípios que estão tão integralmente relacionados: o Princípio Responsabilidade e o Princípio da Precaução.

Curiosamente, a questão da aplicação de tecnologias modernas às plantas é uma das questões para as quais Jonas acredita que se possa arcar com riscos do desenvolvimento tecnológico. Assim, na longa entrevista ou debate transcrita ao fim do livro Técnica, Medicina e Ética, editada pela Paulus e traduzida pelo Grupo de Trabalho Hans Jonas da ANPOF ${ }^{4}$, Jonas, na página 318, afirma que embora se conheçam os inconvenientes perigosos do emprego de aditivos químicos para aumentar o rendimento das plantas, estes deveriam ser permitidos até que

4 Hans Jonas, Técnica, Medicina e Ética: sobre a prática do princípio da responsabilidade, Paulus, SP, 2013. 
se encontrasse soluções mais adequadas e que se eliminasse a necessidade de aumentar o rendimento das plantas, ou seja, até que se eliminasse a fome sobre a Terra e a produção deficiente em certas regiões, como é o caso do Terceiro Mundo.

Então, nessa minha conferência, irei discordar de Jonas - espero que me perdoem - mas mostrarei que embora ele se equivoque na questão empírica, o que é natural tratando-se de um filósofo - seu Princípio Responsabilidade continua sendo o princípio mais adequado também para lidar com os experimentos e com os novos "objetos" criados pela engenharia genética. Ou seja, que malgré lui, ele está certo, ou apesar de ter se equivocado, continua certo.

Comecemos, portanto, pelo que sejam transgênicos. Podem sem animais, mas nos dias de hoje são sobretudo plantas nas quais se inseriram genes de outras plantas, insetos, vírus ou bactérias de modo que elas apresentem propriedades que elas não tinham anteriormente. Dado que seres vivos, e animais e plantas em particular só transferem material genético verticalmente, ou seja de uma geração para outra, a engenharia genética faz algo que até então era desconhecido na Natureza, ou seja, a troca de material genético horizontalmente.

A soja transgênica Roundup Ready ${ }^{5}$, por exemplo, tem um gene de uma planta que é tolerante a um determinado agrotóxico. Outros genes também são enxertados em seu DNA para que aquele gene desejado penetre efetivamente nesse DNA e permaneça ativo nas gerações seguintes. Também se produziu um milho transgênico no qual se inseriu o gene de uma bactéria muito comum no solo, que secreta uma toxina que mata certos insetos que atacam o milho ${ }^{6}$. Em nenhum desses casos, portanto, como Jonas julgou erroneamente, assistimos a um aumento do rendimento ou da produtividade agrícola. Temos apenas plantas sobre as quais pode-se jogar grande quantidade de agrotóxicos sem que morram, ou outras que contêm elas mesmas, em seus grãos e folhagem, agrotóxicos que matam as pragas que as atacam.

Mas a que se referia Jonas ao falar de tecnologias que aumentam a produtividade apesar de seus inconvenientes? Certamente não a transgênicos, que àquela época, 1984, ainda não existiam em escala comercial. Ao se referir a "aditivos químicos", provavelmente estaria considerando o emprego intensivo de em fertilizantes e agrotóxicos, além da técnica de irrigação consumidora de energia, que ele menciona explicitamente nessa passagem.

Ora, esse pacote tecnológico composto de irrigação, uso de fertilizantes e agrotóxicos, seleção de sementes e mecanização da agricultura acabou por receber o nome bastante impróprio de Revolução Verde. Aplicado no mundo todo a partir dos anos 40, ele revolucionou a agricultura,

5 A Soja RR foi a primeira planta transgênica introduzida comercialmente no mundo, produzida pela transnacional estadunidense Monsanto.

6 O Bacilus Turingensis, conhecido dos agricultores orgânicos e utilizado nos casos bastante raros de infestação de pragas, por meio de uma calda. 
transformando-a num grande negócio de dimensões nacionais e internacionais. A produção de grãos aumentou exponencialmente e o seu preço caiu, embora não se possa dizer o mesmo da produtividade. Por hectare, por uso de recursos naturais como terra, água, conservação de diversidade agrícola e ecológica, o agronegócio nunca foi nem é mais produtivo que o seu modesto antepassado, a agricultura camponesa ${ }^{7}$.

Praticada em pequena escala, a agricultura camponesa em qualquer de suas muitas tradições culturais - europeias, de povos indígenas americanos, africanas, chinesas, indianas e japonesa - sempre foi mais produtiva, pois soube aproveitar melhor os recursos naturais - terra, água, biodiversidade e força de trabalho - sem degradá-los por meio do uso intensivo de fertilizantes, agrotóxicos, irrigação, compactação do solo por mecanização, gasto com combustíveis fósseis e emissão de gases de efeito estufa, entre outros aspectos. Simplesmente não se pode ganhar muito dinheiro com ela. De modo a não se expor o solo às intempéries, ocasião em que se perde seu material nutritivo, não se pode cultivar grandes extensões da mesma planta, proceder à colheita em um só momento e se deixar o solo nu, exposto ao sol e a chuvas. A irrigação constante pode trazer salinização e apodrecimento das raízes e associada aos agrotóxicos, contaminar o solo, matar a microfauna, os insetos benéficos à agricultura, contaminar o lençol freático, intoxicar animais e seres humanos que bebem essa água. Não preciso certamente mencionar os danos para a nossa saúde que advêm do consumo de plantas sobre as quais se jogou grande quantidade de agrotóxicos.

A lógica comercial do agronegócio leva também a abandonar variedades de plantas que são mais difíceis de transportar, conservar ou menos requeridas pelos mercados, fazendo com que hoje em dia tenhamos perdido grande parte das variedades de arroz, trigo, milho e feijão que eram cultivadas até o começo do século passado.

Finalmente não devemos nos esquecer que o agronegócio requer grandes extensões de terras e dado o fato de que ele degrada o solo e exaure os recursos hídricos, tende a avançar e devorar novas terras ainda não cultivadas que encontre à sua frente, sendo esta a causa do interminável desmatamento do Cerrado brasileiro, da Floresta Amazônica e do que resta da Mata Atlântica.

Assim, a razão da Revolução Verde não foi o generoso objetivo de alimentar os famintos da Terra, mas o de tornar o alimento uma commodity, produzida em massa, vendida em massa, consumida em massa pelo mercado mundial de alimentos. E enganou-se Jonas, também, ao crer que o Terceiro Mundo passasse fome porque sua produção agrícola fosse deficiente ou

7 A respeito da agricultura camponesa: Alier, Joán Martinez, Da Economia Ecológica ao Ecologismo Popular, Editora da FURB, Blumenau, 1998;Carvalho, Horácio Martins de, O Campesinato no Século XXI, Editora Vozes, Petrópolis, 2005; Petersen, Paulo (org.) A Agricultura Familiar Camponesa na Construção do Futuro, AS-PTA< RJ, 2009; Shiva, Vandana, Monoculturas da Mente:perspectivas da biodiversidade da biotecnologia, Editora Gaia, SP, 2003. 
demasiado cara. Passa-se fome porque roubou-se as terras de boa parte da nossa população indígena que conseguiu sobreviver ao extermínio dos primeiros tempos; porque libertou-se os escravos, mas não se lhes deu terras e porque, continuamente, rouba-se as terras dos camponeses brasileiros, que quando as tem, tem pouca, minifúndios, e frequentemente as mais áridas. $\mathrm{O}$ campesinato familiar tampouco tem crédito rural fácil, isenções de impostos e financiamento de equipamentos, tudo o que sobra para o agronegócio brasileiro, por exemplo. Mas, mesmo assim, o campesinato familiar faz milagres, pois é responsável por boa parte dos alimentos que consumimos.

Fosse a agricultura indígena do Terceiro Mundo pouco produtiva, e os europeus não teriam encontrado nas Américas uma população superior a 50 milhões de pessoas segundo estimativas dos especialistas, bem nutridas e com aparência invejável se comparada a eles. Mas, entre pestes, trabalho escravo nas minas e roubo de suas terras, hoje sobrevive apenas uma parte mínima desses indígenas ${ }^{8}$. O mesmo podemos dizer das enormes populações agrárias da Ásia e África, que desconheceram a fome até a chegada dos europeus. Expulsos de suas terras pelo imperialismo europeu, uma enorme massa despossuída se concentrou em suas cidades e à essa massa é que falta trabalho e dinheiro para comprar comida. As estatísticas internacionais mostram que o planeta hoje produz mais alimentos do que o suficiente para alimentar decentemente sua população. O problema da fome não é um problema de volume de produção, mas de distribuição desigual de recursos para ter acesso aos alimentos: terra e renda. Enfim, um problema social.

Dito isso em discordância com Jonas, ainda tenho bastante a dizer sobre essa neta da Revolução Verde que é a Engenharia Genética. Como já disse antes, a grande maioria dos transgênicos até hoje "inventados", tem como objetivo permitir que o agronegócio use maior quantidade de agrotóxicos em plantas a eles tolerantes, matando as chamadas ervas invasoras, ou eliminar a necessidade de aplicação de agrotóxicos, ao transformar as próprias plantas em agrotóxicos. A economia de recursos na aplicação de agrotóxicos redunda, portanto, em maior consumo de agrotóxicos de nossa parte. Não foi à toa que depois da adoção da soja e milho transgênicos no Brasil nos tornamos seus maiores consumidores, ultrapassando os EUA nesse aspecto. Agricultores interessados em vender seus alimentos independentemente de sua qualidade, vem nisso um bom negócio, pois com poucas fumigações de um mesmo agrotóxico, economizam em aplicações sucessivas e mão de obra. Empresas de biotecnologia, a maioria transnacionais - Monsanto, Singenta, Bayer, Basf e Du Pont entre as maiores - são na verdade as

8 Sobre a catástrofe demográfica que aniquilou grande parte da população pré-colombiana ver: Crosby, A., Imperialismo Ecológico, Companhia das Letras, SP, 1993; Diamond, J., Armas, Germes e Aço:os destinos das sociedades bumanas, Record, RJ, 2001; Rouland, N., Direito das minorias e dos povos autóctones, Editora UNB, Brasília, 2004. 
que mais ganham com a venda de sementes transgênicas e os agrotóxicos a elas associados. Patenteando suas plantas transgênicas, fidelizam à força os produtores rurais, que passam a ter que comprar suas sementes todas as vezes que plantam, pois o retorno à agricultura convencional é difícil, senão impossível, dada a contaminação das variedades convencionais pelas transgênicas. As indústrias químicas também ganham, portanto, bem como as indústrias de máquinas. A Revolução Verde é assim um excelente negócio, menos para a humanidade e para o meio ambiente.

Uma pequena lista dos danos irreversíveis que a transgenia pode causar?

As plantas "engenheiradas" podem trocar material genético com suas parentas, chamadas convencionais e na seleção natural podem se sair melhor e eliminar a existência dessas últimas. Não é possível saber o que acontecerá em cada caso e em cada ecossistema. O experimento está sendo feito em tempo real e em escala sem procedentes. Se isso acontecer, perderemos variedades de plantas que nossos camponeses e populações indígenas levaram milênios para domesticar e adequar à alimentação humana e animal. E, como sabemos, somos capazes de destruir a Natureza, mas não de criá-la.

As plantas transgênicas ou os agrotóxicos a elas associados podem matar abelhas, pássaros, mariposas, borboletas e causar grandes danos aos ecossistemas nos quais esses insetos e animais cumprem um papel fundamental. Sem tais insetos, é possível que tenhamos quebras de safra monstruosas e grandes fomes. Boa parte das plantas com as quais nos alimentamos são fertilizadas por esses insetos e animais.

A inserção genética em organismos estranhos a eles pode produzir proteínas desconhecidas que podem gerar enfermidades também desconhecidas em nós e nos animais ou intensificar aquelas enfermidades que já conhecemos como alergias, mutações genéticas, cânceres. É possível que levemos décadas para descobri-lo e talvez mais ainda outras décadas, para combatê-las.

Finalmente, plantas são serem vivos, se reproduzem naturalmente. Uma vez liberadas no meio ambiente, plantas transgênicas não são passíveis de recall. Por isso, dizemos que plantas transgênicas oferecem riscos imprevisíveis e em grande parte irreversíveis, além de serem desnecessárias. Os sistemas agroecológicos, que são a combinação dos conhecimentos milenares de nossos agricultores com a moderna ciência agroecológica, são perfeitamente capazes de alimentar o mundo, caso recebam os mesmos estímulos e recursos destinados ao agronegócio. Diz-se comumente que a agricultura orgânica seria incapaz de alimentar o mundo, o que não é

9 Sobre a discussão a respeito de benefícios e riscos de transgênicos: Andrioli, A.I. e Fuchs R., (Orgs.) Transgênicos: As Sementes do Mal: a silenciosa contaminação de solos e alimentos, Expressão Popular, SP, 2008; Lacey, Hugh, $A$ Controvérsia sobre os Transgênicos, Ideias e Letras, Aparecida, 2006; Zanoni, M., e Ferment, G., Transgênicos para quem? Agricultura Ciência e Sociedade, MDA, Brasília, 2011. 
verdade. O agronegócio que recorre a alta tecnologia só produz mais, porque é ajudado a produzir. Olhemos para nós, no Brasil. Grandes produtores de soja, milho, cana-de-açúcar e de carne de vaca, aves e porcos, que exportamos - consumimos o arroz, feijão, milho, mandioca, verduras e frutas - produzidos fundamentalmente pela agricultura familiar, que enfrenta enormes dificuldades por não encontrar crédito público suficiente e não ter as suas dívidas periodicamente perdoadas, como acontece com os seus grandes concorrentes.

Bem, retornando a Jonas: se as tecnologias da Revolução Verde não são a solução para a fome, e se ao contrário, ela e a Engenharia Genética são elas mesmas grandes ameaça à segurança alimentar da humanidade devido à degradação do solo, contaminação das águas, perda de biodiversidade agrícola e desperdício de energia fóssil que requerem - e se somamos a isso as mudanças climáticas que aí estão e que certamente aumentarão as regiões sujeitas a um crescente estresse hídrico - então, seguindo o raciocínio de Jonas, também a Engenharia Genética e o pacote tecnológico da Revolução Verde não deveriam ser estimuladas, nem permitidas.

E aqui não se trata apenas de pesquisa e experimento científico que siga caprichos e não necessidades humanas que podem ser consideradas como éticas, casos em que Jonas considera que não se deva permitir experimentos com seres vivos. $O$ objetivo da transgenia agrícola é meramente o lucro, cabendo seus benefícios a apenas um punhado de empresas, grandes agricultores e beneficiadores de alimentos, enquanto seus danos recaem sobre a humanidade e o meio ambiente nessa e em futuras gerações.

E aí encontramos Jonas novamente. Que direito temos de ameaçar a saúde diretamente e indiretamente a sobrevivência da humanidade, comprometendo um patrimônio da biodiversidade agrícola que todos os povos que vieram antes de nós, desde que se tornaram sociedades agrícolas, desenvolveram e preservaram para nós? Foram eles os verdadeiros cientistas, os que selecionaram plantas individuais mais suculentas, mais nutritivas, mais doces e por meio de cruzamentos durante milênios as legaram a nós. Se a bumanidade deverá existir - e creio que esse é um mandamento que a Ética nos impõe - deverá ela sucumbir lentamente por fome e desnutrição em meio a guerras civis e guerras entre países pelas poucas terras férteis que restarão? Ou, na melhor das distopias cientificas, sobreviver comendo pílulas de concentrados químicos, distribuídas por sabemos lá que tecnocracia governante, sem o direito de comer como nós, alimentos saudáveis, variados, gostosos e nutritivos?

Se respondemos positivamente a essa pergunta, a la Jonas, então não podemos chamar o que ocorre nos nossos órgãos registradores de transgênicos no Brasil, como a Comissão Técnica Nacional de Biossegurança-CTNBio ${ }^{10}$, mas também em outros de muitos países, como os da

10 Glass, V., A Ciência Segundo a CTNBio, Revista Sem Terra, ed.54, nov/dez. 2009; Marinho, C.L,C e Minayo- 
União Europeia, da Argentina ou dos EUA, de uma conduta ética.

De fato, embora o Princípio da Precaução conste do Protocolo de Cartagena, o princípio que advoga justamente uma atitude de prudência frente às novas tecnologias, e que o Protocolo que pertence à Convenção sobre Diversidade Biológica tenha sido assinado por uma grande parte dos países membros do sistema ONU como princípio norteador das suas decisões, todas as autorizações para o plantio comercial e o consumo humano e animal de plantas transgênicas dadas em países como os EUA, Argentina, Canadá, Espanha e vários outros, não o respeitam.

Além disso, embora haja razoáveis diferenças nas legislações dos diversos países quanto aos trâmites legais a que são submetidos os pedidos de liberação de transgênicos no meio ambiente e para a alimentação humana e animal, esses trâmites exigem muito pouco no que concerne à pesquisa sobre possíveis efeitos colaterais. O ponto de partida desses processos não é o resultado de pesquisas independentes que trazem melhorias para os eventuais problemas da produção agrícola atual, mas a solicitação de liberação dos seus "produtos" desenvolvidos nos seus departamentos de pesquisa por parte transnacionais da biotecnologia aos órgãos responsáveis, em geral, primeiramente nos EUA, depois na Argentina e em seguida no Brasil, aí então arriscando-se uma autorização na União Europeia.

As análises de risco são feitas, portanto, pelas próprias empresas e os órgãos fiscalizadores apenas conferem se tais estudos seguem os protocolos estabelecidos e se chegam à conclusão sobre a inocuidade dos seus "produtos". Tais protocolos, por sua vez, resumem-se a alguns poucos estudos, bastante básicos, estudando-se a toxicidade aguda para ratos durante um curto período e comparando-se as novas toxinas produzidas com as existentes e já conhecidas.

É preciso dizer que nenhum transgênico até hoje foi rejeitado por um desses órgãos e por isso, até hoje, todos os transgênicos desenvolvidos, foram em seguida liberados para uso comercial e consumo humano e animal. Por isso, temos várias sojas e muitos milhos transgênicos que fazem hoje parte da nossa alimentação diária, bem como da ração dos animais. Não se pesquisa, nem se exige que se pesquise a toxicidade crônica; não se examinam efeitos adversos em animais prenhes e não se testam os alimentos transgênicos em pelo menos dois mamíferos, como já hoje se faz em relação a remédios. Pior que isso, move-se uma campanha publicitária de difamação contra aqueles poucos cientistas independentes que ousaram pesquisar transgênicos e encontraram indícios de efeitos preocupantes na saúde animal, como cânceres.

Os muitos impactos de longo prazo ao meio ambiente são igualmente minimizados, conformando-se os cientistas em exigir que os plantios respeitem distâncias bastante exíguas. A

Gomes, C, Decisões Conflitivas na Liberação dos Transgênicos no Brasil, São Paulo Perspectiva, nr.18, SP, 2004; Santos, L.G.dos, Os Biotecnólogos Brasileiros em Face da Sócio e da Biodiversidade, in Novos Estudos Cebrap, nr.78, SP, julho 2007. 
relação entre o plantio de transgênicos e o aumento do uso de agrotóxicos a eles associados também é considerada como assunto que está fora de sua responsabilidade, cabendo não a eles, dizem nossos cientistas responsáveis pela biossegurança, mas a outros órgãos, os encarregados do controle do emprego de agrotóxicos, examinar o assunto. Fatia-se assim, em uma análise cartesiana, o conjunto dos elementos que funcionam entrosadamente na natureza: genes, organismos e ecossistemas. Conclui-se a partir do laboratório, o que ocorrerá no planeta: a partir de meses, o que deverá ocorrer em décadas ou séculos. Enfim, a pesquisa científica requerida é desenhada para que não se encontre nada. E caso se encontre, que este resultado seja considerado como "não significativo".

Não é de estranhar, portanto, que após mais de 20 anos da disseminação massiva do agrotóxico Glifosato, o princípio ativo do herbicida mais usado no planeta em associação com a soja e o milho transgênico da Monsanto, alarmes finalmente soem aqui e ali. O International Agency for Research on Cancer - IARC, anunciou recentemente que o glifosato é cancerígeno para animais e provavelmente para seres humanos ${ }^{11}$. O Instituto Nacional do Câncer - INCA, considerou que o aumento exponencial de cânceres no Brasil estaria relacionado ao aumento do consumo de agrotóxicos, e em especial ao Glifosato, associado a plantas transgênicas ${ }^{12}$. Correm os lobistas das transnacionais de biotecnologia para extrair desmentidos ou encomendar pesquisas desenhadas para não encontrar nada junto a instituições que costumam receber financiamentos dessas empresas ou que são mais flexíveis a pressões políticas, como a recente declaração da FAO/OMS, argumentando que o glifosato não poderia ser cancerígeno para humanos, "devido ao modo como ele é empregado".

Tampouco do ponto de vista ambiental são exigidas as pesquisas necessárias, bem como são ignorados os sinais enviados pela natureza. No México, país de origem da domesticação do milho, encontrou-se milho transgênico no planalto central, embora até hoje o México não tenha autorizado o seu plantio. Acontece que a importação de milho transgênico dos EUA para ração animal não é capaz de impedir que grãos caídos na terra germinem e mais tarde troquem material genético com outros ${ }^{13}$. A Sindrome do colapso das colmeias, que tem levado ao desaparecimento súbito de abelhas é atribuída à intoxicação com agrotóxicos e não se deve excluir que alguns deles estejam associados aos cultivos transgênicos. A alta mortalidade das borboletas monarcas

11 International Agency for Research on Cancer, WHO, LARC Monographs Volume 12: evaluation of five organophosphate insecticides and herbicides, 20 March, 2015.

12 INCA, Ministério da Saúde: Posicionamento do INCA - José Alencar Gomes da Silva - acerca dos agrotóxicos, nr. 010.

13 Price and Cotter, The GM Contamination Register: a review of record contamination incidents associated with genetically modified organisms (GMOs) 1997-2013. International Journal of Food Contamination, 2014, 1.5. 
também pode ser decorrente de agrotóxicos associados aos transgênicos ${ }^{14}$ e assim é possível que estejamos solapando o patrimônio agrobiodiverso que os povos que consideramos "primitivos" nos deixaram e estejamos semeando um mundo estéril e monótono, onde apenas crescem e vicejam as ervas invasoras e as pragas que nele conseguirão sobreviver.

Quando, contudo, se exige a aplicação do Princípio da Precaução, empresas, cientistas e governos argumentam à boca pequena que ele impede o progresso da ciência e que essa, além disso, é neutra e busca apenas a verdade. Tudo, portanto, que Jonas com tanta propriedade criticou no discurso científico que crê em uma ciência sem interesses e livre de problemas éticos, está presente no debate sobre os transgênicos e é preciso dizer, de forma bem mais concreta $e$ generalizada, do que os seus temores em relação às manipulações com o corpo e a mente da nossa espécie.

Pois enquanto ainda discutimos e enfrentamos muita resistência das sociedades em relação a um cartão verde para a clonagem humana ou para a reprodução assistida por meio da manipulação dos genomas, no caso dos transgênicos eles já estão no nosso prato de comida, nos nossos campos e florestas, progredindo insidiosamente à sombra de autoridades, cientistas e empresas em uma associação altamente perversa.

Em suma, é preciso convocar o Princípio Responsabilidade com urgência, nos órgãos públicos que decidem sobre nossa biossegurança como a CTNBio e nos demais órgãos semelhantes de outros países, pois eles já estão decidindo o destino da humanidade, sem consultá-lo. Precisamos de Hans Jonas urgentemente na Biossegurança.

14___ Transgênicos podem afetar borboleta monarca - Ambientebrasil

noticias.ambientebrasil.com.br/.../72873-transgenicos-podem-afetar-borboleta-monar... 


\section{SOBRE A NECESSIDADE DE UMA NOVA FILOSOFIA DA NATUREZA: APROXIMAÇÕES ENTRE FRANCK TINLAND E HANS JONAS \\ On the necessity of a new philosophy of nature: approximations between Franck. Tinland and Hans Jonas}

Sarah Moura

Doutoranda em Filosofia - UFRJ

Orientador Ricardo Jardim

Coorientador Olinto Pegoraro (PPGBios/UERJ)

Mestra em Filosofia pela UFRJ

Graduada em Medicina e Filosofia pela UFRJ

RESUMO: Hans Jonas (Alemanha, 1903 - EUA, 1993) considera a compreensão moderna da Natureza como objeto da ciência um grande equívoco que repercutiu profundamente na humanidade e na biosfera. A hegemonia tecnocientífica da sociedade de consumo de nosso tempo pode ser entendida como uma realização do projeto moderno, cujo êxito se mostra, já há várias décadas, como uma verdadeira ameaça para a vida humana e não-humana de todo o globo terrestre. No Princípio Vida, Jonas refuta o dualismo cartesiano e sustenta uma visão do homem integrado à natureza, e que seres humanos e natureza integram um mesmo sistema, no qual a nossa espécie, como todas as outras, irrompeu da natureza e dela depende para existir. Franck Tinland, Professor Emérito de Montpelier III, nascido na França em 1932, corrobora e enriquece as sustentações jonasianas, asseverando a exigência de uma nova Filosofia da Natureza. Esta comunicação evidencia as convergências entre Jonas e Tinland, que se preocupam em fundar, a partir de uma Filosofia da Vida ou de uma Filosofia da Natureza, uma nova ética que visa a preservação da vida futura, que reflita sobre o agir humano dominado pela tecnociência e pelo consumismo, que analise as ameaças decorrentes desse comportamento predador, ou seja, uma ética da responsabilidade pela vida.

PALAVRAS-CHAVE: Hans Jonas; Franck Tinland; Filosofia da Natureza. 


\section{INTRODUÇÃO}

Professor Franck Tinland sustenta a irredutibilidade da vida ao jogo de forças que operam os sistemas biológicos, que a ciência moderna cada vez desvenda mais. O conhecimento que a humanidade acumulou sobre a natureza desenvolveu-se extraordinariamente desde o século XVII, com a edificação da ciência moderna. Entretanto, Professor Tinland afirma ter ocorrido uma espécie de monopolização das representações do mundo com base na ciência (Cf. HOTTOIS, 1993, p 54).

Esta concepção mecânica do mundo, consequência da ruptura cartesiana das duas substâncias, reflete a oposição entre a res cogitans e a res extensa, que concretiza uma diferença radical entre o pensamento e o mundo, e no próprio homem, a reparação entre o pensamento e o corpo. Muitos autores já mostraram o equívoco de Descartes, como Hans Jonas e Franck Tinland, que afirmam que as paixões da alma e os movimentos voluntários desmontam o esquema cartesiano.

Segundo Tinland, desde Descartes a filosofia se fundo no sujeito e as ciências buscam conhecer as leis naturais para elaborar um uso calculado da natureza (Cf. HOTTOIS, 1993, p 54). Tinland exorta a filosofia a mais uma vez observar os limites do conhecimento que se obtém por meio de procedimentos ativos, controlados, científicos. Ora, a filosofia se interessa pela ciência pelo viés epistemológico, com aquilo que importa ao interesse humano.

A natureza separada da experiência do sujeito é um mecanismo que não possui finalidade interna e que a engenharia, por meio de seus cálculos, destina aos agentes que transformam as matérias primas da natureza em produtos para o mercado. Com isso, multiplicam-se as formas e os meios de trabalho, os corpos e os desejos dos consumidores são alimentados. Esse processo se dá por meio da apropriação do mundo graças à mediação de técnicas e a assimilação da realidade física do mundo pelos homens, e nutre a esperança de um existir melhor. O desejo que movia Descartes era de que seus descendentes pudessem colher os frutos da "árvore do conhecimento" da mecânica, da medicina e da moral (Cf. HOTTOIS, 1993, p 54s).

A novidade da ideia de progresso se impôs em menos de um século. Se na Antiguidade o mundo era considerado perfeito e pleno, na Modernidade surge a ideia de progresso, de que o mundo poderia ser melhor em relação à vida humana.

As crises nos revelam as contradições do momento em que vivemos, onde há propostas antagônicas para solucionar os problemas, mas todas concordam sobre o fato de que o amanhã será melhor do que hoje. Entretanto, a crise se tornou um estado multidimensional que exige uma reflexão sobre a necessidade do progresso. Tinland ilustra esta situação com uma fala do 
presidente norte-americano Jimmy Carter no Discurso sobre o estado da União, em 1979: "Nós sempre cremos que nossas crianças viveriam melhor do que nós. É chegada a hora de pensarmos que isso não é mais verdadeiro”.(Cf. HOT'TOIS, 1993, p 56, nota 1)

Por certo mudamos o mundo, e, segundo Tinland, agora somos confrontados a uma reavaliação da mesma grandeza que aquela vivida no início dos tempos modernos por Bacon, Galileu e Descartes, dentre outros. Esta reflexão crítica sobre nossa crença no progresso torna a compreensão do sentido de natureza um problema a ser enfrentado.

O poder de nossas ações cresceu demasiadamente e se afirmou como domínio sobre a natureza. Nossas "conquistas" vieram a condicionar nosso modo de ser e de agir no mundo. A existência humana, a vida, enfim, tudo que nos é dado pela natureza, se encontra sob a ameaça vinda do agir humano.

Assim, pode-se dizer com Jonas e Tinland que a natureza assumiu grande risco ao deixar nascer o homem. A vulnerabilidade crítica da natureza pela ação técnica do homem é algo que só foi percebido quando os estragos foram detectados.

Nosso poder tecnocientífico se estende a toda a biosfera, e nossa ação técnica desmedida revela a vulnerabilidade crítica da natureza diante desse modo de ser e de agir que a humanidade manifestou. Passamos a ser responsáveis pela natureza justamente porque adquirimos imenso poder sobre ela.

Nós nos sabemos responsáveis por nossas crianças, por nossos concidadãos, por nossos semelhantes no limite extremo. Mas onde cessaria nosso poder passaria também o limite entre a preocupação ética e o direito de usar, até mesmo abusar, dos meios os quais nós tiramos nossa capacidade de agir, nosso poder. (HOTTOIS, 1993, p57)

Diante da circunstância em que nos encontramos, o temor, afirma Jonas, é salutar, especialmente quando o perigo extremo se disfarça atrás de utopias que alimentam esperança de uma reconstrução da natureza e do homem.

A própria ciência já nos alerta para o perigo da ação técnica da humanidade. A natureza para a qual devemos adaptar o conceito para a nova medida de nosso fazer é aquela que aparece de nossos saberes, os quais permitem, mas não legitimam a dominação da natureza para exploração predatória de seus recursos. "É, assim, do interior mesmo da racionalidade científica e de seus resultados que provém a revelação dos limites que se opõem à expansão indefinida do domínio técnico". (HOTTOIS, 1993, p 59).

Não podemos nos permitir a crença em uma regulação última, providencial, por meio da qual a natureza poderia se preservar, ela mesma, e, assim também nós seríamos preservados. Pois os excessos cometidos nos últimos duzentos anos, e acentuadamente a partir da segunda metade 
do século XX, ultrapassaram os limites de segurança de modo arriscado em relação ao futuro da humanidade. A natureza pode ser o lugar de processos apocalípticos do ponto de vista dos fins humanos (Cf. HOTTOIS, 1993, p 59), pois as alterações ambientais podem por em perigo a manutenção das condições da vida humana autêntica e digna.

Tinland e Jonas não negam a legitimidade da ação humana sobre a natureza, mas é preciso ler na própria ordem natural os limites de nosso direito de agir sobre ela. Para Tinland, "a natureza de Hans Jonas é o lugar de desenvolvimento de um poder análogo àquele que Spinoza encontrava atrás do exercício por cada ser de seu direito natural” (HOTTOIS, 1993, p 59). Assim, todos os viventes - das bactérias aos animais superiores - possuem algum poder, mas somente o ser humano exerce um poder livre. O poder dos outros seres vivos é um poder cego, que se orienta pelos fins próprios de cada um e que é limitado naturalmente pelas interações com todas as forças dos seres de seu meio, todas igualmente cegas.

É inerente aos seres vivos, como tais, não poderem existir e serem eles mesmos, a não ser destruindo outras formas de vida. As diversas relações das cadeias alimentares, e mesmo o modo de vida dos micróbios revelam que seres vivos asseguram suas subsistência e multiplicação em detrimento de outros seres vivos.

Então, no conjunto diversificado em equilíbrio simbiótico

não há então lugar de condenar o uso que cada ser faz na cegueira de seu poder. Este não é o mal absoluto, mas a condição mesma da existência disto que tende a existir em virtude desta atribuição da natureza que faz de cada ser que ela produz um fim para ele mesmo. (HOTTOIS, 1993, p 60)

Tinland ainda assevera que essa nova responsabilidade do homem não é nada romântica ou sentimental, mas ela é o que transforma a natureza em objeto da ética. Para Tinland, o princípio responsabilidade de Jonas não é uma nem uma releitura das Fioretti franciscanas dos fins da Idade Média, nem do movimento contracultural dos hippies dos anos 60 do século passado (Cf. HOT'TOIS, 1993, p 60).

A Natureza é bem esta na qual nós temos o direito de intervir, e não o jardim que os homens desde o sexto dia da criação teriam na sua guarda e cuidado. Ela é o lugar onde jogam forças antagônicas, onde se desenrola o drama da vida que dá a morte e da morte que abraçam a vida. (HOTTOIS, 1993, p 60)

A natureza não é esta mecânica calculável na qual se baseiam os fatos tecnocientíficos. Para compreender a natureza, afirma Tinland, é preciso usar a memória e prestar atenção nas novidades presentes que aumentam a complexidade do mundo e assim antever possíveis futuros. 
"A memória torna-se necessária para a compreensão do novo e a medida de sua irredutibilidade ao passado" (HOT'TOIS, 1993, p 60).

Ao mesmo tempo em que cria as cidades, onde reina a ordem humana por meio da dominação e da exploração da natureza, o ser humano continua impotente em relação à determinação do devir. Por mais desenvolvidas que sejam as tecnologias e as ciências, o futuro é sempre imponderável. A ética e a política precisam cada vez mais incluir em suas preocupações aquilo que ainda não existe. Trata-se mais de manter ou restaurar as condições de vida digna e autêntica para as futuras gerações, e não de criar novas coisas que nunca teriam existido, mas poderiam ser planejadas.

As éticas antigas se apoiavam numa física tanto quanto numa metafísica que reconhecem a diferença antropológica. Esse pensamento, essa teoria da natureza simultaneamente física e metafísica entra em conflito com o mecanicismo cartesiano, armado com suas idéias claras e distintas, e passa a ficar em segundo plano. Embora a reflexão de Jonas com Aristóteles seja complexa e às vezes não muito clara, não é verdade, mostra Jonas, que a compreensão aristotélica do ser seja incompatível com a explicação moderna da natureza, bem como não é verdade que o dualismo cartesiano refute a visão grega! Jonas assevera que as ciências da natureza não nos dizem tudo sobre a natureza (Cf. HOTTOIS, 1993, p 61).

Se para Bacon "o império do homem sobre as coisas não tem outra base senão as artes e as ciências, porque não se pode comandar a natureza senão obedecendo-lhe" (Bacon, Novum Organum, t.I, \129), Descartes, no Discurso sobre o Método, cria um projeto mais arrojado de nos tornar mestres e dominadores na natureza. Conhecendo as forças da natureza nos tornamos mestres e possuidores dela, pensava Descartes.

Tinland argumenta que o perigo descoberto pela ameaça decorrente da radical mudança do agir humano nos dois últimos séculos, expõe simultaneamente os preconceitos a partir dos quais se desenvolveu e consolidou a ação técnico-científica da humanidade sobre o mundo e a superficialidade da ontologia simplificadora, homogeneizante deste modo de agir.

Urge a reflexão sobre uma filosofia da natureza que seja capaz de responder às demandas de nosso tempo, e, por certo, podemos encontrar este tipo de pensamento na proposta jonasiana. Jonas valoriza a busca de uma fundamentação ontológica, pois nosso recente poder tecnocientífico necessariamente desestabiliza a visada antropocêntrica, já que os riscos inerentes à tecnologia moderna mostram o exclusivismo antropológica como um preconceito.

Esta sacudida na consciência que temos de nós mesmos exige uma reavaliação da relação entre o ser humano e a natureza, e certamente nos trará uma nova medida da ontologia. Esta nova medida do que é faz ressurgir um certo tom pré-socrático, pois sustenta que o ser, ou a 
natureza, é uno e dá testemunho de si mesmo. Vale lembrar que na Antiguidade as ciências não eram experimentais, mas contemplativas.

Ora, se o desenvolvido mostra o que estava velado, o explícito mostra o implícito e o acabado revela o que estava contido no gérmen, é preciso reconhecer que a subjetividade do homem mostra a sua natureza (Cf. HOT'TOIS, 1993, p 64).

Tinland assevera que precisamos aprofundar ainda mais a crítica à racionalidade moderna. A filosofia dos tempos modernos baniu a teleologia a priori, e esse abandono não foi resultado da conclusão de uma série de experimentos. Ora, o que explicita por meio de um processo que mostra o que estava em gérmen é a finalidade ela mesma.

O poder dizer "eu" corresponde a uma autoconsciência que torna possível a referência a si mesmo, a capacidade de dizer eu penso, eu desejo, eu sinto.

A finalidade pela qual todo ente se revela como ente a si mesmo - seu próprio fim - pode ser comparada ao pensamento de Spinoza, defensor das causas finais e que valoriza o esforço de todos os entes para inscrever seu próprio ser na duração, na ordem da natureza (Cf. HOTTOIS, 1993, p 65).

Compreende-se melhor, então, a importância do poder tecnológico na sua capacidade reveladora de estruturas profundas da natureza e do ser no mundo humano. Esse poder põe em perigo todo o edifício da natureza tal como ele se constituiu e a aptidão do ser humano de viver humanamente. (HOTTOIS, 1993, p 66)

Com a consciência deste perigo inédito, que marca uma ruptura, devemos observar solidariamente o que surgiu pelo trabalho lento e misterioso dos processos naturais.

É preciso ter noção adequada da medida das novidades que a hegemonia tecnocientífica faz surgir na ontologia. Enquanto a evolução natural ocorre lentamente a partir da modificação de pequenos detalhes, a moderna tecnologia promove mudanças em grande escala numa velocidade estonteante. O curto prazo do agir técnico dos seres humanos vem substituindo a ritmo mais lento dos processos da natureza graças ao imenso alcance do poder causal das nossas máquinas

Segundo Tinland, o enorme descompasso entre esses dois ritmos - o da natureza e o do agir técnico dos seres humanos - traz à tona duas questões: uma se refere ao estatuto da ação humana em relação a esta ontologia que, em seu sentido originário da physis, é também uma fisiologia, e a outra é a articulação do dever-ser no ser.

A afirmação jonasiana de que a natureza não poderia assumir risco maior que deixar existir o ser humano, se relaciona com este ponto, sustenta Tinland. Se há tecnologia, ela repousa na tendência da natureza à diferenciação e à manutenção das diferenças entre os seres, é uma teleologia da individuação, e com essa perspectiva passou a ser possível a existência humana com 
sua subjetividade, sua capacidade de representação e a consciência de si (Cf. HOTTOIS, 1993, p 67).

Existindo o ser humano, é preciso reconhecer que o exercício de seu poder em relação ao mundo vivente é um direito natural. Entretanto, poderíamos concluir que a humanidade atual parece estar cometendo coletivamente o pecado da desmedida, apoiada no culto da subjetividade e do consumismo.

Se a tecnociência se desenvolveu a partir do pensamento baconiano, possivelmente ela tomou seu impulso e invadiu nosso modo de ser e de agir graças ao modo de ser próprio dos seres humanos. Mas os seres humanos não estão confinados nas relações entre os seres vivos que se encontram em equilíbrio na natureza. Esta espécie de liberação do homem permite a projeção de finalidades que estão fora dos automatismos cegos da natureza, o que ao mesmo tempo produz a glória do gênio humano e o risco do perigo desse gênio.

A ideia de progresso infinito se mostra inviável e não temos o direito de apostar nessa possibilidade. É dessa conclusão que surge a exigência ética de uma refundamentação ontológica do dever-ser, a qual Jonas se empenha com afinco. Mas, ele nos adverte, não podemos aceitar a possível abertura de nosso destino para seu próprio fechamento. A resposta dessa questão se relaciona a uma filosofia da natureza que ancora a axiologia numa ontologia e que, segundo Tinland, questiona a medida do privilégio reconhecido ao homem pelo antropocentrismo, mas simultaneamente reconhece que o primeiro imperativo é que a humanidade exista (Cf. HOT'TOIS, 1993, p 69s).

A extrema capacidade de adaptação dos seres humanos lhes permite a existência mesmo em condições muito desfavoráveis e te mesmo indignas. Diante do poder tecnológico que permite aos seres humanos transformar o mundo, seu próprio corpo e seus pensamentos, "só a previsão da deformação do ser humano nos fornece o conceito de ser humano que se quer preservar.

A humanidade compartilha de um fundamento comum com os outros entes, expondo-os a um perigo que acaba por recair nos próprios seres humanos. Nada em nossa tradição ocidental nos preparou para esse risco que se acentua pela concepção de ciência como dominadora da natureza. É preciso reconhecer que há uma espécie de agir da natureza, e isso implica a afirmação dos fins mesmo sem a presença da racionalidade humana.

A existência de seres vivos na natureza testemunha uma teleonomia que atua como um princípio da existência e de sua afirmação. Somente na ação humana há eticidade, graças ao elevado grau de liberdade dos seres humanos, que pode significar o resultado último do trabalho 
teleológico da natureza e que, entretanto, pode tornar-se a causa da destruição graças ao poder que a civilização tecnológica alcançou (Cf. HOTTOIS, 1993, p 70).

A responsabilidade dos seres humanos sobre a natureza e sobre sua própria existência se origina desse poder de destruição que a humanidade alcançou com o desenvolvimento tecnológico e científico.

Professor Tinland questiona se seria suficiente reconhecer a reivindicação de existência imanente a todo ser que é um fim em si mesmo e retoma a questão se ser é melhor que não-ser. Jonas afirma a primazia do ser sobre o nada, atribui valor à existência e, desta maneira, o sim ao ser e o não ao não-ser passam a constituir obrigação ética.

É preciso ainda esclarecer, dar limites e orientações ao desenvolvimento da ciência e da técnica. A humanidade embriagou-se com o poder, há pouco conquistado, e interferimos sem medidas nos equilíbrios da vida. É preciso compreender a autenticidade do ser humano e suas especificidades, e estar consciente de que seu agir escapa às regulações "cegas" da natureza e da vida.

Questionar o domínio do poder técnico-científico e de sua expansão constitui tarefa da responsabilidade, a partir da tomada de consciência daquilo pelo que somos responsáveis (Cf. HOTTOIS, 1993, p 71).

O homem possui extraordinária capacidade de adaptação, e é a "ideia de ser humano", e não as determinações circunstanciais, que distingue as condições humanas ou não-humanas da existência.

A natureza modificada pelo homem - ou "humanizada" é, na realidade, uma natureza alienada, tornada estranha a ela mesma graças a sua apropriação pelo e para o homem. Uma filosofia da natureza que não permita ou que ao menos seja capaz de dar limites a essa humanização será suficiente para evitar que a euforia de alguns séculos industriais custe a destruição de milênios de evolução do mundo.

Esta festa frívola que consumiu e continua a consumir a natureza avassaladoramente não foi partilhada equitativamente e excluiu muitos seres humanos. (Cf. HOTTOIS, 1993, p 72). “A história, felizmente, nunca diz a última palavra" (HOTTOIS, 1993, p 72).

À pouca esperança e a angústia diante da possibilidade real de um mundo transformado à medida dos seres humanos, e, assim, desnaturada, alienada de si, soma-se a desilusão decorrente dos perigos da utopia do progresso, tão bem demonstrados pro Jonas. É preciso pensar na autenticidade do ser humano no horizonte daquilo que o precedeu e que sobreviverá a ele, diz Tinland, que agradece a Jonas por ter dito isso com tanta força (Cf. HOTTOIS, 1993, p 72s). 


\section{BIBLIOGRAFIA}

JONAS, Hans. O princípio responsabilidade: ensaio de uma ética para a civilização tecnológica. Rio de Janeiro: Contraponto \& PUC-Rio, 2006. Tradução de Marijane Lisboa e Luiz Barros Montez.

O princípio vida - fundamentos para uma biologia filosófica. Petrópolis: Vozes, 2004. Tradução de Carlos Almeida Pereira.

HOTTOIS, Gilbert (organização). Aux fondements d'une étique contemporaine - Hans Jonas e H. T. Engelhardt. Paris: Libraire Philosophique J. Vrin, 1993.

TINLAND, Franck. L’homme aléatoire. Paris: Presses Universitaires de France, 1997.

Les hommes face au défi de leur humanité. Paris, 2010. Texto inédito, cedido para esta pesquisa pelo autor. 


\section{A LIBERDADE À LUZ DO PRINCÍPIO VIDA DE HANS JONAS}

Liberty in light of the phenomenon of life by Hans Jonas

Sylvia Valéria Pinheiro Graduanda em Filosofia/UFRJ

Graduada em Direito/UFRJ

RESUMO: A liberdade aparece em Hans Jonas (1903-1993) como diretriz para a compreensão da vida, serve lhe como pilar na formulação de seu Princípio Vida. Ao explorar a relação entre a necessidade natural e a contingência radical, apontando para a estrita hegemonia da lei da causalidade da ação. Apesar da pluralidade de possibilidades, uma vez encetado o caminho, as possibilidades passadas deixam de existir. A Teoria da Evolução de Darwin (1809-1882) revela a contingente interação entre organismo e meio ambiente. Por parte do organismo ocorrem as variações aleatórias e o ambiente atua pela seleção natural. Jonas aplica o conceito de liberdade na tarefa de interpretar a vida e a considera como o seu fio condutor, pois diferentes estágios da substância Vida podem ser compreendidos se tomado por foco a liberdade a ele disponível. O Ser tende a graus cada vez mais elevados de interação, que implicam, evidentemente, em mais possibilidades de liberdade. No entanto esta liberdade está imbricada com a necessidade do Ser que urge por satisfação. Assim, se conforma um vigoroso movimento dialético: a necessidade demanda uma satisfação do exercício de uma liberdade. Esse binômio se autossustenta, um não existe sem o outro, e nesse movimento incessante o Ser existe. Nas palavras de Hans Jonas, "o poder se transforma em dever quando o que importa é o ser" (JONAS, 2004)

PALAVRAS-CHAVES: Liberdade; Princípio Vida; Hans Jonas. 
A liberdade aparece em Hans Jonas (1903-1993) como diretriz para a compreensão da vida, serve the como pilar na formulação de seu Princípio Vida. Os matizes com que a liberdade se apresenta tecem o fino entendimento das diversas manifestações de vida em todos os seres, até a culminância da expressão da vida no ser humano. O presente texto buscará seguir esse fio pela tessitura da obra Princípio Vida do autor.

\title{
TEORIA DA EVOLUÇÃO
}

A cosmologia de Newton-Laplace, graças a revolução copernicana - que mostrou não haver ponto privilegiado no universo -, revelou em suas equações e fórmulas uma relação entre a necessidade natural e a contingência radical, apontando para a estrita hegemonia da lei da causalidade da ação.

As coisas e os eventos para serem eles mesmos só poderiam ocorrer da maneira que ocorreram. Apesar da pluralidade de possibilidades, uma vez encetado o caminho, as possibilidades passadas deixam de existir:

\begin{abstract}
Embora tudo quanto acontece nesta interação seja governada pela lei da causalidade, as estruturas resultantes são metafisicamente contingentes: nenhuma delas realiza um fim especial da realidade, uma vez que na aritmética das grandezas que se adicionam umas às outras a realidade não tem nenhuma preferência interna por este resultado em comparação com qualquer outro. Portanto a necessidade extrema desta soma é o correlato da mais radical das contingências de todo ser particular. Se algumas das condições iniciais tivessem sido diferentes, o sistema solar não existir, ou teria uma composição diferente da que efetivamente tem, e a completude da natureza como sistema em equilíbrio não sofreria prejuízo. (JONAS, 2004, p 59)
\end{abstract}

A Teoria da Evolução revela a contingente interação entre organismo e meio ambiente: cada um detém uma parcela do ser que veio-a-ser, o primeiro pelas variações aleatórias de suas escolhas de interação e o segundo pela seleção natural dessas escolhas.

A eventual liberdade do organismo de escolher não interagir com o meio, implicaria em ausência de vida. Assim, a vida demanda, necessariamente, interação com o meio. Por outro lado, a interação, que se viu ser contingente à vida, não garante a sua manutenção, pois o meio, pela seleção natural, pode rejeitar a escolha do organismo.

Somente por um enfoque analítico mnemônico se podem verificar as diversas possibilidades que antecederam a escolha determinante de um ser atual. As liberdades das ações 
pretéritas daquele ser, se exercidas de outra forma provocariam a ocorrência de outro ser diverso do atual e, portanto, e implicaria na não existência do ser atual.

A liberdade de escolha do organismo é infinita, mas só algumas delas serão capazes de mantê-lo na vida, na forma que ele se encontra.

\section{LIBERDADE DIALÉTICA}

Liberdade é o fio condutor da vida. Os diferentes estágios da Vida podem ser compreendidos se tomado por foco a liberdade a ele disponível.

Hans Jonas remonta a um termo a quo da vida, um marco zero, onde a substância se imbui de um vir-a-ser-em-si saltando para o mundo das substâncias vivas, motivada por uma incipiente interioridade "pré-histórica" da vida:

Uma vez que a vida, tendo interioridade e finalidade, originou-se do substrato material do mundo, tais qualidades não lhe podem ser estranhas em sua essência; e se não o podemos em sua essência, então (aqui o argumento tornase cosmogônico) também não o podemos em sua origem: já desde a matéria em formação na explosão primordial deve ter estado presente a possibilidade da subjetividade - a dimensão interior em latência, que esperou sua oportunidade externa no cosmos para se manifestar. Algumas conjecturas vão além disso e tentam pensar essa própria "espera" (entendida, por exemplo, como uma "aspiração"), que participa no desenvolvimento das condições físicas para o seu cumprimento, algo como uma teleologia secreta presente em meio à colossal predominância das coincidências mecânicas na pré-história cósmica da vida. Nessa mesma direção, eu mesmo também formulei a conjectura cosmogônica de um fator "desejante" orientado por fins como estando já presente na origem primordial das coisas. (JONAS, 2010 p. 40)

Desse ponto em diante as liberdades se somam e se tornam cada vez mais amplas, perfazendo um efeito cumulativo, umas sobre as outras, sempre se ampliando.

Assim, Jonas aplica o conceito de liberdade na tarefa de interpretar a vida, que é o mister de sua obra.

O Ser tende a graus cada vez mais elevados de interações com o meio, que significa um número cada vez maior de possibilidades, as quais implicam, evidentemente, em mais possibilidades de liberdade. No entanto esta liberdade estána necessidade do Ser que urge por satisfação. Assim, se conforma um vigoroso movimento dialético: a necessidade demanda para uma satisfação do exercício de uma liberdade. Esse binômio se autossustenta, um não existe sem o outro, e nesse movimento incessante o Ser existe, ese faz Forma Viva.

Nas palavras de Hans Jonas, "o poder se transforma em dever quando o que importa é o ser" (JONAS, 2004, p 107) 


\section{O SI-MESMO E O MUNDO}

A vida se apossa de substâncias (substratos) e as liberta no mundo, se fazendo Forma Viva. Esta seria a primeira liberdade ontológica.

Assim, a Forma Viva está livre ela não se identifica com o substrato que a libertou do mundo e que passou a constituí-la.

A existência da Forma Viva depende da matéria, a qual está no mundo, a vida necessita da matéria para se manter na forma, ela necessita possuir o mundo, continuadamente (Necessidade Biológica).

Liberdade ontológica (liberdade formal da matéria) e necessidade biológica conformam dois pólos de uma espiral cada vez mais ampla onde uma se lança a outra, numa dinâmica que possibilita tornar o mundo presente em si. Esta transcendência da necessidade sobre a matéria, aponta para um fora:

Neste autotranscender através da condição de necessidade fundamenta-se a transcendência essencial de toda vida, que nos estágios mais elevados lhe abre um mundo cada vez mais amplo. O ser-dependente indica o campo de suas possíveis realizações, desta maneira criando a intencionalidade como caráter básico de toda vida. (JONAS, 2004, p 109)

"A identidade de si mesmo é um caráter ontológico dos seres vivos sempre em exercício diante da contínua modificação da matéria" (MOURA, 2012, p 36). Esse processo se dá primordialmente pelo metabolismo.

\section{AMPLIAÇÃO DA LIBERDADE}

Jonas analisa a relação dos sentidos físicos com a liberdade. Quanto mais refinados os sentidos, maior o ângulo de liberdade do organismo. A visão é o sentido de excelência das Formas Vivas e no ser humano é a condição de possibilidade de sua evolução espiritual na medida em que enseja a produção de imagens. Segundo Jonas, a capacidade imagética apresenta três características: "1) simultaneidade na apresentação de uma variedade, 2) neutralização da cauda da afecção do sentido, 3) distância no sentido espacial e espiritual” (JONAS, 2004, p 160).

Simultaneidade está na imediata apreensão pelo sentido da visão de tudo que é visto em um abrir de olhos. A parcela do mundo avistada se presentifica em todas as suas nuances num átimo, apartado do tempo. Nenhum outro sentido se liberta dos grilhões da dimensão temporal como a visão, pois os demais sentidos dependem do corpo ser afetado por um período de tempo para que ocorram.

A sensação tem que se prolongar, para com seu fluir adicionar a sequência àquilo que foi iniciado no que antecede (...) $\mathrm{O}$ som existe como sequência, cada momento dele desaparece no que já passou enquanto ele continua a doar (...) 
No caso do tato a situação é semelhante, só que aqui a sucessão é mais um processo de realização ativa do que uma mera recepção passiva de dados" (JONAS, 2004, p 168).

A dimensão temporal é apropriada pela visão, na medida em que "na presença visível de objeto, o espectador pode repousar e desfrutar de um agora ampliado" (JONAS, 2004, p 168) e apenas pela modificação do conjunto visado que novamente ele é fisgado pelo tempo.

Além disso, soma-se ao valor da simultaneidade da visão, a possibilidade da mirada de um mundo externo "ainda sem comunicação com o ser vivo" que habilita o animal a escolher o seu agir, constituindo enorme vantagem nesse caleidoscópio das interações com o meio ambiente.

A segunda característica da visão, neutralidade das causas da afetação dos sentidos, é de importância ímpar considerando que o arcabouço do pensamento jonasiano está na radical aplicação da lei da causalidade da ação. Dessa forma, um sentido que propicie ao ser se manter fora desta lei, ou pelo menos retardá-la, constitui outra enorme vantagem. $\mathrm{Na}$ visão, o ver não atinge o objeto visto, nem demanda nenhuma modificação na situação vista:

Eu não preciso fazer outra coisa senão olhar - sem que por isso o objeto seja tocado; e tão logo haja luz, o objeto só precisa estar aí para tornar-se visível e eu não sou tocado por isso: e no entanto meu estar-em-mim o percebe no seu estar-me-si, ele me está presente sem que me atraia para sua presença (JONAS, 2004, p 170).

A terceira característica da visão, apontada por Hans Jonas, o distanciamento espacial, dessa tríade relaciona mais amiúde com a anterior, pois, quanto mais distante, mais neutra a visão se dá. Além disso, a boa visão exige o distanciamento correto, o que varia de acordo com o objeto visado.

Por outro lado, ainda que a visão seja eminentemente estática, paradoxalmente, o movimento está enraizado em sua origem. Não só quanto ao evidente movimento muscular que ela demanda (retração e distensão do aparelho ótico, movimento do globo ocular), mas na “dependência da perspectiva ótica em relação a locomoção” (JONAS, 2004, p 179).

Graças às experiências de movimento que o ser humano empreende no mundo, ora seguindo em uma ou outra direção, ora avançando ou recuando, interagindo o seu próprio corpo com os corpos do mundo, ele cria "autoperpecção cinestésica" da atividade motora que o guia nas sucessivas construções de distância.

Desta forma aparelhado, o ser humano pode, efetivamente, se entregar ao deleite contemplativo, livremente:

Uma vez de posse do conhecimento que me foi deixado por estas experiências de movimento, eu também posso efetivamente observar o mundo a partir de minha posição de repouso, e compreendê-lo em perspectiva e na ordem de suas diferentes direções. Então eu posso ser o observador estacionário e inativo, que deixa o espetáculo do mundo desfilar diante de seus olhos como em uma tela (JONAS, 2004, p 180). 
Enquanto os vegetais estão adstritos ao que lhes é sensível pelo tato, os animais dispõem de um aparelho sensorial muito mais amplo. Jonas eleva a mobilidade à condição de máxima importância dos sentidos:

E o exemplo do sentido que parecer ser o mais livre de tal mistura mostra que a mobilidade, que é necessária para o próprio exercício da percepção sensitiva, participa, por sua vez da experiência básica da sensibilidade, na medida em que está deve ser mais do que um mero registro de estímulos exteriores (JONAS, 2004, p 180).

O movimento confere o atributo da liberdade aos sentidos. $\mathrm{O}$ animal ao escolher se movimentar para uma direção ou outra, parar ou voltar, escolhe como e quais sensações desejam se afetar.

\section{LIBERDADE DA IMAGEM}

Assim como o movimento, a imagem é produzida em uma escala muito maior do exercício da liberdade. "A linguagem e a capacidade simbólica são modos de ser exclusivos do ser humano" (MOURA, 2012, p 36). A imagem presentifica no homem a ausência, é a presença imagética do fisicamente ausente (cf. MOURA, 2012, p 36).

A imagem é diferente da coisa imaginada, sob pena de perder seu status de imagem e passar a ser a própria coisa ou outra coisa. Portanto, em cada passo na construção da imagem o homem escolhe o que será omitido e quais elementos serão representados.

Hans Jonas associa a capacidade imagética a primazia do sentido da visão, constituindo uma maneira de ser dá visão.

Destarte, o homem se sobressai da totalidade nos organismos vivos, por fazer a junção desses foi atributos: movimento e imaginação. O movimento é orientado pela imaginação e essa dinâmica revela a maior liberdade da espécie humana.

\section{CONCLUSÃO}

Por tudo, se pode dizer que a liberdade é um agir para fora de si, seja para se apropriar do que está fora, seja para alterar o que está fora, o mundo.

A liberdade é facilmente percebida como uma contraparte da necessidade desde o mais simples dos organismos. O metabolismo é o mais simples exercício dessa liberdade. O comer e o excretar são exercício da liberdade absolutamente contingente. 
A filosofia de Jonas parece afirmar que a Vida está em constante busca por liberdade, ideia que ele corrobora com a Teria Evolucionista de Darwin.

No entanto, a cada ampliação do diâmetro do arco da liberdade, surge o incremento proporcional da necessidade. E um organismo necessitado é um organismo frágil.

Assim, o homem aparece como o mais livre e o mais frágil de todas as espécies.

Essa flagrante fragilidade do homem, talvez seja o que acarreta a enorme produção cultural e tecnológica e as tensões pessoais entre si e as demais espécies.

A força motriz do agir do homem está assentada nessa busca incessante de suprir a necessidade pelo exercício da liberdade. Nas palavras pulsantes de Nietzsche:

Exigir da força que não se expresse como força, que não seja um quererdominar, um querer-vencer, um querer-subjulgar, uma sede de inimigos, resistências e triunfos, é tão absurdo quanto exigir da fraqueza que se expresse como força (NIETZSCHE, 2009, pp 32-33). 


\section{BIBLIOGRAFIA:}

JONAS, Hans. O Princípio Vida. Petrópolis: Vozes, 2004.

JONAS, Hans. Matéria, Espírito e Criação. Petrópolis: Vozes, 2010.

MOURA, Sarah. Sobre a Filosofia da Vida, de Hans Jonas. Rio de Janeiro: UFRJ, 2012. (Monografia de Graduação).

NIETZSCHE, Friedrich. Genealogia da Moral. São Paulo: Companhia das Letras, 2009. 


\section{O GNOSTICISMO ANTIGO E O EXISTENCIALISMO CONTEMPORÂNEO: DUAS VERSÕES DO NIILISMO SEGUNDO HANS JONAS}

Ancient Gnosticism and contemporary Existentialism: two versions of nibilism according to Hans Jonas

\section{Thiago Vasconcelos}

Doutorando em Filosofia pela PUCPR

RESUMO: Este trabalho pretende apresentar algumas das ideias de Hans Jonas presentes em sua análise sobre a relação entre os movimentos gnósticos da Antiguidade Tardia e do existencialismo heideggeriano a partir da tese de que ambos compartilham um caráter niilista. $\mathrm{O}$ niilismo que atravessa e constitui o niilismo gnóstico e o niilismo existencialista é caracterizado, para Jonas, pela ruptura do humano em relação à natureza e a consequente desvalorização dessa última. Enfrentar o niilismo consiste, então, na filosofia de Hans Jonas, pensar um novo modo de compreensão dessa relação. Se as duas versões do niilismo estudadas por Jonas, a saber, o gnosticismo e o existencialismo heideggeriano, são marcadas por posicionar o humano à parte do mundo, Jonas, ao contrário, o entende como parte do mundo. Pode-se afirmar, nesse sentido, que o enfrentamento do niilismo constitui a tarefa basilar da filosofia jonasiana.

Palavras-chave: Hans Jonas; Niilismo; Gnosticismo; Heidegger.

\section{INTRODUÇÃO}

Podemos afirmar que o niilismo é um tema nevrálgico no percurso do pensamento de Hans Jonas. O filósofo em vários momentos de sua produção dialoga com aquele que Nietzsche descreveu como o mais perturbador de todos os hóspedes ( $c f$. NIETZSCHE, p. 1999, p. 429). Segundo Avishag Zafrani, o pensamento de Jonas articula-se a partir de uma vontade de refundar a ética contemporânea e de juntamente superar o niilismo (cf. ZAFRANI, 2014, p. 123). A questão que se impõe diz respeito ao modo como o pensador judeu-alemão entende o niilismo, e as diferentes etapas em que dialoga a partir dessa noção.

Podemos situar a articulação de Jonas em torno da problemática do niilismo em três momentos: a) a construção de um "princípio gnóstico" (cf. FOSSA, 2014) caracterizado por um niilismo acósmico; b) o reconhecimento de uma afinidade entre a filosofia da existência, 
sobretudo, heideggeriana e o niilismo gnóstico a partir da questão do dualismo e c) o enfrentamento do niilismo dualista contemporâneo (enquanto vazio de indicação para a práxis humana e desvalorização da natureza) proposta na ontologia da vida e no princípio responsabilidade. Consequentemente, parece-nos que a articulação dualismo e niilismo constitui peça chave para lançar luz em direção à unidade e totalidade do pensamento jonasiano. Este trabalho pretende, desse modo, esboçar algumas notas sobre a análise jonasiana do caráter niilista que aproxima os movimentos gnósticos da Antiguidade Tardia e o existencialismo heideggeriano.

\section{HANS JONAS E O DISTANCIAMENTO DA FILOSOFIA HEIDEGGERIANA}

Jonas, já no início de Gnose, existencialismo e niilismo afirma que seu escopo consiste em experimentar uma comparação entre dois movimentos distantes no espaço e no tempo, "e que à primeira vista parecem incomensuráveis" (PV $\left.{ }^{1}, 233\right)$. O filósofo postula que existe alguma coisa em comum entre os movimentos gnósticos da Antiguidade Tardia e o existencialismo contemporâneo.

A tomada de posição em relação ao existencialismo, e aqui, sobretudo, aquele de vertente heideggeriana liga-se à tomada de distância do pensamento do filósofo de Ser e Tempo por parte de Jonas. Como o próprio Jonas afirma: "Depois da guerra minha reflexão se desenvolveu principalmente sob o signo do distanciamento do existencialismo heideggeriano" (M, 323). É a aproximação de Heidegger ao nazismo que exerce em Jonas o sentimento de "falência do pensar filosófico" (M, 324). A crítica de Jonas a Heidegger aparece, no entanto, não apenas no artigo já citado, mas podemos indicar ainda a conferência intitulada Heidegger e a teologia em um congresso na Drew University de New Jersey sobre os problemas da hermenêutica e o papel do pensamento tardio de Heidegger na linguagem da teologia evangélica ${ }^{2}$. Sobre a filosofia tardia de Heidegger, Jonas afirmou em uma postura fortemente crítica:

Quanto ao Ser de Heidegger, é um caso de desvelamento, um acontecimento carregado de destino sobre o pensamento: isso foi o Führer e a chamada do destino alemão sob seu mandato: um desvelamento de algo, sem dúvida, uma chamada do Ser, carregada de destino em todos os sentidos: nem antes nem agora o pensamento de Heidegger forneceu uma norma para decidir como responder a essa chamada [...]. A resposta do próprio Heidegger, para a

\footnotetext{
${ }^{1}$ No presente artigo usaremos as seguintes siglas para a citação das obras de Hans Jonas: M (Memórias); RG (A Religião Gnóstica: A mensagem do Deus estranho e os começos do cristianismo); PV (O Princípio Vida), PL (O Fenômeno da Vida). As abreviaturas são seguidas do número da página conforme a obra que se encontra nas referências.

2 Sobre esse congresso Jonas relata que Heidegger confirmou sua participação, porém no último instante recusou a participar. Por conseguinte, convidaram a Jonas para proferir a conferência inicial, visto que foi um antigo aluno de Heidegger e Bultmann. Jonas considera esse momento como uma possibilidade de acerto de contas com Heidegger (cf. M, 328-329).
} 
vergonha da filosofia está registrada, e espero que não esquecida: "Que as doutrinas e 'ideias' não sejam as regras do vosso Ser. O Führer e somente ele é a presente e a futura realidade alemã e a sua lei. Aprender a conhecer cada vez com mais profundidade: de agora em diante tudo exige decisão, e toda ação, responsabilidade, Heil Hitler" (PL, 247).

Não podemos, todavia, ignorar a importância da influência exercida por Heidegger sob Jonas, principalmente no tocante à sua análise dos movimentos gnósticos. A analítica existencial do Dasein heideggeriana, bem como a análise epocal do professor de Freiburg ${ }^{3}$, apresenta-se como pano de fundo em que Jonas acredita ser possível analisar diferentes períodos históricos. Segundo Jonas, as estruturas originárias do Dasein em sua relação concreta com ele mesmo e com o mundo identificadas por Heidegger são estruturas a-históricas comuns a todas as épocas. Portanto, são essas estruturas que guiam as relações do Dasein que Jonas toma em suas pesquisas sobre o gnosticismo, a fim de, por meio dessas ferramentas hermenêuticas, lançar luz sobre as objetificações que aparecem dentro de um horizonte histórico-concreto e, então, compreender as razões e interesses implicados na dinâmica da vida em sua relação com tais fenômenos e não outros ( $c f$. BONALDI, 2006, p. 16). Jonas com o passar dos anos se afasta dessa perspectiva que toma a analítica existencial do Dasein como aplicável a todas as épocas históricas, ou seja, como chave que pode abrir todas as portas. Jonas passa a suspeitar "que a analítica existencial, ao contrário de ter revelado estruturas ontológicas universais, foi bem-sucedida para penetrar tão profundamente no universo gnóstico pelo simples fato de ser, de algum modo, já relacionada com a específica disposição (Stimmung) dualista e niilista deste último” (cf. TIBALDEO, 2009, p. $38)$.

A formulação de um princípio gnóstico marcado por um dualismo niilista colabora na compreensão de Jonas do sentido do niilismo moderno. E assim, se anteriormente o existencialismo heideggeriano serviu a Jonas para interpretar o gnosticismo, por último é a utilização do que chamamos de princípio gnóstico que o fornece uma leitura gnóstica do existencialismo. O primeiro passo, portanto, consiste em compreendermos de que trata o princípio gnóstico niilista e os traços constitutivos do movimento gnóstico que dá unidade à multiplicidade de vozes gnósticas.

\section{O NIILISMO GNÓSTICO}

Jonas assinala quatro características comuns a todos os movimentos gnósticos: a) são todos de natureza religiosa; b) todas as correntes estão ligadas à noção de salvação, a religião

\footnotetext{
${ }^{3} \mathrm{Na}$ medida em que podemos afirmar que a análise epocal encontra-se prefigurada em Ser e Tempo.
} 
desse período é uma religião de salvação; c) todos carregam uma concepção totalmente transcendente, ou melhor, transmundana de Deus e d) todos tem uma noção transcendente e ultramundana do objetivo da salvação. Todos esses traços são ligados e engendrados por um dualismo radical dos âmbitos do ser - Deus e mundo, espírito e matéria, corpo e alma, luz e escuridão, bem e mal, vida e morte. O gnosticismo evidencia uma polarização radical da existência que não afeta somente o ser humano, mas a totalidade da realidade. Em suma, o princípio ou paradigma gnóstico pode ser dito nos seguintes termos: “a religião geral do período é uma religião salvífica, dualista e transcendente" (grifo do autor) (RG, 66).

$\mathrm{O}$ traço comum da atitude gnóstica que confere unidade às suas diferentes manifestações é o dualismo radical que o atravessa. Há um dualismo entre o ser humano e mundo, mas, paralelamente a esse, também o dualismo entre mundo e Deus. Segundo Jonas, trata-se de "um dualismo não de grandezas complementares, mas sim de grandezas contrárias” (PV, 239). O mundo é o elemento que separa o ser humano de Deus, pois o "divino é estranho ao mundo e não tem nenhuma parte no universo físico" (PV, 239). O verdadeiro Deus é o absolutamente transmundano, o desconhecido. Desse modo, o mundo não o revela nem o aponta, é totalmente alheio a Deus. O aspecto antropológico toma o ser humano como tripartido, composto de corpo, alma e espírito. Enquanto o corpo e a alma são produtos dos poderes cósmicos e, portanto, estão submetidos às leis deste mundo o espírito ou pneuma "não é parte do mundo, não pertence à criação e ao domínio da natureza" (PV, 239), ele, do mesmo modo que o Deus desconhecido, não pode ser conhecido a partir de categorias mundanas.

A análise das fontes gnósticas, realizada por Jonas, denota a gnóstica negação de que o mundo seja ordenado para o bem, ao ser entendido como a prisão tirânica dos arcontes e sua lei (beirmaméne) constitui-se o inimigo a ser vencido. De acordo com Jonas para os gnósticos "a alienação entre o ser humano e o cosmos devia ser levada ao extremo [...] O mundo tem que ser vencido, e o mundo que se degradou em um sistema de poder só pode ser vencido pelo poder" (PV, 241-242). O gnosticismo é, por conseguinte, um movimento que vê o mundo mais do que como cárcere que devemos nos libertar ${ }^{4}$, mas um inimigo que devemos vencer.

\footnotetext{
${ }^{4}$ A recusa do corpo se dá no platonismo em função da dependência do mundo sensível ao mundo suprassensível. Assim, os valores ligados ao corpo (sensível) estão submetidos aos valores da alma (suprassensível). Em suma, os valores do corpo não podem estar acima dos valores da alma, ao invés, devem se submeter à virtude ao conhecimento verdadeiro. Há na filosofia de Platão uma concepção dualista da realidade que, no entanto, mantém diferenças importantes em relação ao dualismo radical que caracteriza o gnosticismo. É a noção de Ideias que representam no arcabouço do pensamento platônico uma dimensão diversa da realidade, isto é, um plano diferente e, ao mesmo tempo, superior da realidade. Podemos afirmar que é com as Ideias que Platão descobriu o mundo do inteligível como a "dimensão incorpórea e metaempirica do ser. E esse mundo do inteligível incorpóreo transcende o sensível, não no sentido de uma absurda "separação" e sim no sentido da causa metaempírica, a verdadeira razão de ser do sensível” (grifo do autor) (REALE, 2007, p. 78). Por conseguinte, o dualismo platônico não significa uma radical separação do sensível, ao contrário, admite a existência de uma causa suprassensível, a saber, as Ideias, como razão de ser do sensível.
} 
O dualismo gnóstico tem um caráter desmundanizante, que significa a rejeição de qualquer vínculo com o mundo. Recusa-se ao mundo pelo uso excessivo ou pela abstinência. E no gnosticismo o elemento aprisionador do mundo e do corpo torna-se mais radical por causa da violência com que somos nele lançados e com a qual também temos de dele nos libertar.

Perguntamo-nos então em que medida Jonas encontra possíveis pontos de encontro entre o gnosticismo e o pensamento moderno e, principalmente, o existencialismo heideggeriano. A proposta de tal comparação não significa, contudo, que Jonas assume o princípio gnóstico como a-histórico e, assim, ignora o contexto em que o gnosticismo surgiu e se desenvolveu. Podemos dizer que o existencialismo é "quase gnóstico, gnóstico entre aspas: não é o verdadeiro, autêntico fenômeno, mas algo que, sobre a base de específicas condições histórico-espirituais levou a algo comparável” (BONALDI, 2005, p. 155). Desse modo, Jonas não exclui a possibilidade de reconhecer alguns elementos comuns. Aqui vamos centralizar a discussão em torno de dois aspectos: a) o antinomismo antigo e moderno e a indiferença da natureza.

\section{O NIILISMO HEIDEGGERIANO E SUAS RELAÇÕES COM O GNOSTICISMO ANTIGO}

O antinomismo gnóstico é caracterizado pela negação do caráter objetivo da Lei, ou seja, o pneuma cuja natureza é alheia a esse mundo não tem qualquer relação normativa com o mundo. O Deus gnóstico entendido como totalmente outro e desconhecido é uma concepção niilista, pois dele não parte qualquer lei para a natureza e, por conseguinte para o ser humano. O antinomismo gnóstico não é marcado pelo relativismo, mas pela visão gnóstica do mundo, isto é, o desprezo pelo mundo por meio da prática libertina ou ascética, sendo que, uma renuncia a seguir a natureza pelo excesso e a outra pela abstinência. Segundo Jonas, "a partir desta raiz podese ver que para o gnóstico, na renúncia a toda a norma [...] estava em jogo um interesse metafísico positivo: é a afirmação da autêntica liberdade do eu" (PV, 246).

Nietzsche apresentou o sentido do niilismo a partir da afirmação da morte de Deus. Nesse sentido, a raiz da situação niilista refere-se à desvalorização dos valores supremos e, consequentemente, a perda da possibilidade de valores obrigatórios em si. Jonas cita a interpretação que Heidegger faz da expressão nietzschiana Deus está morto ${ }^{5}$ em que essa significa que o mundo suprassensível não tem mais força operante.

\footnotetext{
5 "Para onde foi Deus? gritou ele [o homem louco], já lhes direi! Nós o matamos - vocês e eu. Somos todos seus assassinos! Mas como fizemos isso? Como conseguimos isso? Como conseguimos beber inteiramente o mar? Quem nos deu a esponja para apagar o horizonte? Que fizemos nós, ao desatar a terra do seu sol? Para onde se move ela agora? Para onde nos movemos nós? [...] Não sentimos na pelo o sopro do vácuo? [...] Não sentimos o cheiro da
} 
Mas, segundo Jonas, em que consiste o antinomismo do pensamento heideggeriano? É a recusa de toda natureza definível do ser humano que possa submeter sua existência a uma essência pré-determinada. Há em Heidegger, seguindo a interpretação jonasiana, a concepção de uma existência transessencial, isto é, que se autoesboça livremente. E, “o que não tem natureza não tem norma, só o que pertence a uma ordem da natureza [...] é que possui uma natureza. Só onde existe um todo é que existe uma lei” (PV, 247). A não identificação entre Ser e fundamento indicada por Heidegger em Ser e Tempo permite afirmar que do Ser não se desdobram valores fundantes, isto é, um nomos, aliás, os valores se estabelecem como projetos da vontade, ou seja, “o valor não é mais percebido na contemplação do ser objetivo, mas colocado como um ato de valor atribuído" (PV, 236). É nesse sentido que Jonas vê semelhanças com o conceito gnóstico da negatividade trans-psíquica do pneuma não mundano, pois o pneumático "não pertence a nenhuma ordem, está acima da lei, além do bem e do mal” (PV, 248).

O dualismo entre ser humano e physis consiste no pano de fundo da situação niilista. Que se traduz na impossibilidade de encontrar no mundo qualquer fundamento para a ação, mas também na relação que se estabelece entre ser humano e mundo. Jonas retorna à afirmação de Pascal $^{6}$ - "Tragado pela amplidão dos espaços infinitos, de que eu nada sei e que nada sabe de mim, eu estremeço" - para mostrar que a solidão do ser humano no todo da realidade deve-se, sobretudo, ao silêncio, isto é, à indiferença do universo em relação ao ser humano. É na mudança da imagem da natureza, ou seja, do ambiente cósmico do ser humano que se encontra o pano de fundo que conduz ao existencialismo moderno.

A indiferença da natureza significa que ela não tem qualquer relação com fins e objetivos, desse modo recusa-se a teleologia. A natureza não sanciona qualquer finalidade humana possível. O sentido ou o valor não pode mais ser encontrado na contemplação do ser objetivo, ao contrário, é um ato de valor que se atribui, ou seja, uma função da vontade. Portanto, a total falta de sentido de um universo indiferente ao valor não fornece qualquer indicação para a ação humana.

Enquanto o gnóstico foi lançado em uma natureza contrária a Deus e, consequentemente, contrária ao ser humano, o ser humano moderno foi lançado em uma natureza indiferente ao valor e a finalidade. À natureza neutra não se confere ao menos a qualidade de antagônica, dela não se pode obter qualquer orientação, o que torna

putrefação divina? Também os deuses apodrecem! Deus está morto!” (grifo do autor) (NIETZSCHE, 2012, p. 137138).

${ }^{6}$ De acordo com Jonas, seguindo Karl Löwith, Pascal poderia ser assinalado como o primeiro existencialista, mas também como o último gnóstico. Segundo Jonas, a afirmação pascaliana da solidão humana em um universo estranho sintetiza a solidão do ser humano frente ao mundo que caracteriza o gnosticismo a partir da noção de Vida estrangeira, assim como a noção de estrangeiro presente no existencialismo contemporâneo. 
o niilismo moderno muito mais radical e desesperado do que jamais poderia ter sido o niilismo gnóstico, com todo o seu horror ao mundo e sua revolta contra as leis do mundo. Que a natureza não se preocupe, é este o verdadeiro abismo. Que só o ser humano se preocupe, não tendo diante de si, em sua finitude, outra coisa a não ser a morte, que ele esteja só com sua contingência e com a ausência objetiva de sentido de seus projetos de sentido, é na verdade uma situação sem precedentes (PV, 252).

Os traços identificados por Jonas dessa situação da interpretação moderna acerca da natureza apresentam-se no enfoque da filosofia heideggeriana em que a natureza perde seu caráter criador e autônomo para assumir "o caráter de mera estrutura existencial, 'relativa a um Dasein histórico" (RODRÍGUEZ, 2001, p. 225). Além disso, notou Lawrence Vogel que "Jonas aceita o ponto de vista de Karl Löwith segundo o qual não há lugar para a natureza como possuindo valor intrínseco na ontologia fundamental de Heidegger" (VOGEL, 1995, p. 59). Segundo Jonas, na tentativa heideggeriana de superar o dualismo cartesiano a natureza continua carecendo de valor próprio. E, em vista disso, não há qualquer sentido em se preocupar com aquilo do qual não decorre qualquer sanção. A relação que o ser humano emprega em um mundo desprovido de valor e finalidade é "uma relação de poder, o domínio" (PV, 237). Segundo o filósofo, o existencialismo compartilha com a ciência moderna essa desvalorização da natureza que é deixada ao domínio humano.

Esta desvalorização existencialista da natureza é manifestamente um reflexo do seu esvaziamento espiritual pela ciência natural moderna [...] Nunca uma filosofia preocupou-se tão pouco com a natureza quanto o existencialismo, para quem ela não conservou nenhuma dignidade (PV, 250).

A possibilidade de enfrentamento do niilismo em Jonas se dá, desse modo, a partir da tarefa de repensar a compreensão do fenômeno da vida e, por conseguinte, de refundar a ética contemporânea. Essa tentativa de enfrentar o niilismo visa romper com quatro características do sistema gnóstico niilista que aparecem, segundo Jonas, também no existencialismo e em Heidegger: a) o dualismo radical homem-mundo, b) a total falta de relação e afinidade entre logos humano e logos mundano, c) a contingência da posição humana que é incompreensível para si mesma e d) a indeterminação de uma atitude prática (cf. BONALDI, 2005, p. 158). Em suma, aceitar o desafio niilista significa

repensar a noção de totalidade do ser, vale dizer, da natureza, da physis no interior da qual o ser humano não se sinta estrangeiro, mas possa por um lado reconhecê-la como tal e, por outro lado, seja capaz de fornecer indicações 
obrigatórias à sua prática, isto é, na qual seja possível identificar perspectivas de significado e valor (BONALDI, 2005, p. 159).

Podemos afirmar, então, que na interpretação jonasiana, a filosofia elaborada por Heidegger participa da concepção em que não se pode obter nenhuma orientação da natureza. Por isso, o existencialismo constitui uma filosofia que deve ser enfrentada em seu traço fundamental, qual seja, o niilismo, cuja expressão é a negação da finalidade e do valor intrínseco à natureza. O existencialismo contemporâneo revela, destaca Jonas, a profundidade do niilismo moderno: o discurso do ser-lançado ao mundo é um resquício de uma metafísica dualista, fornecida pelo quadro geral da interpretação da natureza pela ciência natural moderna: se o ser humano foi lançado à natureza de maneira cega, "então o que vê é produto do que é cego, o que se preocupa é produto do despreocupado, uma natureza teleológica foi produzida de maneira não-teleológica" (PV, 252). Decorrente disso, o desafio niilista - aquele que afirma que não tem sentido preocupar-se com o que não tem atrás de si nenhuma sanção em uma intenção criadora significa no interior do trabalho de Jonas

repensar a noção de totalidade do ser, vale dizer, da natureza, da physis no interior da qual o ser humano não se sinta estrangeiro, mas possa por um lado reconhecê-la como tal e, por outro lado, seja capaz de fornecer indicações obrigatórias à sua prática, isto é, na qual seja possível identificar perspectivas de significado e valor (BONALDI, 2005, p. 159).

A partir da crítica que Jonas direciona ao niilismo gnóstico e sua ligação com o niilismo do pensamento de Heidegger, e por expansão à modernidade, identificamos que é na relação entre o ser humano e a natureza que o niilismo constitui um perigo a partir de duas perspectivas: a primeira toma a natureza como antípoda (posição anticósmica, isto é, gnóstica), já a segunda entende a natureza como neutra e indiferente (posição acósmica, isto é, existencialista). A tarefa jonasiana de oposição ao niilismo dualista significa a tentativa de enfrentamento das duas posições descritas acima que, em última análise, ocultam a afinidade entre o ser humano e a natureza, o problema central do dualismo. Para Hans Jonas, a separação entre ser humano e natureza é a marca central do niilismo que compreende "a natureza viva como alguma coisa estrangeira ao homem" (MONTEBELLO, 2007, p. 10).

Nessa medida, o fracasso da ontologia de matriz heideggeriana fará com que Jonas se empenhe em uma revisão ontológica que busca interpretar a relação entre o ser humano e a natureza. Sua fenomenologia da vida é, então, uma tentativa de "destruir a hipótese niilista de um isolamento do homem em relação à natureza” (MONTEBELLO, 2007, p. 12). 


\section{CONSIDERAÇÕES FINAIS}

Assim, resta claro que é por meio do conceito de natureza - ao qual anteriormente eram negados dignidade e valor intrínseco - que o filósofo visa restituir o sentido do vivente perdido com o niilismo que atravessa a compreensão moderna de natureza e ramifica-se no existencialismo contemporâneo que acaba por não se destacar do dualismo metafísico cartesiano. Jonas vê no niilismo dualista um problema filosófico que se dimensiona como problema da vida e empenha-se, decorrente disso, na reinterpretação da natureza da vida, buscando compreendê-la como uma totalidade orgânica, psíquica e espiritual. Jonas não deixa de reconhecer, contudo, o caráter dual e dinâmico da vida, ou seja, ele não abole a noção de dualidade, mas não recai por isso em um dualismo.

Nessa reformulação do problema do Ser entendido como Ser vivente, Jonas pretende alcançar a superação da visão dualista e, por conseguinte, enfrentar o niilismo, que está na gênese da perda do sentido da vida como uma unidade psicofísica. Revisão ontológica que tem como consequência última a possibilidade de ver o ser humano não como estrangeiro no mundo, mas como parte integrante da totalidade do sentido da natureza, do fenômeno da vida. Eis como Jonas articula a sua tentativa de enfrentamento do niilismo, primeiramente no campo da biologia filosófica e, consequentemente, no da ética dela derivada.

\section{REFERÊNCIAS}

\section{Obras de Hans Jonas}

La religión gnóstica: El mensage del Dios Extraño y los comienzos del cristianismo. Traducción de Menchu Gutiérrez. Madrid: Ediciones Siruela, 2000.

The phenomenon of Life. Toward a Philosophical Biology. Illinois: Northwestern University, 2001.

O princípio vida: fundamentos para uma biologia filosófica. Tradução de Carlos Almeida Pereira. 2.ed. Petrópolis: Vozes, 2004.

Memorias. Traducción de Illana Gines Comín. Madrid: Losada, 2005.

\section{Outras obras}

BONALDI, C. Hans Jonas e il nichilismo: ala ricerca di un paradigma antignostico. In: SORRENTINO, S. (Org.). Nichilismo e questione del senso: Da Nietzsche a Derrida. Roma: Aracne, 2005. p. 149-170. 
, C. Introduzione. L'esistenza svelata: Heidegger, Jonas e S. Paolo. In: JONAS, Hans.

Conoscere Dio Una sfida al pensiero. Traduzione di Claudio Bonaldi. Milano: Edizioni Albo Versorio, 2006. p. 11-21.

FOSSA, F. Il concetto di Dio dopo Auschwitz. Hans Jonas e la gnose. Pisa: ETS, 2014.

MONTEBELLO, P. Vie et phénomène de vie chez Hans Jonas. In: Revue Kairos, Toulouse, n. 23, p. 1-26, 2004.

NIETZSCHE, F. Obras incompletas. Tradução de Rubens Rodrigues Torres Filho. São Paulo: Nova Cultural, 1999.

2012.

, F. A gaia ciência. Tradução de Paulo César de Souza. São Paulo: Companhia das letras,

REALE, Giovanni. Platão. Tradução de Henrique Cláudio de Lima Vaz; Marcelo Perine. São Paulo: Edições Loyola, 2007.

RODRÍGUEZ, A. R. Nihilismo y tecnología: Hans Jonas y la filosofia de la historia. Sapientia, Buenos Aires, v. 56, p. 213-235, 2001.

TIBALDEO, R. F. La rivoluzione ontologica di Hans Jonas: uno studio sulla genesi e il significato di "Organismo e Libertà". Milano: Mimesis, 2009.

VOGEL, L. Hans Jonas Diagnosis of Nihilism: the case of Heidegger. International Journal of Philosophical Studies, v. 3, n.1, p. 55-72, 1995.

ZAFRANI, A. Ernst Bloch et Hans Jonas: Refondation de l'éthique à partir d'une critique du nihilisme. Alter Revue de Phénoménologie, n. 22, p. 123-144, 2014. 


\section{HANS JONAS - CLONAGEM REPRODUTIVA HUMANA E CUIDADO CRIATIVO ${ }^{1}$}

Hans Jonas, buman reproductive cloning and creative care

\section{Wendell E. S. Lopes}

RESUMO: O presente trabalho visa apresentar uma reflexão ética sobre uma das mais intrigantes biotecnologias da atualidade: a clonagem reprodutiva humana. Mais especificamente, o objetivo é explorar o sentido da crítica do filósofo Hans Jonas à referida modalidade biotecnológica, derivando dessa crítica um princípio que chamaremos de "Cuidado Criativo" princípio que se pretende uma interdição moral à clonagem reprodutiva humana.

PALAVRAS-CHAVE: Clonagem; Ética; Cuidado criativo.

ABSTRACT: The present paper aims to presents an ethical reflection on one of the most intriguing biotechnologies nowadays: cloning. More specifically, the goal is to explore the meaning of Hans Jonas criticism on cloning, deriving from his criticism a principle which we will call "Creative Care" - a principle that intends to be a moral one prohibiting human reproductive cloning.

KEYWORDS: Cloning; Ethics; Creative care.

Para iniciar este ensaio, permitam-me citar de saída o sempre eloquente Peter Sloterdijk: “imaginariamente, já vivemos hoje em um calendário post Dolly creatam” (2000, p. 107-08) - isto é, em um mundo que tem bem definido para si um antes e um depois de Dolly. O nascimento do mamífero (não humano) mais famoso da história tem sido fonte de forte controvérsia e agitação, haja vista a possibilidade real de aplicação da clonagem para a reprodução humana. Os enredos de tal possibilidade ainda estão por aí a nos espreitar. Naturalmente, sabe-se que a clonagem reprodutiva ainda goza hoje de muitos problemas relacionados à sua eficiência e segurança. Por um lado, o índice de sucessos é baixíssimo - o nascimento de Dolly exigiu nada menos que a cultura de 430 ovócitos de mais de 40 ovelhas, com o resultado de 277 “embriões reconstruídos”, dos quais apenas 29 embriões se desenvolveram normalmente até o estágio de blastocisto, sendo

\footnotetext{
${ }^{1} \mathrm{O}$ seguinte ensaio é a versão revista e ampliada de uma versão preliminar apresentada no "II Colóquio Internacional NEPC: biotecnologias e regulações", realizado na Universidade Federal de Minas Gerais/MG, no dia 29 de abril de 2011.
} 
implantados em 13 ovelhas com um sucesso único: Dolly (cf. GRIFFIN, 2002, p. 284); e mais: os baixos resultados (entre 1 a 4\%) permanecem para todas as espécies (cf. PENNISI \& VOGEL, 2000). Por outro lado, o número de problemas que a técnica apresenta é notável: em todas as espécies (ainda que não em todos os indivíduos) há registros de incidência de anormalidades de extrema severidade. A lista engloba (a) morte prematura (cf. RENARD et al., 1999; KAHN, 2000, p. 225; GRIFFIN, 2002, p. 285), (b) anomalias em longo prazo como problemas respiratórios, hepáticos, renais, imunológicos - existindo relatos, inclusive, de ovelhas com vasos sanguíneos vinte vezes mais largos que o normal (cf. KLOTZKO, 2004, p. 118) e também com o próprio tamanho muito maior que o normal (cf. GRIFFIN, 2002, p. 285), e (c) envelhecimento precoce (cf. KAHN, 2000, p. 226; SHIELS et al., 1999; ALLHOFF, 2004, p. 29). Alguns cientistas - embora não todos - pensam até mesmo que todo clone é defeituoso. Não sem motivos, o consenso atual (na maioria dos países ocidentais) quanto à clonagem reprodutiva humana é a legislação contrária à sua aplicação.

Apesar disso, é certo também que a prospectiva é de aperfeiçoamento da técnica e de seus problemas, ao que já se pode ouvir alguns defenderem que "deveríamos não insistir em um critério que exija riscos que sejam menores do que aqueles que aceitamos para a reprodução sexual, ou em outras formas de reprodução assistida...” (BUCHANAN et al, 2000, p. 199). Tendo em vista principalmente essa última insistência que certamente não é um caso isolado, e partindo de uma situação hipotética, mas bastante plausível, em que a clonagem reprodutiva humana seria segura ou pelo menos aceitável do ponto de vista técnico - ao custo, claro, da experimentação com animais, e, nesse sentido, para desagrado de seus defensores -, buscaremos demonstrar em que sentido a clonagem mesmo em uma situação ideal de temperatura e pressão seria moralmente reprovável. Mais especificamente nosso escopo é explorar o sentido da crítica de Hans Jonas à clonagem, derivando daí um princípio que chamaremos de "cuidado criativo" - princípio este que como uma das facetas da responsabilidade se pretende uma restrição moral à clonagem reprodutiva humana.

Inicialmente, então, devemos começar com Jonas. Do tecido de suas considerações à clonagem duas críticas principais se destacam. A primeira, ele próprio a designa por "crítica existencial". É a ela que irei ater-me primeiro. Para Jonas, a questão ética levantada pela clonagem se refere ao esclarecimento do "que para o próprio clone significa ser um clone" (JONAS, 1974/1980, p. 158; 1985/1987, p. 187). E nessa direção, o que ele busca é uma "certeza transempírica do critério que às vezes concede a contemplação da essência” (JONAS, 1974/1980, p. 158; 1985/1987, p. 187). Devemos então perguntar: qual é a "essência" que, ao ser contemplada, fornece tal certeza? A resposta, podemos ouvir do próprio Jonas: "a questão central 
da essência é aquela da ipseidade sem prejuízo [unprejudiced selfhood/nicht-präjudizierter Selbstheit]" (JONAS, 1974/1980, p. 159; 1985/1987, p. 187). É esse ponto, portanto, o determinante para a comparação do caso do clone com a situação dos gêmeos idênticos. Nessa comparação, o que logo se mostra é a simultaneidade [Gleichreitigkeit] dos gêmeos idênticos, à qual se distingue completamente a desigualdade inerente à condição clone em relação àquele de quem ele é clone uma situação que se estabelece em prejuízo à ipseidade do clone. O problema é exatamente o fato de que, para o clone, “conhecer-se como uma mera cópia de um ser que já se revelou em uma vida anterior deve asfixiar a autenticidade do ser si mesmo e a liberdade de primeiro descobrir a si mesmo... Esse mesmo conhecimento ilícito asfixia a mente-aberta de outrem em relação ao recém e, entretanto, não- tão-recém chegado" (JONAS, 1985/2004, p. 578; 1985/1987, p. 214). É tendo em vista este prejuízo inerente à situação existencial do clone que Jonas vê a necessidade do mandamento moral seguinte: "nunca violar o direito àquela ignorância que é a condição para a possibilidade de ação autêntica; ou: respeitar o direito de cada vida humana de encontrar seu próprio caminho e ser uma surpresa para si mesma” (JONAS, 1974/1980, p. 163; 1985/1987, p. 194).

Com essa breve exposição inicial do primeiro aspecto da posição de Jonas, passo a uma discussão da fortuna crítica que seu argumento existencial encontrou. Tal argumento foi considerado por boa parte dos críticos como bastante promissor e profundo, mas apesar disso não suficiente. Assim se passa primeiro com a crítica de Steinbock. A autora acusa Jonas de cair no que ela chama de "a falácia do determinismo genético". Aos seus olhos, a crítica de Jonas seria a de que dado a sua condição - enquanto distinta à do gêmeo síncrono - o clone "seria incapaz de criar e de se tornar seu próprio Eu [self]" (2000, p. 72 [grifo nosso]). A autora chega a sugerir que a pessoa clonada poderia muito bem ter uma boa idéia de como estaria à idade de cinqüenta anos, mas não teria "as mesmas habilidades e talentos que as de seu progenitor, pois [esses] dependem pelo menos de fatores ambientais tanto quanto da herança genética" (STEINBOCK, 2000, p. 72). Por sua vez, Valk considera que para Jonas "um futuro aberto é uma pré- condição essencial para a criatividade pessoal" e, portanto, fator determinante do "direito [que cada um tem] de encontrar seu próprio caminho na vida" (1997, p. 85). Mas para ele tal posição seria como que a "defesa de uma opção de avestruz" (VALK, 1997, p. 90).

De modo geral, essas duas críticas - que no fundo são complementares - se tornaram regra quando o assunto é o argumento existencial de Jonas. Frente a elas, entretanto, é preciso esclarecer dois grandes equívocos. Primeiro, é bastante claro que Jonas distingue "unicidade [uniqueness] de genótipo" e "unicidade de ser" (cf. JONAS, 1974/1980, p. 160), e isso pela seguinte razão: 
independente de se o 'conhecimento' [quanto à determinação genética] é verdadeiro ou falso (existem razões para se acreditar que essencialmente é falso em si), ele é pernicioso para a tarefa da ipseidade: existencialmente significativo é o que o indivíduo clonado pensa - é impelido a pensar - sobre si mesmo, não o que ele 'é', no sentido substancial de ser. Em suma, ele é antecipadamente roubado da liberdade que apenas sob a proteção da ignorância pode ter êxito (JONAS, 1974/1980, p. 162; 1985/1987, p. 192)2.

Esse primeiro esclarecimento nos leva a outro, e que no fundo é uma resposta à crítica de Valk. O que se deve entender é que "futuro aberto" não é um direito, mas um fato biológico, que tanto mais se acentua quanto mais ipseidade possui um organismo (cf. JONAS, 1966/2001, p. 83-86). A filosofia da biologia elaborada por Jonas defende explicitamente a idéia de que "um organismo também tem uma existência subjetiva [subjektives Dasein]" (JONAS, 1991, p. 106), e nesse sentido um horizonte de transcendência e abertura já se encontra em toda experiência propriamente orgânica. Assim, seu argumento não gravita fundamentalmente em torno do problema da qualidade de vida do clone - o problema não é psicológico, mas ontológico, o que quer dizer que o que conta é a condição existencial como tal, que no caso do clone se encontra prejudicada - e é desigual - já de saída. A questão é o prejuízo no horizonte de abertura, que embora seja, de fato, aberto, não é radicalmente aberto - é isto o que se quer dizer com a afirmação de que a clonagem infringe o "direito à ignorância”, "indispensável para a liberdade existencial" (JONAS, 1985/2004, p. 578; 1985/1987, p. 214) - onde "liberdade existencial", claro, não se confunde com livre-arbítrio (cf. PRUSAK, 2008, p. 321-323).

Esses são, a meu ver, alguns dos elementos mais importantes da crítica existencial. Ao se passar para a outra ponta do argumento de Jonas, encontramos agora a crítica de que a clonagem é "por seu método, a forma de manipulação genética mais arbitrária e ao mesmo tempo, por seu objetivo, a mais escrava" (JONAS, 1974/1980, p. 154; 1985/1987, p. 179), pois ao contrário da "modificação arbitrária da substância hereditária" ela busca um controle fixador em detrimento do acaso da variabilidade. Portanto, ela "não pretende representar uma viagem ao desconhecido, mas justamente em direção ao mais conhecido” (JONAS, 1985/1987, p. 179).

\footnotetext{
2 Algo bem próximo do que salienta Jonas, aqui, parece se encontrar mais recentemente, com um novo tom, no que Holm defende com seu "life in the shadow argument": "o argumento da vida-na-sombra não se baseia na falsa premissa de que podemos fazer uma inferência do genótipo para o fenótipo (psicológico ou relativo à personalidade), mas apenas na premissa verdadeira de que há uma forte tendência pública em fazer tal inferência. Isto significa que as conclusões do argumento se seguem enquanto esta premissa empírica permanecer verdadeira"; e o autor ainda ressalta: "é provavelmente fantasioso esperar uma mudança muito grande nas percepções do público sobre a genética, mesmo que façamos uma campanha extremamente forte de informação pública" (HOLM, 2001, p. 206).
} 
Esse argumento contra a clonagem ficou rotulado como o "argumento da variabilidade" e logo recebeu também críticas dos defensores da clonagem. O argumento dos críticos se reduz em linhas gerais à afirmação de ceticismo quanto a uma grande adesão e difusão da clonagem reprodutiva na esfera pública, o que por sua vez não geraria efeitos tão consideráveis quanto à variação do pool gênico (cf. HARRIS, 1997, p. 356; Singer, 2001, p. 162; KLOTZKO, 2007, p. 131). Não obstante, quero antes fazer notar alguns problemas implícitos a essa idéia: não me interessa tanto, aqui, se, de fato, a clonagem levaria a uma queda considerável da variabilidade genética. Antes, o que gostaria de chamar a atenção se refere ao fato de que esse contraargumento não se baseia em evidências, mas na suposição de que as pessoas evitariam escolher a clonagem por ser esta uma forma pior e mais drástica de ter "filhos". Se é uma opção declaradamente pior - pois do contrário seria necessário dizer que a procura pela clonagem aumentaria - por que então defendê-la? E mais ainda: por que a opção pelo fixar em detrimento da variabilidade? Ou se se preferir: por que a lógica do mesmo em detrimento da lógica da alteridade? À primeira pergunta só se pode responder em termos de custo-benefício. A segunda, por sua vez, deve o ser em termos de reivindicação de um direito específico que precisa responder por sua legitimidade. Ambos os pontos precisam ser tratados.

Tendo explicitado até aqui as duas pontas do argumento jonasiano contra a clonagem e deixando entrevisto os problemas que levanta, posso agora derivar - e defender - o princípio ético que chamo de cuidado criativo. O que ele propõe é apenas que os pais não causem deliberadamente dano existencial/ontológico aos seus filhos, mas antes se baseiem em um paradigma de adoção. Tal princípio possui uma dupla orientação. Vejamos, então, o que está implicado em cada um de seus polos orientadores.

Num primeiro plano, note-se inicialmente que tal principio é antes de tudo um princípio ético antes que propriamente político (como o princípio da "autonomia procriativa) e tem um sentido negativo, isto é, ele não defende primeiramente o que positivamente se deveria fazer (ainda que possua tal orientação complementar também, como veremos), mas antes destaca o que não se deveria fazer ou o que se deveria evitar: não causar dano existencial-ontológico. Nesse sentido, o princípio do cuidado criativo não se identifica também com um princípio da "beneficência procriativa" (SAVULESCU, 2001), pois pede algo muito diferente do que a escolha do melhor (e entenda-se "melhor" aqui no sentido de melhor condição de nascimento) - algo que gera, inclusive, consequências teóricas e práticas absurdas (cf. ALLHOFF, 2004, p. 30-31; e STEINBERG, 2004, p. 27-28). O que nosso princípio pede, ao contrário, ao reivindicar que o direito à ignorância seja preservado é simplesmente uma condição de igualdade antropológica (em termos existenciais-ontológicos). Com esta primeira orientação, ele precisa, entretanto, 
responder a críticas que se baseiam em termos de custo-benefício. Por exemplo, poder-se-ia objetar contra o princípio proposto a afirmação de que uma vida prejudicada é ainda a única possibilidade para o clone e, portanto, de seu interesse, uma vez que não é pior do que não viver de modo algum (cf. HARRIS, 2004, p. 70; SINGER, 2001, p. 164). Mas em resposta é preciso dizer que esse tipo de argumento é uma impostura e expressa apenas o desespero retórico daquele que já reconhece que pratica o pior e ainda busca se justificar com o apelo emotivo a um suposto valor da vida em detrimento do não existir; pior: tal argumento simplesmente justifica trazer à luz monstros, pois, afinal, melhor uma vida de monstro do que vida nenhuma. Trata-se de um exemplo típico de mera santificação indevida dos meios em função de um fim desejado ${ }^{3}$.

Seguindo numa mesma direção, mas com um acento ligeiramente diferente, pode-se ouvir outra crítica. Harris, por exemplo, observa que a pobreza é um prognóstico preciso de maus resultados para a prole, embora seja bem diferente "dizer que não se deveria permitir que o pobre tivesse filhos" (2004, p. 74 e também p. 84-85). Brock, por sua vez, oferece um novo capítulo desse argumento: "os mais possíveis danos para uma criança clonada são menos sérios do que os danos genéticos com os quais os pais podem atualmente permitir que sua descendência seja concebida ou nasça" (1998, p. 145). E Singer (2001, p. 164), por fim, segue o estilo de tal argumento ao sugerir que a aceitação dos riscos no nascimento de um recém-nascido prematuro é idêntica a de um indivíduo clonado. Mas contra essas críticas pode-se dizer junto com Prusak que tais críticas "são exemplos do que se tem acostumado chamar de 'argumento do precedente', especificamente 'o argumento nós já fizemos isso (e tudo está bem)'. Esse argumento tem a seguinte forma: 'se uma prática $\mathrm{X}$ foi moralmente aceita no passado, e se a prática $\mathrm{Y}$ é exatamente igual à prática $\mathrm{X}$, então a prática $\mathrm{Y}$ deveria ser moralmente aceita agora e no futuro"'. O erro fundamental do argumento é, como se percebe, comparar exemplos que simplesmente não são análogos, isto é, a prática $\mathrm{X}$, a clonagem, não é idêntica à prática $\mathrm{Y}$, permitir que um pobre ou que uma criança prematura nasça (para que fique claro: um dano físico, psicológico, econômico difere - e muito! - de um dano existencial-ontológico); nem muito menos se assemelha o que está em jogo em cada um dos casos: porque uma coisa é correr um risco inicialmente inesperado (como é o caso com o nascimento de crianças prematuras), outra completamente distinta é gerar deliberadamente uma criança à qual se causa conscientemente um dano (existencial).

\footnotetext{
${ }^{3} \mathrm{O}$ mais incrível na defesa desse argumento, por parte de Harris especificamente, se deve ao fato de que no mesmo livro, intitulado On Cloning, apenas algumas páginas adiante do primeiro argumento referido acima, ele defende exatamente o contrário do que parecia defender: uma vez que a vida da criança - diz ele - sempre "será uma vida totalmente digna, então não podem ser os interesses dessa criança as razões que justificam quaisquer decisões e regulações que a neguem as oportunidades de existência” (HARRIS, 2004, p. 76- 77), isto é, não faz sentido apelar para os interesses futuros da criança para negar existência a ela. Ficamos como alguém diante de um ladrão, sem saber se levanta ou não as mãos.
} 
Pois bem: além desse primeiro aspecto do cuidado criativo é preciso explicitar ainda o que o mesmo possui em estreita relação com a defesa do "argumento da variabilidade": a saber, o cuidado não busca apenas se resguardar do dano, ele também atende a uma lógica da alteridade ou ao que chamaremos de paradigma da adoção. Aqui, nosso princípio visa responder à questão das intenções em jogo na opção pela clonagem. Dentre os muitos motivos de recurso à clonagem, a defesa quanto à aplicação da técnica se concentra hoje em torno da solução de problemas relacionados a progenitores inférteis ou que por algum motivo não podem ter filhos. Não irei ater-me até onde se pode realmente defender uma defesa tão restrita da técnica - algo que me parece já um tanto problemático, pois fica a questão de como se pode separar com tanta segurança tais diferenças. Minha questão é outra. Pergunto: onde se encontra a razão de progenitores inférteis ou homossexuais, por exemplo, quanto à utilização da clonagem? A resposta dos defensores da clonagem é a de que os pais têm o direito a filhos que lhes sejam relacionados geneticamente.

Ora, é em resposta a esse segundo ponto que o princípio ético do cuidado criativo se mostra como possuindo um elemento mais positivo, isto é, como oferecendo um critério positivo do que deve ser feito pelos pais especialmente quanto à utilização de biotecnologias - em particular, a clonagem. Ora, tudo o que se afirma possui uma contrapartida, e a partir da contrapartida pode-se entender também o elemento positivo. É o que farei: partirei daquilo a que se opõe ao princípio do cuidado para entender o que ele ordena positivamente. Aqui, o que ele nos convida a pensar se desentende com um paradoxo flagrante da resposta dos defensores da clonagem, a saber: ao passo que se sugere ser "ingênuo pensar que o clone será como seu doador", defende-se, por outro lado, que não é ingênuo achar que a paternidade está relacionada ao sangue ou a uma herança genética unilateral (como é o caso do DNA mitocondrial, cuja única função, inclusive, é produzir energia). Mas está bem claro que na vontade de ter "filhos relacionados geneticamente" não se encontra implícito nada mais senão a verdadeira "falácia do determinismo genético", ou para expor de outra forma, a clonagem se quer contraditoriamente uma "solução à esterilidade severa [que] se inscreve assim na perspectiva de uma filiação sob condição genética, quer dizer, extremamente redutora sobre o plano simbólico" (FROGNEUX, 2001, p. 108). O paradoxo se torna ainda mais flagrante quando se percebe que dentre as possibilidades de solução para o problema da infertilidade, apenas duas parecem ter um resultado mais satisfatório do ponto de vista dos progenitores: o caso de progenitores homossexuais do sexo feminino e de progenitores heterossexuais em que a mulher é fértil e o homem é infértil. Nesses casos, em que o recurso a um doador de esperma foi recusado, o resultado é simplesmente idêntico: um dos progenitores não é, em termos de herança genética, propriamente 
pai biológico, mas apenas irmão de seu clone. Mesmo em relação à progenitora do óvulo é difícil saber até que ponto se pode chamá-la de mãe biológica. Para que fique claro: em ambos os casos - e note-se que estamos falando das duas melhores possibilidades - a clonagem implica necessariamente aquilo que chamarei, aqui, de o paradigma da adoção, isto é, a inserção da paternidade numa perspectiva não "redutora sobre o plano simbólico", ou se se preferir ainda, numa perspectiva onde ela não se aplica ao caso de reproduções "simbolicamente deficitárias" (cf. AUGÉ, 1999, p. 152).

É no sentido de superar tal déficit simbólico que o cuidado criativo tem antes como paradigma a adoção, e o que se afirma aí é o simples fato de que todo filho é adotado. Ao recusar toda orientação que se baseia numa lógica do mesmo, numa lógica refratária à alteridade, ou se se quiser ainda, numa crença pangenética ou mesmo na contemplação do umbigo genético, o cuidado criativo, ao privilegiar a adoção como paradigma, ensina que não é o sangue que conta, nem muito menos - descendo-se o labirinto biológico em escalas sempre menores - os genes, mas a philia. É ela que resguarda toda afiliação e paternidade. Há "filhos" que não são filhos, e aos quais os "pais (biológicos)" simplesmente deixam para traz: "filhos" não assumidos, deserdados.

Em especial, para se entender tudo o que está em jogo aqui, é preciso indicar o que o termo "criativo" significa em "cuidado criativo". Ele se opõe inicialmente a "procriativo" (por isso era necessário afastar qualquer tipo de parentesco com princípios como o de "autonomia procriativa" e "beneficência procriativa") - simplesmente não se trata de um princípio concernente à procriação, um fato puramente biológico. Nesse sentido, o termo "criativo" indica antes de tudo que, não o ato procriativo como tal em seus resultados, mas o paradigma da adoção é a essência da paternidade - termo que adotamos em sua acepção ampla (no sentido do inglês “parenting" antes que "fatherhood") -, pois a paternidade, bem salienta Marcel (1944, p. 136), “não é um puro dado de fato, ou... uma relação objetivamente determinável... seria completamente absurdo conceber a paternidade como um modo de causalidade, ou mesmo como uma finalidade”. Do mesmo modo que não é um evento biológico objetivo, a paternidade também não é um fato sociológico ou jurídico: não basta dar o nome a um filho e registrá-lo. Criativo também não se refere a um simples criar. Pai não é o que simplesmente cria. Uma das maiores características da sociedade contemporânea é a falência da paternidade, ou melhor: sua alienação, e isto justamente pela degeneração da paternidade ao mero criar. Aí o dispêndio de energia, próprio do que é criativo no cuidado, é simplesmente transferido para a escola, para a televisão, para a internet - e comprado pelo dinheiro, esta outra razão contemporânea para o não-ser-pai-e-mãe. Degenerada enquanto alienação, a paternidade não vai além de uma 
subpaternidade - para utilizar um termo mais correto e menos ambíguo do que o termo "hiperpaternidade [hyperparenting]" de Sandel (2007, p. 52).

Dessas últimas observações, gostaria de destacar, por fim, os dois elementos que caracterizam o que há de propriamente criativo no cuidar. Ele envolve, portanto, dispêndio de energia, engajamento e participação ativa - uma responsabilidade assumida e mantida. Mas só pode ser isto exatamente na medida em que abre espaço para a emergência de algo único e original - o filho que se realiza diante de nós, à medida que se cuida dele deixando-o ser o que ele autenticamente pode ser. Só aí, vemos por fim o que o cuidado criativo tem a ver com o princípio responsabilidade: a responsabilidade que exige a paternidade é uma responsabilidade não meramente biológica ou jurídica, mas é sobretudo a resposta a um apelo - na verdade, a um grito - de alteridade que não se realiza senão tendo a adoção como paradigma.

\section{REFERÊNCIAS BIBLIOGRÁFICAS}

ALLHOFF, F. 2004. Telomeres and the Ethics of Human Cloning. The American Journal of Bioethics $4(2)$ :

p. 29-31.

AUGÉ, Marc. 1999. Des individus sans filiation. In: ATLAN, Henry; AUGÉ, Marc; DELMASMARTY, M.; DROIT, R.-P.; FRESCO, N. (Eds.). Le Clonage Humain. Paris: Seuil.

BROCK, Dan W. 1998. Cloning Human Beings: An Assessment of the Ethical Issues Pro and Con. In: NUSSBAUM, Martha C. and SUNSTEIN, Cass R. (eds.). Clones and Clones: Facts and Fantasies about Human Cloning. New York: W. W. Norton, p. 141-67.

BUCHANAN, Allen et al. 2000. From Chance to Choice: genetics \& justice. New York: Cambridge University Press.

FROGNEUX, Nathalie. 2000. L'homme comme bouture de l'homme: quelques enjeux anthropologiques du clonage. Revue des Questions Scientifiques, 171, 1-2: p. 95-119.

GOFFI, Jean-Yves. 2007. The Harm of Being a Clone. In: FAGOT-LARGEAULT, Anne, RAHMAN, Shahid and TORRES, Juan Manuel (Eds.). The Influence of Genetics on Contemporary Thinking. Dordrecht, Springer, p. 151-163.

GRIFFIN, Harry. 2002. Cloning of Animals and Humans. In: BRYANT, John, LA VELLE, Linda Bargot and SEARLE, John (Eds.). Bioethics for Scientists. Chichester, UK: John Wiley \& Sons Ltd., p. 279-296.

HARRIS, John. 1997. "Goodbye Dolly?" The ethics of human cloning. Journal of Medical Ethics, 23, p. 353-360.

2004.

On Cloning. London:

Routledge.

2007. Enhancing Evolution: the ethical case for making

better people. Princeton, New Jersey: Princeton University Press. 
HOLM, Søren. 2001. A Life in the Shadow: One Reason Why We Should Not Clone Humans. In: KLOTZKO, Alerne Judith (Ed.). The Cloning Sourcebook. New York: Oxford New York, p. 203-207.

JONAS, Hans. 1966/2001. The Phenomenon of Life: Toward a Philosophical Biology. Evanston: Northwestern University Press.

. 1974/1980. Biological Engineering - A Preview. In: Philosophical Essays: From

Ancient Creed to Technological Man. Chicago: University of Chicago Press, 1980, p. 153-163. $569-582$. 1985/2004. Ethics and Biogenetic Art. Social Research, vol. 71, n 3, Fall 2004, p.

1985/1987. Technik, Medizin und Ethik: zur práxis des Prinzips Verantwortung. Frankfurt am Main: Suhrkamp.

1991. Erkenntnis und Verantwortung: Gespräch mit Ingo Hermann in der Reihe "Zeugen des Jahrhunderts“. Ingo Hermann (Hrsg.). Göttingen: Lamuv.

KAHN, Axel; PAPILLON, F. 1998. Copies conformes: le clonage en question. Paris: Nil Éditions.

KAHN, Axel. 2000. Clonage, filiation et alterité. In: Et l'Homme dans tout ça? Plaidoyer pour un humanisme moderne. Paris: Nil Éditions, p. 224-243.

KASS, Leon R. and WILSON, James Q. 1998. The Ethics of Human Cloning. Washington, DC: AEI Press.

KLOTZKO, Alerne Judith. 2007. Um Clone de si mesmo? A ciência e a ética da clonagem. Trad. Luciana Pudenzi. São Paulo: Loyola.

MARCEL, Gabriel. 1944. Homo Viator: Prolégomènes a une Métaphysique de L'Espérance. Paris: Aubier.

PENNISI, L. \& VOGEL, G. 2000. Clones: a hard act to follow. Science, 288, p. 1722-1727.

PRUSAK, Bernard G. 2008. Cloning and Corporeality. In: TIROSH-SAMUELSON, Hava \& WIESE, Christian (Ed.). The Legacy of Hans Jonas: Judaism and the Phenomenon of Life. Leiden - Boston: Brill, p. 315-344.

RENARD, J.-P. et al. 1999. Lymphoid Hypoplasia and Somatic Cloning. Lancet, 353, p. 14891491.

SANDEL, Michael. 2007. The Case against Perfection: Ethics in the Age of Genetic Engineering. Cambridge, MA: The Belknap Press of Harvard University Press.

SAVULESCU, Julian. 2001. Procreative Beneficence: Why We Should Select the Best Children. Bioethics, v. 15, issue 5-6, 2001, p. 413-426.

SINGER Peter. 2001. Cloning Humans and Cloning Animals. In: KLOTZKO, Alerne Judith (Ed.). The Cloning Sourcebook. New York: Oxford New York, p. 160-168.

SLOTERDIJK, Peter. 2000. La Domestication de L'Être: Pour un éclaircissement de la clairière. Traduction de l'allemand par Olivier Mannoni. Paris: Mille et une nuits. 
STEINBERG, Jesse R. 2005. Response to Fritz Allhoff, "Telomeres and the Ethics of Human Cloning" (AJOB 4:2). The American Journal of Bioethics 5(1): p. 27-28.

STEINBOCK, Bonnie. 2000. Cloning Human Beings: Sorting through the Ethical Issues. In: MACKINNON, Barbara (ed.) Human Cloning: Science, Ethics, and Public Policy. Urbana: University of Illinois Press, p. 68-84.

VALK, A. van der. 1997. Cloning as a Test Case of Autonomous Technology. Philosophy \& Technology 3: 1, p. 83-92. 